
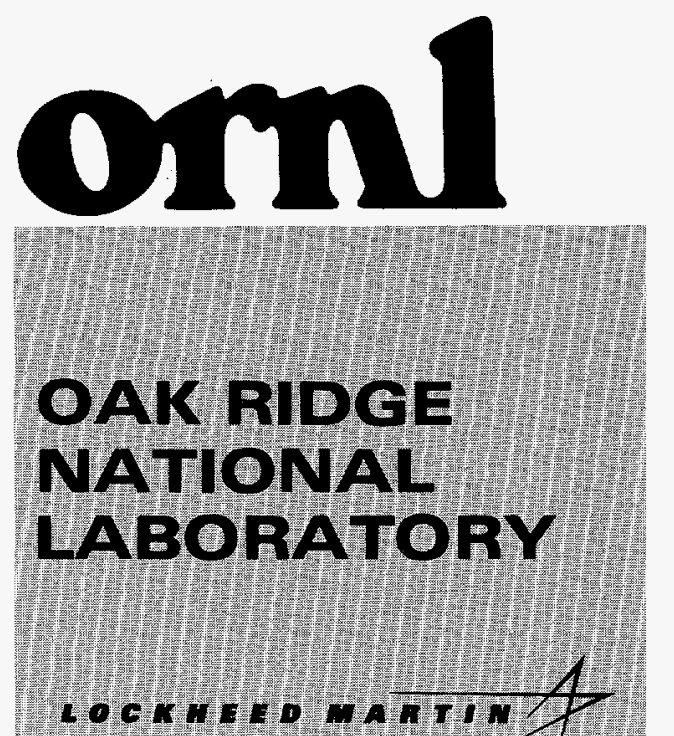

La

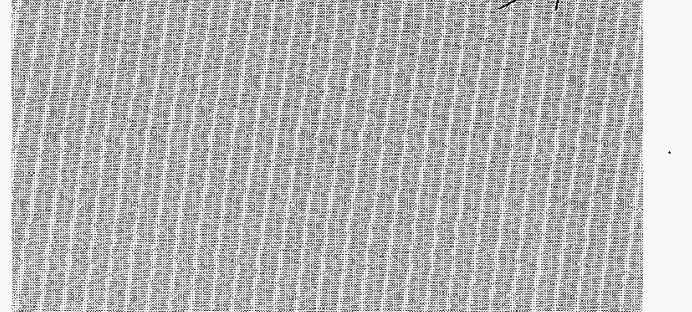


This report has been reproduced directly from the best available copy.

Available to DOE and DOE contractors from the Office of Scientific and Technical information, P.O. Box 62, Oak Ridge, TN 37831; prices available from (615) 576-8401, FTS 626-8401.

Available to the public trom the National Technical Information Service, U.S. Department of Commerce, 5285 Port Royal Rd., Springfield, VA 22161.

This report was prepared as an account of work sponsored by an agency of the United States Government. Neither the United States Government nor any agency thereof, nor any of their employees, makes any warranty, express or implied. or assumes any legal liability or responsibility for the accuracy, com pleteness, or usefuiness of any information, apparatus, product, or process disclosed, or represents that its use would not infringe privately owned rights. Reference herein to any specific commercial product, process, or service by trade name, trademark, manufecturer, or otherwise, does not necessarily constitute or imply its endorsement, recommendation, or favoring by the United States Government or any agency thereof. The views and opinions of authors expressed herein do not necessarily state or refiect those of the United States Government or any agency thereof. 


\section{DISCLAIMER}

Portions of this document may be illegible in electronic image products. Images are produced from the best available original document. 
ORNL/TM-13531

\title{
FIELD EVALUATION OF A HORIZONTAL WELL RECIRCULATION SYSTEM FOR GROUNDWATER TREATMENT: PILOT TEST AT THE CLEAN TEST SITE PORTSMOUTH GASEOUS DIFFUSION PLANT PIKETON, OHIO
}

\author{
Prepared by \\ M. T. Muck ${ }^{1}$, P. M. Kearl ${ }^{1}$, R. L. Siegrist ${ }^{2}$, N. E. Korte ${ }^{1}$, R. M. Schlosser ${ }^{1}$, \\ M. E. Mumby ${ }^{1}$, D. T. Davenport ${ }^{3}$, T. C. Houk ${ }^{3}$, D. W. Greene ${ }^{1}$, D. A. Pickering ${ }^{1}$, and \\ C. A. Muhr ${ }^{1}$
}

Managed by

LOCKHEED MARTIN ENERGY RESEARCH CORPORATION

for the

U.S. DEPARTMENT OF ENERGY

Under Contract \#DE-AC05-960R22464

This work is funded by the Office of Science and Technology

within the Department of Energy Office of Environmental Management, under the In Situ Remediation Integrated Program.

1 Lockheed Martin Energy Research Corp., Oak Ridge National Laboratory, Environmental Technology Section, Grand Junction, Colo., 81502

2 Lockheed Martin Energy Research Corp., Oak Ridge National Laboratory, Environmental Sciences Division, Oak Ridge, Tenn., 37830

3 Lockheed Martin Energy Systems, Portsmouth Gaseous Diffusion Plant, Piketon, Ohio, 45661 


\section{Contents}

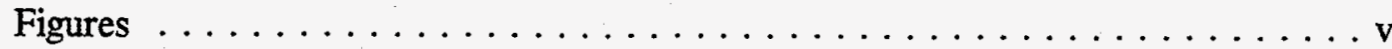

Tables ......................... vi

Abbreviations, Acronyms, and Initialisms $\ldots \ldots \ldots \ldots \ldots$ vii

Acknowledgment . . . . . . . . . . . . . . . . . . . ix

Executive Summary $\ldots \ldots \ldots \ldots \ldots \ldots \ldots \ldots \ldots \ldots \ldots \ldots$

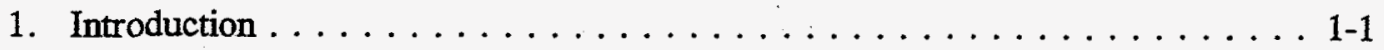

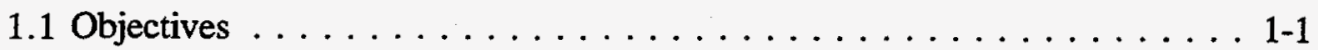

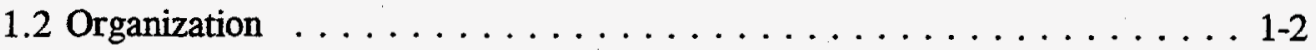

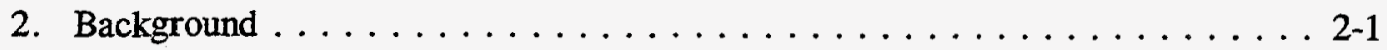

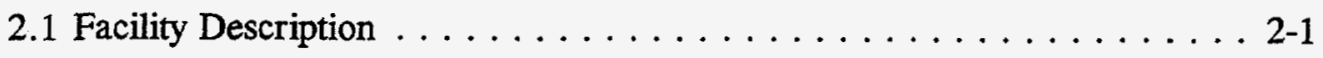

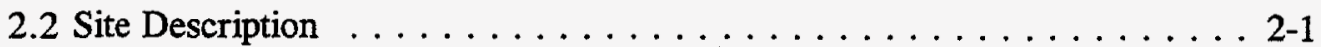

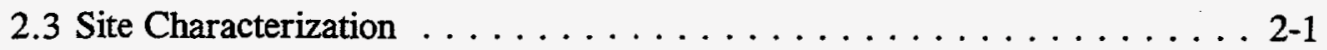

3. Horizontal Well Installation and Development $\ldots \ldots \ldots \ldots \ldots \ldots . \ldots .1$

3.1 Well Installation . . . . . . . . . . . . . . . . . . . 3-5

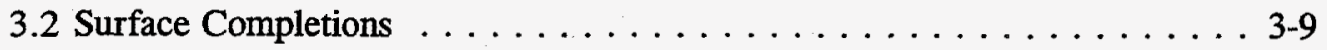

3.3 Initial Well Development $\ldots \ldots \ldots \ldots \ldots \ldots \ldots . . \ldots \ldots$

4. Piezometer Installation and Development $\ldots \ldots \ldots \ldots \ldots \ldots$ 4-1

5. Hydraulic Evaluation of the Horizontal Well Recirculation System . . . . . 5-1

5.1 Introduction $\ldots \ldots \ldots \ldots \ldots \ldots \ldots \ldots \ldots$. . . . . . . . . . . . . . .

5.2 Theoretical Development $\ldots \ldots \ldots \ldots \ldots \ldots \ldots \ldots \ldots$ 5-1

5.3 Piezometer Hydraulic Tests . . . . . . . . . . . . . . . . . . . 5-4

5.4 Horizontal Well Pumping Tests $\ldots \ldots \ldots \ldots \ldots \ldots \ldots$. . . . . . . .

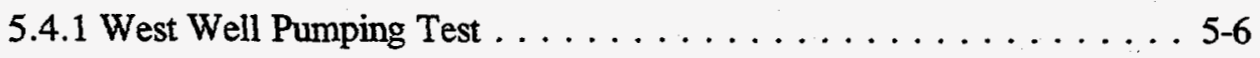

5.4 .2 East Well Pumping Test $\ldots \ldots \ldots \ldots \ldots \ldots \ldots \ldots . \ldots \ldots \ldots$

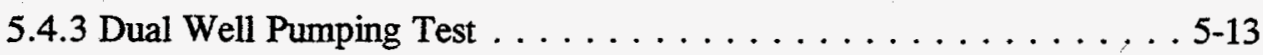

5.5 Well-Filter Efficiency $\ldots \ldots \ldots \ldots \ldots \ldots \ldots \ldots \ldots \ldots \ldots \ldots$

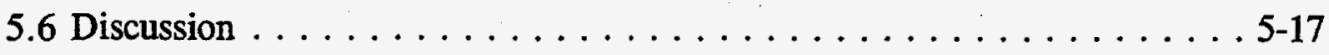

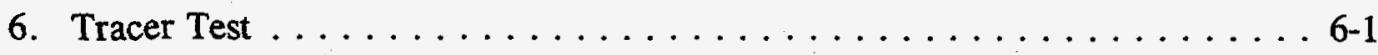

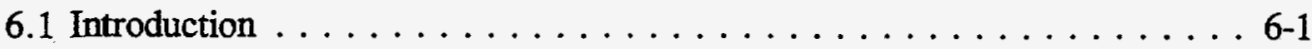

6.2 Description of the Bromide Tracer $\ldots \ldots \ldots \ldots \ldots \ldots$ 6-1 
6.3 Stock Tracer Concentration $\ldots \ldots \ldots \ldots \ldots \ldots \ldots$. . . . . . . . . . .

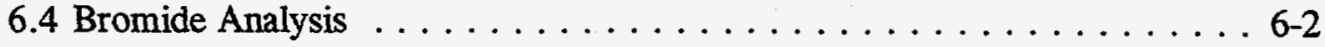

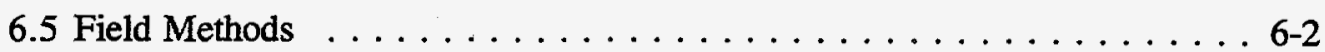

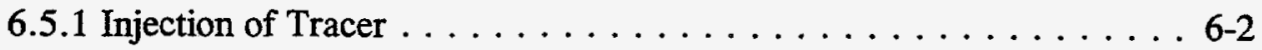

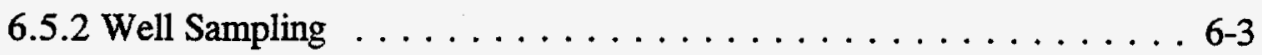

6.6 Horizontal Well Performance During Tracer Test $\ldots \ldots \ldots . . . .66-8$

6.7 Tracer Test Results . . . . . . . . . . . . . . . . . . 6 6-8

6.7.1 Horizontal Extraction Well Results . . . . . . . . . . . . . 6-9

6.7.2 Gallia Member Piezometer Results . . . . . . . . . . . . . . . . . 6-12

6.7.3 Minford Member Piezometer Results . . . . . . . . . . . . . . . . . 6-14

6.7.4 Test Results for the 2.5-cm-diameter Piezometers . . . . . . . . . . . 6-15

6.8 Colloidal Borescope Measurements . . . . . . . . . . . . 6-15

6.9 Discussion . . . . . . . . . . . . . . . . . . . 6-16

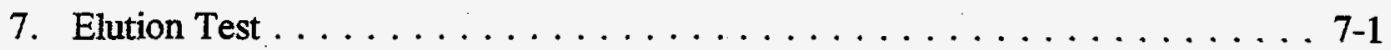

7.1 Introduction $\ldots \ldots \ldots \ldots \ldots \ldots \ldots \ldots \ldots \ldots \ldots \ldots \ldots \ldots \ldots \ldots$

7.2 Elution Test Results $\ldots \ldots \ldots \ldots \ldots \ldots \ldots \ldots \ldots$. . . . . . .

8. Development of the Horizontal Wells $\ldots \ldots \ldots \ldots \ldots \ldots . . . . . . . .68$

8.1 Introduction $\ldots \ldots \ldots \ldots \ldots \ldots \ldots \ldots \ldots \ldots$. 8

8.2 Field Program $\ldots \ldots \ldots \ldots \ldots \ldots \ldots \ldots \ldots . \ldots \ldots$ 8-1

8.3 Development Results $\ldots \ldots \ldots \ldots \ldots \ldots \ldots \ldots \ldots$. $\ldots \ldots \ldots$

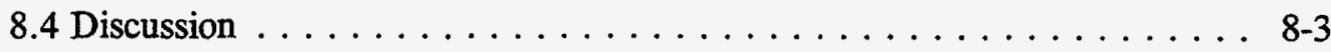

9. Conclusions $\ldots \ldots \ldots \ldots \ldots \ldots \ldots \ldots \ldots \ldots \ldots \ldots \ldots \ldots$ 9-1

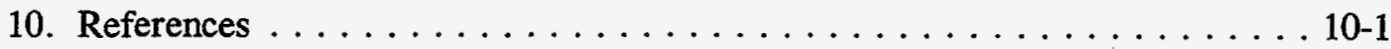

Appendix A Geologic Logs and Geotechnical Data for Boreholes at the Clean Test Site

Appendix B Vendor Information for Schumacher Porous Filters

Appendix C Geologic Logs and Completion Diagrams for Piezometers at the Clean Test Site

Appendix D Pressure Transducer Data from the West Well Pumping Test

Appendix E Pressure Transducer Data from the East Well Pumping Test

Appendix F Pressure Transducer Data from the Dual Well Horizontal Recirculation Test

Appendix G Groundwater Velocity Data Gathered by the Colloidal Borescope for Selected Piezometers 


\section{Figures}

2.1 Location of Portsmouth Gaseous Diffusion Plant. . . . . . . . . . . . . 2-2

2.2 Location of the Clean Test Site. . . . . . . . . . . . . . . 2-3

2.3 Topography of the Clean Test Site. . . . . . . . . . . . . . . . 2-4

2.4 Bedrock surface contour map for the Clean Test Site. . . . . . . . . . . . 2-6

2.5 Stratigraphic sequence of borehole number $7 . \ldots \ldots \ldots \ldots \ldots . \ldots . \ldots 2-7$

2.6 Geologic cross sections at the locations of the horizontal wells. . . . . . . 2-9

3.1 Locations of horizontal wells and piezometers. . . . . . . . . . . . 3-2

3.2 Cross sections of the horizontal wells. . . . . . . . . . . . . . . 3-3

3.3 Conceptual illustration of horizontal well drilling and installation . . . . . . 3-4

4.1 Baseline potentiometric surface map . . . . . . . . . . . . 4-3

5.1 Hydraulic conductivity values based on single-well tests and the distribution of $\mathrm{K}$ at the CTS . . . . . . . . . . . . . . . 5-5

5.2 Extent of drawdown in the Gallia resulting from pumping the west horizontal well for $24 \mathrm{~h} \ldots \ldots \ldots \ldots \ldots \ldots$. . . . . . . . . . .

5.3 Drawdown graphs for individual piezometers during the west well pumping test . . . . . . . . . . . . . . . . . .

5.4 Type curve for a line sink using PZ-08 drawdown data from the west well pumping test . . . . . . . . . . . . . . . . . . . . . . . . . 5-10

5.5 Drawdown graphs for individual piezometers during the east well

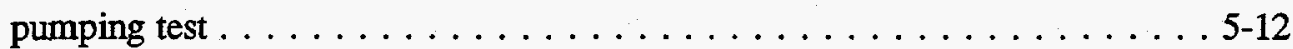

5.6 Extent of drawdown in the Gallia resulting from pumping the east horizontal well for $24 \mathrm{~h} \ldots \ldots \ldots \ldots \ldots \ldots$. . . . . . . . . . . . . .

5.7 Water-level changes in response to dual well horizontal recirculation . . . . 5-15

6.1 Locations of piezometers sampled during the horizontal recirculation tracer test $\ldots \ldots \ldots \ldots \ldots \ldots \ldots \ldots \ldots$. . . . . . . . . . . . . .

6.2 Bromide concentrations from the horizontal extraction well during the

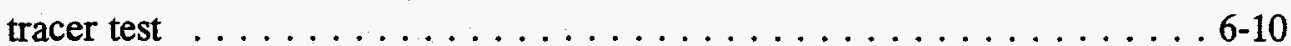

6.3 Bromide concentrations in the individual piezometers during the tracer test . . . . . . . . . . . . . . . . . . . . . 6-11

6.4 Extent of bromide breakthrough at selected time intervals . . . . . . . . 6-13

7.1 Bromide concentrations in individual piezometers during the elution test $\ldots$ 7-2

7.2 Bromide concentrations in the horizontal extraction well during the

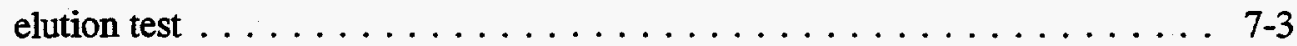

7.3 Bromide concentrations in the fire-hydrant water during the elution test . . . . 7-4

8.1 Comparison of the horizontal recirculation rate, pre- and postdevelopment 


\section{Tables}

2.1 Survey elevations of ground surface and bedrock surface at borehole locations. . . . . . . . . . . . . . . . . . . . . . 2-8

3.1 Task summary for drilling and installation of the horizontal wells. . . . . . 3-10

3.2 Water quality of development water from the horizontal wells. . . . . . . 3-11

4.1 Piezometer survey data and screened intervals . . . . . . . . . . . . . 4-1

6.1 Piezometer response to the bromide tracer test . . . . . . . . . . . 6-5

6.2 Pumping schedule during the horizontal recirculation tracer test . . . . . . . 6-8

6.3 Groundwater velocity measurements in selected piezometers using the colloidal borescope $\ldots \ldots \ldots \ldots$. . . . . . . . . . . . . . . .

7.1. Observations of bromide concentrations in piezometers during the

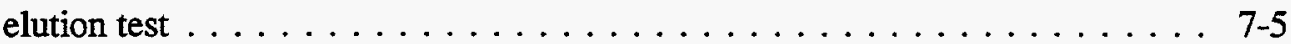




\section{Abbreviations, Acronyms, and Initialisms}

\begin{tabular}{|c|c|}
\hline amsl & above mean sea level \\
\hline bgs & below ground surface \\
\hline $\mathrm{BH}$ & borehole \\
\hline CE & construction engineer \\
\hline $\mathrm{cm}$ & centimeter \\
\hline CMSs & corrective measures studies \\
\hline CTS & Clean Test Site \\
\hline d & day \\
\hline DNAPL & dense nonaqueous-phase liquid \\
\hline DOE & U.S. Department of Energy \\
\hline ERWM & Environmental Restoration and Waste Management \\
\hline ETS & Environmental Technology Section \\
\hline $\mathrm{ft}$ & feet \\
\hline $\mathrm{g}$ & grams \\
\hline gal & gallons \\
\hline h & hour \\
\hline HDPE & high density polyethylene \\
\hline HSO & health and safety officer \\
\hline ID & inside diameter \\
\hline in & inch \\
\hline $\mathrm{K}$ & hydraulic conductivity \\
\hline $\mathrm{kg}$ & kilograms \\
\hline $\mathrm{L}$ & liter \\
\hline $\mathrm{lb}$ & pound \\
\hline $\mathrm{m}$ & meter \\
\hline$\mu \mathrm{g}$ & micrograms \\
\hline$\mu \mathrm{m}$ & micron \\
\hline $\min$ & minute(s) \\
\hline $\mathrm{mL}$ & milliliter \\
\hline $\mathrm{mV}$ & millivolt \\
\hline . & nanogram \\
\hline NTU & nephelometric turbidity unit \\
\hline$O D$ & outside diameter \\
\hline ORNL & Oak Ridge National Laboratory \\
\hline PORTS & Portsmouth Gaseous Diffusion Plant \\
\hline
\end{tabular}


psi

PZ

PVC

$s$

TCE

U.S.

vs

yd

pounds per square inch

piezometer

polyvinyl chloride

second

trichloroethene

United States

versus

yard 


\section{Acknowledgment}

Identifying, testing, and implementing innovative technologies will be required in order to meet the expectations identified in the Ten Year Plan. The Portsmouth Gaseous Diffusion Plant (PORTS) has hosted and funded many technology demonstrations. The cooperative working relationship with the regulator community, a history of successfully moving from the demonstration stage to remediation of an existing unit, and the available technical support have combined to make PORTS an ideal site for field demonstrating new ideas.

Many individuals and organizations have contributed to the successful completion of this project. Without the financial support and management assistance of the U.S. Department of Energy (DOE) Office of Environmental Restoration and Lockheed Martin Energy Systems (LMES) at PORTS, this project could not have been accomplished. The project team is grateful to the following PORTS individuals for their support to the project:

$\begin{array}{lll}\text { E. Gillespie } & - & \text { DOE } \\ \text { J. Sheppard } & - & \text { DOE } \\ \text { L. Kantner } & - & \text { DOE } \\ \text { D. Taylor } & - & \text { LMES } \\ \text { R. Barnett } & - & \text { LMES (In Memorium) } \\ \text { D. Igou } & - & \text { LMES } \\ \text { T. Houk } & - & \text { LMES } \\ \text { J. Ervin } & - & \text { LMES } \\ \text { G. Budzin } & - & \text { LMES } \\ \text { B. Abke } & - & \text { LMES } \\ \text { H. Sydnor } & - & \text { LMES } \\ \text { P. Burleson } & - & \text { LMES } \\ \text { M. Pelfrey } & - & \text { Lockheed Martin Utility Services }\end{array}$




\section{Executive Summary}

This report presents the results of field testing a horizontal well recirculation system at the Portsmouth Gaseous Diffusion Plant (PORTS). The recirculation system uses a pair of horizontal wells, one for groundwater extraction and treatment and the other for reinjection of treated groundwater, to set up a recirculation flow field. The induced flow field from the injection well to the extraction well establishes a sweeping action for the removal and treatment of groundwater contaminants. The overall purpose of this project is to study treatment of mixed groundwater contaminants that occur in a thin water-bearing zone not easily targeted by traditional vertical wells. The project involves several research elements, including treatment-process evaluation, hydrodynamic flow and transport modeling, pilot testing at an uncontaminated site, and pilot testing at a contaminated site. The results of the pilot test at an uncontaminated site, the Clean Test Site (CTS), are presented in this report.

Two horizontal wells were installed in October 1994 at the CTS to test the horizontal recirculation concept. The wells, with horizontal sections $70 \mathrm{~m}(230 \mathrm{ft})$ long, were installed at a depth of $9 \mathrm{~m}$ (30 ft) using a directional drilling rig. The wells were placed along the bedrock surface beneath a 0.6 to $2 \mathrm{~m}$ ( 2 to $6 \mathrm{ft}$ ) thick zone of moderately permeable, unconsolidated fluvial deposits. The horizontal sections were constructed with ductile porous filter, an innovative well material produced in Germany by Schumacher Umwelt- und Trenntechnik GmbH. This was the first installation and testing of this well filter material in the United States. The well filters have a pore size of $300 \mu \mathrm{m}$ and are composed of cintered spheres of high density polyethylene. Drilling and installation of the wells were completed in six days. A network of piezometers was also installed to assess the hydraulic influence of the horizontal well recirculation system on the surrounding groundwater flow field.

Hydraulic tests of well performance showed that a hydraulic gradient of 0.15 could be induced between the wells, an increase of two orders of magnitude over the preexisting gradient. A bromide tracer test showed that the entire flow field between the wells was affected by the recirculation system, with bromide transport dominated by advection in higher-permeability areas and by diffusion in lower-permeability areas. A follow-on elution test provided removal of approximately $77 \%$ of the injected bromide mass during a period of 20 days. The tracer test and elution test results indicate that the horizontal well recirculation system shows great promise for application at a contaminated site.

Clogging of the extraction well filter during the tracer test and elution test resulted in deterioration of well performance. It was determined that the method of well development recommended by the filter manufacturer, low rate pumping, was inadequate. During the fall of 1995 , the horizontal wells were developed by a more aggressive method that included water jetting and overpumping. Hydraulic tests conducted immediately after well development showed markedly improved well performance. During the fall of 1996, a 60day recirculation test was performed with no evidence of clogging. These results indicate that water jetting and overpumping are the proper methods for developing wells constructed with the ductile porous filter. 
Additional work at PORTS includes testing of the horizontal well recirculation system at a contaminated site, the results of which will be covered in a separate report. The project was jointly funded by the U.S. Department of Energy (DOE) EM-50, Office of Science and Technology, Subsurface Contaminants Focus Area, and by DOE EM-40 through PORTS. 


\section{Introduction}

This report presents the results from field tests of a horizontal well recirculation system at the Clean Test Site (CTS) of the Portsmouth Gaseous Diffusion Plant (PORTS), Piketon, Ohio. The field work for this project included the following tasks: (1) characterization of the geology of the CTS, (2) installation of two horizontal wells and 22 piezometers at the CTS, (3) hydrodynamic testing of the horizontal wells and piezometers, and (4) evaluation of the horizontal well recirculation system using pumping tests, tracer tests, and an elution test.

Horizontal wells are a component of the recirculation remedial technology being developed by Oak Ridge National Laboratory (ORNL). The installation and testing of a recirculation treatment system is one phase of a research and development project entitled "In Situ Treatment of Mixed Contaminants in Groundwater (OR141002)". This project is jointly funded by the U.S. Department of Energy (DOE) Office of Technology Development and PORTS Environmental Restoration and Waste Management (ERWM). The overall purpose of this three-year project is to study in situ treatment of mixed contaminants in groundwater using recirculation-well networks coupled with treatment modules. The mixed contaminants are volatile organic compounds such as trichloroethene (TCE) and radionuclides such as technetium. The project began in October 1993 and involves several key research elements, including treatment-process evaluation and screening, hydrodynamic flow and transport modeling, bench- and pilot-scale experimentation, and full-scale field demonstration at a DOE site (ORNL 1994).

PORTS ERWM is performing corrective measures studies (CMSs) to evaluate clean-up technologies for groundwater contamination at PORTS. This project will support those CMSs that address TCE and technetium contamination in groundwater by providing information on several groundwater treatment processes and by providing information necessary to evaluate the feasibility of using a horizontal well recirculation system for treatment of groundwater contamination at PORTS.

The CTS at PORTS was chosen as an appropriate location for determining the feasibility of installing and operating a recirculation treatment system. Upon successful testing of the system (successful installation, development, and hydrodynamic operation of the horizontal wells and recirculation system at a useful rate), a follow-on project is planned to demonstrate the use of a recirculation treatment system at a PORTS location with contaminated groundwater.

\subsection{Objectives}

Objectives for the evaluation of a recirculation treatment system at the CTS are as follows:

- Demonstrate innovative or alternative methods of installing horizontal wells;

- Determine the accuracy (depth control and lateral control) with which horizontal wells can be placed in a shallow, thin aquifer system; 
- Determine achievable pumping rates and aquifer hydrodynamics associated with a horizontal well recirculation system at the CTS.

\subsection{Organization}

The remainder of this report is organized as follows:

- Section 2 describes the CTS and results of the site characterization.

- Section 3 describes the horizontal well installation and initial development by pumping.

- Section 4 describes the piezometer installation and development.

- Section 5 describes the results of hydrodynamic tests of the piezometers and wells.

- Section 6 describes the results of tracer tests of the recirculation flow field.

- Section 7 describes the results of a bromide-elution test.

- Section 8 describes the use of a water-jetting development method to develop the horizontal wells and improve their performance.

- Section 9 presents conclusions from the results of the field work and lessons learned. 


\section{Background}

\subsection{Facility Description}

PORTS is a federal facility owned by DOE. The plant is operated by Lockheed Martin Utility Services under a contract with the United States Enrichment Corporation, a government-owned corporation. Lockheed Martin Energy Systems performs ERWM activities as well as the site management required by DOE. The $15.75 \mathrm{~km}^{2}(3,892$ acre $)$ federal reservation lies in Pike County, Ohio, between the cities of Chillicothe and Portsmouth and is approximately $113 \mathrm{~km}$ (70 miles) south of Columbus, Ohio (Fig. 2.1).

PORTS has been in operation since 1954 and is used to enrich uranium for commercial nuclear reactors. The PORTS process uses molecular diffusion techniques to separate the ${ }^{235} \mathrm{U}$ isotope from the ${ }^{238} \mathrm{U}$ isotope. PORTS consists of a complex cascade of compressors and convertors through which gaseous uranium hexafluoride feed is processed. The plant has an extensive support complex that consists of machine shops, laboratories, utilities, and decontamination facilities. As a result of plant operations, PORTS generates a wide variety of wastes, including low-level radioactive wastes, spent solvents, polychlorinated biphenylcontaminated oils, electroplating wastes, paint wastes, metal sludges, acids, and caustics.

\subsection{Site Description}

The CTS is located northwest of the intersection of Hewes Street and Perimeter Road and east of the X-230K Holding Pond (Fig. 2.2). The topography of the CTS is relatively level, with a drainage area along the western boundary and a hill adjacent to the eastern boundary of the site (Fig. 2.3). The CTS lies outside of the security fence of the plant and is in an uncontaminated area.

\subsection{Site Characterization}

The ORNL Environmental Technology Section (ORNL/ETS) characterized the geology of the CTS during the spring and summer of 1994 by collecting soil samples with a hollow-stemauger drilling rig and a GeoProbe ${ }^{\mathrm{TM}}$ rig. The geologic data collected from this site characterization were used to guide the placement of the horizontal wells.

The soil above bedrock at the CTS is composed of unconsolidated Quaternary fluvial and lacustrine deposits. These deposits are characterized by 4.6 to $6.7 \mathrm{~m}$ (15 to $22 \mathrm{ft}$ ) of lowpermeability clays and silts known as the Minford member, which is underlain by 0.6 to $2 \mathrm{~m}$ ( 2 to $6 \mathrm{ft}$ ) of moderately permeable sandy gravels, gravelly sands, and silty sands known as the Gallia member. The bedrock underlying the Quaternary deposits is composed of Mississippian-age Sunbury shale and Berea sandstone and shale. The Sunbury is a very low permeability shale unit that underlies the Gallia at the site. 


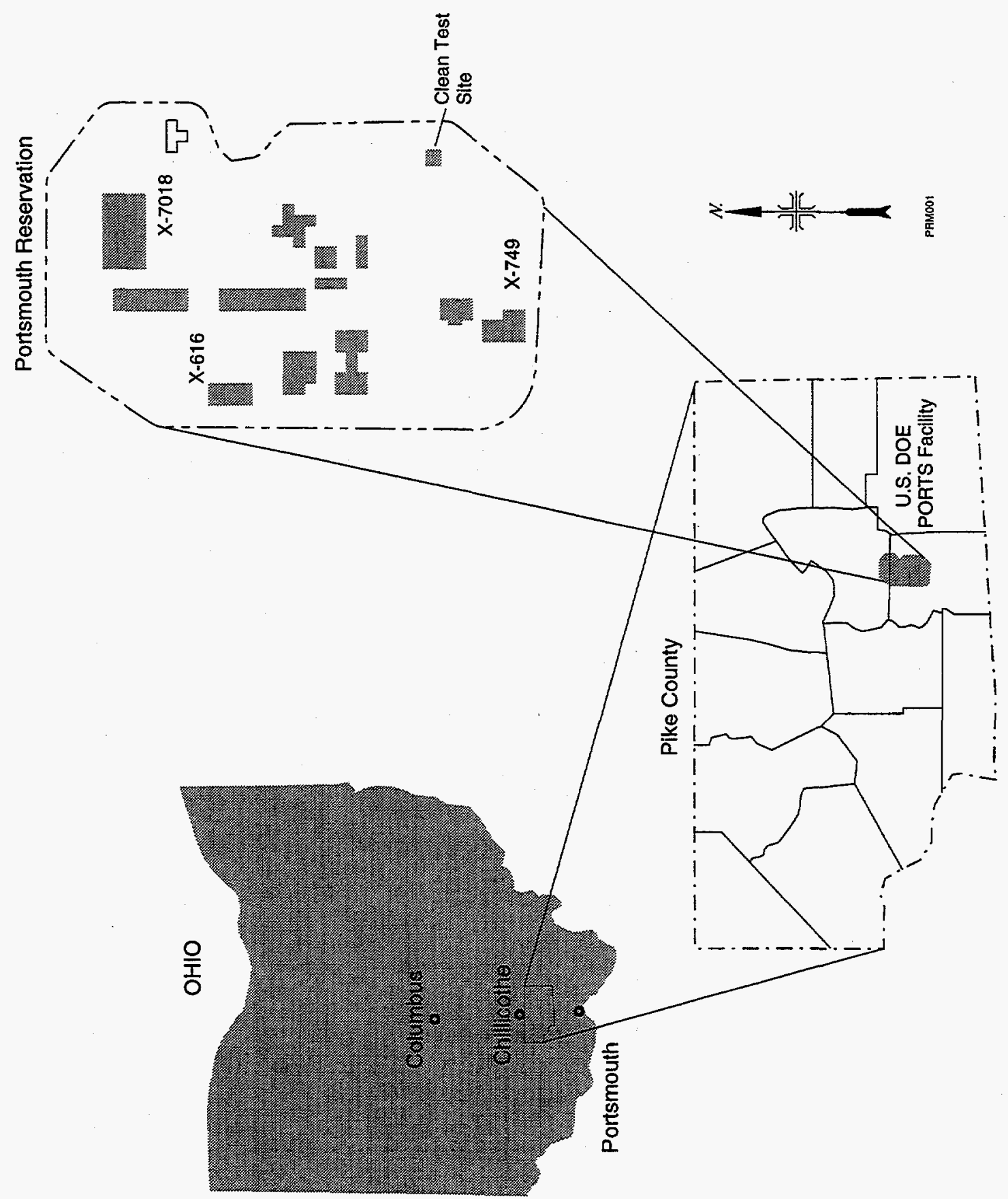

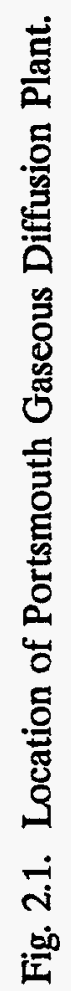



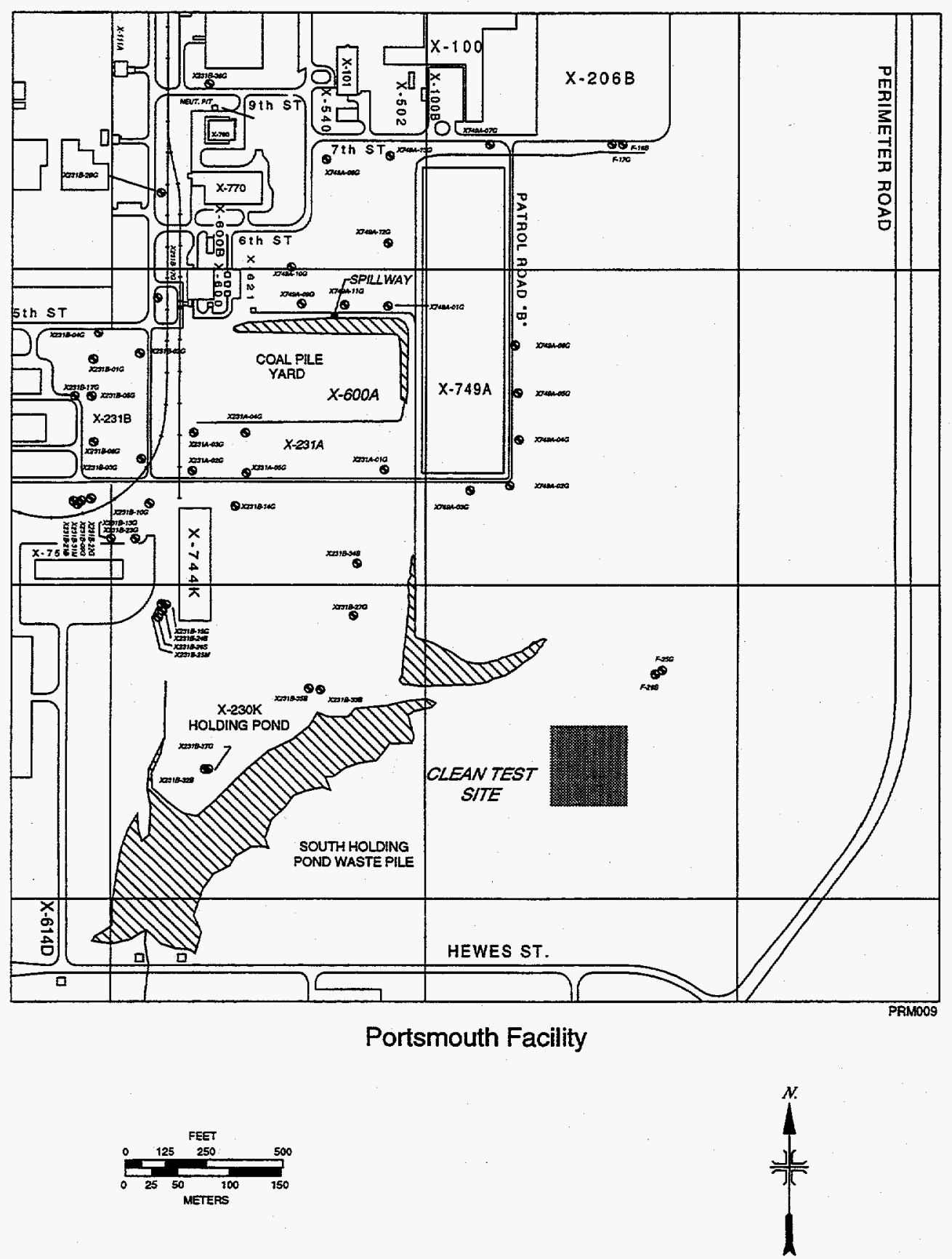

Fig. 2.2. Location of the Clean Test Site. 

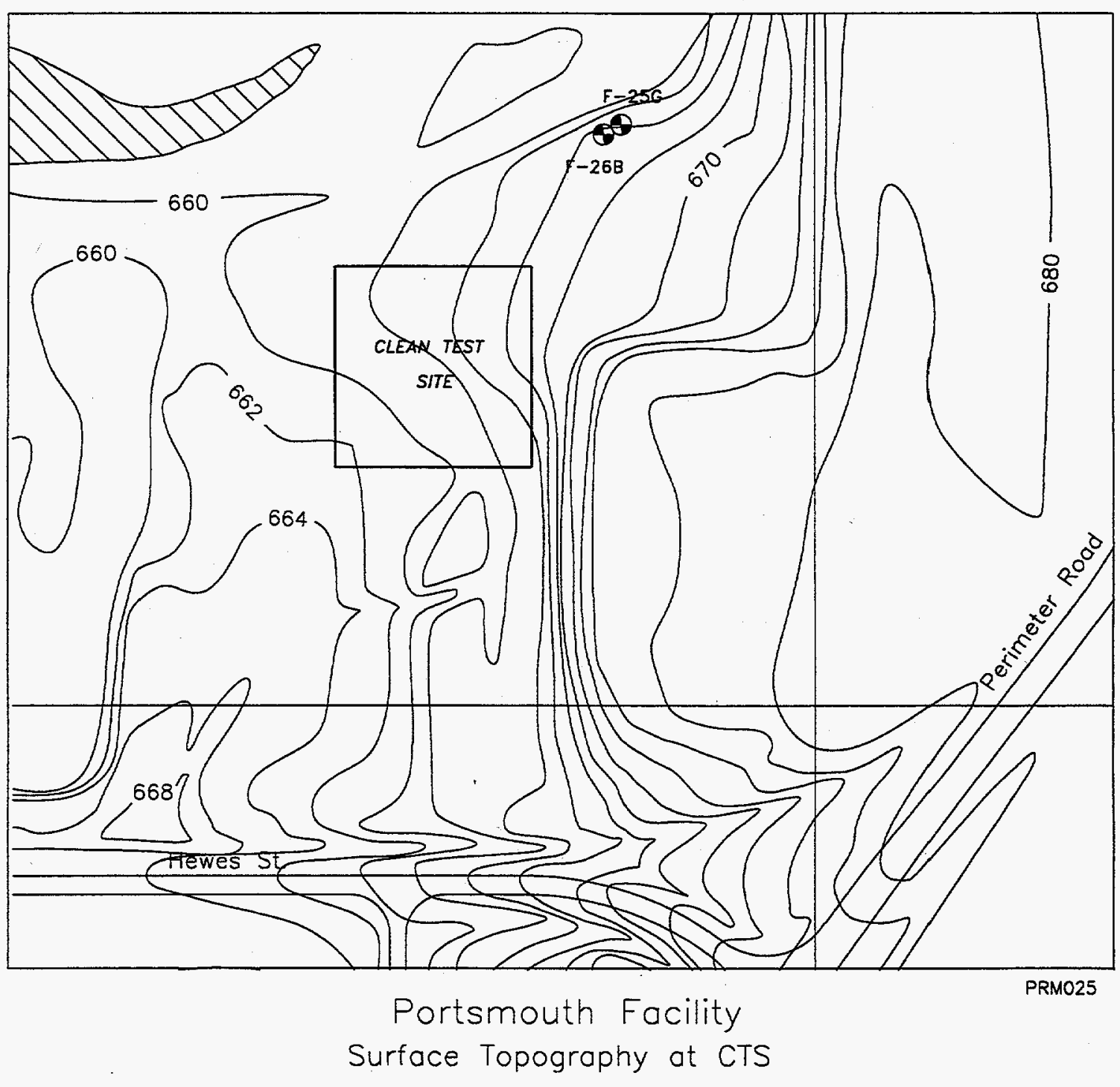

PRM025

FEET
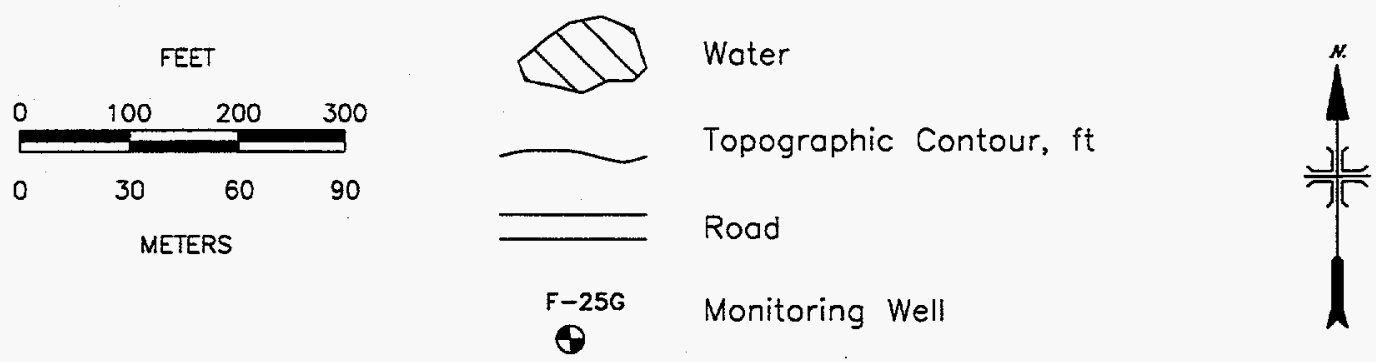

Source: PORTS ER/WM

Fig. 2.3. Topography of the Clean Test Site. 
The fenced area of the CTS is $73 \mathrm{~m}$ by $76 \mathrm{~m} \mathrm{(240} \mathrm{ft} \mathrm{by} 250 \mathrm{ft}$ ) (Fig. 2.2). During characterization nine boreholes were installed to bedrock at a depth of approximately $9 \mathrm{~m}$ $(30 \mathrm{ft})$. The borehole locations are numbered 1 through 9 in Fig. 2.4. Drilling was accomplished using an all-terrain CME 55 drill rig. The rig used 15.9-cm (6.25-in.) outside diameter (OD) by 8.3-cm (3.25-in.) inside diameter (ID) hollow-stem augers. A 7.6-cm (3-in.) diameter by $1.5-\mathrm{m}$ ( 5 - $\mathrm{ft}$ ) long CME continuous sampler was run a few centimeters ahead of the lead auger to obtain undisturbed soil samples for geologic logging. An average of three soil samples per hole were collected and analyzed for moisture content, liquid limit, plastic limit, and grain size. A detailed geologic log was prepared for each hole. Appendix A provides copies of the geologic logs and the results of the geotechnical analyses. As an example, Fig. 2.5 shows the stratigraphic sequence in borehole number 7 .

Water-level measurements taken during the drilling project indicated that groundwater in the Gallia and perhaps the lower portion of the Minford is confined by the overlying clays and silts. When the confined layers were penetrated by the augers, the groundwater level rose an average of $4.1 \mathrm{~m}(13.5 \mathrm{ft})$ above the depth at which saturated sediments were first encountered during drilling. Section 3 of this report presents a potentiometric-surface map based on water-level measurements from the network of piezometers.

The locations of the horizontal wells extend $137 \mathrm{~m}(450 \mathrm{ft})$ south of the fenced area of the CTS. During the summer of 1994, ORNL/ETS characterized the depth and thickness of the Gallia in the area of the horizontal wells. This was accomplished by collecting soil samples with a GeoProbe rig from six locations, numbered 10 through 15 in Fig. 2.4. The GeoProbe rig used a hydraulic ram to push a 2.5 -cm (1-in.) OD, hollow-steel rod into the subsurface. To collect soil samples, the GeoProbe rods were fitted with a drive point first or soil sample tube with drive point and pushed to the top of the sampling interval. Starting at a depth of approximately $4.6 \mathrm{~m}$ (15 ft) below ground surface (bgs), soil samples were collected continuously until the base of the Gallia was reached [at a depth of approximately $9.1 \mathrm{~m}$ $(30 \mathrm{ft})]$.

In the area of the horizontal wells, the Gallia is approximately 0.9 to $1.1 \mathrm{~m} \mathrm{(3}$ to $3.5 \mathrm{ft}$ ) thick. Table 2.1 provides the surveyed elevations of the ground surface and bedrock surface for the 15 soil boring and GeoProbe locations. Figure 2.4 is a bedrock contour map for the CTS (using bedrock surface elevations from Table 2.1 for the control points). Figure 2.6 shows cross sections of the geology at the locations of the horizontal wells. This geologic information was used to guide the placement of the horizontal wells along the bedrock surface. 

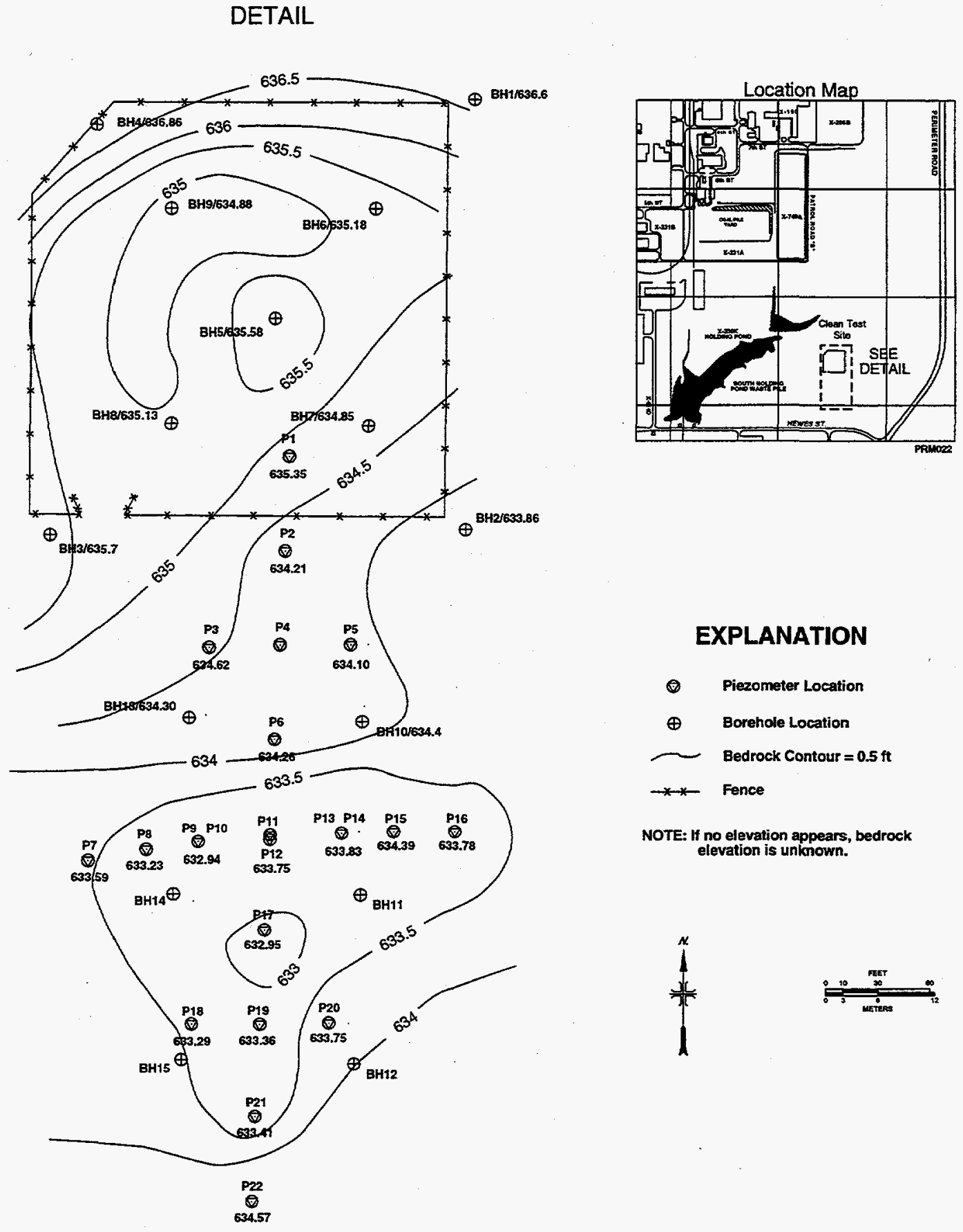

NOTE: If no elevation appears, bedrock elevation is unknown.
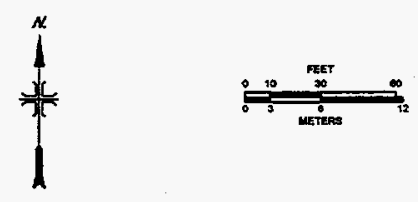

Fig. 2.4. Bedrock surface contour map for the Clean Test Site. 


\section{DEPTH $(\mathrm{ft})$}

0.5

8.5

22

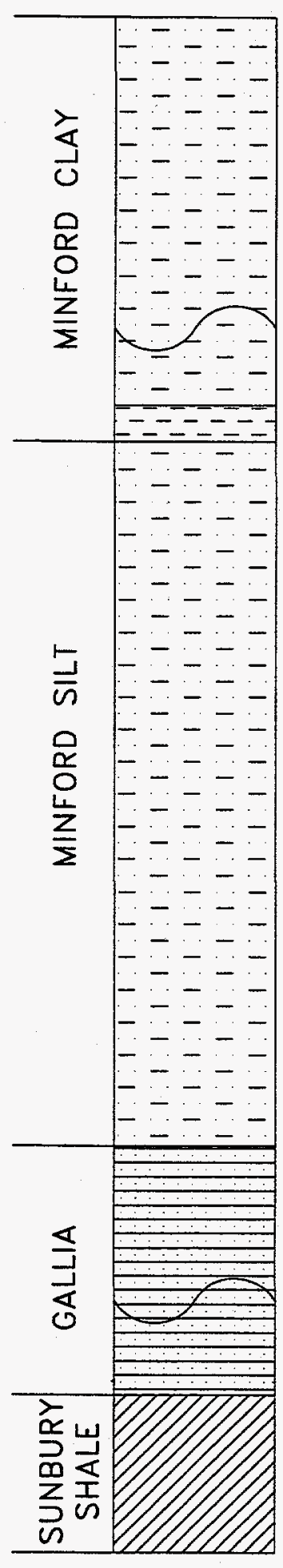

CL SILTY CLAY: yellowish brown (10YR 5/8) with gray mottling (10YR 5/1), firm, slightly moist, scattered organic staining.

CL SILTY CLAY: yellowish brown (1OYR 5/4) becoming light gray to gray (10YR $7 / 1-6 / 1)$, moist, firm.

CL CLAY: reddish brown (5YR 4/4), moist, dense, common MnO staining.

ML CLAYEY SILT: yellowish brown (10YR 6/6), moist, firm, sandy in part, angular sandstone pebble and gravels.

ML CLAYEY SILT: as above, grading to silty sand at $20^{\circ}$.

SM SILTY SAND: light olive brown (2.5Y 5/4) mottled with gray silt, fine grained, abundant limonite staining, moist, friable.

SM SILTY SAND: olive to olive yellow ( $5 Y 5 / 4-6 / 6$ ), moist, becoming wet with depth, angular pebbles.

SHALE: black carbonaceous.

Fig. 2.5. Stratigraphic sequence of borehole number 7 . 
Table 2.1. Survey elevations of ground surface and bedrock surface at borehole locations

\begin{tabular}{|c|c|c|c||}
\hline Borehole number & $\begin{array}{c}\text { Ground elevation, } \\
\text { ft amsl }\end{array}$ & $\begin{array}{c}\text { Depth to bedrock, } \\
\text { ft bgs }\end{array}$ & $\begin{array}{c}\text { Bedrock } \\
\text { elevation, } \\
\text { ft amsl }\end{array}$ \\
\hline 1 & 666.10 & 29.5 & 636.60 \\
\hline 2 & 662.36 & 28.5 & 633.86 \\
\hline 3 & 657.20 & 21.5 & 635.70 \\
\hline 4 & 661.32 & 24.5 & 636.86 \\
\hline 5 & 661.58 & 26.0 & 635.58 \\
\hline 6 & 664.88 & 29.7 & 635.18 \\
\hline 7 & 661.85 & 27.0 & 634.85 \\
\hline 8 & 659.13 & 24.0 & 635.13 \\
\hline 9 & 661.38 & 26.5 & 634.88 \\
\hline 10 & 662.70 & 28.3 & 634.40 \\
\hline 11 & 662.73 & 28.8 & 633.93 \\
\hline 12 & 663.07 & 29.1 & 633.97 \\
\hline 13 & 658.80 & 24.5 & 634.30 \\
\hline 14 & 658.12 & 24.5 & 633.62 \\
\hline 15 & 658.88 & 24.0 & 634.88 \\
\hline
\end{tabular}

amsl $=$ above mean sea level

bgs $=$ below ground surface 
Cross section Location Map
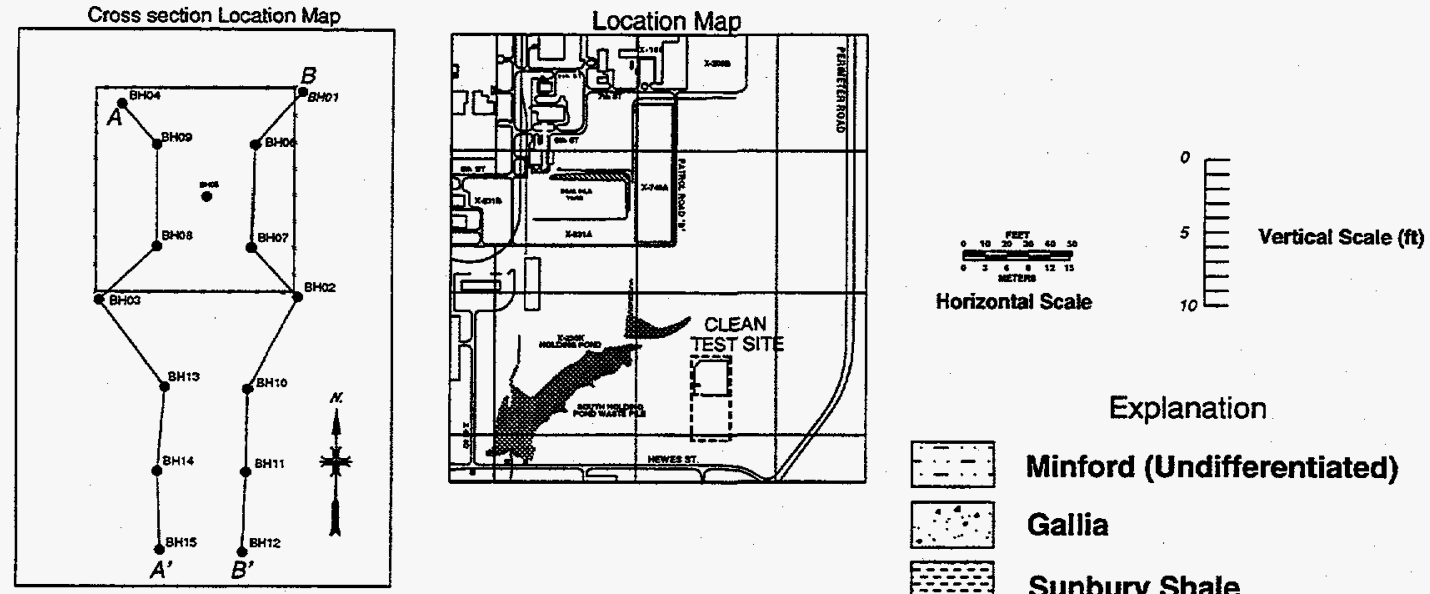

Explanation

--:- Minford (Undifferentiated)

$\because \because$ Gallia

Sunbury Shale

$A$

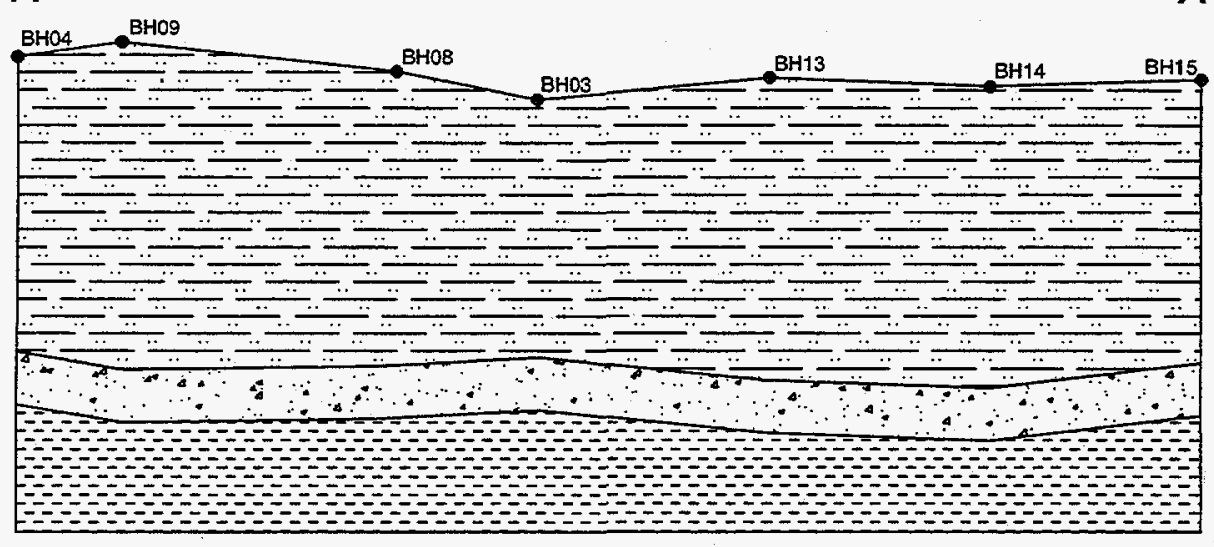

$B$

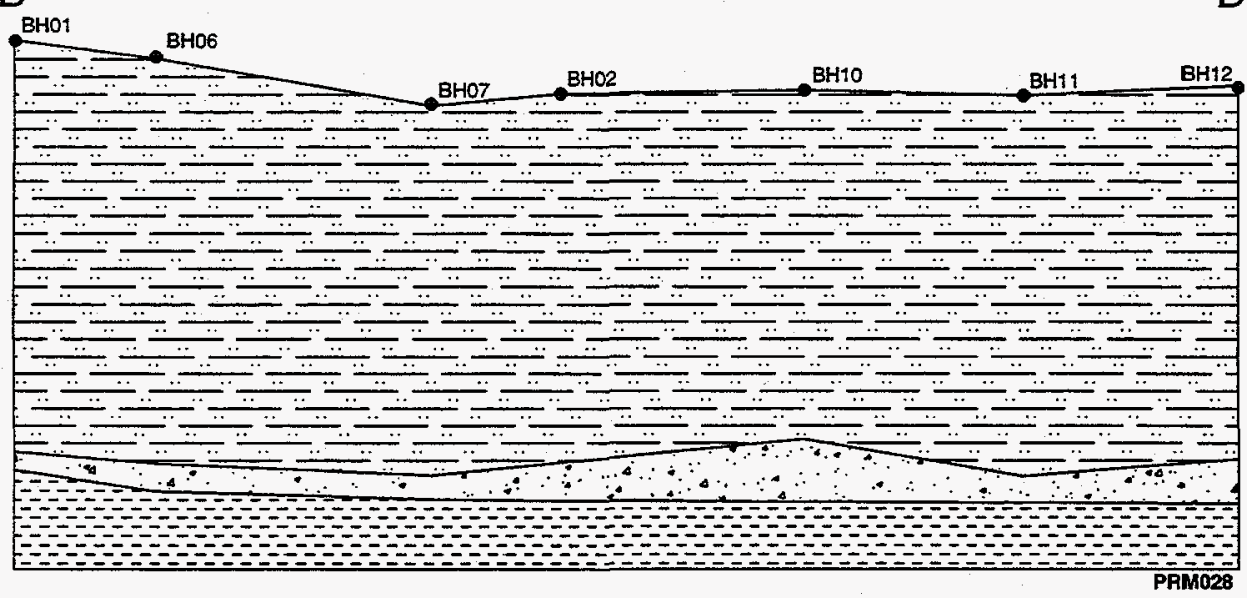

Fig. 2.6. Geologic cross sections at the locations of the horizontal wells. 


\section{Horizontal Well Installation and Development}

. Two horizontal wells were installed at the CTS from October 17 through October 22, 1994. Schumacher Filters America, Inc. (Schumacher America) provided the well installation service to ORNL/ETS through cooperation with FlowTex Technologie Import von Kabelverlegemaschinen GmbH (FlowTex), Schumacher Umwelt- und Trenntechnik GmbH (Schumacher), and Mears Engineering, Inc. (Mears). FlowTex directed the drilling and well installation and performed the drilling navigation, Schumacher provided porous filter materials for the wells, and Mears performed the drilling and well installation.

The horizontal wells were installed using a directional drilling rig. Because the Gallia is a thin formation, accurate control of the depth and direction of the drilling bit was essential. FlowTex used navigation equipment from Germany to provide a vertical accuracy of \pm 15 $\mathrm{cm}( \pm 0.5 \mathrm{ft})$ at a depth of $9.1 \mathrm{~m}(30 \mathrm{ft}) \mathrm{bgs}$. Each well was completed to land surface at both ends (Figs. 3.1 and 3.2). The horizontal sections are approximately $70 \mathrm{~m}$ (230 ft) long, and the slanted sections of pipe are approximately 37 to $40 \mathrm{~m}$ (120 to $130 \mathrm{ft}$ ) long (these sections were as short as practicable, dependent on the turning radius of the drilling equipment).

Each well was constructed with ductile high-density-polyethylene (HDPE) casing [13-cm (5-in.) ID] and ductile HDPE porous filter [7.6 cm (3-in.) ID with a fitting at each end to connect to the $13 \mathrm{~cm}$ (5-in.) ID casing]. The porous filter, used to construct the horizontal sections of the wells, is produced by Schumacher in Germany and is supplied in the U.S. by Schumacher America. As explained in Sect. 1, one of the objectives of this project was to test the performance of this innovative well filter material. Appendix B provides a description of this porous filter. No comparable product is known to be available from U.S. manufacturers, and there are no other distributors of the Schumacher filter in the U.S.

The casing materials came to the site in $12-\mathrm{m}(40-\mathrm{ft})$ lengths and the filter materials in $3.7-\mathrm{m}$ (12-ft) lengths. Prior to installation, the well materials were butt-fused together such that the porous filter was placed within the Gallia along the bedrock surface; the blank casing extended to ground surface from both ends of the filter. The wells were expected to provide a yield of $57 \mathrm{~L} / \mathrm{min}(15 \mathrm{gal} / \mathrm{min}$ ) or more (based on PORFLO modeling of the horizontal wells performed by ORNL), with low turbidity. A Schumacher filter pore size of $300 \mu \mathrm{m}$ (Appendix B) was selected to provide optimum water clarity, based on the results of filtration tests conducted by Schumacher using Gallia soil samples.

The drilling method included drilling a 22-cm (8.75-in.)-diameter guided pilot hole, picking up a 20-cm (8-in.)-diameter HDPE shelter casing at the exit hole and then pulling the shelter casing back into the hole with a 30-cm (12-in.)-diameter backreamer (Fig. 3.3). The casing and filter materials for the horizontal well were housed inside the shelter casing during installation. After the shelter casing and well materials were in place, the shelter casing was pulled from the borehole, and the borehole was allowed to collapse around the well materials. 


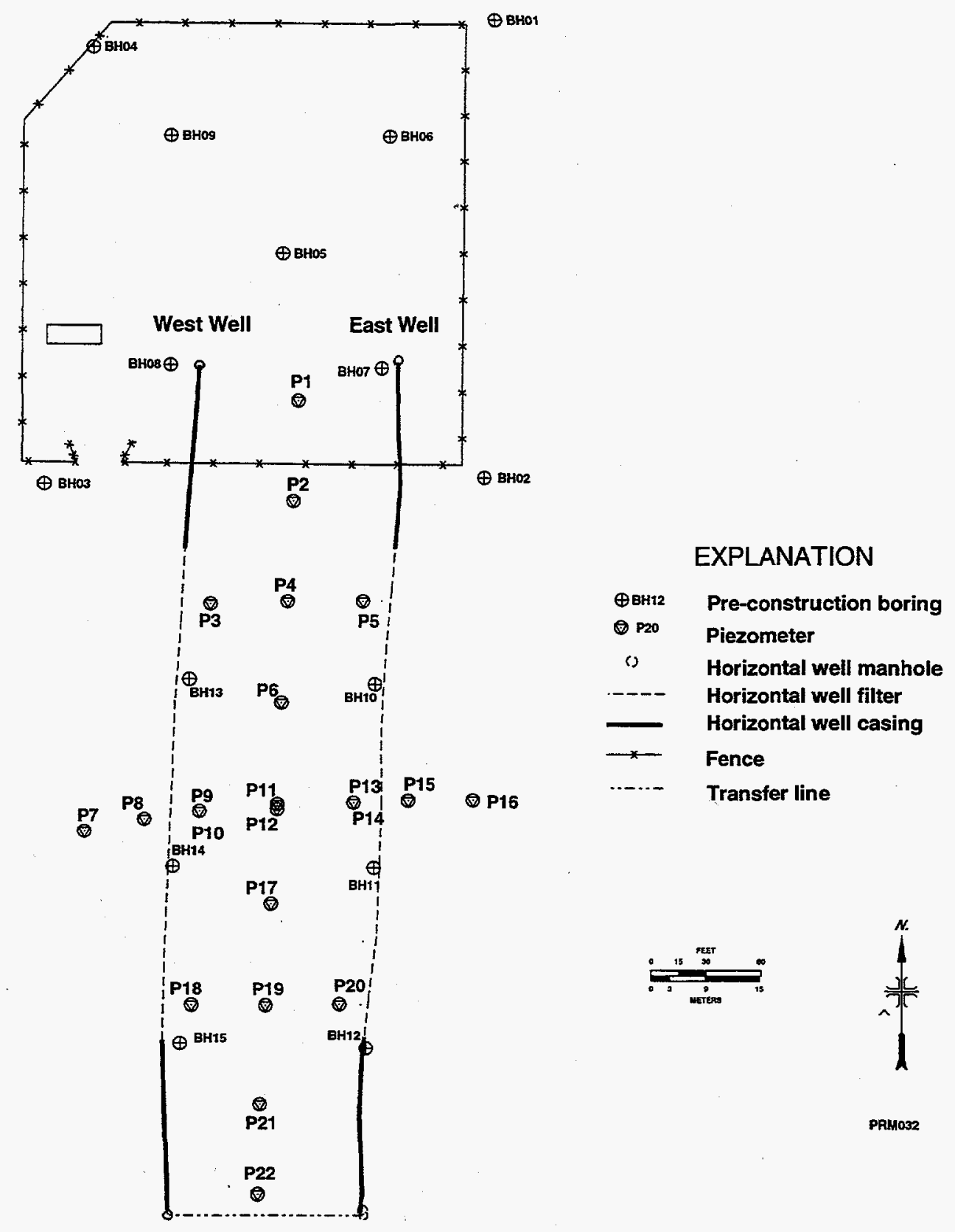

Fig. 3.1. Locations of horizontal wells and piezometers. 

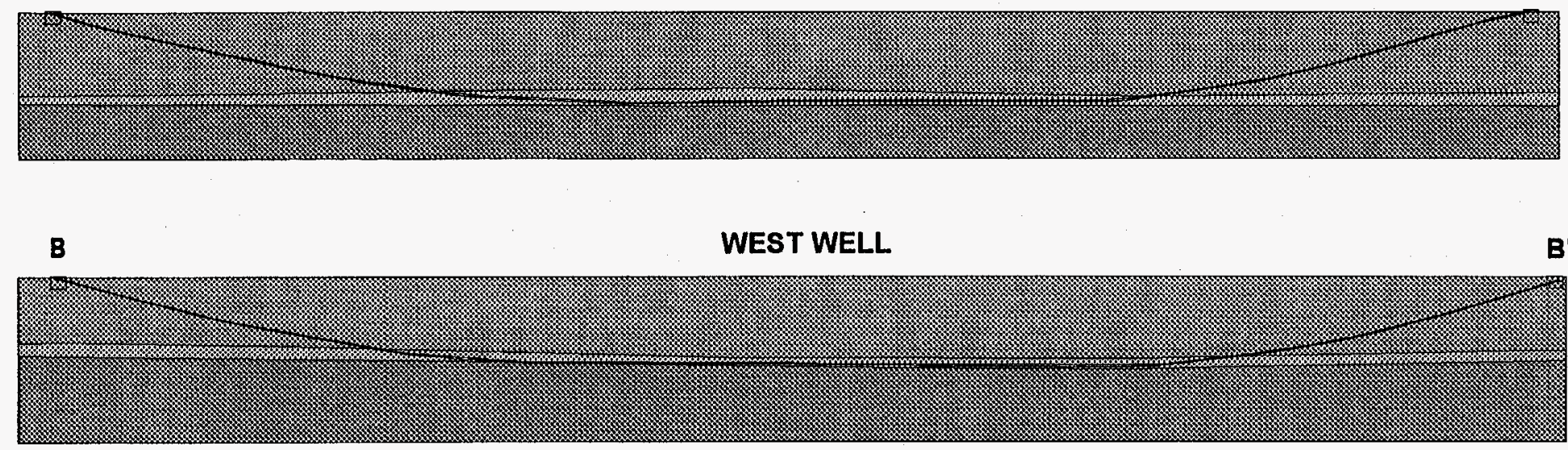

Minford (undifferentlated clays and silts)

Galla (sandy gravels, gravelly sands, silty sands)

Sunbury (shale)

13-cm $(6-1 \mathrm{n}$.$) HDPE pipe$

13-cm (6-in.) 300um (0.018-in.) Schumacher filter

$\square \quad 1.5-m(5-f t)-.d i a m e t e r$ manhole access

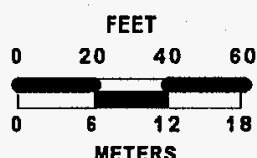

ORIZONTAL SCALE

$$
\begin{aligned}
& 40 \simeq{ }^{12} \\
& 30 \text { E }{ }^{12} \\
& \text { FeEt } 20=6 \text { METERS } \\
& 10 \text { E } 3 \\
& 0 \text { E } 0
\end{aligned}
$$

VERTIGAL SGALE

Fig. 3.2. Cross sections of the horizontal we11s. 

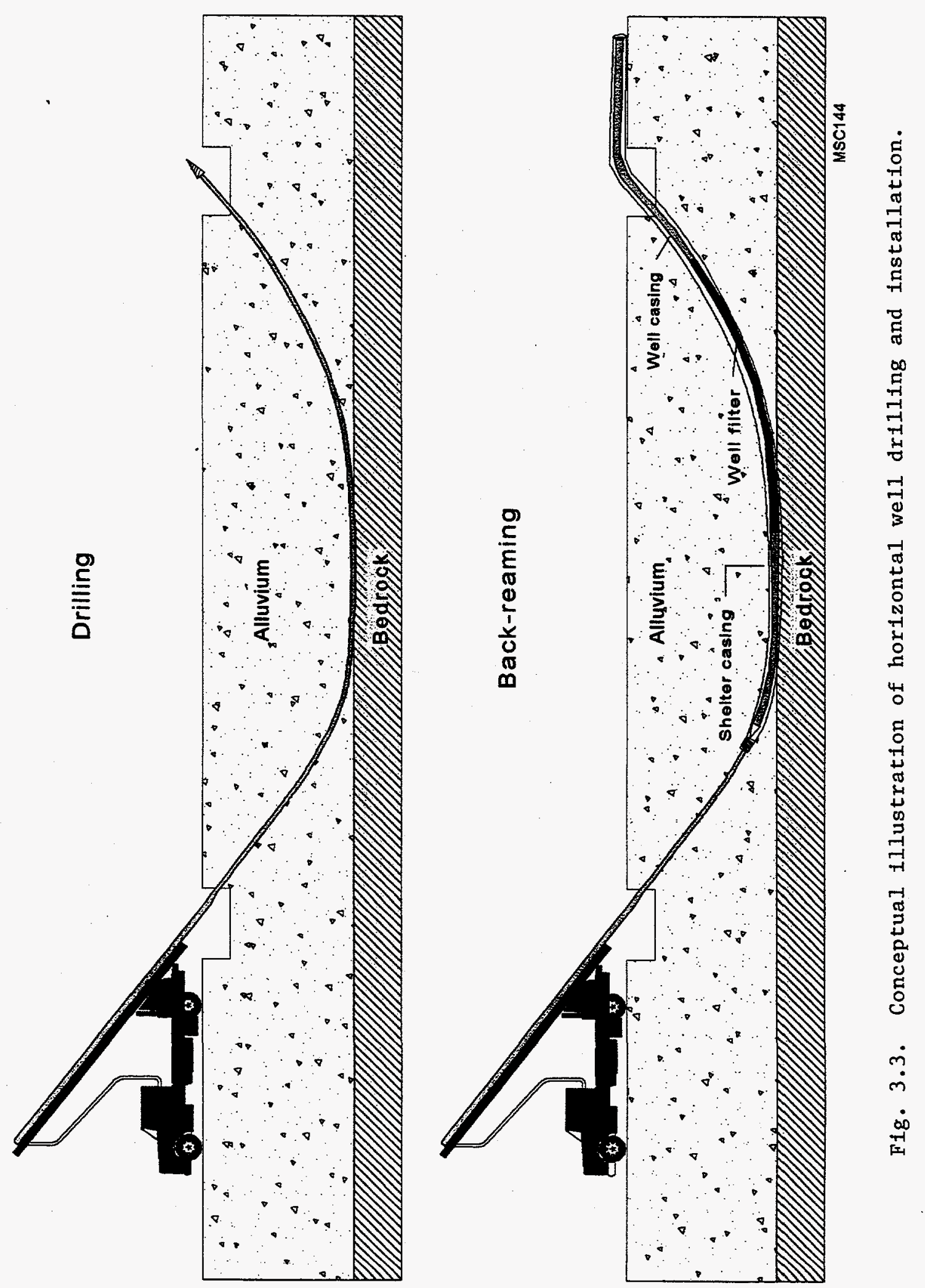
Drilling fluids, both water and drilling mud, were used to keep the borehole open during both drilling and installation of the shelter casing. Soil cuttings that were generated during drilling were handled according to PORTS waste management protocol under the direction of the PORTS construction engineer (CE). Because the CTS is an uncontaminated site, the cuttings were spread neatly around the drilling locations.

The axes of the horizontal wells are approximately $30 \mathrm{~m}(100 \mathrm{ft})$ apart and extend south of the fenced area of the CTS with an orientation that is approximately north-south (Fig. 3.1). These well locations were chosen out of convenience in parallel with the topographic contours of the area (Fig. 2.3). This orientation places the well heads in a fairly level area, which kept the drilling depth as constant as possible. The bedrock surface in this area slopes gently to the southeast (Fig. 2.4). An ORNL/ETS geologist worked closely with drilling personnel to direct the drilling depth and ensure that the wells were installed at the base of the Gallia. An ORNL/ETS health and safety officer (HSO) conducted health and safety meetings with the field crew at the start of each work day and provided health and safety oversight during field work.

\subsection{Well Installation}

Preparation for the drilling activities was conducted on the first day of field work. The Mears crew of seven and FlowTex crew of three mobilized equipment to the site and attended a tailgate health and safety meeting conducted by the ORNL HSO. Afterwards, ORNL personnel set up construction zones, and Mears personnel attended a health and safety orientation for the PORTS facility. After the orientation, PORTS health and safety and health physics representatives inspected the drilling rig and support equipment. Mears personnel set up the drilling equipment at the south end of the eastern horizontal well.

Two of the Mears workers heat welded the blank sections of 13-cm (5-in.) HDPE pipe. Four blank sections were constructed, each $37-\mathrm{m}$ (120-ft) long, by welding together three pieces of $12-\mathrm{m}(40-\mathrm{ft})$-long pipe. The heat welding was performed by lining up the ends of two pieces of pipe, squaring them off with a cutting tool, touching the ends to a heating iron until soft, and pressing the ends together at about 80 psi until cool. Each weld took approximately $30 \mathrm{~min}$ to complete, with all eight welds for the four sections of blank pipe completed during a 4-h period.

FlowTex personnel surveyed the ground surface along the drilling line for the east horizontal well and set up the navigation equipment for drilling. Navigation was conducted using a geomagnetic field induced by an electric cable that was laid in a loop around the length of the drilling line. The down-hole navigation assembly was attached behind the drill bit and consisted of a 9-m (30-ft) point of stainless-steel, 10-cm (4-in.)-diameter pipe that contained an inclinometer and magnetic survey tool.

Drilling of the eastern horizontal well began on the second day of field work. Mears personnel used a fire hose to fill the 11,355-L (3,000-gal) water tank on the support truck. This water was used to aid drilling operations. Four of the Mears personnel worked at the drilling rig: a driller, a crane operator, and two helpers to assist with the drill pipe. Two welders from Mears butt-fused together the porous filter for the eastern well. The filter was 
allowed to cure overnight before installation of the well materials. The Mears supervisor coordinated the drilling effort. FlowTex personnel included the project director, drilling supervisor, and navigation specialist. A backhoe operator from PORTS provided support to the drilling by digging the entrance hole and mud pits, removing excess mud from the pits, and maneuvering the well materials. The start pit and cuttings pit were each approximately $1.8 \mathrm{~m}$ by $1.5 \mathrm{~m}(6 \mathrm{ft}$ by $5 \mathrm{ft}$ ) and $1.2 \mathrm{~m}(4 \mathrm{ft})$ deep.

The pilot hole was drilled with a 22 -cm (8.75-in.)-diameter tricone bit. The down-hole navigation assembly was attached behind the drill bit. A tricone bit normally has a jet associated with each cone. Only one of the three mud jets on the bit was used during drilling to optimize vertical drilling accuracy. Adjustment of the drilling direction was accomplished by plugging two of the jets and then rotating the bit and cone with the remaining jet in the desired direction of borehole advancement. Initial drilling was accomplished using water as the drilling fluid. Approximately $4 \mathrm{~h}$ of drilling was necessary to reach the base of the Gallia

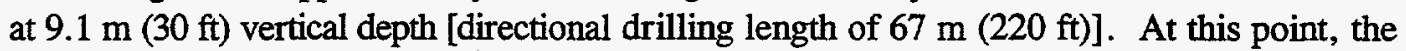
use of a biodegradable drilling mud began, and drilling proceeded horizontally along the base

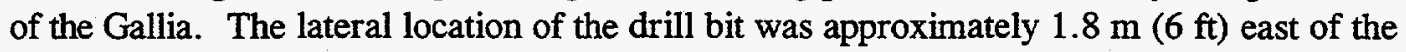
desired location; the lateral direction was corrected as the horizontal drilling proceeded. (The lateral drilling accuracy could have been improved by using all three jets, but the vertical drilling accuracy would not have been as good as with a single jet.)

The horizontal section of the pilot hole was drilled $15 \mathrm{~cm}(6 \mathrm{in}$.) above bedrock, so that when the shelter casing was installed with a larger diameter backreamer, the borehole from the backreamer would skim the bedrock surface. This would place the well materials along the bedrock surface when the shelter casing was removed.

The drilling mud was pumped at a rate of approximately $473 \mathrm{~L} / \mathrm{min}(125 \mathrm{gal} / \mathrm{min})$ with approximately $1.2 \mathrm{~kg} \mathrm{gel} / \mathrm{m}^{3}\left(2.1 \mathrm{lb} \mathrm{gel} / \mathrm{yd}^{3}\right)$ water. During the first $6 \mathrm{~h}$ of drilling, approximately $3785 \mathrm{~L}$ (1000 gal) of water was lost to the formation. The remaining water returned to the start pit and was run through a mud shaker and reused. The pumping rate was not high enough to allow good gravel returns to the surface. Returns from the Gallia were primarily fine- to medium-grained sands and associated fines (silts and clays). The slower pumping rate was used to provide better control over the lateral position of the borehole. Additionally, the drilling mud weight and viscosity were kept as low as possible to minimize the buildup of a filter cake on the borehole (a higher viscosity drilling mud could carry gravel to the surface with the lower pumping rate). Along the horizontal section, the cuttings in the drilling mud return were approximately $30 \%$ more than the borehole volume. This indicates that some washout (removal of formation materials adjacent to the borehole) occurred during drilling. At a drilling length of $85 \mathrm{~m}(280 \mathrm{ft})$, circulation was lost. The drilling mud density was increased to $3 \mathrm{~kg} / \mathrm{m}^{3}\left(5.1 \mathrm{lb} / \mathrm{yd}^{3}\right)$ to gain back circulation, and circulation of the drilling mud resumed.

At a drilling length of $98 \mathrm{~m}$ ( $320 \mathrm{ft})$, the drill bit was angled back toward ground surface. Lateral navigation of the drilling bit was difficult while angling up through the Gallia because as the bit angled up, it tended to veer toward the east, following the dip of the Gallia. The borehole was advanced into the Minford at a drilling length of approximately $102 \mathrm{~m}$ (335 ft). 
Drilling was completed for the day at a drilling length of approximately $119 \mathrm{~m}$ (390 ft). A total of approximately $15,140 \mathrm{~L}$ ( $4000 \mathrm{gal})$ of water were used during drilling for the day.

Installation of the eastern horizontal well was completed on the third day of field work. The remaining $24 \mathrm{~m}(80 \mathrm{ft})$ of the pilot hole were drilled in approximately $2 \mathrm{~h}$. The exit hole was

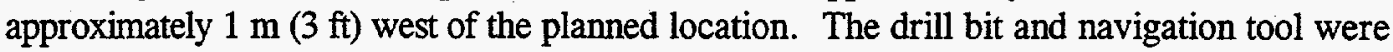
removed from the drill string at the exit hole and were replaced with a $30-\mathrm{cm}$ (12-in.)diameter backreamer.

The heat welders butt-fused together 12 lengths of 20 - $\mathrm{cm}$ (8-in.)-diameter by $12-\mathrm{m}(40-\mathrm{ft})$ long HDPE shelter casing. Each weld took approximately $20 \mathrm{~min}$ to complete, and the entire job of welding together the 146-m (480-ft)-long shelter casing took about $4 \mathrm{~h}$ to complete. The process of butt-fusing the lengths of HDPE leaves a bead inside the weld that is approximately one-half the wall thickness in height. Normally, an electric snake with a cutting tool is used to cut away the bead inside of the shelter casing. This allows the use of a smaller diameter shelter casing and, hence, a smaller diameter borehole. An electric snake was not available for this project. A $20-\mathrm{cm}$ (8-in.)-diameter shelter casing was selected to allow insertion of the well materials inside the shelter casing without trimming away the bead.

The welders butt-fused a section of 37-m (120-ft)-long, 13-cm (5-in.)-diameter HDPE pipe onto each end of the porous filter, and a line of workers (all of the available drilling personnel) assisted by inserting the completed string of well materials into the shelter casing. A small bulldozer dragged the shelter casing (with the housed well materials) into place behind the backreamer. A swivel was attached to the backreamer, and the shelter casing and well materials were attached to the swivel.

The backreamer was pulled back down the exit hole to the entrance hole while pulling the shelter casing into place. A mud pit [approximately $1.8 \mathrm{~m}$ by $3 \mathrm{~m}$ by $1.2 \mathrm{~m}(6 \mathrm{ft}$ by $10 \mathrm{ft}$ by $4 \mathrm{ft}$ ) deep] was installed at the exit hole to collect cutting returns from the exit hole during backreaming. A sump pump and hose were used to cycle the drilling mud back to the drilling rig, through the mud shaker, and back into the drill stem. Backreaming was accomplished by pulling and rotating the backreamer with a pump rate of $473 \mathrm{~L} / \mathrm{min}(125 \mathrm{gal} / \mathrm{min})$. Backreaming through the Minford (the slanted section of the borehole) proceeded at a rate of approximately $1 \mathrm{~m} / \mathrm{min}(3 \mathrm{ft} / \mathrm{min})$. Backreaming through the Gallia along the horizontal section of the borehole was at a slower rate. Return samples collected during backreaming showed a combination of Gallia gravel and Sunbury shale. This indicated the backreamer was running along the surface of the Sunbury, as desired. Installation of the 146-m ( $480-\mathrm{ft})$-long shelter casing was completed in approximately $5.5 \mathrm{~h}$. It is notable that there were no mud blowouts during drilling and installation of the eastern horizontal well. The total volume of drilling spoils produced during drilling and installation of the eastern well was approximately $20 \mathrm{~m}^{3}\left(720 \mathrm{ft}^{3}\right)$.

The south end of the well materials remained attached to the last piece of drilling rod (held to the rig) with a cap. A cover was placed over the north end of the well materials. The bulldozer dragged the shelter casing back out of the borehole, leaving the well materials in place. The entire shelter casing was removed in one piece in approximately $5 \mathrm{~min}$. The 
shelter casing was set aside for reuse during installation of the western horizontal well. For protections, plastic covers were placed over the ends of the eastern horizontal well.

During the morning of the fourth day of field work, the drilling equipment was moved $30 \mathrm{~m}$ $(100 \mathrm{ft})$ west to the south end of the western horizontal well. Equipment breakdown and setup took approximately $4 \mathrm{~h}$ to complete. As with the eastern well, drilling of the western well proceeded from the south end to the north.

Drilling began with three jets on the drill bit in an attempt to improve lateral accuracy. After $1 \mathrm{~h}$ of drilling, circulation was lost, and mud and water bubbled to the ground surface

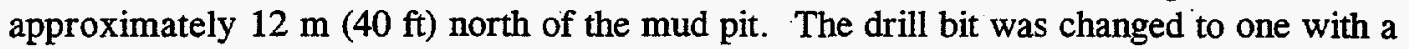
single jet for better vertical navigation. Drilling mud was pumped at a rate of $379 \mathrm{~L} / \mathrm{min}$ (100 $\mathrm{gal} / \mathrm{min}$ ) and a density of $2.5 \mathrm{~kg} / \mathrm{m}^{3}\left(4.2 \mathrm{lb} / \mathrm{yd}^{3}\right)$ to regain circulation. FlowTex noted that vertical accuracy could be controlled better by using a smaller diameter drill pipe commonly used in Europe. Additionally, penetration rates are higher with smaller-diameter drill pipe, and equivalent vertical control can be maintained.

After $5 \mathrm{~h}$ of drilling, the bit was angled along the base of the Gallia and horizontal drilling began. The cuttings returned to the surface contained approximately $90 \%$ Gallia sand and $10 \%$ Sunbury shale, indicating that drilling was proceeding along the contact of the Gallia and Sunbury, as desired. A total drilling length of approximately $76 \mathrm{~m}(250 \mathrm{ft})$ was completed for the day.

Installation of the western horizontal well was completed on the fifth day of field work. Approximately $67 \mathrm{~m}$ (220 ft) of drilling were necessary to complete the horizontal portion of the pilot borehole and angle back to ground surface. This was completed in $5 \mathbf{h}$. The exit

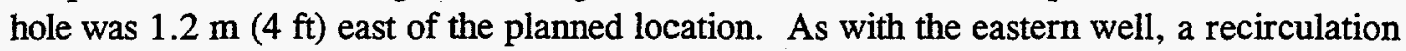
pit was constructed at the exit hole of the western well, the drilling subassembly was removed and replaced with a backreamer, and the well materials housed inside of the shelter casing were attached to the backreamer.

Backreaming and installation of the shelter casing took $4.5 \mathrm{~h}$. During backreaming, water blew out of a borehole that had been drilled previously during characterization of the site geology. A small pit was dug at the blowout location to recover the drilling fluid [approximately $5678 \mathrm{~L}$ (1500 gal)] and pump it back to the mud pit at the drilling rig. After backreaming was completed, the shelter casing was removed in a single piece, and the ends of the well were covered with plastic for protection. The total volume of drilling spoils produced during drilling and installation of the western well was approximately $20 \mathrm{~m}^{3}$ (720 $\left.\mathrm{ft}^{3}\right)$.

On the sixth day of field work, Mears personnel demobilized the drilling equipment from the site. This task was completed in $5 \mathrm{~h}$. FlowTex and ORNL personnel marked the path of the horizontal wells on the ground surface. The backhoe operator from PORTS filled in the remaining mud pits and graded the disturbed areas at both well locations. 
Table 3.1 summarizes the production rates and total time requirements for drilling and installation of the horizontal wells.

\subsection{Surface Completions}

At the surface, a recessed manhole was installed at each end of each well such that the blank casings from the horizontal wells terminate in the manholes (a total of four manholes; Fig. 3.1). A backhoe operator from PORTS installed two horizontal sections of $10-\mathrm{cm}$ (4-in.)-ID casing between the wells. These two sections of casing terminate inside the manholes and were used to plumb the two wells together.

The manholes provide a clean, dry area for the plumbing and other equipment at the ends of the horizontal wells. The manholes are $1.2 \mathrm{~m}(4 \mathrm{ft})$ deep and are constructed of $1.5-\mathrm{m}(5-\mathrm{ft})-$ diameter steel culvert pipe. The floor of the manholes is lined with gravel. A sump bucket was installed in the floor of each manhole so that a submersible pump can be used to remove excess water. Insulated weather-tight lids were installed over the manholes to prevent infiltration by rainwater and surface-water runoff. Four bumper posts were installed around each manhole to protect against vehicle traffic.

The surface locations of the horizontal wells were surveyed with a horizontal accuracy of \pm $15 \mathrm{~cm}( \pm 0.5 \mathrm{ft})$ and a vertical accuracy of $\pm 0.3 \mathrm{~cm}( \pm 0.01 \mathrm{ft})$. To ensure the required accuracy, the survey was looped and closed. Each well is identified by stamped numbers on the side of the protective casing. The horizontal wells are numbered CTS-HW-1 (the east well in Fig. 3.1) and CTS-HW-2 (the west well in Fig. 3.1), in the order of their installation. Figure 3.2 shows surveyed cross sections of the wells based on navigation data collected during drilling.

\subsection{Initial Well Development}

FlowTex recommended that the drilling mud be allowed to break down for at least 10 days before beginning well development. FlowTex also recommended that the horizontal wells be developed by placing a pump at each end of the porous filter and pumping until the extracted water became as clear as practical.

The horizontal wells were developed by ORNL/ETS during early November 1994, following a 10-day waiting period. One generator was used for well development, so it was possible to pump from only one end of each well rather than from both ends. Each end of each well was developed with an initial pumping rate of $15 \mathrm{~L} / \mathrm{min}(4.0 \mathrm{gal} / \mathrm{min})$. The pumping rate was increased as time progressed and near the end of development averaged 45 to $57 \mathrm{~L} / \mathrm{min}(12.0$ to $15.0 \mathrm{gal} / \mathrm{min}$ ). Development water from each well end was initially cloudy, but cleared up after about $1 \mathrm{~h}$ of pumping. Pumping rates, turbidity, $\mathrm{pH}$, temperature, and specific conductance were monitored and recorded during the development process. The water generated during development was routed to a nearby drainage swale. 
Table 3.1 Task summary for drilling and installation of the horizontal wells

\begin{tabular}{|c|c|c|}
\hline Activity & Production rate & Total time \\
\hline $\begin{array}{l}\text { Casing and filter assem- } \\
\text { bly }\end{array}$ & $0.5 \mathrm{~h} /$ weld & $\begin{array}{l}4 \mathrm{~h} \text { to construct four sections } \\
\text { of blank casing (two welds/ } \\
\text { section). Each section was } \\
120 \mathrm{ft} \text { long. } \\
19 \mathrm{~h} \text { to construct two porous } \\
\text { well filters ( } 19 \text { welds/filter). } \\
\text { Each filter was } 230 \mathrm{ft} \text { long. } \\
4 \mathrm{~h} \text { to construct the shelter cas- } \\
\text { ing ( } 11 \text { welds/casing). The } \\
\text { shelter casing was } 480 \mathrm{ft} \text { long. }\end{array}$ \\
\hline Drilling (eastern well) & $39 \mathrm{ft} / \mathrm{h}$ (average rate) & $12 \mathrm{~h}$ to drill $470 \mathrm{ft}$ \\
\hline $\begin{array}{l}\text { Backreaming with } \\
\text { simultaneous well in- } \\
\text { stallation (eastern well) }\end{array}$ & $85.5 \mathrm{ft} / \mathrm{h}$ (average rate) & $5.5 \mathrm{~h}$ to backream $470 \mathrm{ft}$ \\
\hline Shelter casing removal & $96 \mathrm{ft} / \mathrm{min}$ & $\begin{array}{l}5 \text { min to extract } 480 \mathrm{ft} \text { shelter } \\
\text { casing (same for eastern and } \\
\text { western wells) }\end{array}$ \\
\hline Drilling (western well) & $36 \mathrm{ft} / \mathrm{h}$ (average rate) & $13 \mathrm{~h}$ to drill $470 \mathrm{ft}$ \\
\hline $\begin{array}{l}\text { Backreaming with } \\
\text { simultaneous well in- } \\
\text { stallation (western well) }\end{array}$ & $104 \mathrm{ft} / \mathrm{h}$ (average rate) & $4.5 \mathrm{~h}$ to backream $470 \mathrm{ft}$ \\
\hline
\end{tabular}


During development, approximately $10,100 \mathrm{~L}(2,670$ gal) were removed from the north end of the west well, $69,300 \mathrm{~L}(18,320 \mathrm{gal})$ from the south end of the west well, $8100 \mathrm{~L}(2,140$ gal) from the north end of the east well, and $18,000 \mathrm{~L}(4,770 \mathrm{gal})$ from the south end of the east well. A very large volume of water was extracted from the south end of the west well to verify that the water quality of the development water had stabilized. As shown in Table 3.2 , there was very little difference in water quality characteristics in development water from the west and east wells, so it can be concluded that the smaller volume of water extracted from the east well was sufficient for stabilization of the water quality parameters.

As discussed in Sect. 8 of this report, extended operation of the horizontal well recirculation system revealed that this method of well development (pumping until the water became clear) was inadequate. The horizontal wells were later developed successfully by water jetting and overpumping (Sect. 8).

Table 3.2 Water quality of development water from the horizontal wells

\begin{tabular}{|l|c|c|}
\cline { 2 - 3 } \multicolumn{1}{c|}{} & West Well & East Well \\
\hline Temperature, ${ }^{\circ} \mathrm{C}$ & 13.8 & 13.9 \\
\hline $\begin{array}{l}\text { Specific Conductance, } \\
\mathbf{m V} / \mathbf{c m}\end{array}$ & 930 & 1520 \\
\hline pH & 5.7 & 5.0 \\
\hline Turbidity, NTU & 2.7 & 2.3 \\
\hline
\end{tabular}




\section{Piezometer Installation and Development}

ORNL/ETS directed the installation of 22 piezometers at the CTS during November and December 1994. Figure 3.1 shows the piezometer locations. The piezometers were constructed of 5-cm (2-in.)-ID polyvinyl chloride (PVC) with variable screen lengths [typically 0.9 to $1.2 \mathrm{~m} \mathrm{(3} \mathrm{to} 4 \mathrm{ft})$ ]. Nineteen of the piezometers were installed in the Gallia with depths ranging from 7.9 to $9.1 \mathrm{~m}$ ( 26 to $30 \mathrm{ft}$ ) bgs (Table 4.1$)$. Three of the piezometers

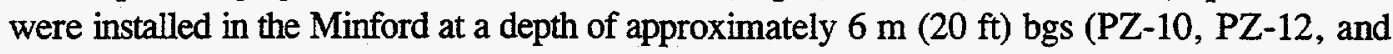

Table 4.1. Piezometer survey data and screened intervals

\begin{tabular}{|c|c|c|c|c|c|c|}
\hline $\begin{array}{l}\text { Piezom- } \\
\text { eter } \\
\text { number }\end{array}$ & $\begin{array}{l}\text { Top of } \\
\text { casing } \\
\text { ft amsi }\end{array}$ & $\begin{array}{c}\text { Ground } \\
\text { eleva- } \\
\text { tion, } \\
\text { ft amsl } \\
\end{array}$ & $\begin{array}{l}\text { Total } \\
\text { depth, } \\
\text { ft bgs }\end{array}$ & $\begin{array}{c}\text { Screen } \\
\text { length, } \\
\text { ft }\end{array}$ & $\begin{array}{c}\text { Screened } \\
\text { interval, } \\
\text { ft bgs }\end{array}$ & $\begin{array}{l}\text { Bedrock } \\
\text { elevation, } \\
\text { ft amsl }\end{array}$ \\
\hline PZ-01 & 661.83 & 660.35 & 28.5 & 3.0 & 22.8 to 25.8 & 635.35 \\
\hline PZ-02 & 661.82 & 660.21 & 27.0 & 4.0 & 22.0 to 26.0 & 634.21 \\
\hline $\mathrm{PZ}-03$ & 661.16 & 659.62 & 25.5 & 3.0 & 21.7 to 24.7 & 634.62 \\
\hline PZ-04 & 662.51 & 660.93 & 25.7 & 2.5 & 23.2 to 25.7 & $\ldots$ \\
\hline$P Z-05$ & 664.64 & 663.10 & 29.0 & 4.0 & 25.0 to 29.0 & 636.14 \\
\hline PZ-06 & 663.89 & 662.26 & 29.0 & 3.5 & 24.5 to 28.0 & 635.89 \\
\hline PZ-07 & 658.60 & 657.09 & 29.0 & 4.0 & 19.5 to 23.5 & 634.60 \\
\hline $\mathrm{PZ}-08$ & 659.19 & 657.73 & 29.0 & 4.5 & 20.0 to 24.5 & 634.94 \\
\hline PZ-09 & 661.93 & 660.44 & 27.5 & 4.0 & 23.5 to 27.5 & 633.19 \\
\hline $\mathrm{PZ}-10$ & 662.08 & 660.44 & 20.0 & 7.0 & 12.0 to 19.0 & - \\
\hline $\mathrm{PZ}-11^{\prime}$ & 663.82 & 662.25 & 29.5 & 4.0 & 24.5 to 28.5 & 635.32 \\
\hline $\mathrm{PZ}-12$ & 663.59 & 662.25 & 20.0 & 10.0 & 9.0 to 19.0 & - \\
\hline PZ-13 & 664.65 & 663.08 & 29.5 & 4.0 & 25.5 to 29.5 & 633.83 \\
\hline PZ-14 & 664.81 & 663.08 & 20.0 & 10.0 & 9.0 to 19.0 & - \\
\hline PZ-15 & 662.66 & 661.39 & 29.5 & 3.0 & 24.0 to 27.0 & 634.39 \\
\hline PZ-16 & 663.65 & 662.28 & 29.5 & 4.5 & 24.0 to 28.5 & 633.78 \\
\hline PZ-17 & 663.99 & 662.45 & 29.5 & 4.0 & 25.5 to 29.5 & 632.95 \\
\hline PZ-18 & 662.21 & 660.79 & 29.5 & 4.0 & 23.5 to 27.5 & 633.29 \\
\hline PZ-19 & 664.15 & 662.66 & 29.0 & 5.0 & 24.5 to 29.0 & 634.16 \\
\hline PZ-20 & 664.67 & 663.25 & 29.5 & 4.0 & 25.5 to 29.5 & 633.75 \\
\hline $\mathrm{PZ}-21$ & 663.85 & 662.41 & 29.0 & 4.0 & 25.0 to 29.0 & 633.66 \\
\hline PZ-22 & 663.49 & 662.07 & 29.5 & 3.0 & 24.5 to 27.5 & 634.57 \\
\hline
\end{tabular}

amsl = above mean sea level

bgs $=$ below ground surface 
PZ-14). The piezometers were used to assess the hydraulic influence of the horizontal wells on the surrounding groundwater flow system.

A CME-55 all-terrain drilling rig, utilizing 21-cm (8.25-in.)-OD by 11-cm (4.25-in.)-ID augers, and standard well construction practices were used to install the piezometers. Auger cuttings generated during drilling were handled in accordance with PORTS waste management protocol under the direction of the PORTS CE. Because the CTS is an uncontaminated site, the auger cuttings were spread neatly around the drilling locations.

A detailed geologic log of each borehole was prepared by collecting and logging soil samples with a $1.5-\mathrm{m}$ (5-ft)-long continuous sampler. The sampler was run a few centimeters ahead of the lead auger to obtain undisturbed soil samples. Appendix $C$ provides the geologic logs and piezometer construction diagrams.

The piezometers were constructed with PVC screens and are screened across the entire thickness of the Gallia member, with the well points resting on Sunbury shale in most cases. Screen lengths vary depending on the thickness of the Gallia. In most cases, the screened interval is 0.9 to $1.2 \mathrm{~m} \mathrm{(} 3$ to $4 \mathrm{ft}$ ) long (Table 4.1). PVC riser casing extends from the top of the screened interval to approximately $76 \mathrm{~cm}(30 \mathrm{in}$.) above ground surface. All screen-tocasing and casing-to-casing couplings are flush-threaded. No glues or lubricants were used. The annular space was filled with a 10/20 grade silica sand pack. To minimize influence from the overlying Minford silt, the sand packs were extended a minimum distance above the screened interval. In most cases, the top of the sand pack was $15 \mathrm{~cm}(6 \mathrm{in}$.) above the top of the screened interval. A bentonite seal was placed on top of the sand pack to within 0.9 $\mathrm{m}(3 \mathrm{ft})$ of ground surface using $1-\mathrm{cm}(3 / 8$-in.) bentonite chips. From $0.9 \mathrm{~m}(3 \mathrm{ft}) \mathrm{bgs}$ to the surface, concrete was used to install locking protective casings over the piezometers. Four bumper posts were then installed around each piezometer.

Upon completion, the piezometers were developed by ORNL personnel. Due to the low flow rates encountered, the piezometers were developed with a water jetting tool. Development continued until the water removed from the piezometers was as clear as practical. Development times for each piezometer ranged from 2 to $4 \mathrm{~h}$. Because groundwater at the CTS is uncontaminated, the water that was generated during development was routed to nearby drainage swales.

The locations of the piezometers were surveyed with a horizontal accuracy of $\pm 15 \mathrm{~cm}( \pm$ $0.5 \mathrm{ft})$ and a vertical accuracy of $\pm 0.3 \mathrm{~cm}( \pm 0.01 \mathrm{ft})$. To ensure the required accuracy, the survey was looped and closed. The piezometers are locked and keyed alike with locks supplied by PORTS. Each piezometer is identified by stamped numbers on the side of the protective casing. The piezometers are numbered as: CTS-PZ-01, CTS-PZ-02, etc.

After the network of piezometers was installed and developed, water levels in the piezometers were allowed to stabilize for at least $24 \mathrm{~h}$. Following stabilization, water levels were measured to allow the construction of a baseline potentiometric map shown as Fig. 4.1. Table 4.1 provides land-surface elevations for the control points used to construct the map. Water-level measurements from all of the piezometers completed in the Gallia were measured within as short a time period as possible (approximately $1 \mathrm{~h}$ ) to provide a view of horizontal flow directions and gradients at the CTS. Baseline water levels in the three piezometers completed in the Minford were also measured and recorded during this time period. 


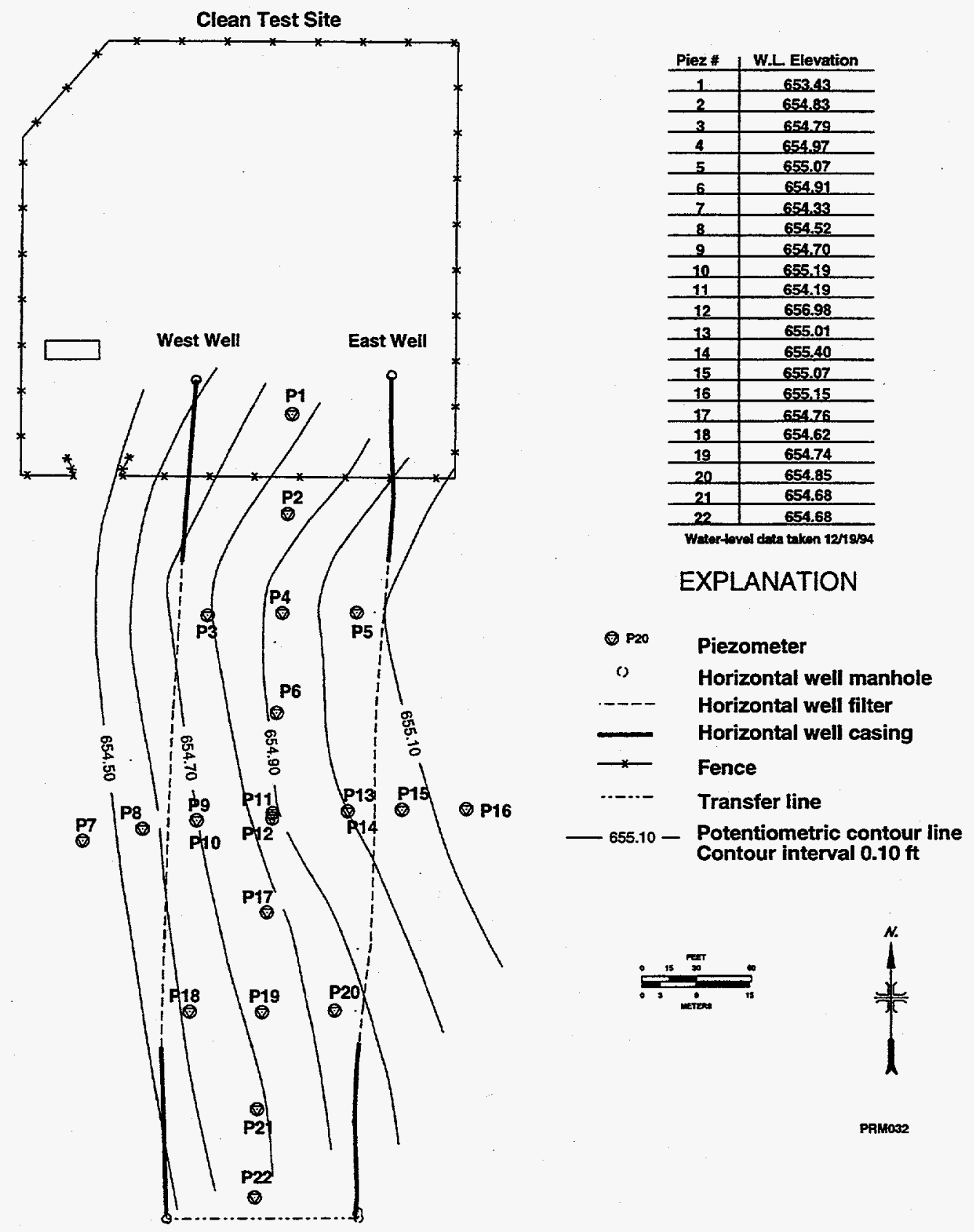

Fig. 4.1. Baseline potentiometric surface map. 


\section{Hydraulic Evaluation of the Horizontal Well Recirculation System}

\subsection{Introduction}

This section discusses tests conducted at the CTS to evaluate aquifer characteristics and the hydraulic performance of the horizontal well recirculation system. The goals of these tests were to determine the efficiency of the horizontal wells and the impact of subsurface heterogeneities. Single-well tests were conducted on 22 piezometers to measure the hydraulic conductivity of the Minford and Gallia members. The results of these tests were compared to estimate the degree and distribution of heterogeneity in the region surrounding the horizontal wells.

Three pumping tests were conducted on the horizontal wells. Each horizontal well was pumped independently to measure yield, area of influence, and hydraulic characteristics of the Gallia. The final test was a dual-well recirculation test that consisted of pumping one horizontal well and injecting into the other.

\subsection{Theoretical Development}

Horizontal wells have been used by the oil industry for years in an attempt to increase production from depleted or low permeability reservoirs (Gilman and Jargon 1992; PEI 1992). Enhanced recovery using horizontal wells has been reported in the literature, with the highest degree of success seen in fractured systems. According to Gilman and Jargon (1992), horizontal wells can be expected to provide both higher rates of recovery and significant incremental recovery in lower permeability formations and essentially accelerated recovery in high permeability reservoirs with marginal increases in ultimate recovery. Expanding horizontal wells to the environmental field for the recovery of groundwater contamination has been discussed by Kaback et al. (1989), and Langseth (1990).

The hydraulic performance of horizontal wells has been evaluated analytically by Ferris (1950), Hantush and Papadopulos (1962), Lohman (1979), Suzuki and Nanba (1990), and Edwards (1991). Horizontal wells have been numerically analyzed by Speake et al. (1992) and Langseth (1990). The impact of formational damage on the efficiency of horizontal wells is discussed by Renard et al. (1990) and Suzuki and Nanba (1990).

To calculate the hydraulic properties of the aquifer at the CTS, several analyses were considered. The most in-depth numerical analysis of horizontal wells is provided by Hantush and Papadopulos (1962). Solutions for flow to a horizontal well are obtained by treating the well as a line sink. If a horizontal well is operated in an infinite confined aquifer of uniform thickness $(b)$, and of uniform transmissivity $(T)$ and storativity $(S)$, the drawdown $\left(s_{i}\right)$ induced by the well lateral is given by the following equations: 


$$
\begin{gathered}
s_{i}=\frac{Q}{4 \pi T}\left(\frac{\alpha}{l} W\left(\frac{\alpha^{2}+\beta^{2}}{4 v t}\right)-\frac{\delta}{l} W\left(\frac{\delta^{2}+\beta^{2}}{4 v t}\right)\right. \\
+\frac{\frac{2}{l}}{\sqrt{4 v t}}\left[L_{0}\left(\frac{\alpha}{\sqrt{4 v t}}, \frac{\beta}{\sqrt{4 v t}}\right)-L_{o}\left(\frac{\delta}{\sqrt{4 v t}}, \frac{\beta}{\sqrt{4 v t}}\right)\right] \exp \left(-\frac{\beta^{2}}{4 v t}\right) \\
\left.+\frac{\frac{2}{l}}{\sqrt{4 v t}} \sum_{1}^{\infty}\left[F\left(\frac{\alpha}{\sqrt{4 v t}}, \frac{\beta}{\sqrt{4 v t}}, \frac{\frac{n \pi}{b}}{\sqrt{4 v t}}\right)-F\left(\frac{\delta}{\sqrt{4 v t}}, \frac{\beta}{\sqrt{4 v t}}, \frac{\frac{n \pi}{b}}{\sqrt{4 v t}}\right)\right] \cos \frac{n \pi z}{b} \cos \frac{n \pi z}{b}\right)
\end{gathered}
$$

$$
\begin{aligned}
\nu & =\frac{T}{S} \\
\alpha & =r \cos \left(\theta-\theta_{i}\right)-r_{c} \\
\beta & =r \sin \left(\theta-\theta_{i}\right) \\
\delta & =r \cos \left(\theta-\theta_{i}\right)-l^{1}
\end{aligned}
$$

$$
\begin{aligned}
L o(u, \pm w) & =\int_{0}^{u} \frac{\beta^{2} e^{-\beta^{2}}}{w^{2}+\beta^{2}} d \beta \\
r & =\sqrt{x^{2}-y^{2}} \\
l^{1} & =r_{c}+l_{1}
\end{aligned}
$$

$F(u, \pm x, y)=-F(-\mu \pm x, y)=\int_{0}^{u} W\left(x^{2}+\beta^{2}, y \sqrt{x^{2}+\beta^{2}}\right.$

where

$$
\begin{array}{ll}
l & =\text { length of well, } \\
K & =\text { hydraulic conductivity } \\
t & =\text { time }
\end{array}
$$


and $W(x, y)$ is the well function for a leaky aquifer. The functions $L_{0}(u, w)$ and $F(u, x, y)$ can be tabulated for a practical range of parameters involved. To our knowledge, however, type curves based on Hantush and Papadopulos (1962) solutions have not been developed. Consequently, their solutions could not be applied when analyzing pumping test data from the CTS. It was necessary to consider other solutions available in the literature.

Lohman (1979) reports a solution developed by Ferris (1950) for determining the decline in head at any distance from a drain (e.g., horizontal well) discharging water at a constant rate from a confined aquifer. The equation is based on the assumption that the aquifer is homogeneous, isotropic, semi-infinite, and the drain completely penetrates the aquifer. For horizontal wells, complete penetration is assumed to imply that the well is located at the base of the aquifer. The equation may be written as

$$
\begin{aligned}
& T=\frac{Q^{*} x}{2 s}\left[\frac{e^{u^{2}}}{u \sqrt{\pi}}-1+\frac{2}{\sqrt{\pi}} \int_{0}^{x / 2 \sqrt{T t / S}} e^{-u^{2}} d u\right] \\
& u=x \sqrt{\frac{S}{4 T t}} \\
& S=\frac{4 T t u^{2}}{x^{2}}
\end{aligned}
$$

where

$$
\begin{aligned}
& x=\text { distance from drain or horizontal well to observation point, } \\
& Q^{*}=\text { pumping rate per unit length of well, } \\
& S=\text { storativity }
\end{aligned}
$$

and where the bracket part of Eq. (5) may be written as $D(u)$, the drain function, to yield

$$
T=\frac{Q^{*} x}{2 s} D(u)_{q}
$$

A type curve for this equation is presented in Lohman (1979). 
Edwards (1991) presents an analytical solution for a horizontal well in an unconfined aquifer based on Darcy's law as

$$
K=\frac{2 Q x}{L\left(h_{2}^{2}-h_{1}^{2}\right)}
$$

where $L$ equals the length of screen and $h$ equals the height of the water at distances $r_{1}$ and $r_{2}$. Adapting this solution for a confined aquifer by assuming $h_{2}{ }^{2}-h_{l}{ }^{2}=\left(h_{2}+h_{l}\right)\left(h_{2}-h_{l}\right)$ and $\left(h_{2}+h_{1}\right)=2 b$, then Eq. (9) becomes

$$
K=\frac{Q x}{b L\left(h_{2}-h_{1}\right)}
$$

In Sect. 5.4, the methods developed by Ferris (1950) and Edwards (1991) are used to evaluate data from the horizontal well pumping tests and to calculate hydraulic properties of the Gallia member at the CTS.

\subsection{Piezometer Hydraulic Tests}

Bail and slug tests were conducted on 22 piezometers to measure the hydraulic conductivity of the Gallia and overlying Minford member. Variations in hydraulic conductivity were used to evaluate the heterogeneity of the system. Muck et al. (1996) presents test results from the individual piezometers. These test results are summarized below.

Hydraulic conductivity values for the Minford range from $2 \times 10^{-5}$ to $4 \times 10^{-5} \mathrm{~cm} / \mathrm{s}(0.05$ to $0.10 \mathrm{ft} / \mathrm{d}$ ). These values are within the expected range for a silty-clay formation. The Gallia shows a large range in permeability values of $7 \times 10^{-6}$ to $6 \times 10^{-3} \mathrm{~cm} / \mathrm{s}(0.02$ to 18 $\mathrm{ft} / \mathrm{d}$ ). These values are typical for a silty clay to sandy formation. Large variations in hydraulic conductivity indicate that the Gallia exhibits a large degree of heterogeneity. Heterogeneity based on the hydraulic tests is supported by results of the geologic investigation that showed large variations in Gallia thickness and lithology across the site.

Figure 5.1 shows hydraulic conductivity values for the individual piezometers. The presence of zones or channels of higher permeability can be inferred from these results. Two higher permeability zones trend from PZ-05 to PZ-09 and from PZ-20 to PZ-09. Whether these individual channels are part of a historical meander in the Gallia member is only speculative based on the limited amount of information; however, it is clear that there are permeable zones or channels in the Gallia capable of transporting most of the groundwater in the vicinity of the CTS. 


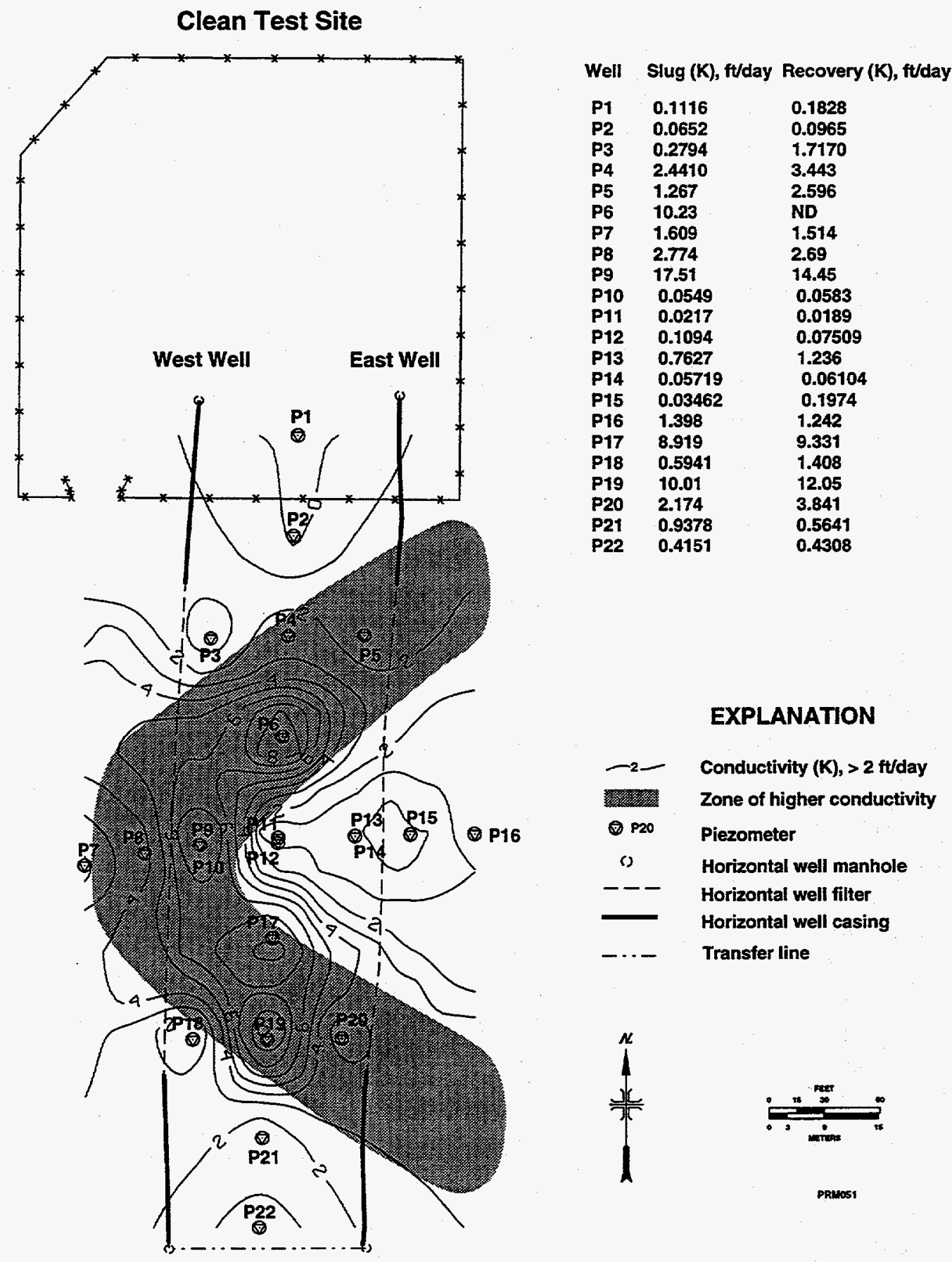

Fig. 5.1. Hydraulic conductivity values based on single-well tests and the distribution of $K$ at the CTS. 


\subsection{Horizontal Well Pumping Tests}

Each horizontal well pumping test was conducted by placing a 3-in. submersible pump at the base of the well next to the filter. A flow totalizer was connected to the discharge line to monitor pumping rates. Water from the single horizontal well tests was routed by fire hoses to a drainage ditch. Pumping rates were allowed to vary less than $2 \%$ during the individual pumping tests. For the recirculation tests, two pumping rates were tested, and each flow rate was held at a consistent level.

Water-levels were monitored using pressure transducers and water-level indicators. Seven piezometers were equipped with pressure transducers for continuous water-level measurements. Water levels in 22 piezometers were periodically measured by hand with a waterlevel indicator and were recorded in the field logbook. In addition, water levels in each end of the horizontal wells were periodically monitored during the tests. Data from the pressure transducers are presented in Appendices D, E, and F.

Pretests were conducted to determine the optimal pumping rate. The eastern horizontal well produced approximately $57 \mathrm{~L} / \mathrm{min}(15 \mathrm{gal} / \mathrm{min})$ for $4 \mathrm{~h}$ before going dry. A rate of $45 \mathrm{~L} / \mathrm{min}$ (12 gal $/ \mathrm{min}$ ) was selected for both individual horizontal wells tests. The pumping rate was increased to 57 and $76 \mathrm{~L} / \mathrm{min}$ (15 and $20 \mathrm{gal} / \mathrm{min}$ ) for the dual-well horizontal recirculation tests.

A minimum pumping test of $24 \mathrm{~h}$ was conducted on each horizontal well. Conventional curve-matching analyses were performed in the field to ensure that the duration of the tests were sufficient to assess aquifer boundary conditions. The recirculation test was conducted for a longer period of time to assess different pumping rates and well efficiency. Based on the results of the pumping tests, it was possible to determine the yield of the individual horizontal wells, the recirculation rate, the extent of drawdown, and the influence of heterogeneities in the Gallia on the horizontal well recirculation system.

\subsubsection{West Well Pumping Test}

\subsubsection{Well Yield}

The west horizontal well was pumped at a rate of $45 \mathrm{~L} / \mathrm{min}(12 \mathrm{gal} / \mathrm{min})$ for $25 \mathrm{~h}$. At the end of the test, there were approximately $1.9 \mathrm{~m}(6.2 \mathrm{ft})$ of available drawdown in the horizontal well. To operate the well for an extended period of time, the pumping rate would need to be decreased to approximately $38 \mathrm{~L} / \mathrm{min}(10 \mathrm{gal} / \mathrm{min})$.

\subsubsection{Aquifer Response to Pumping}

The area of influence for horizontal wells refers to the aquifer region affected by the pumping. For vertical wells, the radius of influence is commonly calculated to illustrate the boundary where groundwater will eventually be extracted by the well. Since horizontal wells are line sinks or sources, a radial term is not appropriate in describing the region of influence. Figure 5.2 is a contour plot of drawdown values in response to pumping the west horizontal 


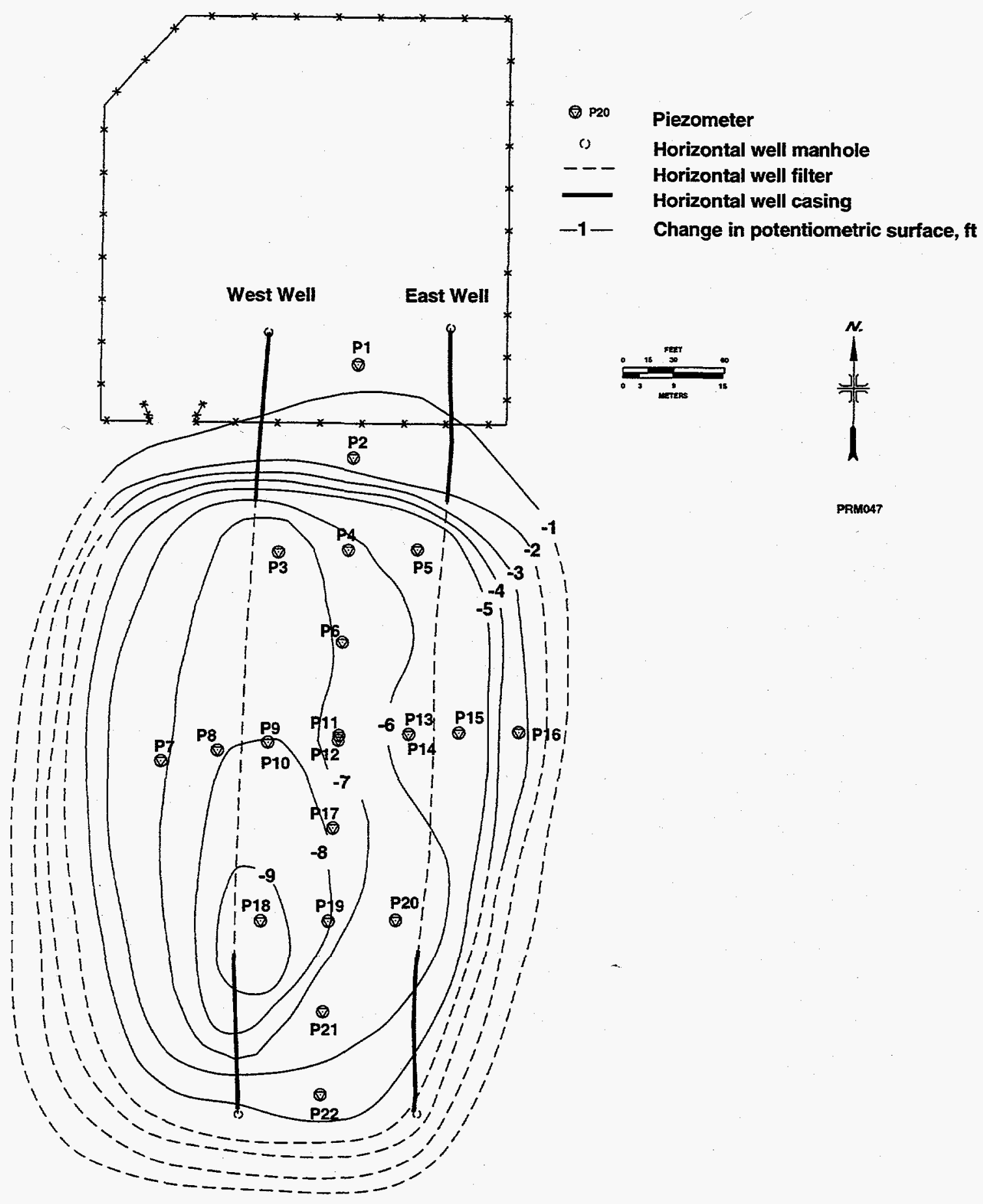

Fig. 5.2. Extent of drawdown in the Gallia resulting from pumping the west horizontal well for $24 \mathrm{~h}$. 
well. As noted earlier, drawdown in the Gallia will be controlled by the geometry of the horizontal wells and the hydrogeologic heterogeneity.

Individual drawdown curves for the west well pumping test are presented in Fig. 5.3. The main difference between the pumping test results for the east and west horizontal wells is the location of the maximum area of drawdown. For the west well pumping test, the southern portion of the well shows the maximum amount of drawdown. These results suggest that the permeability of the Gallia is relatively low in the southern portion of this well. This explanation is supported by the bail test data that indicate a zone of lower permeability in the area of piezometer PZ-18 (Fig. 5.1).

\subsubsection{Hydraulic Characteristics}

Drawdown vs time plots for selected piezometers that were monitored using pressure transducers are presented in Appendix D. Conventional Theis curve analysis was conducted as part of the software plotting program. However, this analysis is based on a vertical well with radial horizontal flow conditions. Using the method for a line sink developed by Ferris (1950), transducer data from PZ-08 collected during the west well pumping test was compared to a type curve presented in Lohman (1979).

Figure 5.4 shows a logarithmic plot of $D(u)$ vs $u^{2}$ for water-level data collected from piezometer PZ-08 during the west well pumping test. As shown, a reasonable match to the type curve was obtained based on a homogeneous, isotropic, semi-infinite area extent system.

Similar results were obtained for curve matching analyses using data for other piezometers. These results indicated that no significant boundaries were encountered during the pumping test. A transmissivity of $1.2 \mathrm{~cm}^{2} / \mathrm{s}\left(110 \mathrm{ft}^{2} / \mathrm{d}\right)$ and storativity value of 0.020 were calculated.

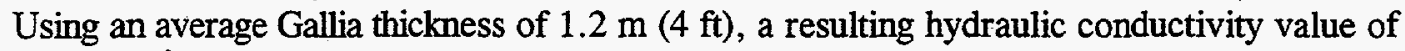
$9.5 \times 10^{-3} \mathrm{~cm} / \mathrm{s}(27 \mathrm{ft} / \mathrm{d})$ can be estimated based on the horizontal well pumping test. This value is substantially higher than that from the single-well tests. However, this is consistent with similar comparisons at other field sites that show pumping test conductivity values as much as an order of magnitude higher than those from single-well pumping tests (Kearl et al. 1988).

The analysis modified from Edwards (1991) yields a hydraulic conductivity value of $1.3 \times 10^{-3} \mathrm{~cm} / \mathrm{s}(3.8 \mathrm{ft} / \mathrm{d})$. This value is significantly lower than predicted by Ferris (1950) and may reflect hydraulic inefficiencies or clogging of the well filter resulting in lower than predicted water levels in the horizontal well. If Eq. (10) is integrated over the limits of $x_{1}$ and $\mathrm{x}_{2}$ to incorporate two piezometers instead on one piezometer and the horizontal well, then the hydraulic conductivity increases to $2.6 \times 10^{-2} \mathrm{~cm} / \mathrm{s}(75 \mathrm{ft} / \mathrm{d})$. 
WEST WELL DRAWDOWNS
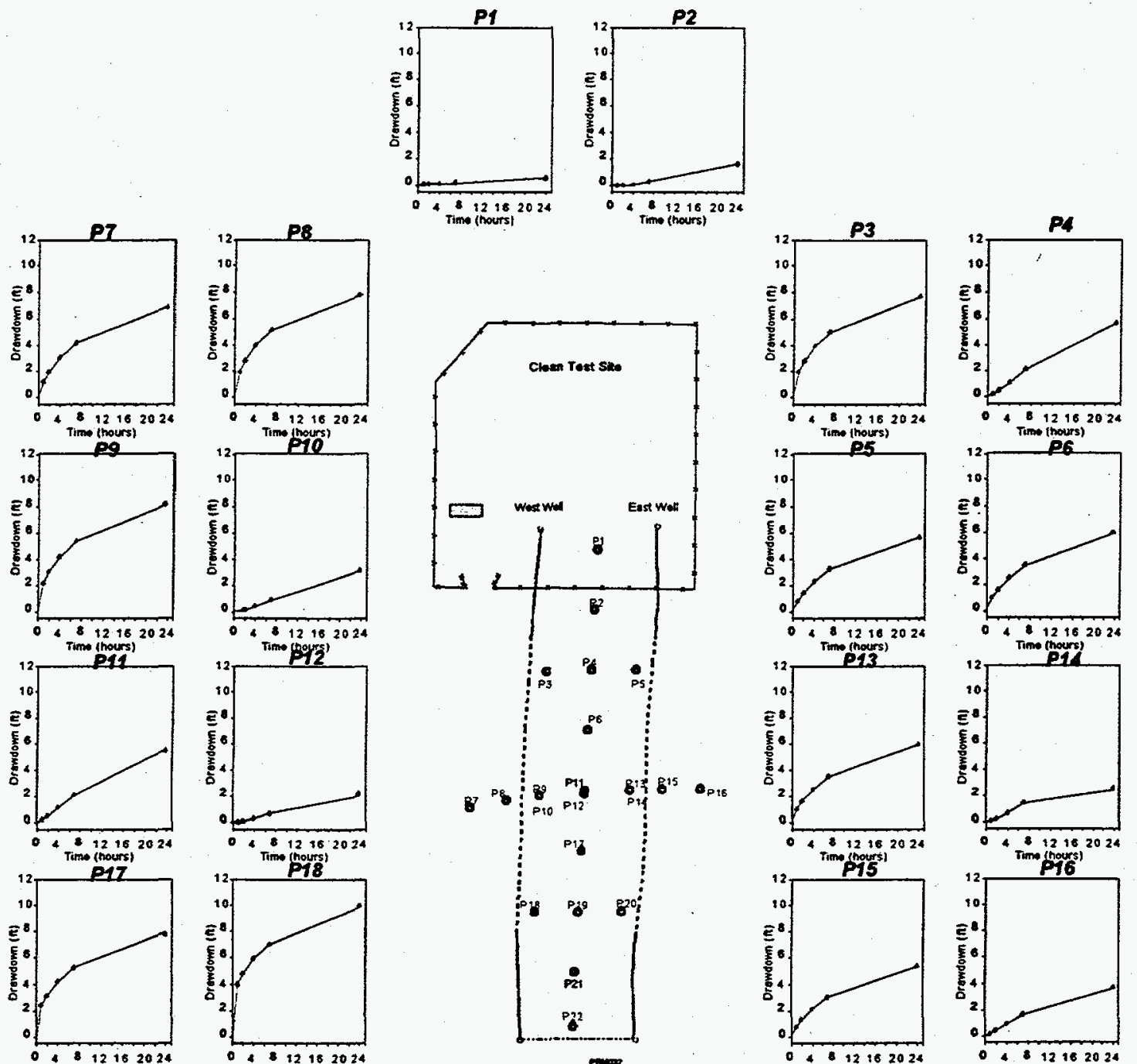

$\sin \log 2$
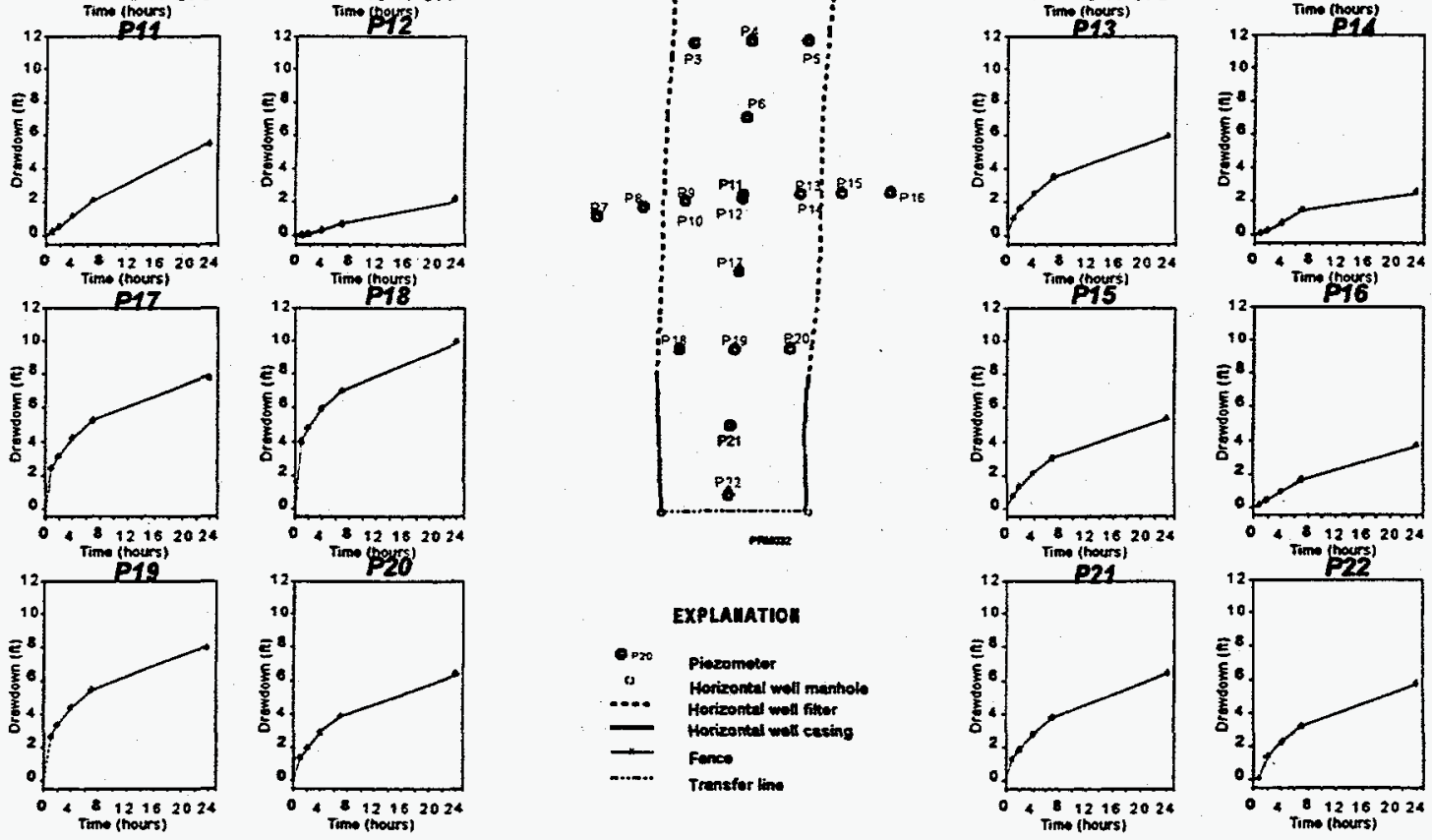

(hours
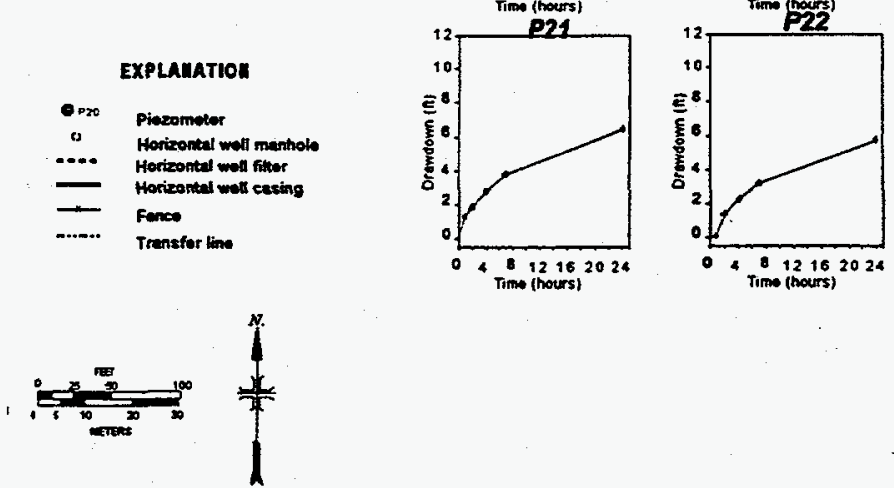

Fig. 5.3. Drawdown graphs for individual piezometers during the west well pumping test. 


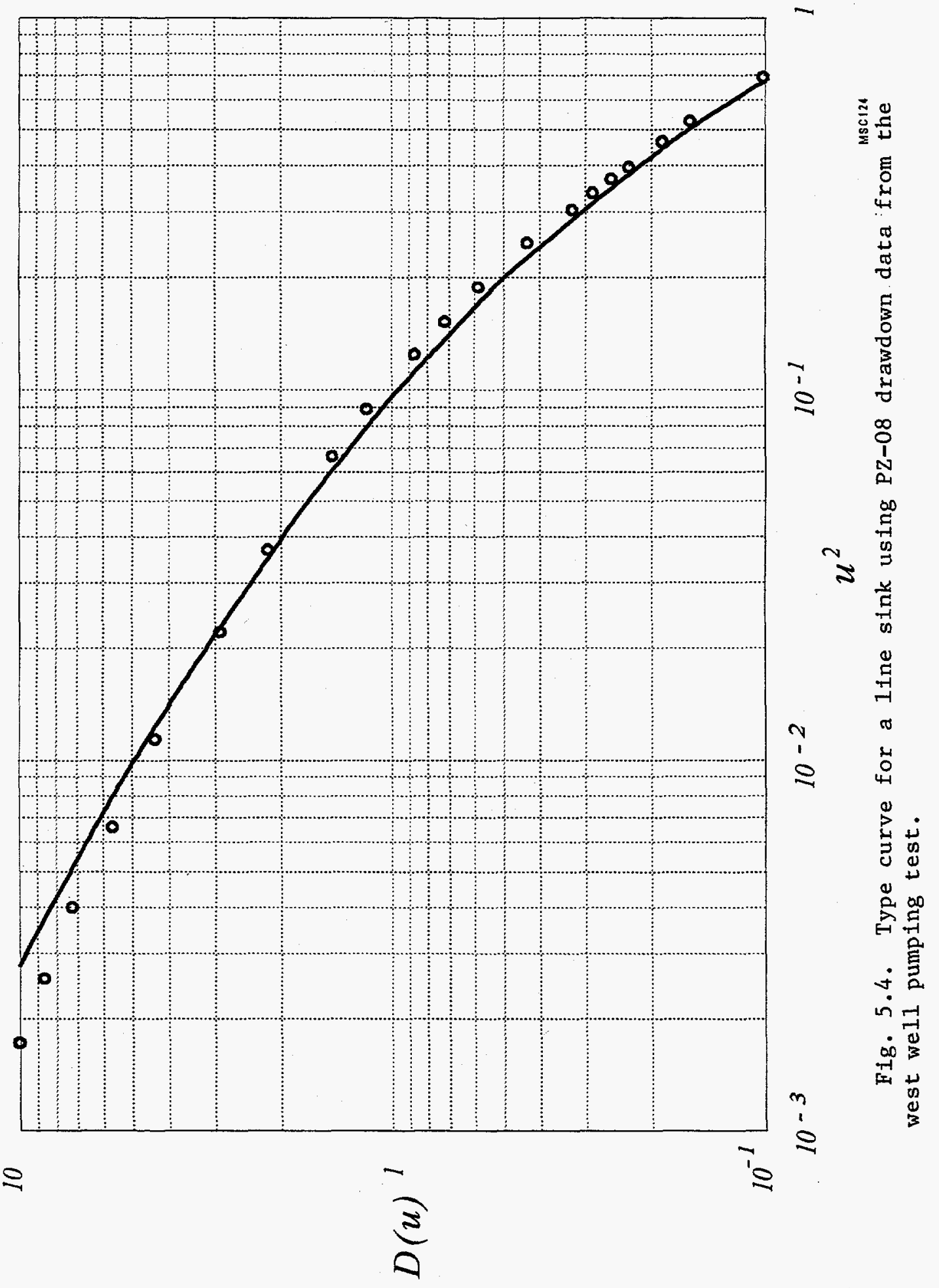


These changes in calculated hydraulic conductivity resulting from whether the horizontal well or a second vertical well is used as an observation point indicate that the horizontal well was inefficient and was clogged during the pumping test. As discussed in Sect. 5.5, the west well filter continued to clog during extended operation, indicating that the initial well development method was inadequate. The west well was later developed successfully using a pressurejetting method (Sect. .8). The higher conductivity calculated by Eq. (10) using two piezometers as compared to Eq. (5) also indicates that $\left(h_{2}+h_{1}\right)=2 b$ is a poor assumption for this system because of the thickness of the confined Gallia combined with the relatively large drawdowns induced by pumping.

\subsubsection{East Well Pumping Test}

\subsubsection{Well Yield}

The east horizontal well was pumped at a rate of $46.6 \mathrm{~L} / \mathrm{min}(12.3 \mathrm{gal} / \mathrm{min})$ for $26 \mathrm{~h}$. At the end of the test, there were only approximately $0.6 \mathrm{~m}(2 \mathrm{ft})$ of available drawdown in the horizontal well. To operate the well for an extended period of time, the pumping rate would need to be decreased to a rate of approximately $38 \mathrm{~L} / \mathrm{min}(10 \mathrm{gal} / \mathrm{min})$.

\subsubsection{Aquifer Response to Pumping}

Results similar to those of the west well pumping test were observed for the east well pumping test. Figure 5.5 illustrates drawdown for the individual piezometers in response to the east well pumping test. Variations in drawdown among the piezometers is a function of location with respect to the horizontal well that is being pumped and variations in permeability. As expected, as the distance from the pumping horizontal well increases, the amount of drawdown decreases. The impact of permeability variations is less clear. Minford piezometers (PZ-10, PZ-12, and PZ-14) show a significant decrease in the amount of drawdown compared to adjacent Gallia piezometers (PZ-09, PZ-11, and PZ-13). This is expected considering the large variations in permeability. It is important to note, however, that water from the Minford is being drawn into the Gallia.

Defining aquifer heterogeneity within the Gallia from the individual piezometer drawdown curves is less clear. Comparing drawdown curves for PZ-09, which shows a high relative permeability based on single-well hydraulic tests, to PZ-11, which yielded a significantly lower permeability, shows similar amounts of drawdown. However, the drawdown in PZ-09 occurs more rapidly than in PZ-11, indicating that the more-permeable sections of the Gallia drain more quickly than the less-permeable regions. Similar results are shown for the area south of the horizontal wells, characterized by PZ-21 and PZ-22, compared with the area north of the horizontal wells, characterized by PZ-01 and PZ-02. Piezometers PZ-21 and PZ-22, which are in a region of high permeability, showed more drawdown at earlier times compared to the less-permeable area surrounding PZ-01 and PZ-02. Distinctions in the rate and magnitude of drawdown as a function of permeability within the Gallia are not as apparent for other piezometers in the CTS. 
EAST WELL DRAWDOWNS
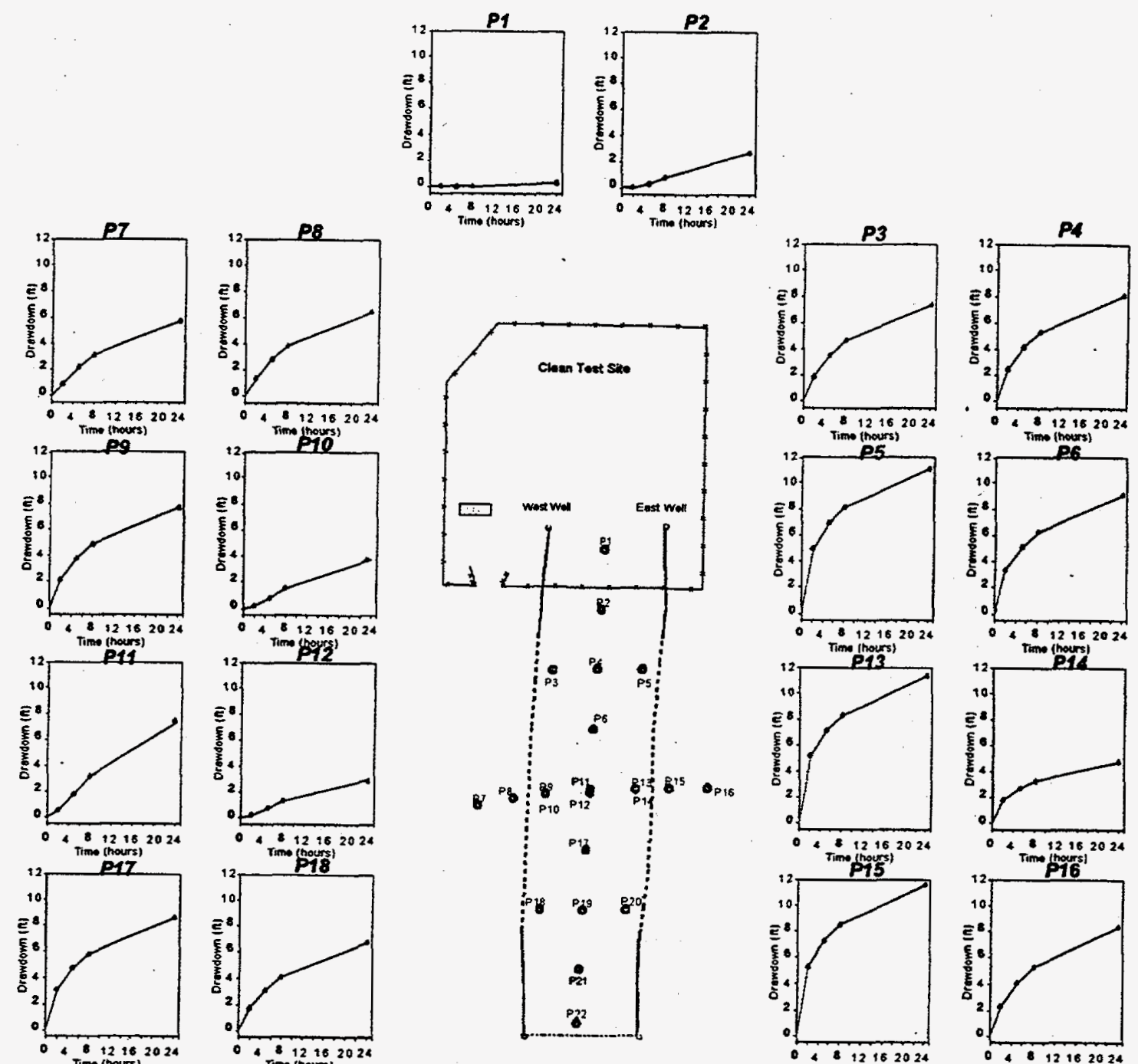

P19
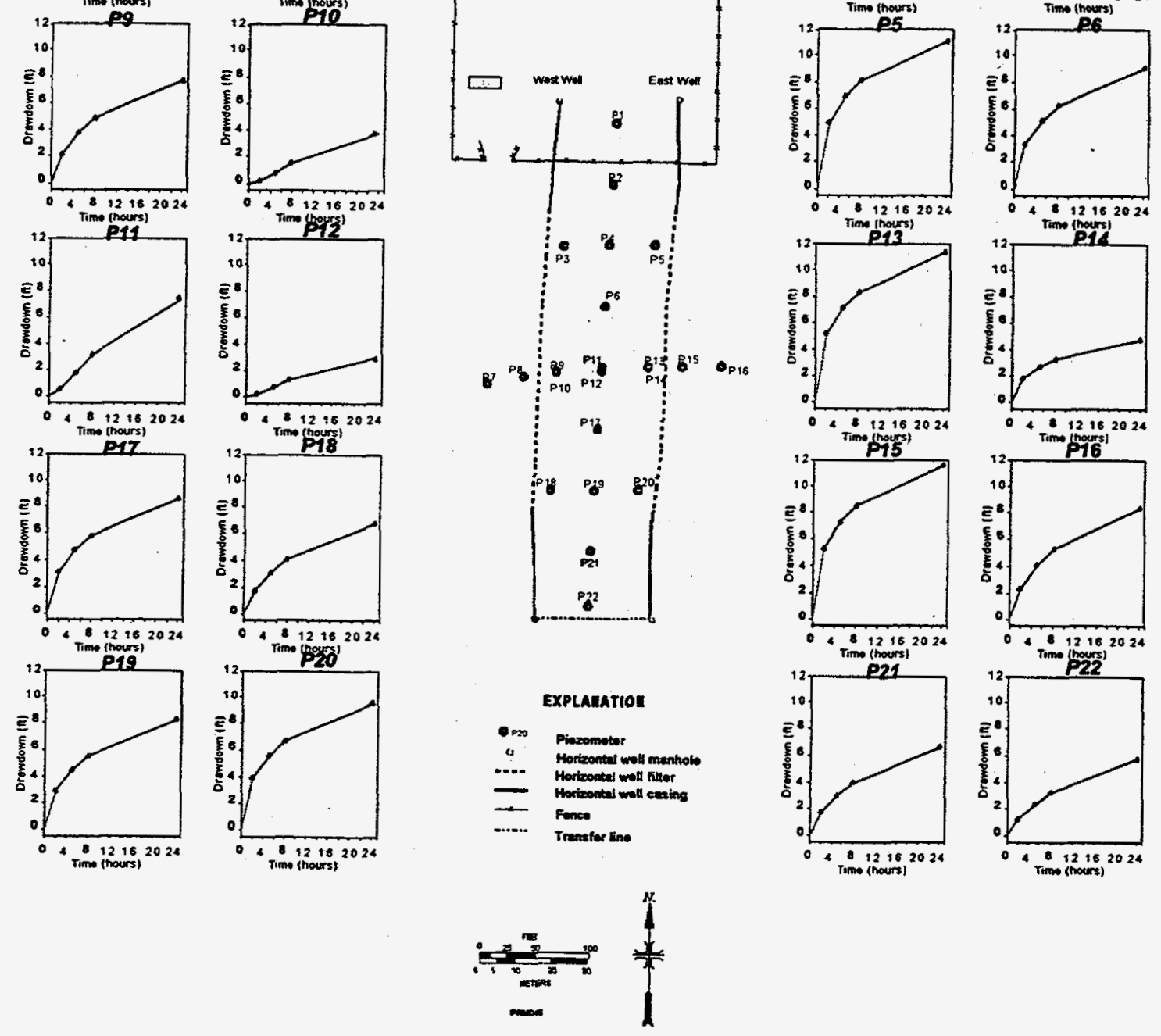

Fig. 5.5. Drawdown graphs for individual piezometers during the east well pumping test. 
The maximum area of drawdown for the east well pumping test is near the center of the horizontal well (Fig. 5.6). This observation would agree with the theoretical predictions for a horizontal well in a homogeneous isotropic aquifer presented by Hantush and Papadopulos (1962). However, there appears to be slightly more drawdown in the northern portion of the horizontal well. Minor permeability contrasts between PZ-05 and PZ-20 do not explain this difference.

A large area of the Gallia is influenced by pumping the east horizontal well. More than 2.2 $\mathrm{m}(7 \mathrm{ft})$ of drawdown is observed at the west horizontal well. It is clear that the recirculation wells could be spaced farther apart and still influence the region between the wells with area of influence.

\subsubsection{Hydraulic Characteristics}

Drawdown vs time curves for the piezometers equipped with transducers are presented in Appendix E. Analysis of the data based on Ferris (1950) yielded similar results to those of the west well pumping test. No significant boundaries were encountered during the test.

\subsubsection{Dual Well Pumping Test}

With the dual well pumping tests, water was extracted from the south end of the west horizontal well. The extracted water was then injected into the south end of the east horizontal well. This mode of operation establishes a horizontal recirculation cell between the two wells.

\subsubsection{Well Yield}

Comparing pumping rates of the individual horizontal wells with the pumping rate during dual-well recirculation shows that it is possible to double the pumping rates under recirculation conditions. The injection well behaves as a constant-head boundary for the extraction well. Consequently, it is possible to pump the extraction well at a higher rate during recirculation than during extraction alone. After $48 \mathrm{~h}$ of pumping, $83 \mathrm{~L} / \mathrm{min}$ (22 $\mathrm{gal} / \mathrm{min}$ ) were pumped and reinjected. The higher pumping rates resulted in higher hydraulic gradients between the horizontal wells.

\subsubsection{Aquifer Response to Pumping}

Individual piezometer drawdown, or displacement, and a contour map of water-level changes during recirculation tests are presented in Fig. 5.7. Areas of maximum drawdown or displacement are enhanced during recirculation. For the east horizontal or injection well, the northern area shows the maximum amount of displacement. For the west horizontal or extraction well, the southern area shows the maximum drawdown. Although not directly supported by the single-well permeability data, the water-level contour map indicates that the 


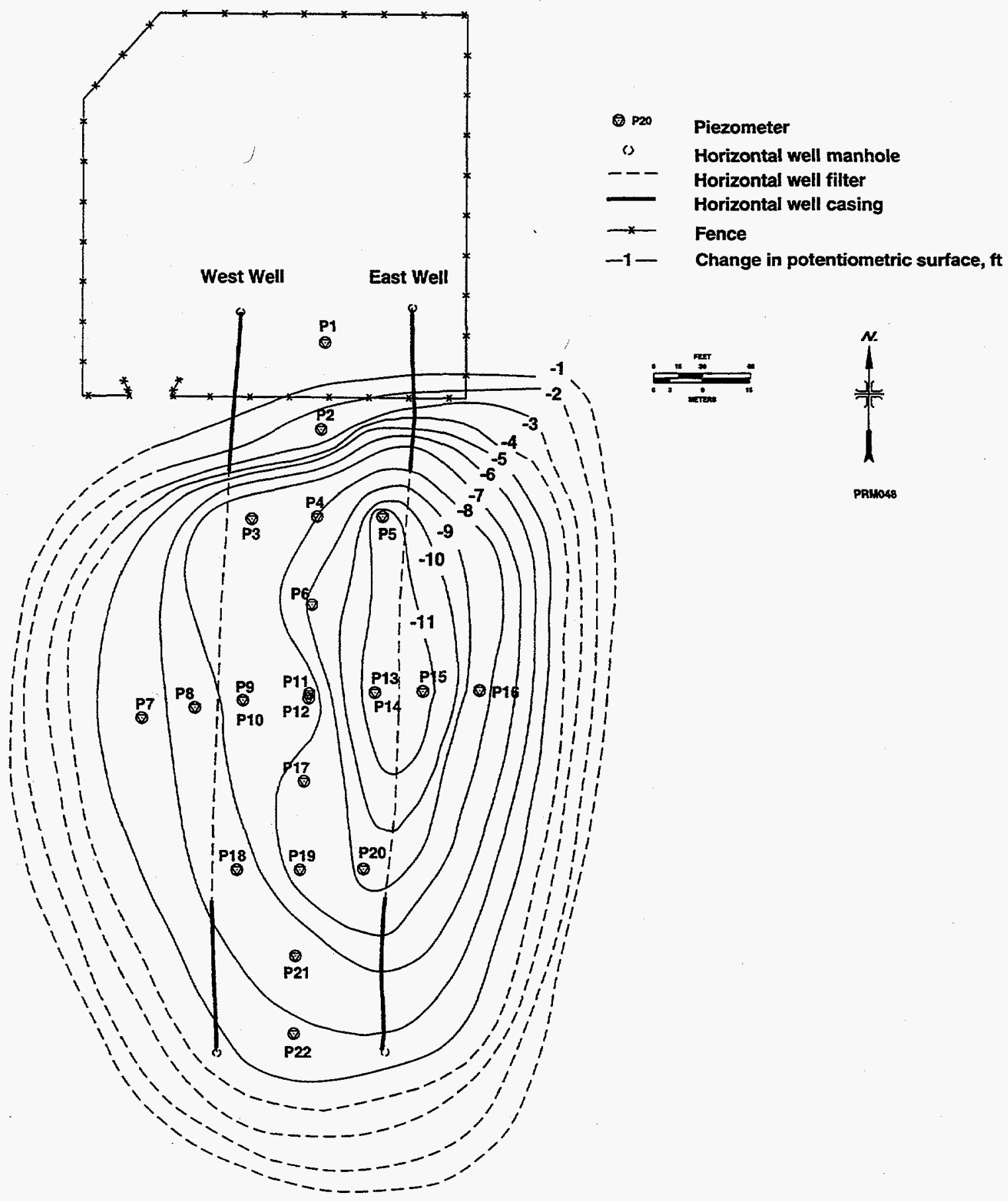

Fig. 5.6. Extent of drawdown in the Gallia resulting from pumping the east horizontal well for $24 \mathrm{~h}$. 
Recirculation Drawdown Contour

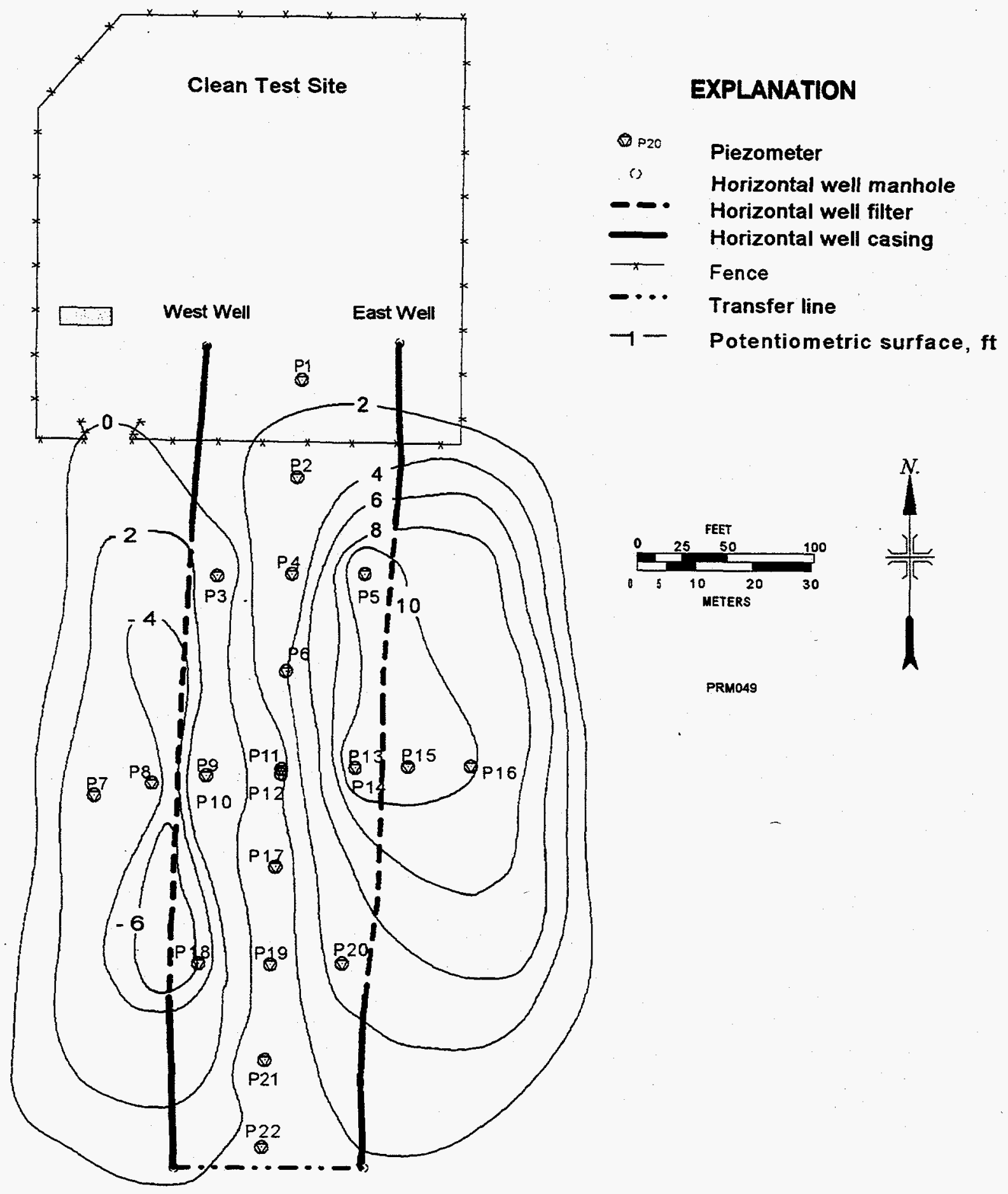

Fig. 5.7. Water-level changes in response to dual well horizontal recirculation. 
maximum hydraulic gradient will occur in a northeast to southwest direction between the recirculation wells. This direction agrees with one of the zones of higher permeability defined by the single-well tests.

\subsubsection{Hydraulic Characteristics}

No hydraulic analysis was conducted on the pumping test data from the recirculation tests. Boundary effects from either the injection or pumping can be qualitatively inferred from the pumping test data presented in Appendix F.

\subsection{Well-Filter Efficiency}

To evaluate the efficiency of the porous well filter, it was necessary to conduct a long-term pumping test. This was accomplished during the tracer test, which is discussed in Sect. 6. The horizontal well recirculation system was initially operated at a rate of $80 \mathrm{~L} / \mathrm{min}(20$ $\mathrm{gal} / \mathrm{min}$ ). However, after $69 \mathrm{~h}$ of pumping, air began entering the horizontal extraction well. Consequently, the pumping rate was reduced to $68 \mathrm{~L} / \mathrm{min}(18 \mathrm{gal} / \mathrm{min})$. Once again, air began entering the horizontal extraction well after two days of pumping at this lower rate. The pumping rate was further reduced to $57 \mathrm{~L} / \mathrm{min}(15 \mathrm{gal} / \mathrm{min})$. A final rate of $30 \mathrm{~L} / \mathrm{min}$ ( $8 \mathrm{gal} / \mathrm{min}$ ) maintained a safe yield in the horizontal extraction well. It was possible to maintain this recirculation rate for 19 days.

The drawdown data from the adjacent piezometers show that quasi-steady-state conditions were established in the Gallia shortly after the initial pumping began. It was after these conditions were established that air began entering the horizontal extraction well. Consequently, deterioration in the efficiency of the porous well filter and not the ability of the Gallia to deliver water to the well was responsible for the decreasing pumping rates.

Porous filter deterioration is believed to be the result of a low-permeability skin developing around the horizontal well filter. Based on the manufacturer's instructions, low-volume pumping was used to develop the horizontal wells. Sediment content in the development water decreased quickly, and the horizontal wells yielded clear water after limited pumping.

This development approach did not remove the fine-grained material from the surrounding formation or fine material introduced during the drilling process. During long-term pumping, this fine-grained material formed a skin of lower permeability surrounding the well filter, which decreased the well efficiency.

Based on the lack of pressure increase observed on the injection side during the recirculation test, a low-permeability skin did not develop around the injection well. Because water was forced out of the porous well filter, fines were not able to clog the formation surrounding the injection well.

As discussed in Sect. 8, it was necessary to redevelop the horizontal wells by modifying conventional well development methods such as water jetting and surging for horizontal well applications. During redevelopment of the wells, the fine-grained material surrounding the 
porous well filter was mobilized, brought into the horizontal well, and removed to develop a permeable skin surrounding the porous filter.

\subsection{Discussion}

Hydraulic testing results for the horizontal well recirculation system indicate a heterogeneous water-bearing zone of moderate permeability. Single-well testing showed hydraulic conductivity values that varied by over two orders of magnitude in the Gallia member. Pumping test results suggested that large-scale features such as permeable channels are not major components of the Gallia member in the CTS. However, the sensitivity of horizontal well pumping tests to detect aquifer boundaries is unclear. The issue of image well theory for horizontal line sinks has not been fully explored at this time.

Piezometers completed in the overlying Minford member yielded several feet of drawdown during the pumping tests. These data indicate that the Minford is contributing water to the Gallia. The amount of water contributed by the Minford does not appear significant compared to the Gallia. Once again, however, this is based on pumping test curves for a line sink.

Water levels in the piezometers were slow to recover to prepumping levels. Piezometers located in the portions of the Gallia that are lower in permeability were extremely slow to recover. Water levels measured $24 \mathrm{~h}$ after completion of the pumping tests consistently showed a recovery of only approximately two thirds of the static levels. Because of the large area impacted by the horizontal wells, recharge from the surrounding area must travel a large distance to replenish water levels.

Recirculation tests showed that it was possible to increase the average hydraulic gradient to 0.15 between the wells. The hydraulic gradient remained fairly consistent between the horizontal wells, with some variations due to heterogeneity. Under these conditions, water will travel approximately two orders of magnitude faster than under ambient conditions, with only permeability controlling groundwater flow velocities between the horizontal wells.

Further research and hydraulic analyses using numerical models would be necessary to complete a comprehensive description of the Gallia and Minford hydrodynamics. Such analyses were beyond the scope of this project. 


\section{Tracer Test}

\subsection{Introduction}

This section discusses the results of a bromide tracer test conducted on the horizontal well recirculation system. Results of hydraulic tests and colloidal borescope measurements are compared with the tracer data to provide additional data to assess the heterogeneity of the Gallia. Piezometers in the overlying Minford were also sampled to determine the impact of circulating fluids on these fine-grained sediments.

The purpose of the tracer test was to measure travel time and distribution and concentration of tracers in the vicinity of the horizontal recirculation wells. Understanding travel time is important in determining the number of pore volumes per unit time that can be recirculated by the well system. The distribution and concentration of tracers based on piezometer sampling data provide an understanding of the impact of heterogeneity on recirculation efficiency. It is widely recognized that subsurface heterogeneity is a controlling influence on the distribution of contaminants and the hydrodynamic pathways that provide access to the contaminants.

Three tracers were selected for the test: 1) an ionic tracer, bromide (as potassium bromide); 2) a fluorescent dye, fluorescein; and 3) a colloidal tracer, SNOMAX, an ice-nucleating active-bacteria product. This report focuses on the results of the bromide tracer test. Muck et al. (1996) discusses the fluorescein and SNOMAX tracer test results.

\subsection{Description of the Bromide Tracer}

Bromide and chloride are the most commonly used ionic tracers. This type of tracer is introduced to the subsurface as a salt (e.g., potassium bromide) where it ionizes in water, resulting in separate charged species (anions and cations). In most cases, anions (e.g., $\mathrm{Br}^{-}$) are not affected by the aquifer medium and serve as excellent conservative tracers (i.e., they travel with the same velocity and direction as the water). Bromide was chosen as a tracer due to its low background concentration in soils, high solubility, and low toxicity. Analysis for ionic tracers can be conducted in the field using test kits or ion-selective electrodes. More accurate analysis is possible in the laboratory using ion chromatography. However, laboratory analyses are expensive and require a longer turn-around time.

\subsection{Stock Tracer Concentration}

Crystalline potassium bromide $(12.5 \mathrm{~kg}$ ) was mixed in a $1,890-\mathrm{L}$ (500-gal) tank containing groundwater before injection into the east horizontal well (see Sect. 6.5.1). Samples from the tank were collected for analysis prior to injection. The calculated bromide concentration in the stock solution was $4,425 \mathrm{mg} / \mathrm{L}$. The actual bromide concentration (mean value of three samples) was $3,396 \mathrm{mg} / \mathrm{L}$. 
The measured bromide concentration in stock tracer samples was approximately $25 \%$ less than the calculated concentration. This difference is attributed to incomplete solubilization of the $\mathrm{KBr}$ crystals. The ambient temperature at the time of injection was approximately $25^{\circ} \mathrm{F}\left(-4^{\circ} \mathrm{C}\right)$. The tank solution was mixed for less than one hour due to concerns that the solution would freeze after addition of the SNOMAX. This relatively short mixing time, combined with a cold water temperature, resulted in reduced dissolution of the $\mathrm{KBr}$ crystals.

\subsection{Bromide Analysis}

Analysis for bromide was performed in the on-site field laboratory at PORTS using an ionspecific electrode. This method of analysis was chosen due to its reliability and relative ease of use in the field. Moreover, sample results were quickly available.

Bromide concentrations were determined using an Orion ${ }^{\mathrm{TM}}$ Model $94-35$ bromide electrode and a Model 90-02 double junction reference electrode. Output from the electrodes was measured in millivolts on a Beckman Model $34 \mathrm{pH}$ meter. To reduce potential interference, an ionic strength adjustor of $5 \mathrm{M} \mathrm{NaNO}_{3}$ was added at the rate of $2 \%$ by volume to all samples and standards. A daily calibration curve was produced by measuring a series of bromide standards $(0.0,0.8,1.6,3.2,8.0,80$, and $800 \mathrm{mg} / \mathrm{L})$. Millivolt readings for each standard were entered into a linear regression program, and a standard curve was determined. The standard curve was then used to convert sample millivolt readings to bromide concentrations. All calibration and sample data were recorded on logsheets and in the project laboratory notebook.

No significant problems were encountered during bromide analyses. Although some variability was observed in the standard curve calculation on a day-to-day basis, this variability is typical for electrochemical analyses. Routine maintenance during the project included replacing the filling solutions on the reference electrode and cleaning the bromide electrode with polishing strips.

\subsection{Field Methods}

\subsubsection{Injection of Tracer}

A $1,890-\mathrm{L}$ (500-gal) tank was used to mix the tracer solution prior to injection. A series of valves connected the mixing tank to the piping between the horizontal wells. Prior to injecting the tracer solution, the recirculation system was operated for $26 \mathrm{~h}$ to establish quasisteady-state groundwater flow conditions. Water was routed from the extraction well to the mixing tank approximately $2 \mathrm{~h}$ prior to injection. Tracers were added to the tank and mixed with a submersible pump located at the base of the tank. Immediately prior to and during the injection, the tracer concentrations were repeatedly measured in the mixing tank.

During the injection of the tracer solution, water from the extraction well was routed to a nearby ditch. The tracer solution in the mixing tank was pumped at the same rate into the horizontal injection well as the pump rate from the horizontal extraction well. After the 
tracer solution was injected, water from the extraction well was immediately rerouted to the injection well. Sampling of piezometers adjacent to the injection well began immediately.

The injection procedure resulted in a net deficit of $1,890 \mathrm{~L}$ ( $500 \mathrm{gal}$ ) of water for the first day of the tracer test. Preferably, the mixing tank should have been filled several days prior to the test, and the water-bearing zone allowed to recover. Unfortunately, the SNOMAX tracer is temperature sensitive and with January temperatures well below $0^{\circ} \mathrm{C}$, it was not possible to leave groundwater exposed for several days.

\subsubsection{Well Sampling}

Thirty-three piezometers and the effluent from the extraction well were monitored to assess the rate and extent of tracer migration. The piezometers were completed primarily in the Gallia member with a limited number completed in the overlying Minford member. Nineteen of the piezometers were constructed of 5-cm (2-in.) diameter PVC screened across the entire thickness of the Gallia. Three 5-cm (2-in.) diameter PVC piezometers were completed in the overlying Minford. The remaining 11 piezometers were constructed of $2.5-\mathrm{cm}$ (1-in.) diameter PVC casing and screen and were installed using the U2CRT mobile drilling truck. Figure 6.1 shows the piezometer locations.

Because of differences in piezometer sizes and installation techniques, there is a possibility of sampling variances between the two piezometer types. The 5-cm (2-in.) piezometers were installed with sand packs and were adequately developed. Clear water was obtained from these piezometers throughout the duration of the tests. Conversely, the $2.5-\mathrm{cm}(1-\mathrm{in}$.) piezometers yielded less water with a higher turbidity and may not be as hydraulically connected to the surrounding formation as the $5-\mathrm{cm}$ (2-in.) piezometers. In addition, drilling difficulties during the installation of the 2.5 -cm (1-in.) piezometers resulted in screened intervals that range from the lower Minford to the upper Gallia. This variance is useful for assessing heterogeneity in the Gallia and the impact on the overlying Minford. However, these differences must be considered when comparing sampling data from both types of piezometers. Table 6.1 provides well completion information for the individual piezometers, and the completed well logs are provided in Appendix C.

Water sampling methodology was controlled by the need for an efficient sampling program that rapidly obtained representative samples from the screened portion of the piezometers. It was anticipated that between two to three thousand water samples would be collected as part of the tracer test. Consequently, permanent sampling tubes were installed in each piezometer with the open portion in the middle of the screen. Using the micropurge method discussed by Kearl et al. (1994), piezometers were sampled at a rate of $600 \mathrm{~mL} / \mathrm{min}(0.16 \mathrm{gal} / \mathrm{min})$. Purging consisted of removing $1 \mathrm{~L}(0.3 \mathrm{gal})$ of water then collecting the sample. This purge volume corresponds to approximately two sampling tube volumes. It is believed that this approach yielded water that was representative of the groundwater surrounding the piezometers; sampling required only 3 to $5 \mathrm{~min}$ to complete. The uniformity of the chemistry results discussed in the following sections supports this sampling methodology. 


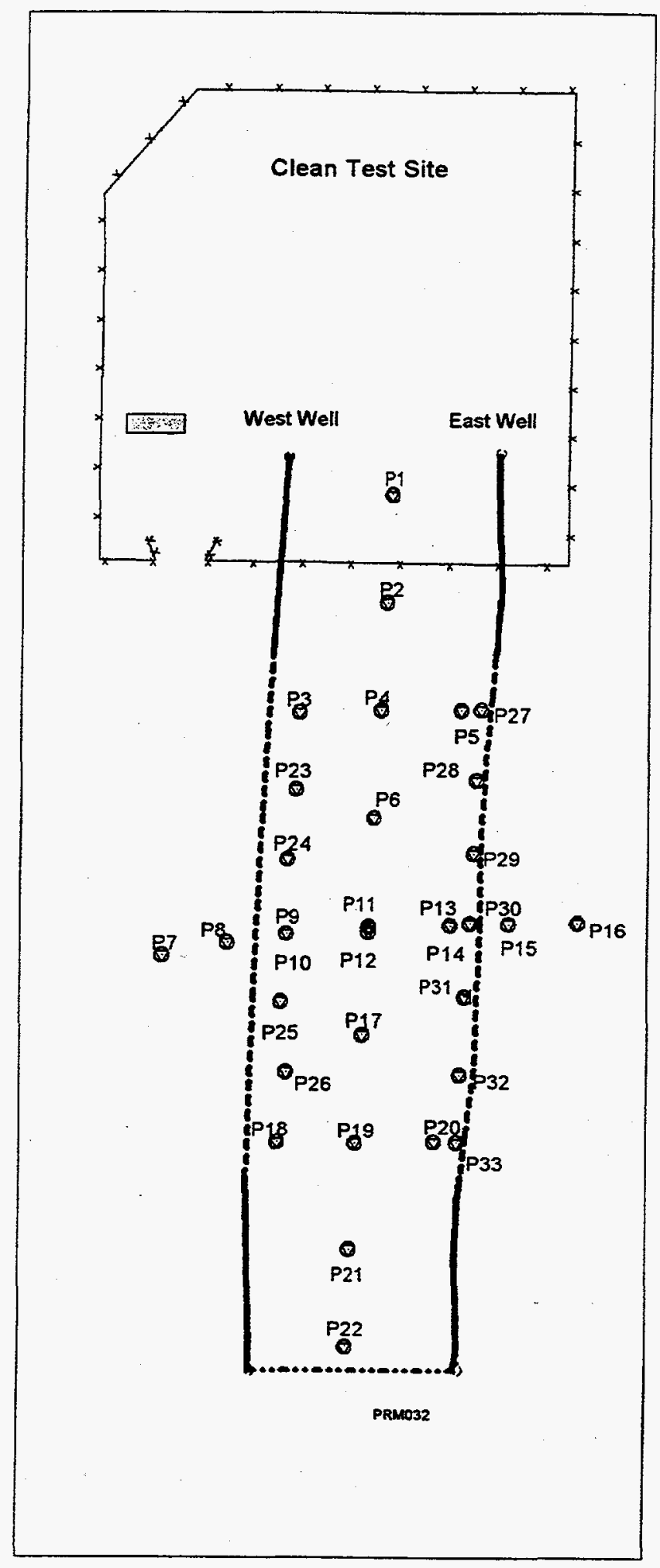

\section{EXPLANATION}

OP20 Piezometer

Horizontal well manhole

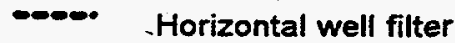

Horizontal well casing

- $x$ Fence

Transfer line

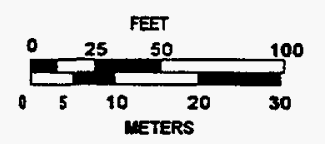

Fig. 6.1. Locations of piezometers sampled during the horizontal recirculation tracer test. 
Table 6.1. Piezometer response to the bromide tracer test

\begin{tabular}{||c|c|c|c|c|c|l||}
\hline Piezometer & $\begin{array}{c}\text { Diameter, } \\
\mathrm{cm}\end{array}$ & Stratigraphic Member & $\begin{array}{c}\text { Average } \\
\text { hydraulic K, } \\
\mathrm{cm} / \mathrm{s}\left(\times 10^{-4}\right)\end{array}$ & $\begin{array}{c}\text { Time to peak } \\
\text { concentration } \\
\text { days }\end{array}$ & $\begin{array}{c}\text { Peak } \\
\text { concentration, } \\
\mathrm{mg} / \mathrm{L}\end{array}$ & Comments \\
\hline PZ-01 & 5 & Gallia & 0.52 & No peak & & Outside main flow field; no tracer detected \\
\hline PZ-02 & 5 & Gallia & 0.28 & No peak & & Outside main flow field; no tracer detected \\
\hline PZ-03 & 5 & Gallia & 3.5 & 14 to 16 & 14 & No clear peak; diffusion controlled \\
\hline PZ-04 & 5 & Gallia & 10 & 3.8 & 46 & Minor spread on breakthrough peak \\
\hline PZ-05 & 5 & Gallia & 9.0 & 0.8 & 95 & Sharp breakthrough peak \\
\hline PZ-06 & 5 & Gallia & 36 & 1.4 & 53 & Sharp breakthrough peak \\
\hline PZ-07 & 5 & Gallia & 5.5 & No peak & 4 & Slight increase in bromide near end of test \\
\hline PZ-08 & 5 & Gallia & 9.7 & No peak & 9 & $\begin{array}{l}\text { Outside main flow field; increased to } \\
\text { background value (diffusion controlled) }\end{array}$ \\
\hline PZ-09 & 5 & Gallia & 56 & 3.1 & 38 & Broad breakthrough peak \\
\hline PZ-10 & 5 & Minford & 0.20 & No peak & & No bromide detected \\
\hline PZ-11 & 5 & Gallia & 0.069 & 2.0 & 46 & Broad breakthrough peak \\
\hline PZ-12 & 5 & Minford & 0.32 & No peak & & No bromide detected \\
\hline PZ-13 & 5 & Gallia & 3.5 & 0.8 & 52 & Sharp breakthrough peak \\
\hline PZ-14 & 5 & Minford & 0.21 & 3.1 & & Broad breakthrough peak \\
\hline PZ-15 & 5 & Gallia & 0.41 & 0.77 & 102 & $\begin{array}{l}\text { Outside main flow field; sharp breakthrough } \\
\text { peak }\end{array}$ \\
\hline
\end{tabular}




\begin{tabular}{|c|c|c|c|c|c|c|}
\hline рәрәјәр әр!шогq оN & & प्रeəd on & IN & proju!̣, & $s^{\prime} z$ & $\overline{82-Z d}$ \\
\hline 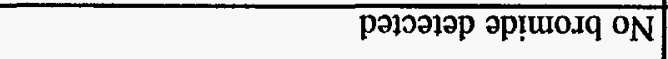 & & Yread $0_{N}$ & LN & p.oju!W & $S^{\prime} z$ & $L Z-Z d$ \\
\hline 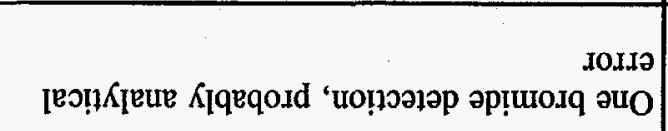 & & yead on & $\mathbf{L N}$ & 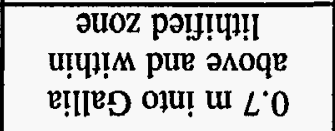 & $s^{\prime} z$ & $9 z-Z d$ \\
\hline 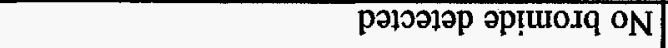 & & Yrad oN & LN & ฉ!!l| & $\mathrm{s}^{\prime} \mathrm{Z}$ & $\mathbf{S Z}-\mathrm{Zd}$ \\
\hline 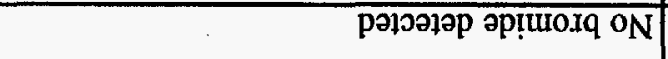 & & प्रe्d on & IN & proju!̣ & $s^{\prime} \tau$ & $t z-Z d$ \\
\hline 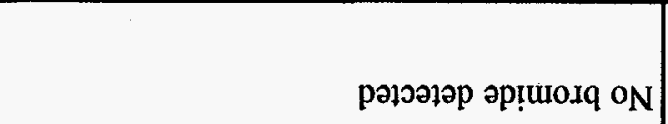 & & yeerd oN & IN & 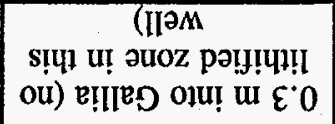 & $s \cdot \tau$ & $\varepsilon z-Z d$ \\
\hline 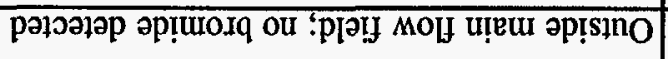 & & प्रerd on & $\bar{S} I$ & Q!IIED & $\mathrm{S}$ & $\overline{z z-Z d}$ \\
\hline 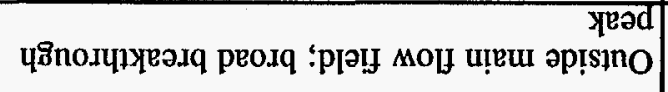 & 62 & $I \cdot S$ & $9 \cdot z$ & B!Iles & $\mathfrak{s}$ & $\mathrm{I} Z-\mathrm{Zd}$ \\
\hline Yएed yônoxulyeəxq dreqs & III & $\mathcal{E} \mathcal{E}^{\prime} 0$ & II & RIIIPD & $\overline{\mathcal{S}}$ & $0 z-Z d$ \\
\hline 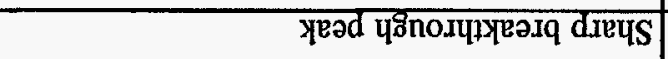 & $L S$ & $\overline{S E} \cdot I$ & $6 \mathcal{E}$ & E!IIED & $\bar{S}$ & $6[-\mathrm{Zd}$ \\
\hline 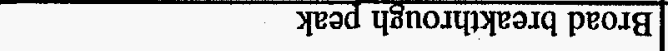 & 92 & $I^{\cdot} \mathcal{E}$ & $\mathcal{S} \mathfrak{\mathcal { E }}$ & E!ILD & $\mathcal{S}$ & $8 \mathrm{I}-\mathrm{Zd}$ \\
\hline 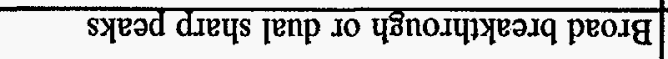 & $\overline{0 \varepsilon}$ & $t \cdot I$ & $\overline{\tau \varepsilon}$ & B!IIPD & $\bar{s}$ & LI-Zd \\
\hline 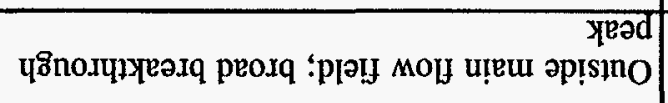 & $6 \varepsilon$ & $8 \cdot t$ & $9 \cdot t$ & B!ILPD & 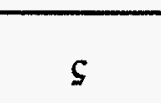 & $9 I-Z d$ \\
\hline stuəururos & $\begin{array}{c}/ 8 \text { ut } \\
\text { 'uo!̣enueวuos } \\
\text { yead }\end{array}$ & 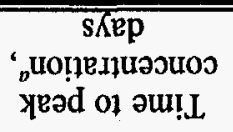 & 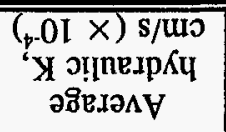 & 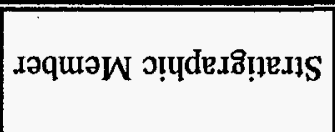 & 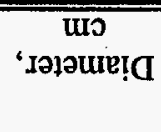 & Iə1aurozə!d \\
\hline
\end{tabular}

(pәnụ̣uos) $\cdot[\cdot 9$ әqq $L$ 
Table 6.1. (continued)

\begin{tabular}{|c|c|c|c|c|c|l||}
\hline Piezometer & $\begin{array}{c}\text { Diameter, } \\
\mathrm{cm}\end{array}$ & Stratigraphic Member & $\begin{array}{c}\text { Average } \\
\text { hydraulic K, } \\
\mathrm{cm} / \mathrm{s}\left(\times 10^{-4}\right)\end{array}$ & $\begin{array}{c}\text { Time to peak } \\
\text { concentration } \\
\text { days }\end{array}$ & $\begin{array}{c}\text { Peak } \\
\text { concentration, } \\
\mathrm{mg} / \mathrm{L}\end{array}$ & \multicolumn{1}{|c|}{ Comments } \\
\hline \hline PZ-29 & 2.5 & Minford & $\mathrm{NT}$ & No peak & & No bromide detected \\
\hline PZ-30 & 2.5 & $\begin{array}{c}0.7 \mathrm{~m} \text { into Gallia } \\
\text { above lithified zone }\end{array}$ & $\mathrm{NT}$ & 0.10 & 119 & Sharp breakthrough peak \\
\hline PZ-31 & 2.5 & $\begin{array}{c}0.8 \mathrm{~m} \text { into Gallia } \\
\text { bbove lithified zone }\end{array}$ & $\mathrm{NT}$ & 2.0 & 45. & Sharp breakthrough peak \\
\hline PZ-32 & 2.5 & Minford & $\mathrm{NT}$ & 0.14 & 36 & Sharp breakthrough peak \\
\hline PZ-33 & 2.5 & Minford & $\mathrm{NT}$ & No peak & & No bromide detected \\
\hline
\end{tabular}

${ }^{a}$ time that the highest bromide concentration occurred $\mathrm{NT}=$ not tested 
An ISCO automated sampler was connected between the horizontal wells to obtain discrete samples of groundwater from the extraction well. Initially, samples were taken every hour, which was later reduced to every $2 \mathrm{~h}$. Results from the horizontal extraction well sampling indicated arrival times for the tracers and the concentrations of tracers being recirculated in the system.

\subsection{Horizontal Well Performance During Tracer Test}

Ideally, a constant pumping rate should have been maintained during the tracer test. Unfortunately, because the well efficiency of the horizontal extraction well continued to deteriorate during the test, the pumping rate was reduced several times as shown in Table 6.2. The variable pumping rate complicated the tracer test and must be considered in interpreting the test results.

Table 6.2. Pumping schedule during the horizontal recirculation tracer test

\begin{tabular}{|c|c|c|c|}
\hline Date & Time & $\begin{array}{c}\text { Total time since tracer } \\
\text { injection, } h\end{array}$ & $\begin{array}{c}\text { Pumping rate, } \\
\text { L/min }\end{array}$ \\
\hline $02 / 10 / 95$ & 1400 & 0 & 76 \\
\hline $02 / 12 / 95$ & 0900 & 43 & 68 \\
\hline $02 / 14 / 95$ & 0845 & 90.75 & 57 \\
\hline $02 / 16 / 95$ & 1500 & 145 & 45 \\
\hline $02 / 18 / 95$ & 1630 & 194.5 & 38 \\
\hline $02 / 24 / 95$ & 1200 & 334 & 30 \\
\hline $03 / 15 / 95$ & 1630 & 794.5 & 30 \\
\hline
\end{tabular}

\subsection{Tracer Test Results}

The sampling strategy consisted of automated sampling of the horizontal extraction well and selected sampling of the piezometers. All of the 5-cm (2-in.) piezometers were sampled each day. Additional sampling focused initially on piezometers immediately adjacent to the horizontal injection well and then concentrated on piezometers that detected the arrival of the tracers. The goal of the piezometer sampling was to determine the arrival peak of the tracers at each location as definitively as possible. 
The horizontal-extraction-well and piezometer breakthrough curves for the bromide tracer are presented in Figs. 6.2 and 6.3. Muck et al. (1996) presents a complete tabulation of the bromide data. A brief description of individual piezometer characteristics, time when peak concentrations of bromide occurred, and descriptions of peak characteristics are presented in Table 6.1.

The terms sharp and broad peaks refer to the amount of time for the initial slug of bromide tracer to move past the piezometer. The broader the peak, the more influence dispersion and diffusion had on the transport of the tracer. The main flow field refers to the area directly between the horizontal recirculation wells.

\subsubsection{Horizontal Extraction Well Results}

An inspection of the bromide data from the horizontal extraction well yields several interesting observations. These include the initial breakthrough of bromide tracer, the initial peak in concentration, repeated peaks in bromide concentration, and the general downward trend in bromide concentration as a function of time. Bromide was detected in the horizontal extraction well $21 \mathrm{~h}$ after injection. This breakthrough time is significantly shorter than could be accounted for by the average permeability of the Gallia member between the horizontal wells even considering the high values of dispersivity.

The initial peak in bromide concentration, which represents the average bulk groundwater flow, occurred after 2.6 days. Once again, this value indicates a groundwater velocity higher than predicted by hydraulic values from pumping tests. Numerous peaks occurred after the initial peak. Although the accuracy of the bromide measurements is estimated to be $\pm 1 \mathrm{ppm}$, data averaging supports the cyclic trend. The first three peaks occurred after a similar volume of water had passed between the wells. Volume is a better indicator than time of the recurrence interval of bromide peaks since the pumping rate was changed during the test. After the first three peaks, the trend became less well-defined. These secondary peaks appear to be additional breakthrough curves as the tracer was being recirculated.

After the initial breakthrough, bromide concentrations in the horizontal extraction well ranged from 8 to $14 \mathrm{ppm}$ for the duration of the tracer test. Since this water was reinjected into the horizontal injection well, this range of bromide concentrations represents background values in the region of the saturated zone influenced by the horizontal well recirculation system.

Throughout the remainder of this section, the term background concentrations will refer to bromide concentrations of water reinjected into the horizontal recirculation system after the initial breakthrough peak.

Finally, bromide concentrations declined with time during the test. This decline could reflect losses due to diffusion or to bromide escaping from the system. As tracers migrated through the more-permeable portions of the Gallia, a portion of the mass was lost by diffusion into adjacent zones of lower permeability. Escape of tracer from the recirculation flow field is 
Extraction Well

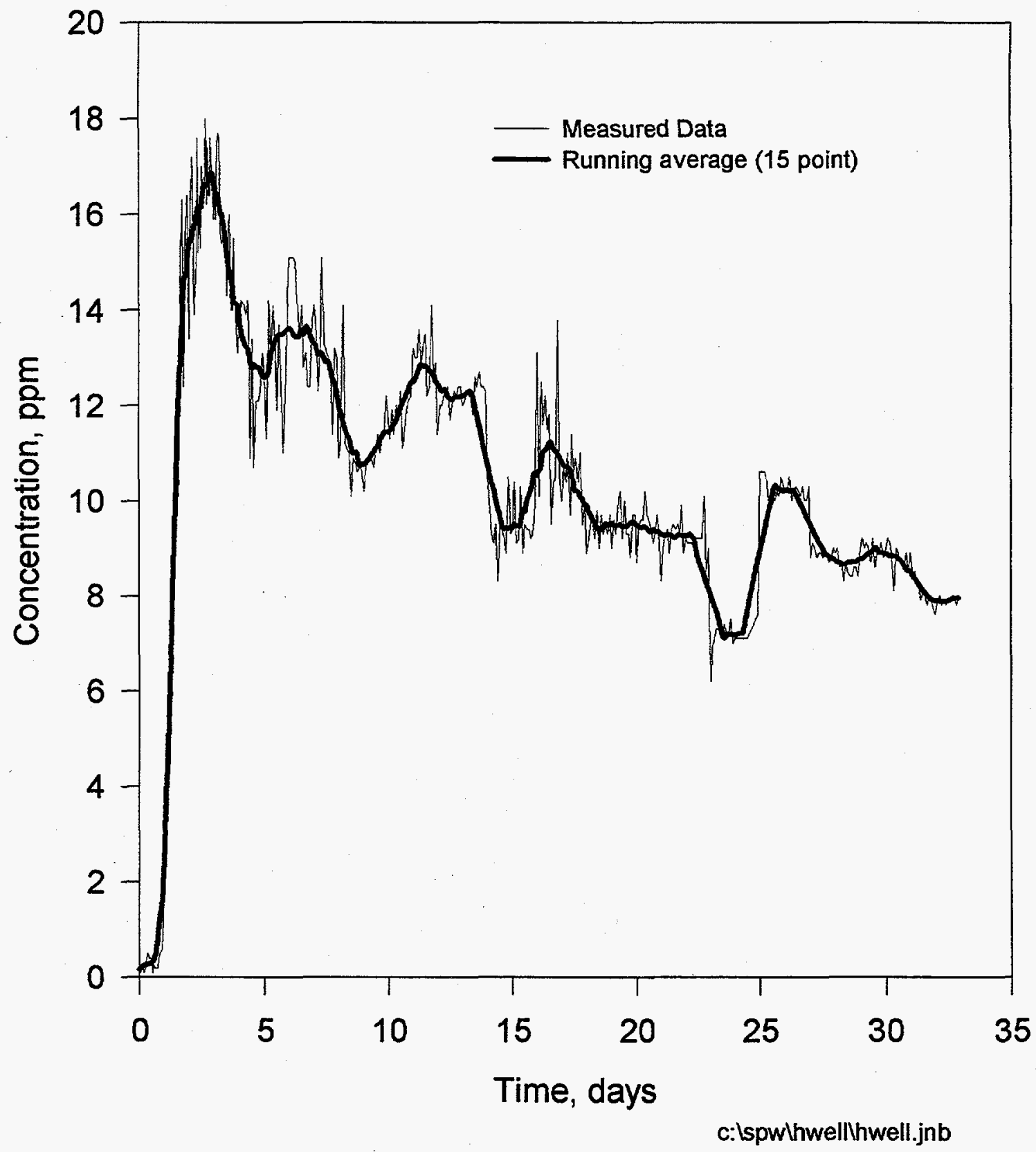

Fig. 6.2. Bromide concentrations from the horizontal extraction well during the tracer test. 


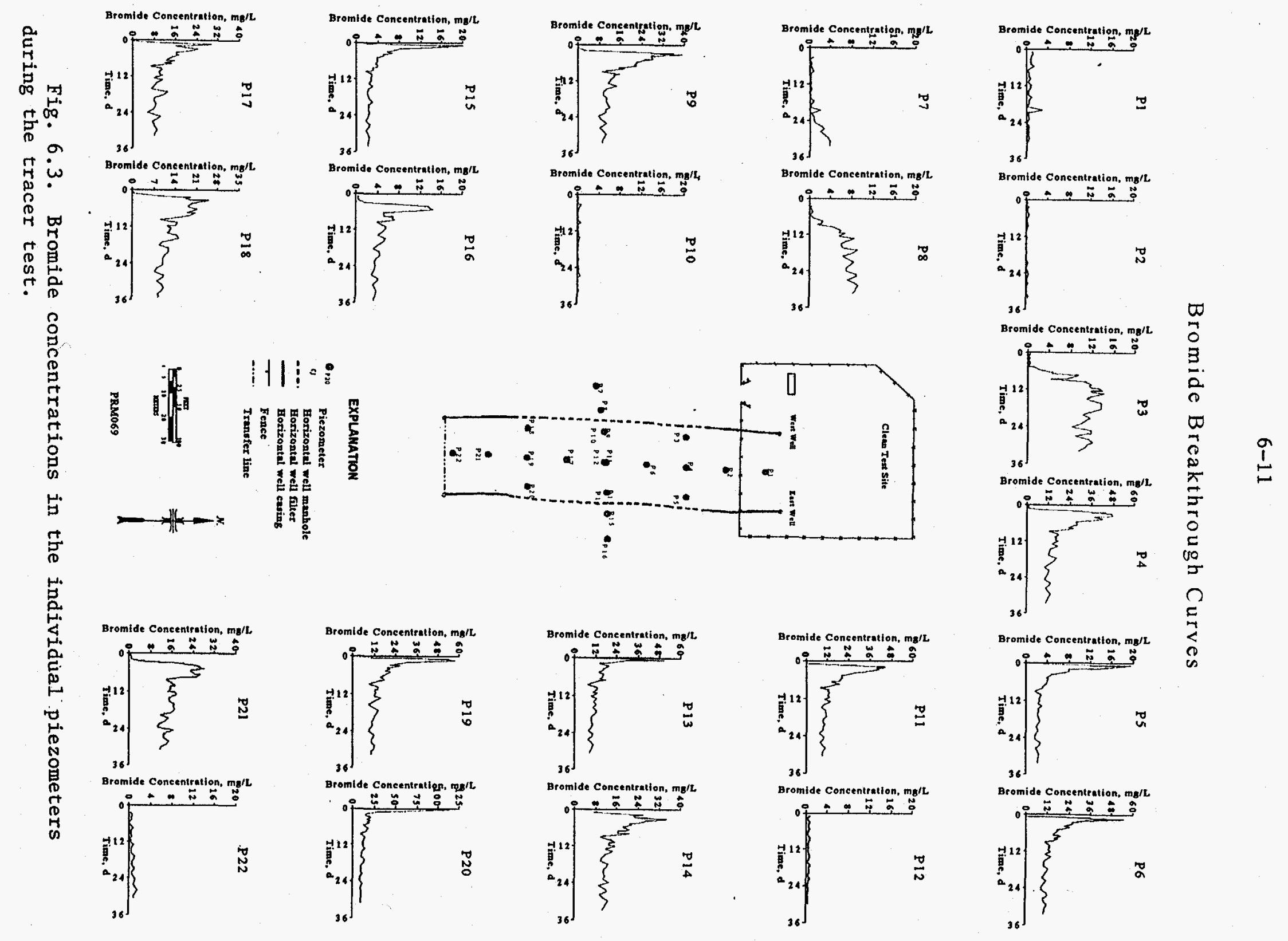


also possible. The amount of water captured on the upgradient side of the horizontal well recirculation system is lost on the downgradient side to maintain a mass balance. Consequently, some of the tracer was lost on the downgradient side of the flow field.

\subsubsection{Gallia Member Piezometer Results}

Sampling data from piezometers completed in the Gallia yielded information on the rate and extent of tracer movement between the horizontal wells. The goal of the piezometer sampling was to assess the uniformity with which the tracer moved in the Gallia and to estimate the degree of heterogeneity in the Gallia. Based on the bromide data from the piezometers, the following statements can be made about the behavior of tracer in the Gallia member:

- Piezometers showed different breakthrough characteristics, indicating heterogeneity in the Gallia.

- Sharp breakthrough peaks were observed, followed by a relatively large decrease in bromide concentrations for piezometers near the injection well compared with downgradient piezometers.

- Sharp breakthrough peaks were observed for piezometers in the more-permeable portions of the Gallia.

- Secondary peaks similar to those observed in the horizontal extraction well were not evident in the piezometers.

- After initial breakthrough peaks occurred, bromide concentrations declined to background values of 8 to $14 \mathrm{ppm}$ for all piezometers where bromide was detected.

- Some piezometers showed no indication of the tracers.

- Breakthrough was observed in all Gallia piezometers located in the area between the ends of the well filters (the main flow field).

Figure 6.4 displays breakthrough times based on bromide analysis for the individual piezometers. These data show the tracer moving at a higher rate near the center of the extraction well. This flow pattern is consistent with preferential flow patterns identified using single-well hydraulic tests. On the other hand, the piezometers do not identify the preferential flow zone responsible for the tracer detected in the horizontal extraction well less than one day after injection. This evidence suggests that preferential flow zones are limited in extent and, therefore, not easily detected by the piezometers. However, large flow zones with higher than average hydraulic conductivities are present and are defined by the piezometers.

Sharp breakthrough peaks in the piezometers adjacent to the horizontal injection well were expected because of the limited time available for hydrodynamic dispersion and diffusion to spread and dilute the tracer. PZ-20 showed a sharp peak that rapidly dropped off to a bromide concentration that was approximately an order of magnitude lower that the peak 


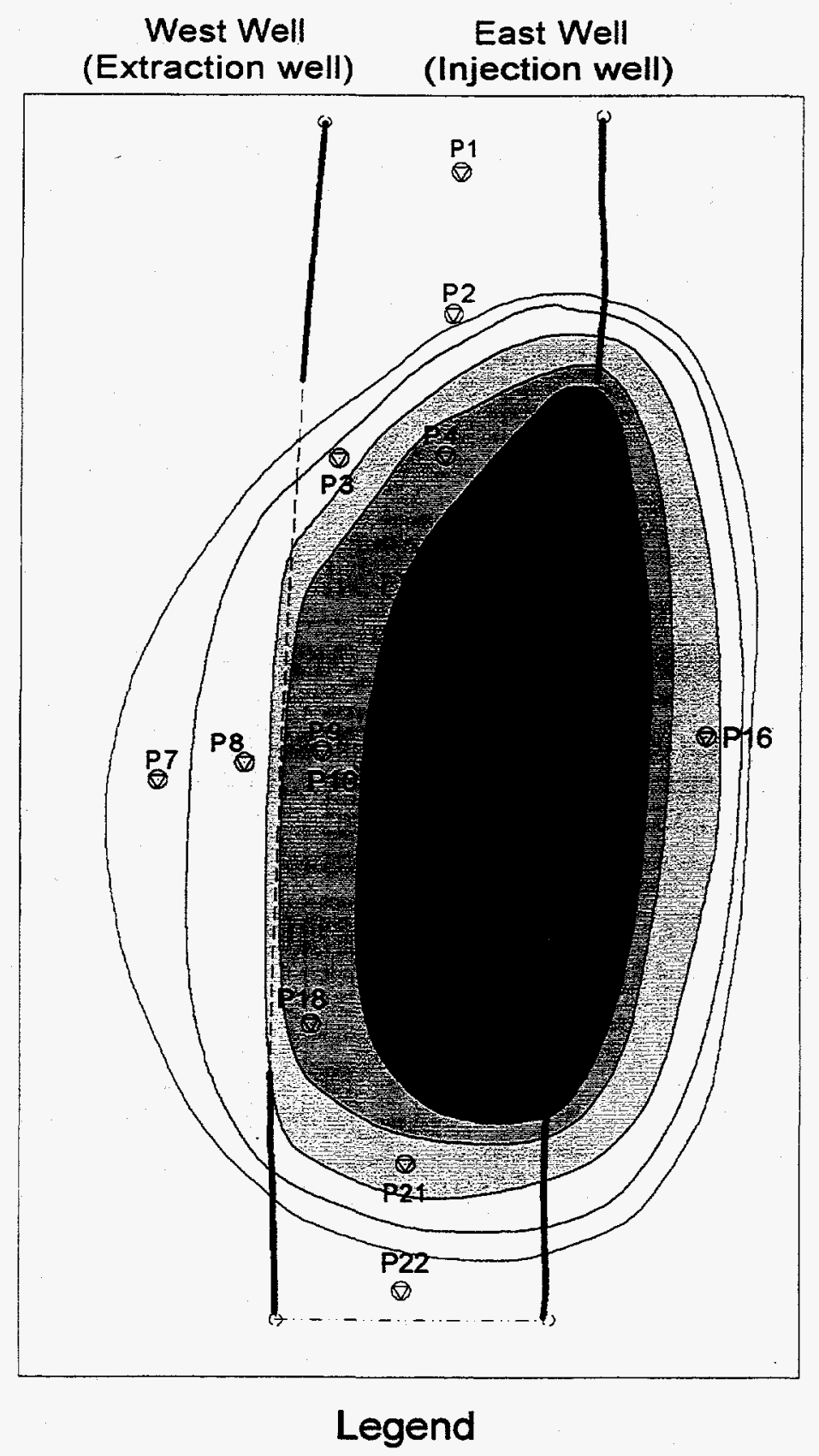

\section{Breakthrough time Piezometers}

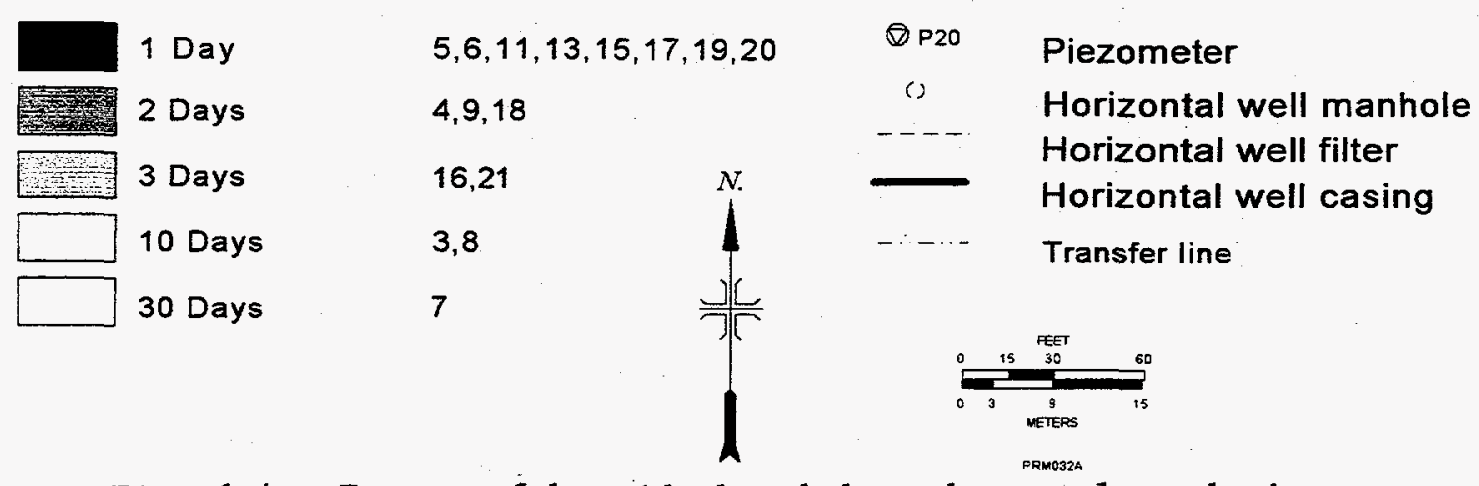

Fig. 6.4. Extent of bromide breakthrough at selected time intervals. 
concentration. However, as the tracer moved farther along the flow path toward the horizontal extraction well, peak bromide concentrations decreased as dispersion and diffusion became more important. This was evident in piezometers near the horizontal extraction well. For example, PZ-18 showed an initial peak of only twice the background bromide concentration.

Sharp breakthrough peaks were observed for piezometers located within the higherpermeability zones of the Gallia defined by Fig. 5.1 in Sect. 5.4. Peak bromide concentrations in these wells ranged from 3 to 10 times higher than background values. The sharp breakthrough peaks are attributed to the minimal time available for hydrodynamic dispersion and diffusion to spread and dilute the tracer in the zones of higher permeability. Outside of the permeable zones, broader breakthrough peaks of lower bromide concentrations were typical.

Tracers were not detected in PZ-01 and PZ-02, indicating that the recirculation flow field does not impact the north of the horizontal well filters. This area yielded hydraulic conductivity vales that did not exceed $7 \times 10^{-5} \mathrm{~cm} / \mathrm{s}(0.2 \mathrm{ft} / \mathrm{d})$. As expected, low permeability sediments greatly reduce the movement of the tracers. Conversely, tracers did reach PZ-21, but not PZ-22. Comparing the hydraulic conductivities of piezometers beyond the south end of the horizontal well filters, PZ-21 yielded the highest value, showing the effect of permeability control on tracer movement in this region.

The bromide concentration curve for PZ-03 is of particular interest. This piezometer is beyond the permeable zone defined by the single-well test and discussed in Sect. 5.4. Nearly 7 days were required for the tracer to reach this piezometer compared with 3 to 4 days for other piezometers located at the same distance from the injection well (PZ-09 and PZ-18). Once the bromide tracer reached PZ-03, concentrations ranged from approximately 8 to 14 ppm. Both PZ-09 and PZ-18 showed bromide peaks that exceeded background values. Since bromide concentrations in PZ-03 equaled background values instead of displaying the sharp peaks typical of advection-dominated flow, this evidence suggests that diffusion controlled the movement of bromide tracer in the lower-permeability area surrounding PZ-03.

\subsubsection{Minford Member Piezometer Results}

PZ-14 and PZ-32 were the only Minford piezometers that showed detections of bromide. The reason $\mathrm{PZ}-14$ showed bromide appears to be due to both a sand zone noted in the geologic $\log$ that is not typical of the Minford at other locations and the nearness of PZ-14 to the horizontal injection well. PZ-32 is located closer to the injection well (1.5 m) than PZ-14; however, no geologic log is available for this piezometer. The lack of bromide in the remaining Minford piezometers across the test site indicates that this unit is not in direct 
hydraulic communication with the underlying Gallia. This lack of hydraulic communication is the direct result of the low permeability of the Minford. Although the Minford can yield minor amounts of water as shown by the pumping analyses, advection-dominated flow is not typical in this member.

\subsubsection{Test Results for the 2.5-cm-diameter Piezometers}

As noted earlier, the installation and construction of the $2.5-\mathrm{cm}$ (1-in.) piezometers differed from the larger 5-cm (2-in.) piezometers, which could bias test results. Of the 11 smalldiameter piezometers, bromide tracer was detected in only PZ-30, PZ-31, and PZ-32. These piezometers are all located $1.5 \mathrm{~m}(5 \mathrm{ft})$ from the injection well. PZ-30 and PZ-31 are completed in the upper portion of the Gallia, while PZ-32 is in the Minford. The proximity of these piezometers to the injection well explains the presence of the tracer.

Three of the 2.5-cm (1-in.) piezometers near the horizontal extraction well (PZ-23, PZ-25, and PZ-26) are completed in the upper $0.5 \mathrm{~m}(1.6 \mathrm{ft})$ of the Gallia member. None showed detections of bromide tracer. There are three possibilities to explain the absence of tracer in these piezometers. First, the piezometers are located in low-permeability portions of the Gallia. This explanation seems unlikely since all 5-cm (2-in.) piezometers between the recirculation wells yielded tracer. The second possibility is that within the Gallia member, the lower portion is a preferential flow zone. This explanation is complicated by the third possibility that the $2.5-\mathrm{cm}$ (1-in.) piezometers are not in as direct hydraulic communication with the Gallia as are the 5-cm (2-in.) piezometers.

\subsection{Colloidal Borescope Measurements}

The colloidal borescope was placed in several piezometers to measure the impact of the horizontal well recirculation system on groundwater flow velocities. A detailed description of the colloidal borescope is presented by Kearl et al. (1994). Briefly, using the colloidal borescope, it is possible to obtain a direct measurement of groundwater velocity without relying on a Darcian solution.

The colloidal borescope was used to quantify groundwater flow velocities during the tracer tests. Flow rates and directions were measured in the majority of the $5-\mathrm{cm}(2-\mathrm{in}$.) piezometers. Measurement results for selected piezometers are presented in Table 6.3 and Appendix G.

The majority of piezometers yielded swirling, nondirectional flow patterns typical of the nonpreferential flow zones that have been observed at other field sites. Notable exceptions were PZ-06, PZ-09, and PZ-19, which all showed consistent flow velocities in steady flow directions. These piezometers also yielded the highest hydraulic conductivity values observed at the site. Borescope measurements and the hydraulic test results suggest the existence of a preferential flow zone or channel that trends from the north end of the east horizontal well through piezometers PZ-06 and PZ-09 and a second channel from the south end of the east 
Table 6.3. Groundwater velocity measurements in selected piezometers using the colloidal borescope

\begin{tabular}{|c|c|c|}
\hline Piezometer & Direction $^{a}$ (azimuth) & Rate $^{b} \mathrm{~cm} / \mathrm{s}$ \\
\hline \hline PZ-04 & $260^{\circ}$ & 0.0042 \\
\hline PZ-06 & $225^{\circ}$ & 0.037 \\
\hline PZ-09 & $288^{\circ}$ & 0.013 \\
\hline PZ-19 & $295^{\circ}$ & 0.0122 \\
\hline PZ-22 & $340^{\circ}$ & 0.0013 \\
\hline
\end{tabular}

${ }^{a}$ Zero azimuth was set to true north.

${ }^{b}$ Flow rates have been corrected for the influence of the wellbore and screen pack.

horizontal well through piezometers PZ-19 and PZ-09. For all of the piezometers listed in Table 6.3, groundwater flow velocities that were observed with the colloidal borescope exceeded calculated values based on measured hydraulic values and Darcy's Law.

\subsection{Discussion}

Several factors influenced the horizontal recirculation tracer test. These factors included heterogeneity or preferential flow zones in the Gallia, recirculation of tracers at lower concentrations than the initial slug, the escape of tracers from the downgradient side of the recirculation flow field, and retardation of the tracers. Tracers that migrate along preferential flow zones can reenter the injection well and reach the extraction well before tracers in a slower flow zone reach the extraction well for the first time. Consequently, a breakthrough curve for the horizontal extraction well may consist of several superimposed breakthrough curves.

An important goal of the tracer test was to determine the influence of aquifer heterogeneity on possible source-remediation strategies. Heterogeneity exerts an important influence on the distribution and concentration of the tracers. Consequently, measuring the arrival and concentration of tracers at specified locations in the region between the horizontal wells can provide insight into the efficiency of a dual-well horizontal recirculation system in remediating discrete contaminant source areas.

Bromide was detected in 16 of the 195 -cm (2-in.) diameter piezometers completed in the Gallia. These 16 piezometers include all of the piezometers located between the horizontal well filters and those piezometers located upgradient and downgradient of the horizontal well filters. The three piezometers in which bromide was not detected are located north of the north end (PZ-01 and PZ-02) and south of the south end (PZ-22) of the horizontal well filters. The presence of bromide in the remaining 16 piezometers indicates that the flow field 
established by the horizontal well recirculation system was thoroughly penetrated by the bromide tracer.

Arrival times for the tracers differed significantly from one piezometer to another. This is attributed to the distance from the injection well and varying hydraulic conductivity values discussed in the previous section. Advection-dominated transport was apparent in areas immediately downgradient of the horizontal injection well and in zones of higher permeability between the wells. In the zones of lower permeability, the effects of dispersion and diffusion increased as the distance from the injection well increased.

Not all of the 2.5-cm (1-in.) piezometers completed in the Gallia member showed tracers. None of the 2.5-cm (1-in.) piezometers near the horizontal extraction well showed detections of bromide. These piezometers are completed in the Minford and the upper portions of the Gallia. The lack of bromide compared with the 5-cm (2-in.) piezometers may be due to different installation techniques or preferential flow in the lower portions of the Gallia.

The only Minford piezometers where bromide was detected were PZ-14 and PZ-32. The lithologic log for PZ-14 shows a sandy lens in the Minford at this location. It is assumed that this sandy lens is in hydraulic connection with the horizontal injection well that is only $5 \mathrm{~m}$ $(15 \mathrm{ft})$ from PZ-14. This sandy lens is not typical in other piezometers completed in the

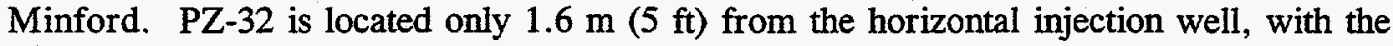
screened interval immediately above the Gallia member. Because bromide was found in only two of the Minford piezometers, it appears that contamination present in the Minford member at other PORTS locations would not be significantly impacted by a horizontal well recirculation system.

Comparing colloidal borescope velocity measurements with tracer test results provides some interesting relationships. The tracer test showed that bromide reached the extraction well 21 $h$ after being introduced into the injection well. Using the highest observed hydraulic conductivity for the entire facility of $1.8 \times 10^{-2} \mathrm{~cm} / \mathrm{s}(50 \mathrm{ft} / \mathrm{d})$, an assumed porosity of 0.20 , and neglecting dispersion, it would take 2.6 days for the tracer to reach the extraction well. However, the velocity measured in PZ-06 of $0.037 \mathrm{~cm} / \mathrm{s}(105 \mathrm{ft} / \mathrm{d})$ yields an initial breakthrough resulting from preferential flow zones of approximately $23 \mathrm{~h}$, similar to the time measured by the tracer.

If the velocities of 0.0122 and $0.013 \mathrm{~cm} / \mathrm{s}$ (35 and $37 \mathrm{ft} / \mathrm{d}$ ) measured in PZ-19 and PZ-09 represent the average seepage velocity in the area between the recirculation wells under pumping conditions, this would result in a predicted breakthrough time of approximately 2.8 days. This value is in excellent agreement with the first bromide peak in the horizontal extraction well of approximately 2.6 days. 


\section{Elution Test}

\subsection{Introduction}

A bromide-elution test was performed at the CTS as a follow-on to the bromide tracer test. The purpose of the elution test was to observe the removal of bromide tracer from the recirculation flow field with time. The injection and extraction wells were operated for 20 days. The initial flow rate was $8 \mathrm{gal} / \mathrm{min}(1,820 \mathrm{~L} / \mathrm{h})$ for 12 days, but due to continued well clogging, the flow rate was reduced to $6 \mathrm{gal} / \mathrm{min}(1,360 \mathrm{~L} / \mathrm{h})$ for the last 8 days. To elute bromide from the flow field, clean water from a nearby fire hydrant was routed to the injection well, and groundwater from the extraction well was discharged to ground surface in a nearby drainage swale.

Groundwater samples for bromide analysis were collected from the extraction well and piezometers PZ-01 through PZ-22 (Fig. 7.1). Section 6.2.1 describes the bromide tracer, Sect. 6.4.1 describes the equipment and methods used for field analysis of water samples for bromide concentration, and Sect. 6.5.2 describes the water sampling methodology. Muck et al. (1996) presents a complete tabulation of the bromide data. The accuracy of the bromide measurements is estimated to be $\pm 1 \mathrm{mg} / \mathrm{L}$, so analytical results discussed in the text are rounded to the nearest whole number. Plots of bromide concentration vs time were prepared to show the removal rate of bromide (Figs 7.1 and 7.2). Water samples for bromide analysis were also collected from the fire hose during the test to monitor the concentration of bromide in the injected water (Fig: 7.3). Table 7.1 summarizes observations of bromide concentrations in water samples from the piezometers.

For the first $\mathbf{1 2}$ days of the elution test, water samples were collected daily from the injection water, daily from PZ-01 through PZ-22, and every two hours from the extraction well. Note that the elution test was not in the original scope of work for this project and was performed using available personnel. For the last eight days of the elution test, personnel were not available on a daily basis to collect water samples, so no samples were collected from the injection water or the piezometers. Instead, an auto sampler collected water samples once every eight hours from the extraction well.

\subsection{Elution Test Results}

The fire-hydrant source of injection water contained a bromide concentration of 1 to $2 \mathrm{mg} / \mathrm{L}$ (Fig. 7.3). This is considered the background concentration of bromide when interpreting the elution test results. Several trends that were noted in the tracer test results are also evident in the elution test results:

- The elution rates of the piezometers differ, indicating heterogeneity in the Gallia.

- Consistent with the tracer test results, no bromide was detected in PZ-01 and PZ-02. These piezometers lie north of the horizontal well filters and outside of the main flow field. 

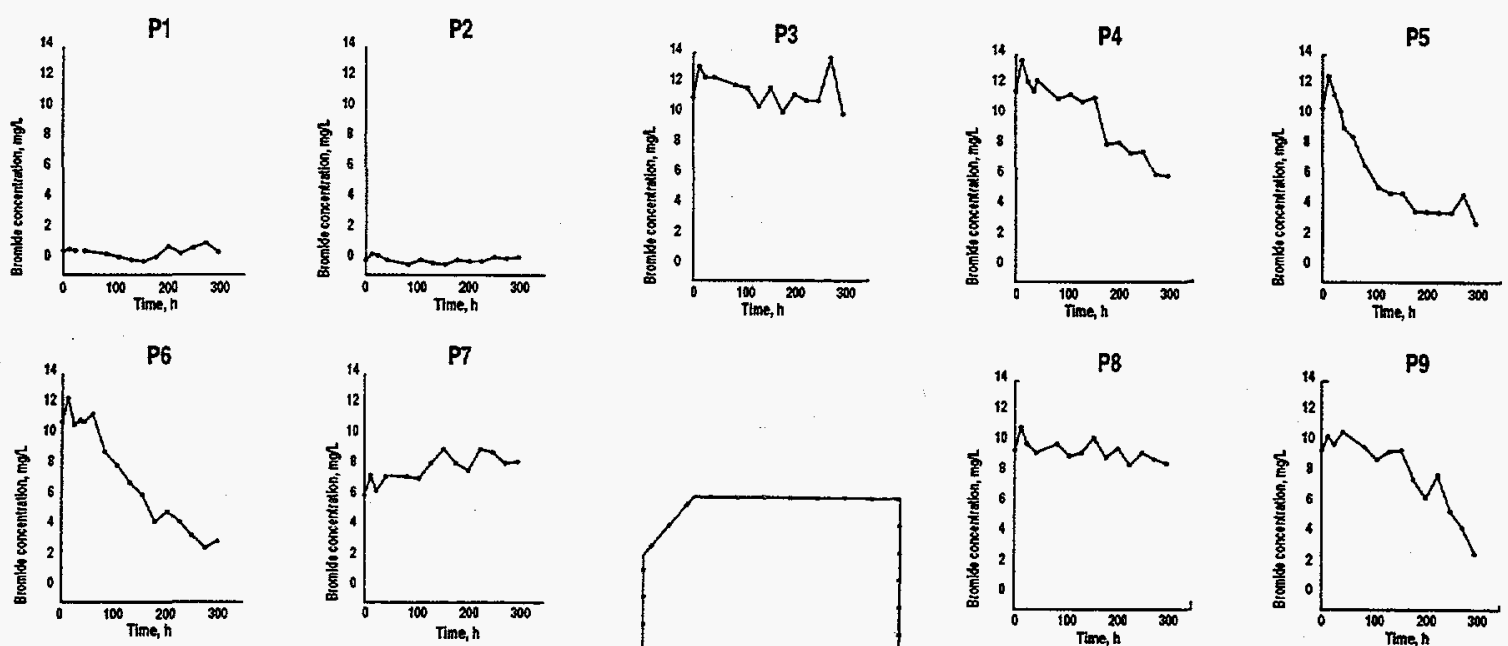

P7
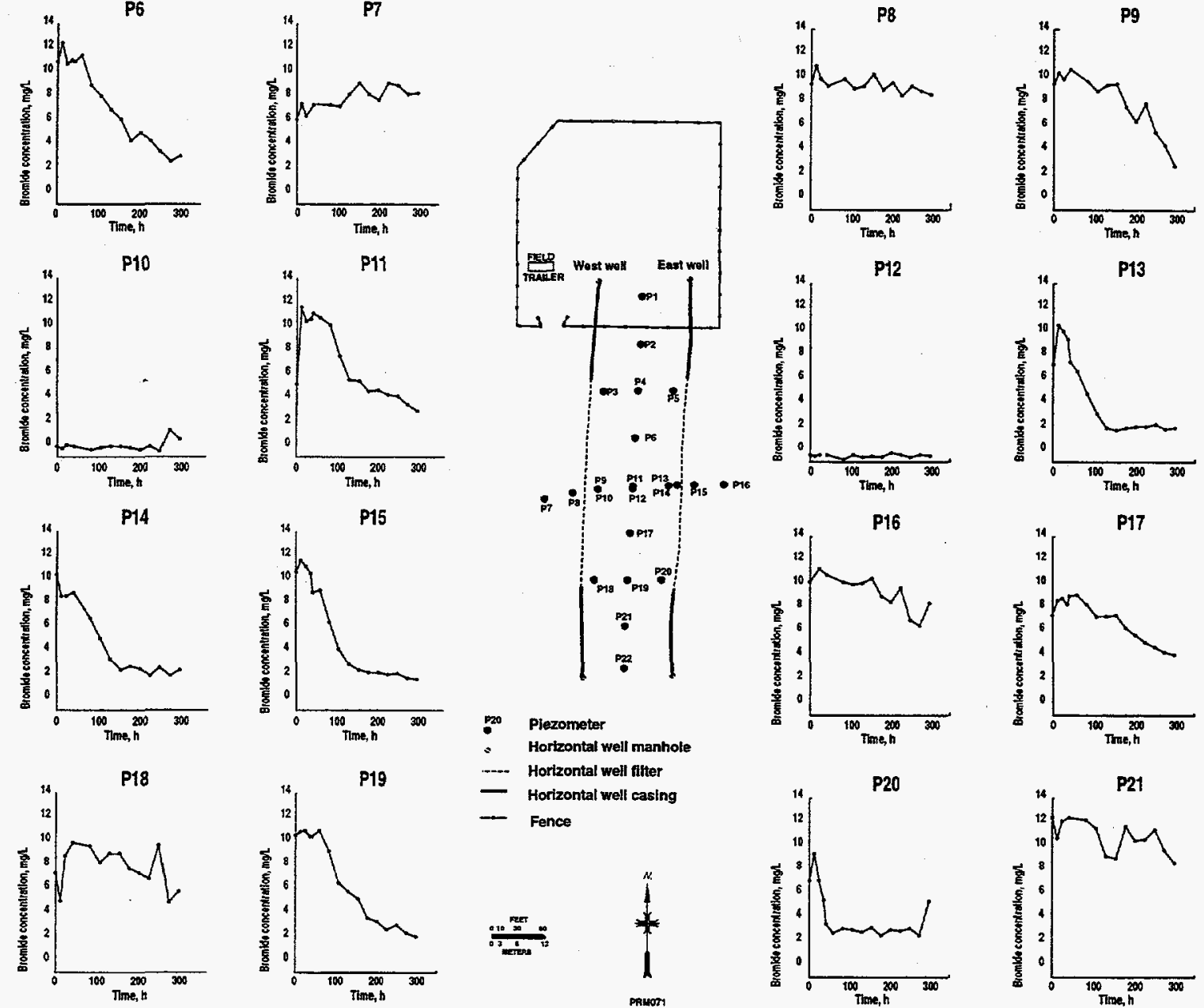

-..- Horizontal well filter

- Horizontal well casing
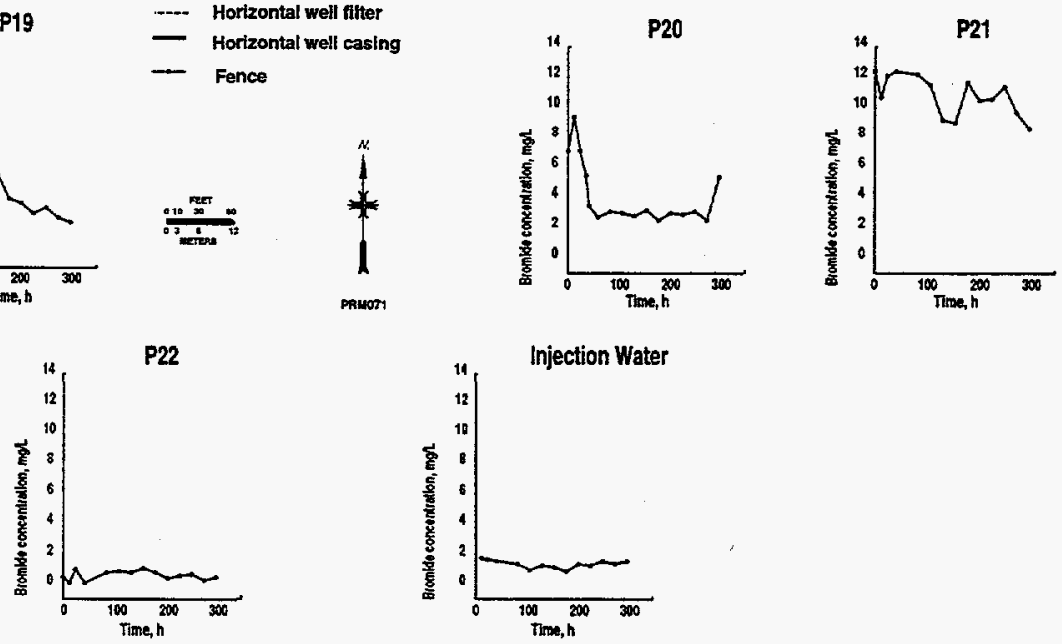

Fig. 7.1. Bromide concentrations in individual piezometers during the elution test. 


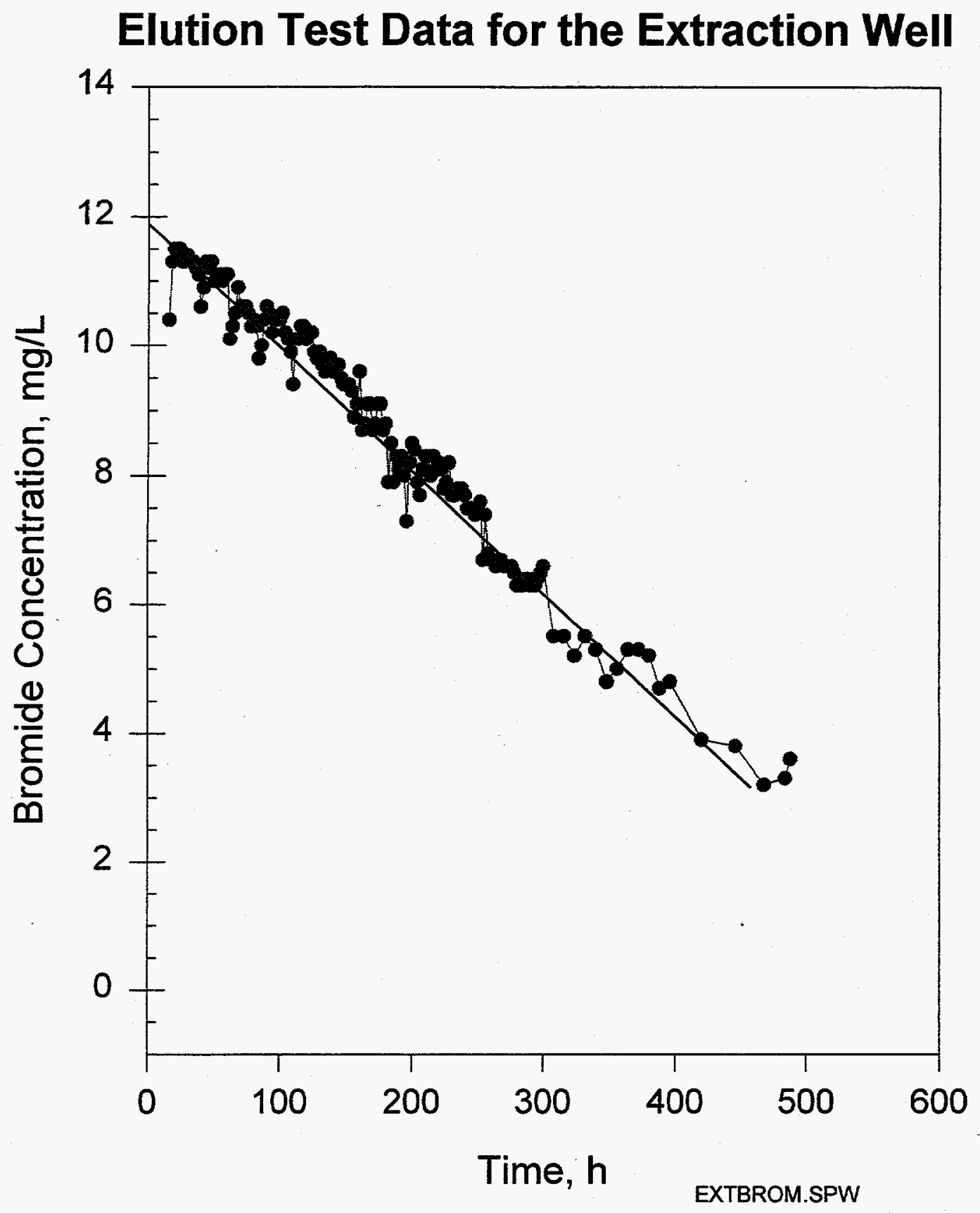

Fig. 7.2. Bromide concentrations in the horizontal extraction well during the elution test. 


\section{Bromide Concentrations in Injection Water During Elution Test}

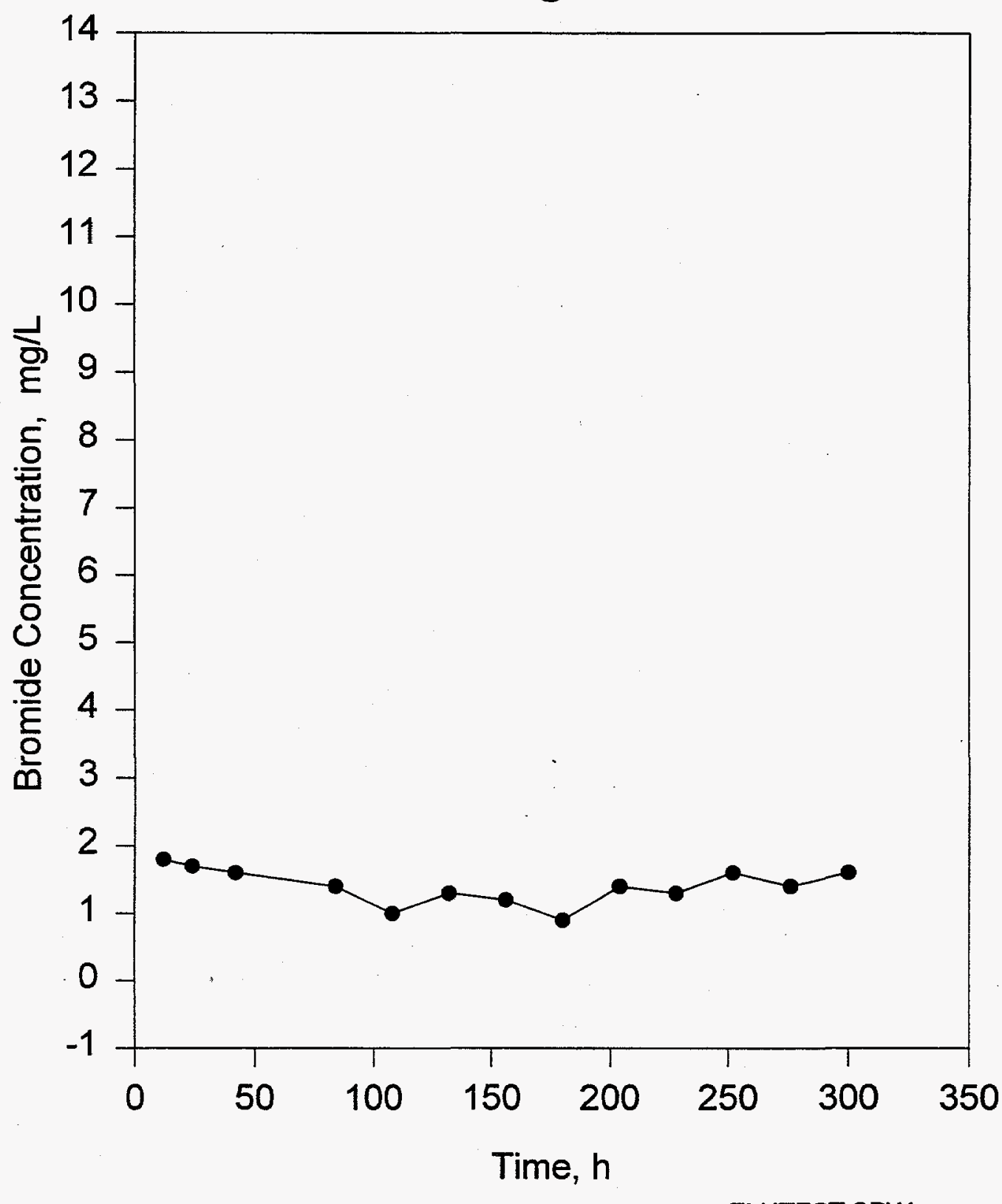

ELUTEST.SPW

Fig. 7.3. Bromide concentrations in the fire-hydrant water during the elution test. 
Table 7.1. Observations of bromide concentrations in piezometers during the elution test

\begin{tabular}{|c|c|c|c|c|c|}
\hline $\begin{array}{l}\text { Piezometer } \\
\text { number }\end{array}$ & Formation & $\begin{array}{c}\text { Average } \\
\text { hydraulic K, } \\
\mathrm{cm} / \mathrm{s}\left(\times 10^{-4}\right)\end{array}$ & $\begin{array}{l}\text { Initial } \mathbf{B r}^{-} \\
\mathbf{m g} / \mathbf{L}\end{array}$ & $\begin{array}{l}\text { Final Br- } \\
\text { mg/L }\end{array}$ & Comments \\
\hline PZ-01 & G & 0.52 & 1 & 1 & No initial $\mathrm{Br}^{-}$; no change during test \\
\hline PZ-02 & $\mathrm{G}$ & 0.28 & 0 & 0 & No initial $\mathrm{Br}^{-}$; no change during test \\
\hline PZ-03 & $\mathrm{G}$ & 3.5 & 11 & 10 & Little, if any, decrease in $\mathrm{Br}^{-}$ \\
\hline $\mathrm{PZ}-04$ & $\mathrm{G}$ & 10 & 12 & 6 & Moderate decrease in $\mathrm{Br}^{-}$(from 12 to $6 \mathrm{mg} / \mathrm{L}$ in 12 days) \\
\hline PZ-05 & G & 9.0 & 11 & 3 & $\begin{array}{l}\text { Rapid decrease in } \mathrm{Br}^{-} \text {(from } 11 \text { to } 5 \mathrm{mg} / \mathrm{L} \text { in four days), then slow decrease in } \\
\mathrm{Br}^{-} \text {(from } 5 \text { to } 3 \mathrm{mg} / \mathrm{L} \text { in eight days) }\end{array}$ \\
\hline PZ-06 & $\mathbf{G}$ & 36 & 11 & 3 & $\begin{array}{l}\text { Rapid decrease in } \mathrm{Br}^{-} \text {(from } 11 \text { to } 3 \mathrm{mg} / \mathrm{L} \text { in ten days), then constant } \mathrm{Br}^{-} \text {at } \\
3 \mathrm{mg} / \mathrm{L}\end{array}$ \\
\hline PZ-07 & $\mathrm{G}$ & 5.5 & 6 & 8 & Slight increase in $\mathrm{Br}^{-}$ \\
\hline PZ-08 & $\mathrm{G}$ & 9.7 & 10 & 9 & Little, if any, decrease in $\mathrm{Br}^{-}$ \\
\hline PZ-09 & $\mathrm{G}$ & 56 & 10 & 3 & $\begin{array}{l}\text { A delay of three days, followed by moderate decrease in } \mathrm{Br}^{-} \text {(from } 10 \text { to } 3 \mathrm{mg} / \mathrm{L} \\
\text { in nine days) }\end{array}$ \\
\hline PZ-10 & $\mathbf{M}$ & 0.20 & 0 & 1 & No initial $\mathrm{Br}^{-}$; no change during test \\
\hline PZ-11 & G & 0.069 & $12^{a}$ & 3 & $\begin{array}{l}\text { Rapid decrease in } \mathrm{Br} \text { (from } 12 \text { to } 5 \mathrm{mg} / \mathrm{L} \text { in seven days), then slow decrease in } \\
\mathrm{Br}^{-} \text {(from } 5 \text { to } 3 \mathrm{mg} / \mathrm{L} \text { in five days) }\end{array}$ \\
\hline $\mathrm{PZ}-12$ & M & 0.32 & 0 & 0 & No initial $\mathrm{Br}^{-}$; no change during test \\
\hline $\mathrm{PZ}-13$ & $\mathbf{G}$ & 3.5 & 7 & 2 & $\begin{array}{l}\text { Rapid decrease in } \mathrm{Br}^{-} \text {(from } 11 \text { to } 2 \mathrm{mg} / \mathrm{L} \text { in five days), then constant } \mathrm{Br}^{-} \text {at } \\
2 \mathrm{mg} / \mathrm{L}\end{array}$ \\
\hline
\end{tabular}


Table 7.1. (continued)

\begin{tabular}{|c|c|c|c|c|c|}
\hline $\begin{array}{l}\text { Piezometer } \\
\text { number }\end{array}$ & Formation & $\begin{array}{c}\text { Average } \\
\text { hydraulic K, } \\
\mathrm{cm} / \mathrm{s}\left(\times \mathbf{1 0}^{-4}\right) \\
\end{array}$ & $\begin{array}{l}\text { Initial } \mathbf{B r}^{-} \\
\quad \mathbf{m g} / \mathbf{L}\end{array}$ & $\begin{array}{l}\text { Final Br- } \\
\mathbf{m g} / \mathbf{L}\end{array}$ & Comments \\
\hline PZ-14 & $\mathbf{M}$ & 0.21 & 10 & 2 & $\begin{array}{l}\text { Rapid decrease in } \mathrm{Br}^{-} \text {(from } 10 \text { to } 3 \mathrm{mg} / \mathrm{L} \text { in five days), then fairly constant } \mathrm{Br}^{-} \\
\text {at } 2 \text { to } 3 \mathrm{mg} / \mathrm{L}\end{array}$ \\
\hline $\mathrm{PZ}-15$ & G & 0.41 & 11 & 2 & $\begin{array}{l}\text { Rapid decrease in } \mathrm{Br}^{-} \text {(from } 11 \text { to } 2 \mathrm{mg} / \mathrm{L} \text { in six days), then constant } \mathrm{Br}^{-} \text {at } \\
2 \mathrm{mg} / \mathrm{L}\end{array}$ \\
\hline PZ-16 & $\mathbf{G}$ & 4.6 & 10 & 8 & Slow decrease in $\mathrm{Br}^{-}$(from 10 to $8 \mathrm{mg} / \mathrm{L}$ in 12 days) \\
\hline $\mathrm{PZ}-17$ & G & 32 & 7 & 4 & Slow decrease in $\mathrm{Br}^{-}$(from 7 to $4 \mathrm{mg} / \mathrm{L}$ in 12 days) \\
\hline PZ-18 & G & 3.5 & 7 & 6 & Little, if any, decrease in $\mathrm{Br}^{-}$ \\
\hline PZ-19 & $\mathrm{G}$ & 39 & 11 & 2 & $\begin{array}{l}\text { A delay of one day, followed by a rapid decrease in } \mathrm{Br}^{-} \text {(from } 11 \text { to } 3 \mathrm{mg} / \mathrm{L} \text { in } \\
\text { seven days), then a slow decrease in } \mathrm{Br}^{-} \text {(from } 3 \text { to } 2 \mathrm{mg} / \mathrm{L} \text { in four days) }\end{array}$ \\
\hline PZ-20 & G & 11 & 7 & 5 & $\begin{array}{l}\text { Rapid decrease in } \mathrm{Br}^{-} \text {(from } 7 \text { to } 3 \mathrm{mg} / \mathrm{L} \text { in three days), then constant } \mathrm{Br}^{-} \text {at } \\
3 \mathrm{mg} / \mathrm{L} \text { (except for last sample, at } 5 \mathrm{mg} / \mathrm{L} \text { ) }\end{array}$ \\
\hline $\mathrm{PZ}-21$ & G & 2.6 & 12 & 9 & Slow decrease in $\mathrm{Br}^{-}$(from 12 to $9 \mathrm{mg} / \mathrm{L}$ in 12 days) \\
\hline $\mathrm{PZ}-22$ & G & 1.5 & 1 & 1 & No initial $\mathrm{Br}^{-}$; no change during test \\
\hline
\end{tabular}

$\mathbf{G}=$ Gallia

$M=$ Minford

${ }^{a}=\quad$ The second groundwater sample from PZ-11 with a bromide concentration of $12 \mathrm{mg} / \mathrm{L}$ is considered more representative of initial conditions than the first groundwater sample with a bromide concentration of $5 \mathrm{mg} / \mathrm{L}$.

Note: The fire-hydrant source of injection water during the elution test contained a bromide concentration of 1 to $2 \mathrm{mg} / \mathrm{L}$. This is considered the background bromide concentration when interpreting the elution test results. 
- Of the three piezometers close to the extraction well and within the flow field between the wells (PZ-03, PZ-09, and PZ-18), a much greater elution of bromide was observed in PZ-09. Little, if any, decrease in bromide concentrations occurred in PZ-03 and PZ-18. These observations are consistent with the tracer test results that indicated a preferential flow zone in the area of PZ-09 and a low-flow zone in the area of PZ-03.

- The moderate to rapid decreases in bromide concentrations in PZ-04, PZ-05, PZ-06, PZ-09, PZ-19, and PZ-20 are consistent with the relatively high hydraulic conductivity values determined from these piezometers (Table 7.1) and the preferential flow zones discussed in Sect. 6.

- Little, if any, decrease in bromide concentration occurred in PZ-08. This observation is consistent with the observation during the tracer test that this piezometer lies outside of the main flow field. Changes in bromide concentrations in this area are diffusion controlled.

- Consistent with the tracer test observations, no bromide was observed in the Minford piezometers PZ-10 and PZ-12, indicating that this unit is not in direct hydraulic communication with the underlying Gallia. As with the tracer test, the rapid decrease in bromide concentration in the Minford piezometer PZ-14 is attributed to the unique sand zone noted in the geologic log for this piezometer and the close proximity of PZ14 to the horizontal injection well.

- The rapid decrease in bromide concentrations in PZ-13 and PZ-15 is attributed to the close proximity of these piezometers to the injection well. A rapid response to the injection of tracer was also observed in these piezometers due to the limited time available for hydrodynamic dispersion and diffusion to spread and dilute the tracer (Sect. 6). Changes in bromide concentrations in this area are controlled primarily by advection.

- The slow elution of bromide observed in PZ-16 is consistent with the observation during the tracer test that this piezometer lies outside of the main flow field. Changes in bromide concentrations in this area are diffusion-controlled.

- Consistent with the tracer test results, elution of bromide from PZ-21 occurred slowly, and no bromide was detected in PZ-22. These piezometers lie south of the horizontal well filters and outside of the main flow field. Changes in bromide concentration in the area of PZ-21 are diffusion-controlled.

Final bromide concentrations were in the range of 2 to $3 \mathrm{mg} / \mathrm{L}$ in PZ-05, PZ-06, PZ-09, PZ$11, \mathrm{PZ}-13, \mathrm{PZ}-14, \mathrm{PZ}-15, \mathrm{PZ}-19$, and PZ-20. This range of concentrations is close to the background concentration in the injected water. As described above, these piezometers are located in the preferential flow zones between the wells and the area adjacent to the injection well. Bromide transport was dominated by advection in these areas, such that bromide concentrations during the elution test dropped rapidly to near-background levels. The stabilization of bromide concentrations at 2 to $3 \mathrm{mg} / \mathrm{L}$ in PZ-05, PZ-09, PZ-11, and PZ-19 
indicates a transition to diffusion-dominated transport of bromide in these areas. If no bromide were present in the injected water, further reductions in bromide concentrations would occur slowly over an extended period of time.

Transport of bromide was dominated by diffusion in the areas outside of the preferential flow zones and at a distance from the injection well as shown by the elution test data for PZ-03, PZ-07, PZ-08, PZ-16, PZ-17, PZ-18, and PZ-21. Because bromide elution either occurred slowly or was not evident in these areas, bromide concentrations did not approach background levels during the time period of this test. If the elution test had been of longer duration, it is expected that bromide concentrations would have slowly declined to near-background concentrations in this set of piezometers.

Figure 7.2 presents bromide data for the horizontal extraction well and indicates a trend of decreasing bromide concentration as a function of time. Across the 20-day period of the test, bromide concentrations in the extraction well steadily decreased from an initial concentration of approximately $12 \mathrm{mg} / \mathrm{L}$ to a final concentration of approximately $3 \mathrm{mg} / \mathrm{L}$. Linear regression of the extraction well data using the least squares method yielded the following relationship between bromide concentration and time:

$$
Y=-0.0188 X+11.7
$$

where

$$
\begin{aligned}
& Y=\text { bromide concentration in the extraction well effluent, } \mathrm{mg} / \mathrm{L} \\
& X=\text { time }, \mathrm{h}
\end{aligned}
$$

The correlation coefficient $(r)$ for this data set is -0.987 , indicating a linear relationship between bromide concentration and time. (A perfectly linear relationship would yield $r=$ -1.0 , compared with $r=0.0$ for a non-linear relationship.) This linear relationship suggests that bromide elution from the recirculation flow field was dominated by advection during the time period of the test. If the elution test had been of longer duration, it is expected that bromide concentrations would have gradually stabilized at near-background concentrations of 2 to $3 \mathrm{mg} / \mathrm{L}$ as bromide transport became dominated by diffusion.

This transition from advection- to diffusion-dominated transport is often observed in pumpand-treat groundwater systems and soil-vapor-extraction systems in which contaminant concentrations drop rapidly at first and then slowly with time (U.S. EPA 1989a, 1989b). The transition to diffusion-dominated transport limits the effectiveness of these systems because long-term operation provides only a slight reduction in the remaining contaminant mass. Of interest is the short-term reduction in contaminant mass provided during advection-dominated transport. The mass of bromide removed from the recirculation flow field by advectiondominated transport can be estimated by calculating the area under the line on Fig. 7.2 (units of $\mathrm{mg} / \mathrm{L} / \mathrm{h}$ ) and multiplying by the rate of extraction (units of $\mathrm{L} / \mathrm{h}$ ).

During the first $282 \mathrm{~h}$ of the elution test, the bromide concentration in the extracted groundwater dropped from approximately 12 to $6 \mathrm{mg} / \mathrm{L}$, with a flow rate of $1,820 \mathrm{~L} / \mathrm{h}$ (48 $\mathrm{gal} / \mathrm{h}$ ). During the final $192 \mathrm{~h}$ of the elution test, the bromide concentration in the extracted groundwater dropped from approximately 6 to $3 \mathrm{mg} / \mathrm{L}$, with a flow rate of $1,360 \mathrm{~L} / \mathrm{h}(40$ 
gal $/ \mathrm{h}$ ). The combined mass removal of bromide for the duration of the test was approximately $5.8 \mathrm{~kg}(13 \mathrm{lb})$. From Table 6.1 , the mass of bromide injected into the recirculation flow field during the tracer test was approximately $6.4 \mathrm{~kg}(14 \mathrm{lb})[3,396 \mathrm{mg} / \mathrm{L}$ in a solution volume of $1,890 \mathrm{~L}(50$ gal)]. Using an average bromide concentration of $1.4 \mathrm{mg} / \mathrm{L}$ for the injected fire-hydrant water, approximately $1.1 \mathrm{~kg}(2.4 \mathrm{lb})$ of bromide was injected into the recirculation flow field during the elution test. This gives a total of approximately $7.5 \mathrm{~kg}$ $(16.5 \mathrm{lb})$ of bromide that was injected into the system. By comparing this mass to the mass of bromide removed, the bromide mass reduction during the elution test was approximately $77 \%$.

These calculations suggest that, in the absence of adsorption, approximately three-quarters of a fluid injected into the Gallia will be transported in a timely fashion by advection. One quarter will be lost by diffusion into lower-permeability material or will escape from hydraulic containment. It is likely that diffusive losses would decrease with time as the solution concentration in lower-permeability sediments equilibrated with the solution concentration in the preferential flow zones.

These results also suggest that a horizontal well recirculation system in a contaminated area of the Gallia at PORTS may be capable of extracting $75 \%$ of the dissolved contaminant mass in a short period of time (assuming a recirculation flow system similar to the one at the CTS; a contaminant solute that behaves conservatively, in a manner similar to bromide; and an advection-dominated transport period of approximately one month). As a note of caution, in a groundwater system that is contaminated by dense nonaqueous-phase liquid (DNAPL), the dissolved portion of the contaminant mass typically represents a very small fraction of the total contaminant mass. Mobilization of the DNAPL into the recirculation flow field would be necessary to effect a large reduction in the total contaminant mass. This might be accomplished through the use of surfactants or other methods to increase the proportion of contaminant mass that is dissolved in the contaminated groundwater. 


\section{Development of the Horizontal Wells}

\subsection{Introduction}

As described in Sects. 5.5, 6.6, and 7.1, performance of the extraction well (west horizontal well) deteriorated due to well clogging during long-term operation. The sustainable pumping rate dropped from $76 \mathrm{~L} / \mathrm{min}$ to $23 \mathrm{~L} / \mathrm{min}(20 \mathrm{gal} / \mathrm{min}$ to $6 \mathrm{gal} / \mathrm{min}$ ) during an operating period of 53 days. This decline was due to clogging of the porous filter in the extraction well. No significant pressure increase was observed during the injection of water into the east horizontal well, suggesting that clogging was not a problem for the east horizontal well.

Initially, three possible mechanisms were considered to be responsible for the clogging. These mechanisms included mineral precipitation in the well filter, biofouling due to iron bacteria, and skin effects due to clayey material in the surrounding porous media. Laboratory tests using water pumped through a core section of the Gallia member and a cross section of porous well filter yielded iron oxide deposits. These deposits were analyzed and found to be goethite $(\mathrm{FeO}(\mathrm{OH}))$. Once dried, the geothite precipitate was friable but relatively insoluble. The $\log$ of the equilibrium constant $\left(\mathrm{K}_{\mathrm{eq}}\right)$ for goethite is -42 , indicating a very low solubility (Drever 1988).

During September 1995, water samples were collected from the extraction well and analyzed for bacteria. Iron related bacteria were found to be present in the water samples. These bacteria included klebsiella, pseudomonads, and enterobacter. Well clogging due to iron bacteria is common in the larger water-producing aquifers in the region.

Clogging of the formation surrounding the porous well filter is the remaining mechanism that was considered. Based on recommendations from the porous filter manufacturer, the wells were pumped for development. No mechanical or chemical development was performed on the wells. The concern with the recommended development method is that fines remaining in the formation surrounded the porous well filter and formed a low-permeability skin that reduced the hydraulic efficiency of the horizontal extraction well.

\subsection{Field Program}

During October 1995, field personnel from ORNL-Grand Junction developed the horizontal wells using a water-jetting method. Prior to development, pumping tests were performed on the extraction well to provide a baseline of well performance. The well was pumped at a rate of $38 \mathrm{~L} / \mathrm{min}$ (10 gal/min), and the water level in the horizontal well dropped below the pump intake after $32 \mathrm{~min}$. Following a 3-h recovery period, the well was pumped at a reduced rate of $28 \mathrm{~L} / \mathrm{min}(7.5 \mathrm{gal} / \mathrm{min}$ ) for $72 \mathrm{~min}$ before the water level dropped below the pump intake.

Also prior to development, a borehole video camera was used to inspect the porous well filter and casing in both of the horizontal wells. A frontal mirror on the video camera allowed viewing of the side walls. Another video inspection was performed after the completion of well development to visually assess the effects of well development. 
Based on the laboratory test results, the well development program included both mechanical and chemical treatment. Mechanical development consisted of water jetting and overpumping. Driscoll (1979) presents data that indicate water jetting and overpumping are upwards to $40 \%$ more efficient that other well development methods such as surging. A specially designed eight-nozzle jetting tool with a discharge velocity exceeding $30.5 \mathrm{~m} / \mathrm{s}(100$ $\mathrm{ft} / \mathrm{s}$ ) per nozzle was used to mechanically agitate the porous well filter and the adjacent formation. A submersible pump on the opposite end of the horizontal well was pumped at the maximum allowable rate to remove sediment from the well. Three full days of jetting and overpumping were performed on each of the horizontal wells.

After jetting and overpumping, the horizontal wells were shock chlorinated to kill iron bacteria. Calcium hypochloride was mixed with $1,890 \mathrm{~L}$ (500 gal) of water to yield a chlorine solution that exceeded $1,000 \mathrm{mg} / \mathrm{L}$. The solution was injected using the jetting tool along the entire length of the well filter until all $1,890 \mathrm{~L}$ (500 gal) were injected. The process was repeated for the remaining horizontal well. The chlorine was allowed to remain overnight in the horizontal wells. The following morning, the wells were jetted and overpumped. Excess chlorine removed from the wells was neutralized using a mixing tank with sodium sulfite. Well jetting and overpumping continued for another two days after shock chlorination.

After completion of the well development, pumping tests were performed on both of the horizontal wells and the results were compared with the earlier pump tests conducted prior to the tracer tests. These data were used to assess the effectiveness of the well development program.

\subsection{Development Results}

The video survey conducted prior to development yielded some unexpected results. The horizontal extraction well, which had shown a significant decrease in yield, showed little evidence of clogging. A fine layer of sediment was located on the bottom of the well filter, but there was no evidence of microbial problems or incrustations on the well filter. The appearance of the injection well, however, was very different. A thick layer of gelatinous material coated the well filter on all sides. This material appeared to be organic in nature. The well filter openings were approximately $50 \%$ clogged with this material, yet the injection well showed no pressure increases during operation that would indicate a clogging problem.

Large amounts of sediment were removed during the well development process. Clay particles were the dominant size fraction observed in the discharge water. There was a distinct difference in the sediment type yielded by the two horizontal wells. The horizontal extraction well showed dark grey clayey material typical of the Sunbury shale, while the horizontal injection well showed reddish, clayey material typical of the iron-stained Gallia member. This is consistent with the completion designs of the wells. Although both wells are located along the contact of the Sunbury and Gallia, a large portion of the extraction well filter is completed partially into the Sunbury. The injection well is completed entirely within the Gallia member. 
The jetting tool injected water over 15-cm (6-in) intervals and agitated the surrounding formation with a surging action. This small interval yielded enough sediment to cloud the entire discharge from $70 \mathrm{~m}(230 \mathrm{ft})$ of well filter. This observation suggests that significant quantities of sediment were removed from the wells. However, the amount of sediment did not decrease after three days of jetting, further suggesting that only a portion of the finegrained material surrounding the well filter was removed by the development process.

After shock chlorination and additional development, two series of pumping tests were conducted to evaluate the effectiveness of the development program. The first series of tests consisted of individual 12-h duration pumping tests for each of the horizontal wells. The west horizontal well maintained a flow rate of $43 \mathrm{~L} / \mathrm{min}(11.4 \mathrm{gal} / \mathrm{min})$ and the east horizontal well maintained a flow rate of $34 \mathrm{~L} / \mathrm{min}$ ( $9 \mathrm{gal} / \mathrm{min})$. This compares favorably with the individual pumping tests conducted immediately after the well installation at a rate of $46 \mathrm{~L} / \mathrm{min}(12$ $\mathrm{gal} / \mathrm{min}$ ) for each of the wells (Sect. 5.4). A notable improvement in the efficiency of the west well is also evident because the baseline pumping test conducted just prior to the waterjetting development program indicated that this well could yield $38 \mathrm{~L} / \mathrm{min}(10 \mathrm{gal} / \mathrm{min})$ for a period of only $1 / 2 \mathrm{~h}$ (Sect. 8.1).

After the well development program, a dual-well pumping test was performed for 9 days at a recirculation rate of $57 \mathrm{~L} / \mathrm{min}(15 \mathrm{gal} / \mathrm{min})$ with a maximum drawdown of $1.8 \mathrm{~m}(5.8 \mathrm{ft})$. A hiatus in the field program at the CTS then occurred until September 1996. At this time, the recirculation system was operated continuously for a period of 60 days at a rate of 50 $\mathrm{L} / \mathrm{min}$ (13 gal/min), with no deterioration in the performance of the extraction well. Results of the long-term recirculation test are presented in Fig. 8.1. The pumping rate as a function of time for the post-development test is compared to the declining pumping rate observed during the tracer test and elution test. It was possible to maintain a $50 \mathrm{~L} / \mathrm{min}(13 \mathrm{gal} / \mathrm{min})$ rate after development, while during the tracer test and elution test the pumping rate declined from an initial rate of $76 \mathrm{~L} / \mathrm{min}(20 \mathrm{gal} / \mathrm{min})$ to $23 \mathrm{~L} / \mathrm{min}(6 \mathrm{gal} / \mathrm{min})$ due to well clogging. Figure 8.1 shows that the developed horizontal extraction well maintained a consistent pumping rate with no indication of clogging.

\subsection{Discussion}

Based on the results of the well development program, it appears that fine-grained material in the formation was responsible for clogging the porous well filter and decreasing the well efficiency. Well development using jetting and overpumping significantly increased the efficiency of the horizontal wells.

Development recommendations by the filter manufacturer of low flow pumping until clear water is obtained are not appropriate for fine-grained heterogeneous formations like the Gallia member. Similar to vertical wells, horizontal wells must be mechanically and/or chemically developed to produce and maintain adequate quantities of water. 
Extraction Well

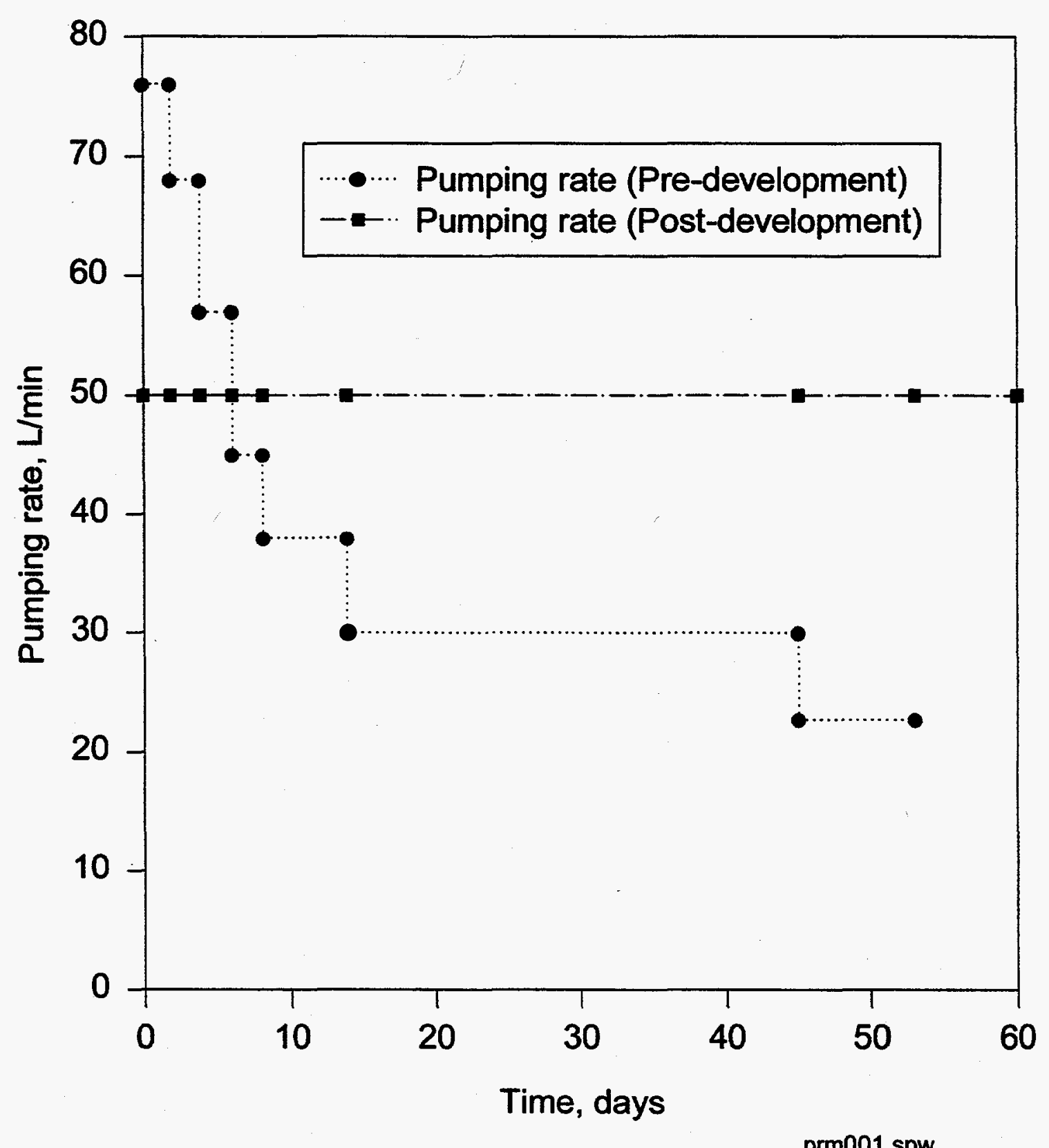

Fig. 8.1. Comparison of the horizontal recirculation rate, pre- and post-development. 
An initial concern of the well development process was that the porous well filter would act as a diffuser thus decreasing agitation of the surrounding formation by the water jets. Based on the development results, it is possible to agitate the surrounding formation. This agitation does appear to be limited considering that the larger particle-size fraction is not removed during the development process.

A preventative program is recommended to reduce the development of bacterial growth in the injection well. Although no increases in injection pressures were observed during operation, it is expected that eventually the bacteria will clog the injection well. It possible to continually inject low concentrations of chlorine directly into the injection well to prevent bacterial growth.

The water-jetting and overpumping development technique generated significant quantities of water. Approximately $18,900 \mathrm{~L}$ (5,000 gal) of water was generated each day during well development. For a contaminated area, onsite treatment may be necessary to handle the large quantity of contaminated development water. 


\section{Conclusions}

This report presents the results of field testing a horizontal well recirculation system at the CTS at PORTS. The recirculation system uses a pair of horizontal wells, one for groundwater extraction and the other for reinjection, to set up a recirculation flow field. The two horizontal wells were installed in October 1994 at a depth of $9 \mathrm{~m}$ (30 ft) using a directional drilling rig. The horizontal sections of the wells are $70 \mathrm{~m}(230 \mathrm{ft})$ long and were placed along the bedrock surface at the base of the Gallia member, a 0.6 to $2 \mathrm{~m} \mathrm{(2} \mathrm{to} 6 \mathrm{ft}$ ) thick zone of moderately permeable, unconsolidated fluvial deposits. The wells were placed with a vertical accuracy of $\pm 15 \mathrm{~cm}$ ( $\pm 0.5 \mathrm{ft}$ ). The horizontal sections were constructed with ductile porous filter, an innovative well material produced in Germany by Schumacher. This was the first installation and testing of this well filter material in the U.S. The well filters have a pore size of $300 \mu \mathrm{m}$ and are composed of cintered spheres of HDPE. Drilling and installation of the wells were completed in six days. A network of piezometers was also installed to assess the hydraulic influence of the horizontal well recirculation system on the surrounding groundwater flow field.

Hydraulic testing results for the horizontal well recirculation system indicate that the Gallia is a heterogenous water-bearing zone. Single-well testing showed hydraulic conductivity values that varied by over two orders of magnitude in the Gallia member and indicated the presence of zones or channels of higher conductivity. Hydraulic tests of the horizontal well recirculation system showed that a hydraulic gradient of 0.15 could be induced between the wells, an increase of two orders of magnitude over the preexisting gradient. Under these conditions, water will travel approximately two orders of magnitude faster than under ambient conditions, with only permeability controlling groundwater flow velocities between the horizontal wells.

A bromide tracer test showed that the entire flow field between the wells was affected by the recirculation system, with bromide transport dominated by advection in higher-permeability areas and by diffusion in lower-permeability areas. A follow-on elution test provided removal of approximately $77 \%$ of the injected bromide mass during a period of 20 days. The tracer test and elution test results indicate that the horizontal well recirculation system shows great promise for application at a contaminated site.

Comparing colloidal borescope velocity measurements with tracer test results provides some interesting relationships. The tracer test showed that bromide reached the extraction well 21 $\mathrm{h}$ after being introduced into the injection well. Using the highest observed hydraulic conductivity for the entire facility of $1.8 \times 10^{-2} \mathrm{~cm} / \mathrm{s}(50 \mathrm{ft} / \mathrm{d})$, an assumed porosity of 0.20 , and neglecting dispersion, it would take 2.6 days for the tracer to reach the extraction well. However, the velocity measured in PZ-06 of $0.037 \mathrm{~cm} / \mathrm{s}(105 \mathrm{ft} / \mathrm{d})$ yields an initial breakthrough resulting from preferential flow zones of approximately $23 \mathrm{~h}$, similar to the time measured by the tracer.

If the velocities of 0.0122 and $0.013 \mathrm{~cm} / \mathrm{s}$ ( 35 and $37 \mathrm{ft} / \mathrm{d}$ ) measured in PZ-19 and PZ-09 represent the average seepage velocity in the area between the recirculation wells under pumping conditions, this would result in a predicted breakthrough time of approximately 2.8 
days. This value is in excellent agreement with the first bromide peak in the horizontal extraction well of approximately 2.6 days.

Clogging of the extraction well filter during the tracer test and elution test resulted in deterioration of well performance. It was determined that the method of well development recommended by the filter manufacturer, low rate pumping, was inadequate. During the fall of 1995 , the horizontal wells were developed by a more aggressive method that included water jetting and overpumping. Hydraulic tests conducted immediately after well development showed markedly improved well performance. During the fall of 1996, a 60day recirculation test was performed with no evidence of clogging. These results indicate that water jetting and overpumping is the proper method for developing wells constructed with the ductile porous filter.

Additional work at PORTS includes field testing of the horizontal well recirculation system at X-701B, a site with TCE and technetium groundwater contamination (ORNL 1995). During this field test, a groundwater treatment system will be linked with the horizontal well recirculation system to test the effectiveness of the recirculation system for groundwater treatment. A description of the treatment system and the results of the pilot test will be presented in a separate report after completion of the test. 


\section{References}

Davis, S. N., D. J. Campbell, H. W. Bentley, and T. J. Flynn. 1985. An Introduction to GroundWater Tracers. EPA/600/2-85/022. U.S. Environmental Protection Agency.

Drever, J. I. 1988. The Geochemistry of Natural Waters. 2nd Ed., Prentice Hall, Englewood Cliffs, New Jersey.

Driscoll, F. G. 1979. Groundwater and Wells. 2nd Ed., Johnson Well Division, ISBN 0-9616456-0-1, St Paul.

Edwards, K. B. 1991. Estimating aquifer parameters from a horizontal well pumping test in an unconfined aquifer. Water Resources Bulletin, 27(5):831-839.

Ferris, J. G. 1950. Quantitative method for determining groundwater characteristics for drainage design. Agricultural Engineering, 31(6):285-291.

Gilman, J. R., and J. R. Jargon. 1992. Evaluating horizontal vs vertical well performance. World Oil, June, pp. 55-60.

Hantush, M. S., and I. S. Papadopulos. 1962. Flow of ground water to collector wells. Journal of Hydraulic Division. Proceedings of the American Society of Civil Engineers, Hy 5:221-244.

Kaback, D. S., B. B. Looney, J. C. Corey, L. M. Wright, and J. L. Steele. 1989. Horizontal wells for in-situ remediation of groundwater and soils. In Proceedings NWWA Outdoor Action Conference, Orlando, pp. 121-135.

Kearl, P. M., J. J. Dexter, and J. E. Price. 1988. Procedures, Analysis, and Compar ison of Groundwater Velocity Measurement Methods for Unconfined Aquifers. UNC/GJ-TMC-3, DOE/ID/12584-10. UNC Geotech, Grand Junction, Colorado.

Kearl, P. M., N. E. Korte, M. Stites, and J. Baker. 1994. Field comparison of micropurging vs. traditional ground water sampling. Ground Water Monitoring and Remediation, Fall, 183-190.

Langseth, D. E. 1990. Hydraulic performance of horizontal wells. In Superfund '90, Proceedings of the 11th National Conference, November, pp. 398-408.

Lohman, S. W. 1979. Ground-Water Hydraulics. Professional Paper 708. U. S. Geological Survey.

Muck, M. T., P. M. Kearl, R. L. Siegrist, N. E. Korte, R. M. Schlosser, M. E. Mumby, D. T. Davenport, D. W. Greene, D. A. Pickering, C. A. Muhr, and J. Strong-Gunderson. 1996. Pilot Test of a Horizontal Well Recirculation System at the Clean Test Site, Portsmouth Gaseous Diffusion Plant. Oak Ridge National Laboratory, Grand Junction, Colorado. 
ORNL. 1994. Work Plan, Quality Assurance Project Plan, Health and Safety Plan for the Installation and Hydrodynamic Testing of a Horizontal Recirculation Treatment System at the Clean Test Site. Oak Ridge National Laboratory, Grand Junction, Colorado.

ORNL. 1995. Final Work Plan and Quality Assurance Project Plan for the Installation and Pilot Testing of a Horizontal Recirculation Treatment System for Treatment of Groundwater at the X-701B Site. Oak Ridge National Laboratory, Grand Junction, Colorado.

PEI. 1992. Horizontal wells inject new life into mature field. Staff report, Petroleum Engineers International, 64(4):49-50.

Renard, G., F. du Petrole, and J. G. Dupuy. 1990. Influence of formation damage on the flow efficiency of horizontal wells. In Society of Petroleum Engineers Symposium, SPE 19414, Lafayette, Louisiana, pp. 133-142.

Speake, R. C., M. Trojan, and Z. Z. Wang. 1992. Modeling the performance of a horizontal groundwater recovery well. In Ground Water Management, Fifth National Outdoor Conference on Aquifer Restoration, Ground Water Monitoring, and Geophysical Methods, 399-415. Dublin, Ohio.

Suzuki, K., and T. Nanba. 1990. Horizontal well test analysis system. In Society of Petroleum Engineers 65th Annual Conference, pp 893-904, New Orleans, Louisiana.

U.S.EPA. 1989a. Ground Water Issue: Performance and Evaluations of Pump-andTreat Remediations. EPA/540/4-89/005. U. S. Environmental Protection Agency.

U.S.EPA. 1989b. Technology Evaluation Report: SITE Program Demonstration Test, Terra Vac In Situ Vacuum Extraction System, Groveland, Massachusetts. EPA/540/589/003a. U. S. Environment Protection Agency. 
Appendix A

Geologic Logs and Geotechnical Data for Boreholes at the Clean Test Site 
OAK RIOGE NATIONAL LABORATORY

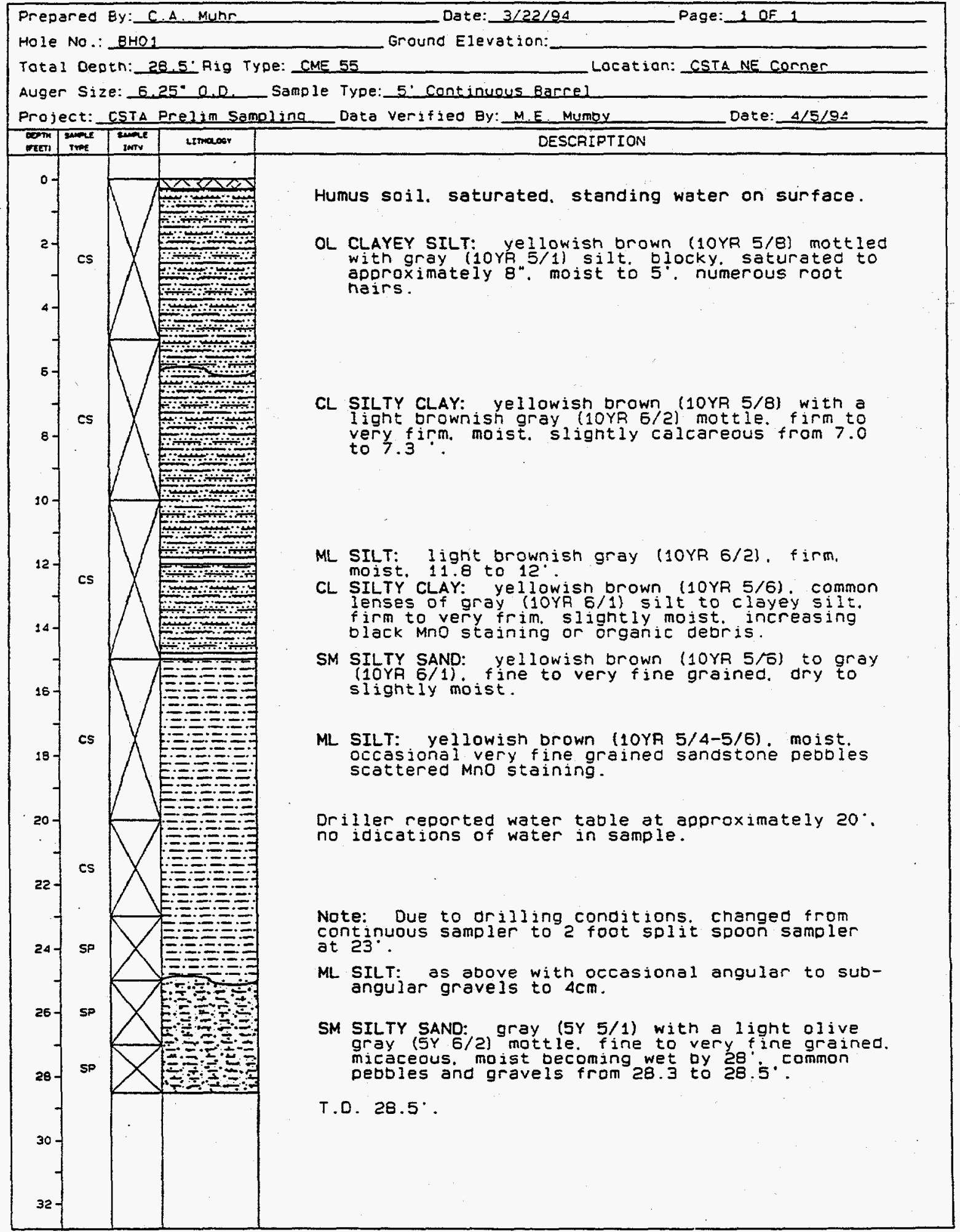


DTI 1 OAK RIDGE NATIONAL LABORATOAY

Borehole Summary Information

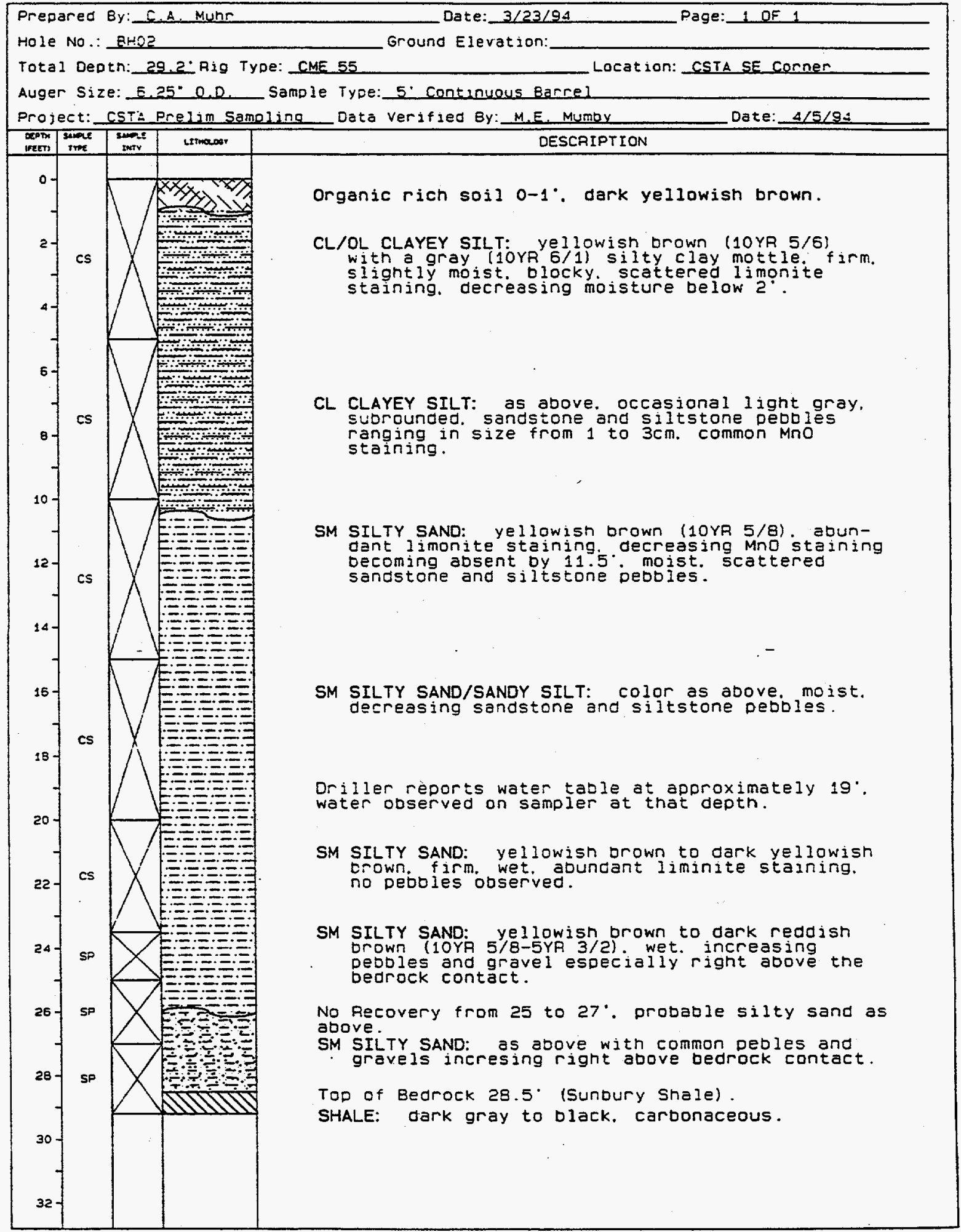


DIn 1 oak rioge national Laboratory

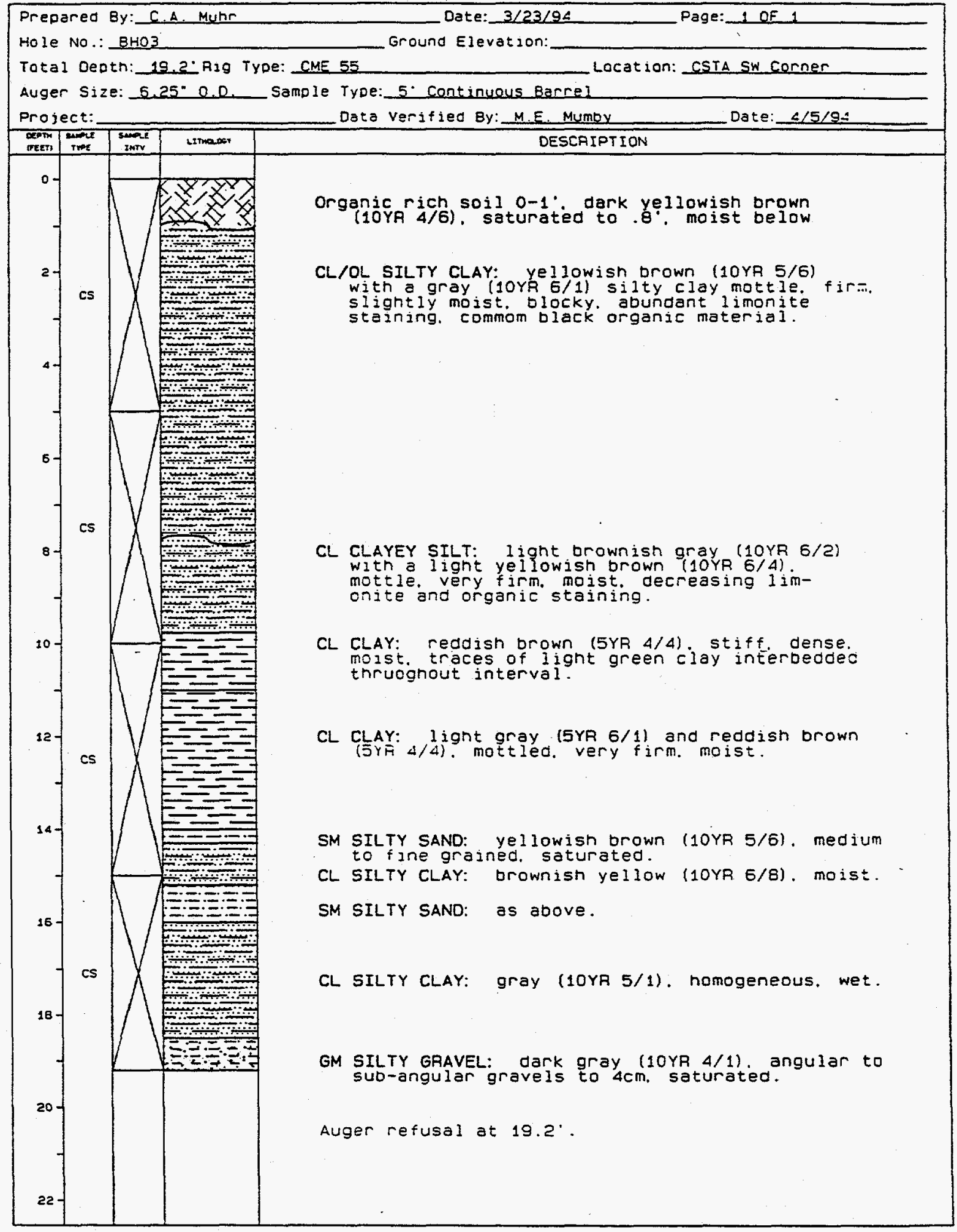




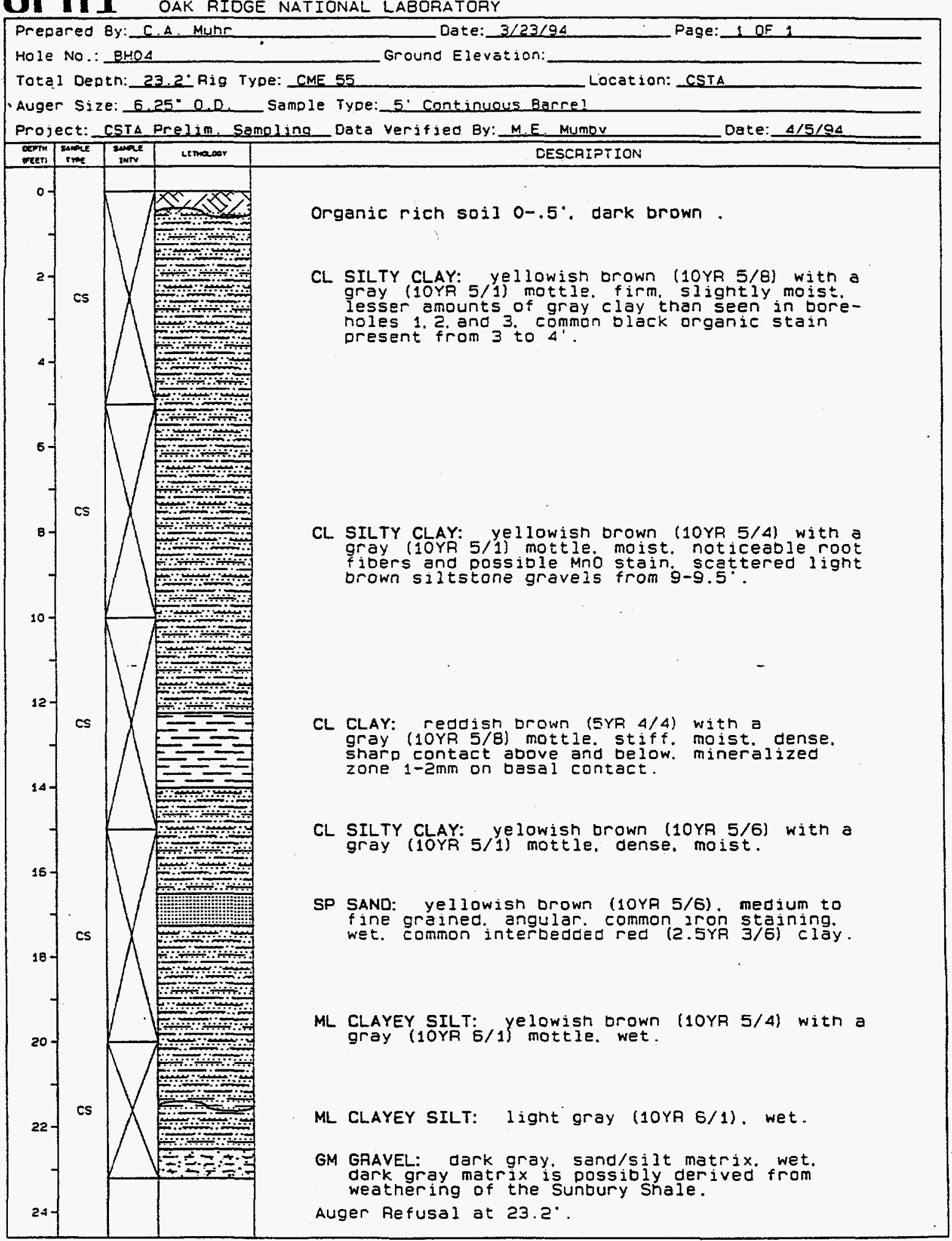


ornl

Borehole Summary Information

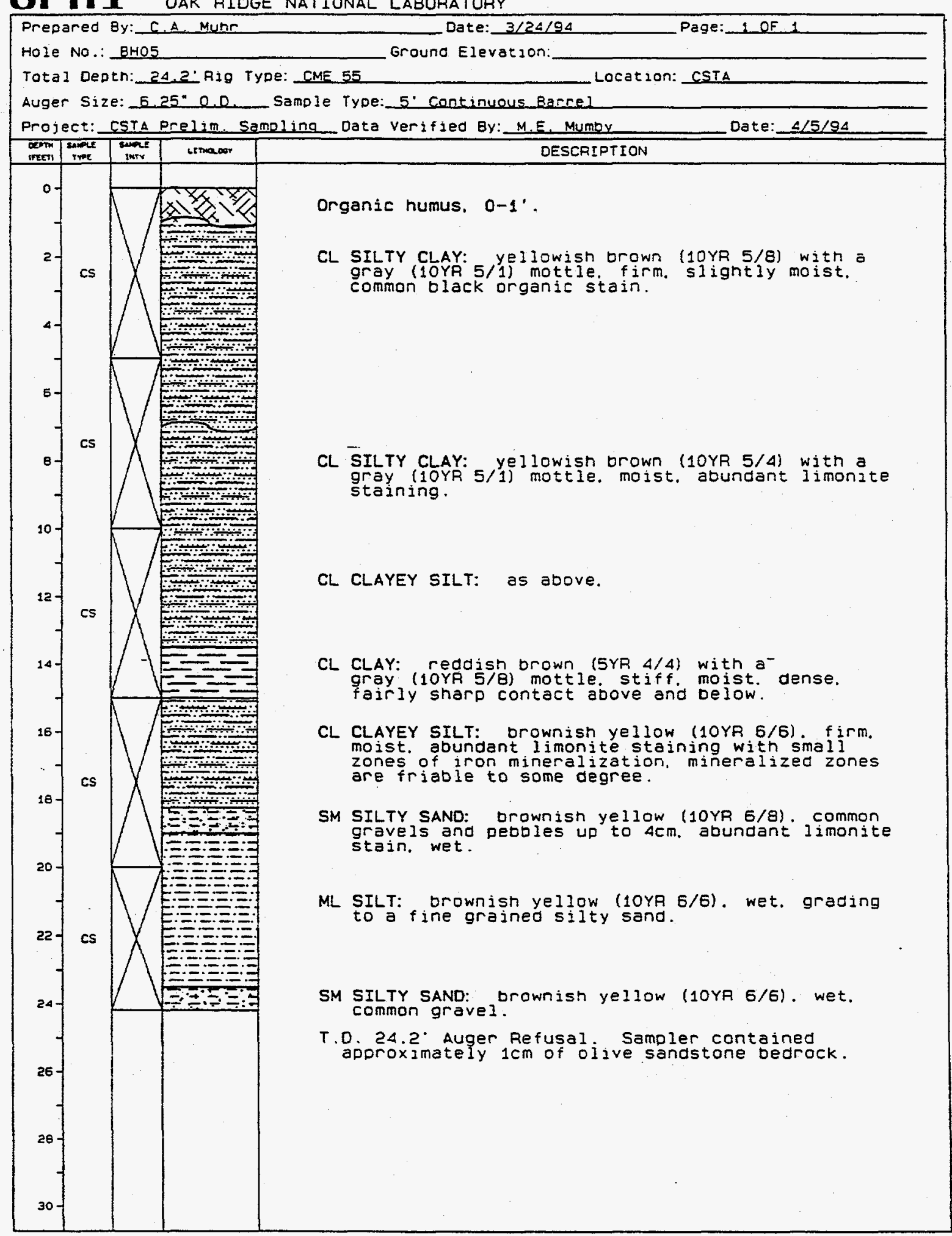


QIn 1 oak RIDGE national Laboratary

\section{Borehole Summary Information}

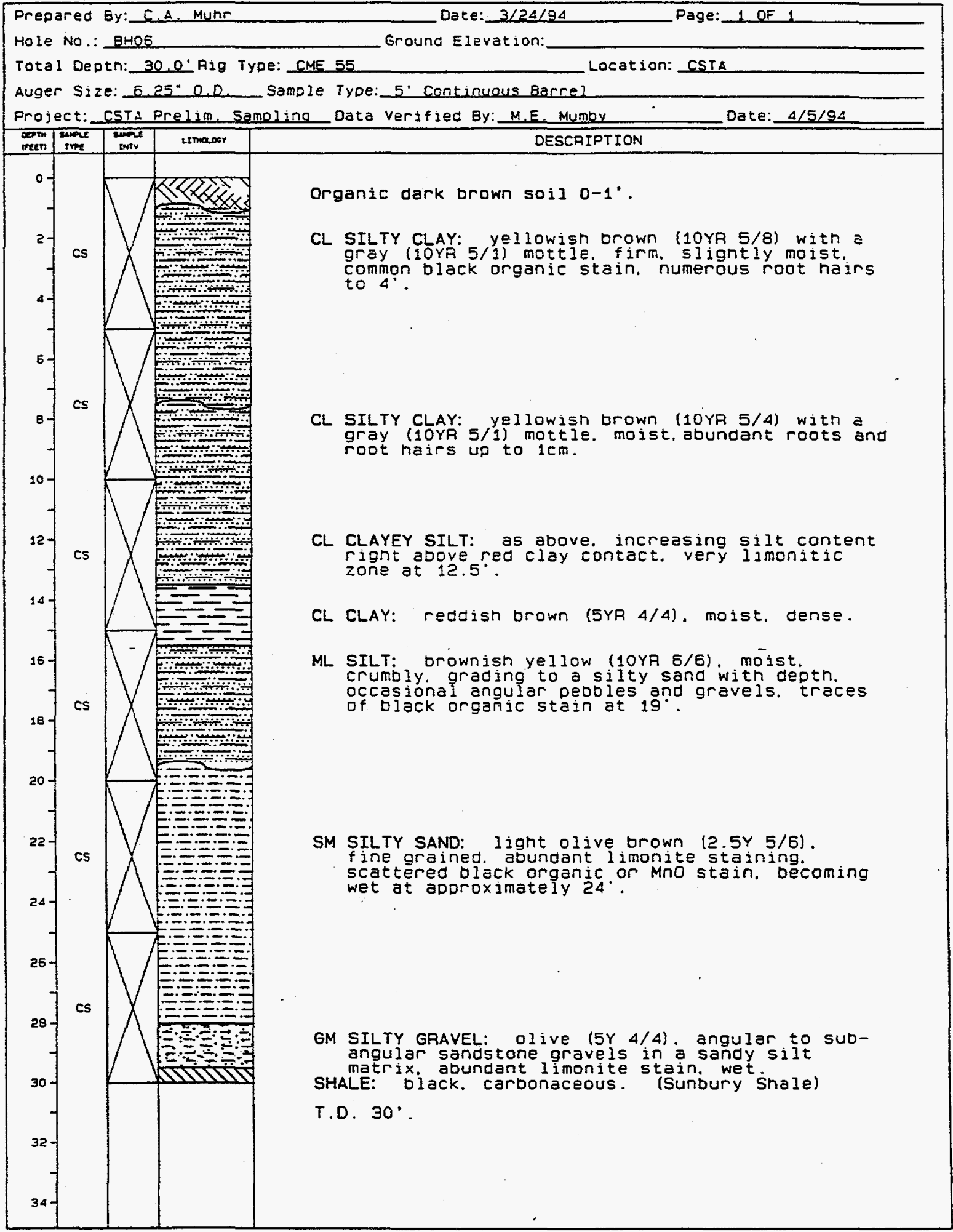


orn 1

Borenole Summary Information

OAK RIDGE NATIONAL LABORATORY

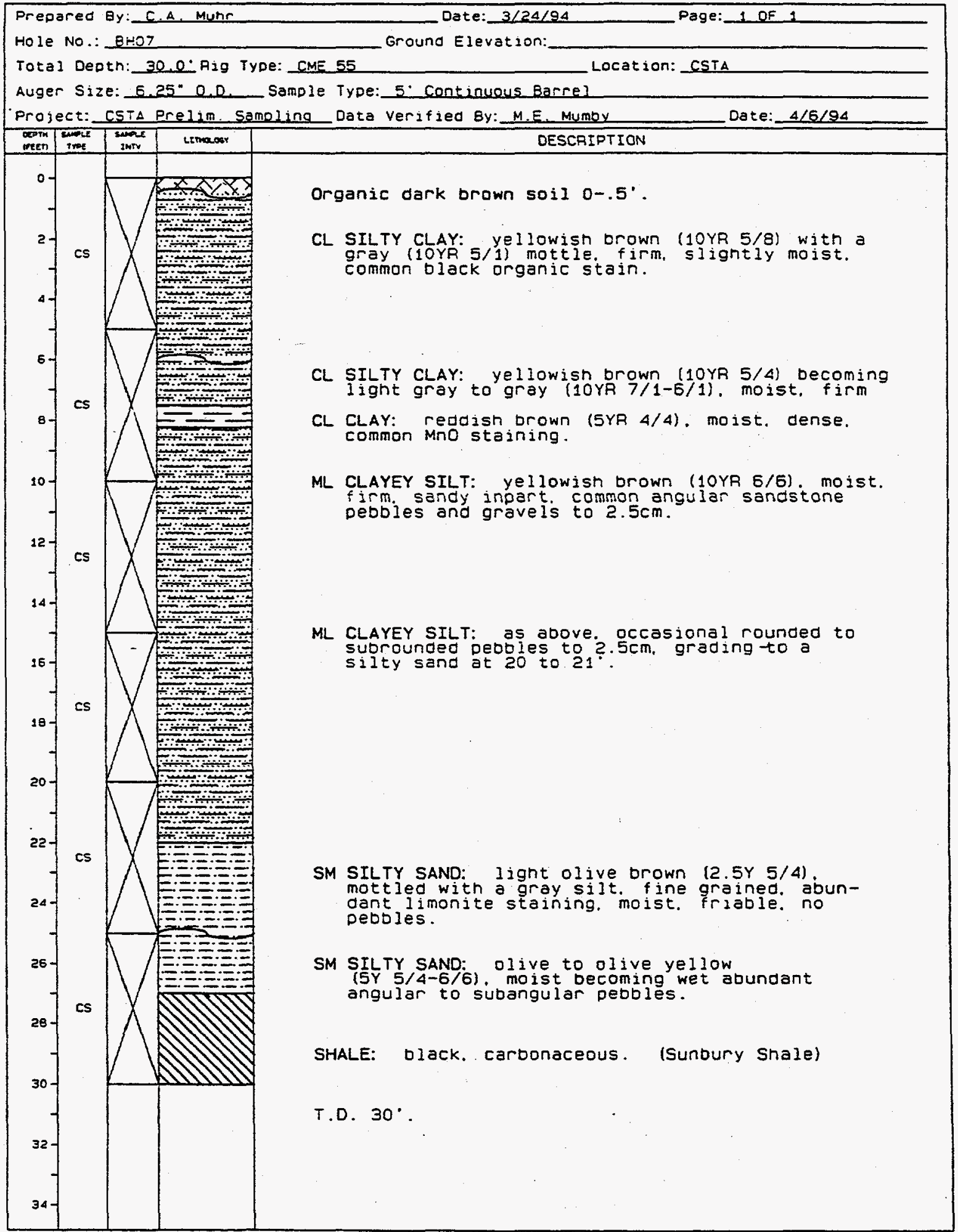


OrI 1 oak ridge national Laboratory

\section{Borehole Summary Information}

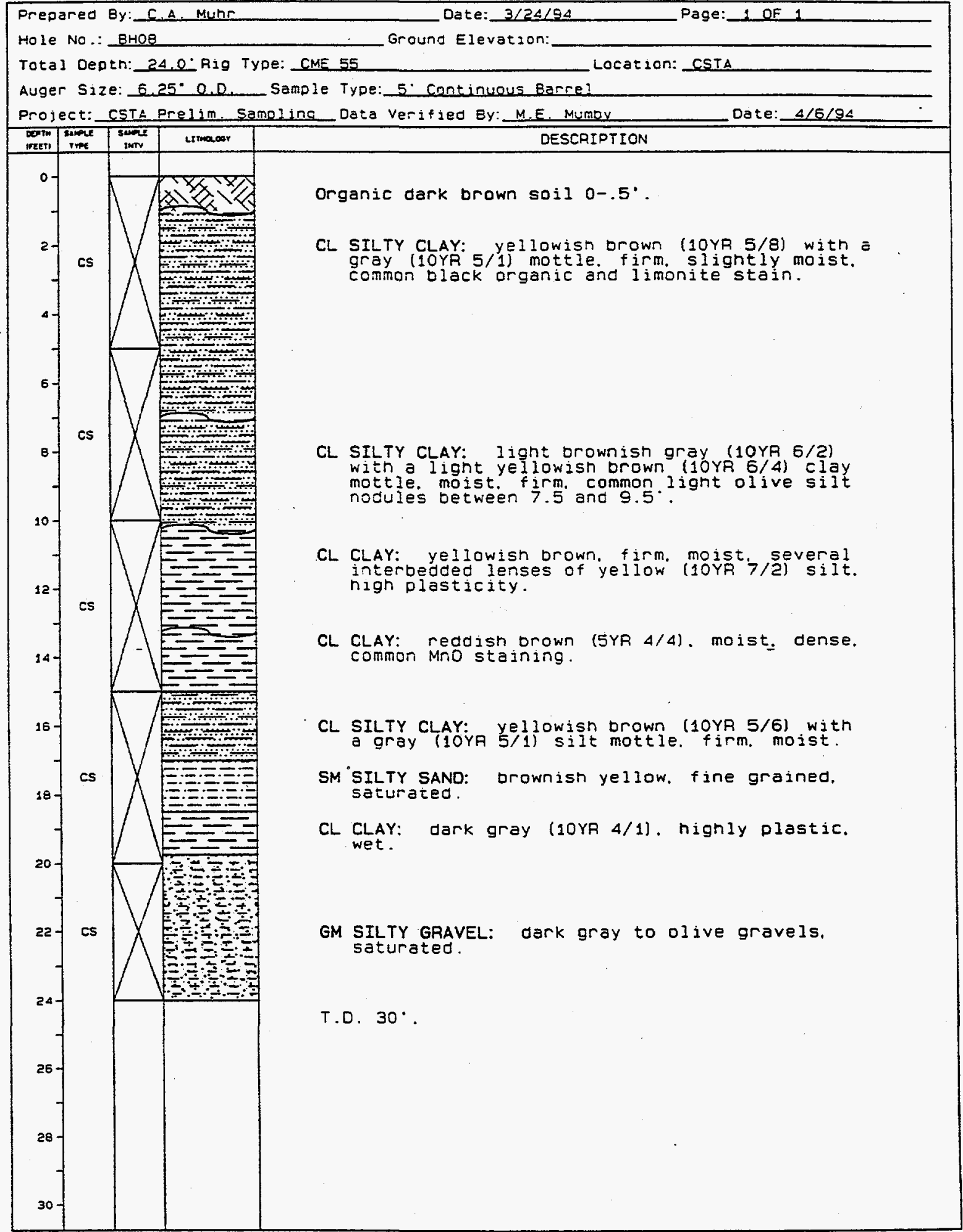


orn 1

Borehole Summary Information

OAK RIDGE NATIONAL LABORATORY

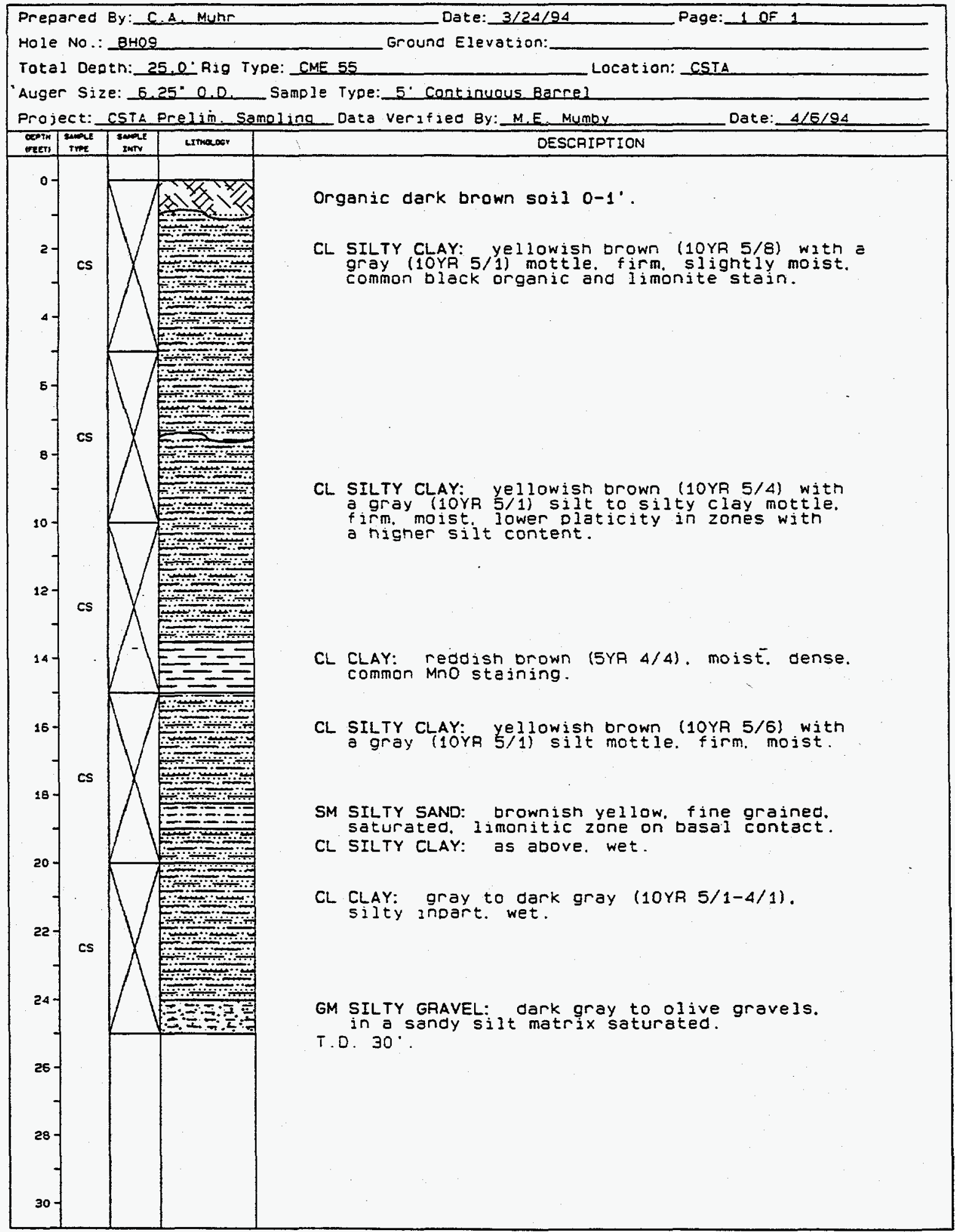




\section{SUMMARY OF LABO、 . IORY TEST RESULTS}

\begin{tabular}{|c|c|c|c|c|c|c|c|c|c|c|c|c|}
\hline & & & & & $\begin{array}{r}\text { WE } \\
(P\end{array}$ & & $\begin{array}{l}\text { SPECIFIC } \\
\text { GRAVITY }\end{array}$ & ATT & $\begin{array}{l}\text { IBEAG } \\
\text { ITS }\end{array}$ & & & $\begin{array}{l}\text { Project: Portamouth ODT Min/ Characterization } \\
\text { Project Number: } 0-4267-0088\end{array}$ \\
\hline $\begin{array}{l}\text { Hole } \\
\text { No. }\end{array}$ & $\begin{array}{l}\text { Sample } \\
\text { No. }\end{array}$ & $\begin{array}{l}\text { Sample } \\
\text { Type* }\end{array}$ & $\begin{array}{l}\text { Depth } \\
\text { (fi) }\end{array}$ & $\begin{array}{l}\text { Natural } \\
\text { Molsture } \\
\text { (\%) }\end{array}$ & Wot & Dry & G, & $\begin{array}{l}\text { Liquid } \\
\text { Limit } \\
(\%)\end{array}$ & $\begin{array}{l}\text { Plasticity } \\
\text { Index } \\
(\%)\end{array}$ & $\begin{array}{l}\text { Unified } \\
\text { Soll } \\
\text { Classification }\end{array}$ & $\begin{array}{l}\text { Other } \\
\text { Test } \\
t \leftarrow\end{array}$ & Soll Description \\
\hline $\mathrm{BH}-1-05$ & & ss & 5.0 & 23.4 & & & 2.66 & 49 & 31 & $\mathrm{CL}$ & & $\begin{array}{l}\text { CLAY, silty. Ilght yellowish brown mottled gray } \\
\text { whth roots }\end{array}$ \\
\hline $\mathrm{BH}-1 \cdot 13.5$ & & SS & $13.0 \cdot 13.5$ & 32.4 & & & 2.63 & 64 & 38 & $\mathrm{CH}$ & & CLAY, silty, reddish-brown mottled black \\
\hline BH-1.22 & & ss & $21.5 \cdot 22.0$ & 21.2 & & & 2.67 & 27 & 15 & CL & & $\begin{array}{l}\text { CLAY, silty, light yellowish brown mottled brown } \\
\text { with weathered shale fragments }\end{array}$ \\
\hline $\mathrm{BH}-2.05$ & & ss & $4.5 \cdot 5.0$ & 22.6 & & & 2.60 & 33 & 14 & $\mathrm{CL}$ & & $\begin{array}{l}\text { CLAY, sllty, light yollowish brown mottled gray } \\
\text { and brown with rock fragments }\end{array}$ \\
\hline BH-2-14 & & ss & $13.5 \cdot 14.0$ & 22.6 & & & 2.69 & 26 & 12 & CL & & CLAY, silty, sllghtly sandy, tan \\
\hline $\mathrm{BH}-2-28$ & & Ss & $27.5 \cdot 28.0$ & 19.1 & & & 2.75 & 31 & 13 & CL & & $\begin{array}{l}\text { CLAY, sllty, dark yellowish brown whth rock } \\
\text { fragments }\end{array}$ \\
\hline$B H-3-\infty$ & & Ss & $8.5 \cdot 9.0$ & 24.5 & & & 2.66 & 50 & 28 & $\mathrm{CL}$ & & CLAY, sllty, tan mottled light gray \\
\hline BH-3-12 & & ss & $11.5 \cdot 12.0$ & 35.5 & & & 2.73 & 72 & 49 & $\mathrm{CH}$ & & CLAY, sllty, light brown mottled gray \\
\hline BH-3-19 & & ss & $18.5 \cdot 19.0$ & 17.7 & & & 2.68 & 23 & 11 & CL. & & $\begin{array}{l}\text { CLAY, sllty, dark greenish brown with rock } \\
\text { tragments }\end{array}$ \\
\hline $8 \mathrm{H}-4-07$ & & ss & $6.5 \cdot 7.0$ & 26.7 & & & 2.69 & 60 & 35 & $\mathrm{CH}$ & & $\begin{array}{l}\text { CLAY, sllty, light brown mottled gray and } \\
\text { yellowish-brown }\end{array}$ \\
\hline $\mathrm{BH} \cdot 4 \cdot 15$ & & Ss & $14.5 \cdot 15.0$ & 31.0 & & & 2.69 & 69 & 43 & $\mathrm{CH}$ & & CLAY, silty, light brown mottled gray \\
\hline
\end{tabular}

- STSHELBY TUBE SAMPLE, SS.SPLIT SPOON SAMPLE, B-BAg SAMPLE "TEST AESULTS REPOATED ON OTHER SHEETS:

C-CONSOLIDATION

P.PROCTOR TEST

S-SIEVE OR GRAIN SIZE ANALYSIS

U.UNCONFINED COMPRESSION TEST

D-DIRECT SHEAR TEST

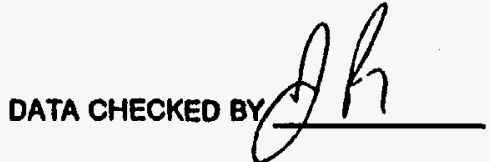

GA Technical Services 


\section{SUMMARY OF LABO، .. .TORY TEST RESULTS}

\begin{tabular}{|c|c|c|c|c|c|c|c|c|c|c|c|c|}
\hline & & & & & & & $\begin{array}{l}\text { SPECIFIC } \\
\text { GRAVITY }\end{array}$ & ATT & $\begin{array}{l}\text { BERG } \\
\text { ITS }\end{array}$ & & & $\begin{array}{l}\text { Project: Portemouth ODT Minl Charectorketion } \\
\text { Project Number: } 04267-0088\end{array}$ \\
\hline $\begin{array}{l}\text { Hole } \\
\text { No. }\end{array}$ & $\begin{array}{l}\text { Sample } \\
\text { No. }\end{array}$ & $\begin{array}{l}\text { Sample } \\
\text { Type* }\end{array}$ & $\begin{array}{c}\text { Depth } \\
\text { (it) }\end{array}$ & $\begin{array}{l}\text { Netural } \\
\text { Molsture } \\
(\%)\end{array}$ & Wot & Dry & G. & $\begin{array}{l}\text { Liquild } \\
\text { Limit } \\
(\%)\end{array}$ & $\begin{array}{l}\text { Plastletty } \\
\text { Index } \\
(\%) \\
\end{array}$ & $\begin{array}{c}\text { Unifled } \\
\text { Soll } \\
\text { Classilicedition } \\
\end{array}$ & $\begin{array}{c}\text { Other } \\
\text { Teot } \\
\text { N"* }\end{array}$ & Soll Description \\
\hline BH-4-21 & & ss & $20.5 \cdot 21.0$ & 36.7 & & & 2.72 & 48 & 26 & CL & & $\begin{array}{l}\text { CLAY, sllty, brown mottled gray and reddish- } \\
\text { brown }\end{array}$ \\
\hline BH.5.08 & & ss & $7.5 \cdot 8.0$ & 32.3 & & & 2.69 & 6 & 44 & $\mathrm{CH}$ & & CLAY, silty, llght brown mottled gray \\
\hline BH.5.13 & & ss & $12.5 \cdot 13.0$ & 39.9 & & & 2.70 & 46 & 26 & I CL & & $\begin{array}{l}\text { CLAY, silty, llght brown mottled gray yollowish- } \\
\text { brown and reddish-brown }\end{array}$ \\
\hline BH-5.19 & & ss & $18.5 \cdot 19.0$ & 20.7 & & & 2.66 & 28 & 11 & CL. & & $\begin{array}{l}\text { CLAY, silty, yellowish brown mottled light gray } \\
\text { whth rock tragments }\end{array}$ \\
\hline BH.5.23 & & ss & $22.5-23.0$ & 30.9 & & & 2.70 & 28 & 15 & CL & & CLAY, sllty slightly sandy ligit yellowtsh-brown \\
\hline BH-6-02 & & ss & $1.5 \cdot 2.0$ & 25.9 & & & 2.62 & 41 & 25 & CL & & CLAY, silty, llght yellowlsh-brown \\
\hline BH-6-18 & & ss & $17.5-18.0$ & 21.7 & & & 2.65 & 26 & 13 & CL. & & CLAY, silty, llght yellowlsh-brown \\
\hline BH-6-29 & & ss & $28.5 \cdot 29.0$ & 14.3 & & & 2.69 & & & & & CLAY, sllty, dark brown with rock tregments \\
\hline $\mathrm{BH}-7-12$ & & ss & $11.5 \cdot 12.0$ & 20.7 & & & 2.70 & 28 & 14 & CL & & CLAY, silty, slightly sandy, light yollowtsh-brown \\
\hline BH.7.20 & & ss & $19.5 \cdot 20.0$ & 10.3 & & & 2.65 & 30 & 14 & CL & & CLAY, sllty, slightly sandy, yellowlsh-brown \\
\hline $\mathrm{BH}-7.26$ & & ss & $25.5 \cdot 26.0$ & 17.3 & & & 2.65 & 29 & 12 & CL & & CLAY, silty, dar brown \\
\hline
\end{tabular}

- ST-SHELBY TUBE SAMPLE, SS.SPLIT SPOON SAMPLE, B-BAg SAMPLE * TEST RESULTS REPORTED ON OTHER SHEETS:

C.CONSOLIDATION

S-SIEVE OR GRAIN SIZE ANALYSIS

U.UNCONFINED COMPRESSION TEST
P.PROCTOR TEST

D-DIRECT SHEAA TEST T-TRIAXIAL TEST

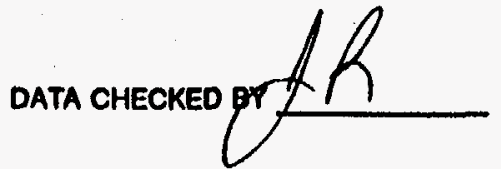

GA Technical Services 


\section{SUMMARY OF LABO IORY TEST RESULTS}

\begin{tabular}{|c|c|c|c|c|c|c|c|c|c|c|c|c|}
\hline & & & & & $\begin{array}{r}\text { WE } \\
\mathbf{P}\end{array}$ & & $\begin{array}{l}\text { SPECIFIC } \\
\text { GRAVITY }\end{array}$ & ATT & $\begin{array}{l}\text { IBERG } \\
\text { ITS }\end{array}$ & & & $\begin{array}{l}\text { Project: Portsmouth ODT Mini Charecterization } \\
\text { Project Number: } \underline{0-4267-0088}\end{array}$ \\
\hline $\begin{array}{l}\text { Hole } \\
\text { No. }\end{array}$ & $\begin{array}{l}\text { Sample } \\
\text { No. }\end{array}$ & $\begin{array}{l}\text { Sample } \\
\text { Type* }\end{array}$ & $\begin{array}{l}\text { Depth } \\
\text { (fi) }\end{array}$ & $\begin{array}{c}\text { Netural } \\
\text { Molsture } \\
(\%)\end{array}$ & Wet & Dry & G, & $\begin{array}{l}\text { Liquid } \\
\text { Limit } \\
(\%)\end{array}$ & $\begin{array}{l}\text { Plasticity } \\
\text { Index } \\
(\%)\end{array}$ & $\begin{array}{l}\text { Unifled } \\
\text { Soll } \\
\text { Clessification }\end{array}$ & $\begin{array}{c}\text { Other } \\
\text { Test } \\
\text { n }\end{array}$ & Soll Description \\
\hline $\mathrm{BH}-8-13$ & & ss & $12.5 \cdot 13.0$ & 33.5 & & & 2.68 & 61 & 41 & $\mathbf{C H}$ & & CLAY, silty, reddish-brown \\
\hline $8 \mathrm{H}-6.22$ & & ss & $21.5 \cdot 22.0$ & 28.5 & & & 2.72 & 26 & 12 & $\mathrm{CL}$ & & $\begin{array}{l}\text { CLAY, silty, dark brown mottled dark gray wilh } \\
\text { rock fragments }\end{array}$ \\
\hline BH-9-09 & & SS & $8.5 \cdot 9.0$ & 33.6 & & & 2.70 & 71 & 48 & $\mathrm{CH}$ & & $\begin{array}{l}\text { CLAY, silty, light reddish-brown mottled gray and } \\
\text { yellowish-brown }\end{array}$ \\
\hline BH-9-21 & & ss & $20.9 \cdot 21.0$ & 36.4 . & & & 2.73 & 53 & 28 & $\mathrm{CH}$ & & CLAY, sllty, gray mottled reddish-brown \\
\hline BH-9-21.5 & & ss & $21.0 \cdot 21.5$ & 29.9 & & & 2.75 & 51 & 26 & $\mathrm{CH}$ & & CLAY, slity, gray mottled greenish-brown \\
\hline & & & & & & & & & & & & \\
\hline & & & & & & & & & & & & \\
\hline & & & & & & & & & & & & \\
\hline & & & & & & & & & & & & \\
\hline & & & & · & & & & & & & & \\
\hline & & & & & & & & & & & & \\
\hline
\end{tabular}

"ST-SHELBY TUBE SAMPLE, SS-SPLIT SPOON SAMPLE, B-BAG SAMPLE "TEST RESULTS REPORTED ON OTHER SHEETS:

C-CONSOLIOATION

S-SIEVE OR GRAIN SIZE ANALYYSIS

U-UNCONFINED COMPAESSION TEST
P.PROCTOR TEST

D.DIRECT SHEAR TEST

T.TAIAXIAL TEST

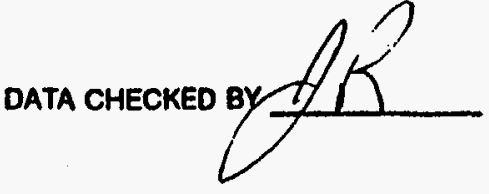




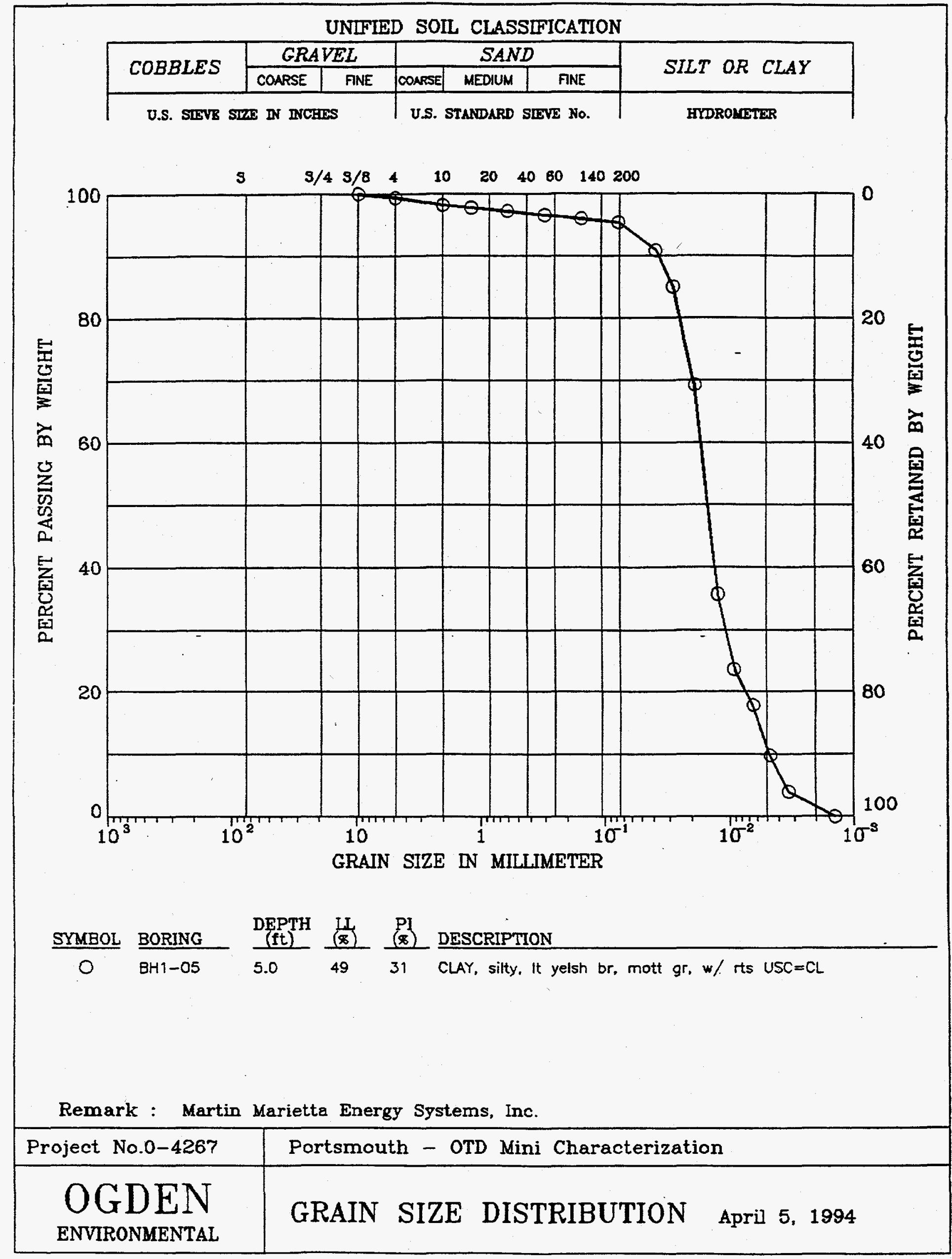




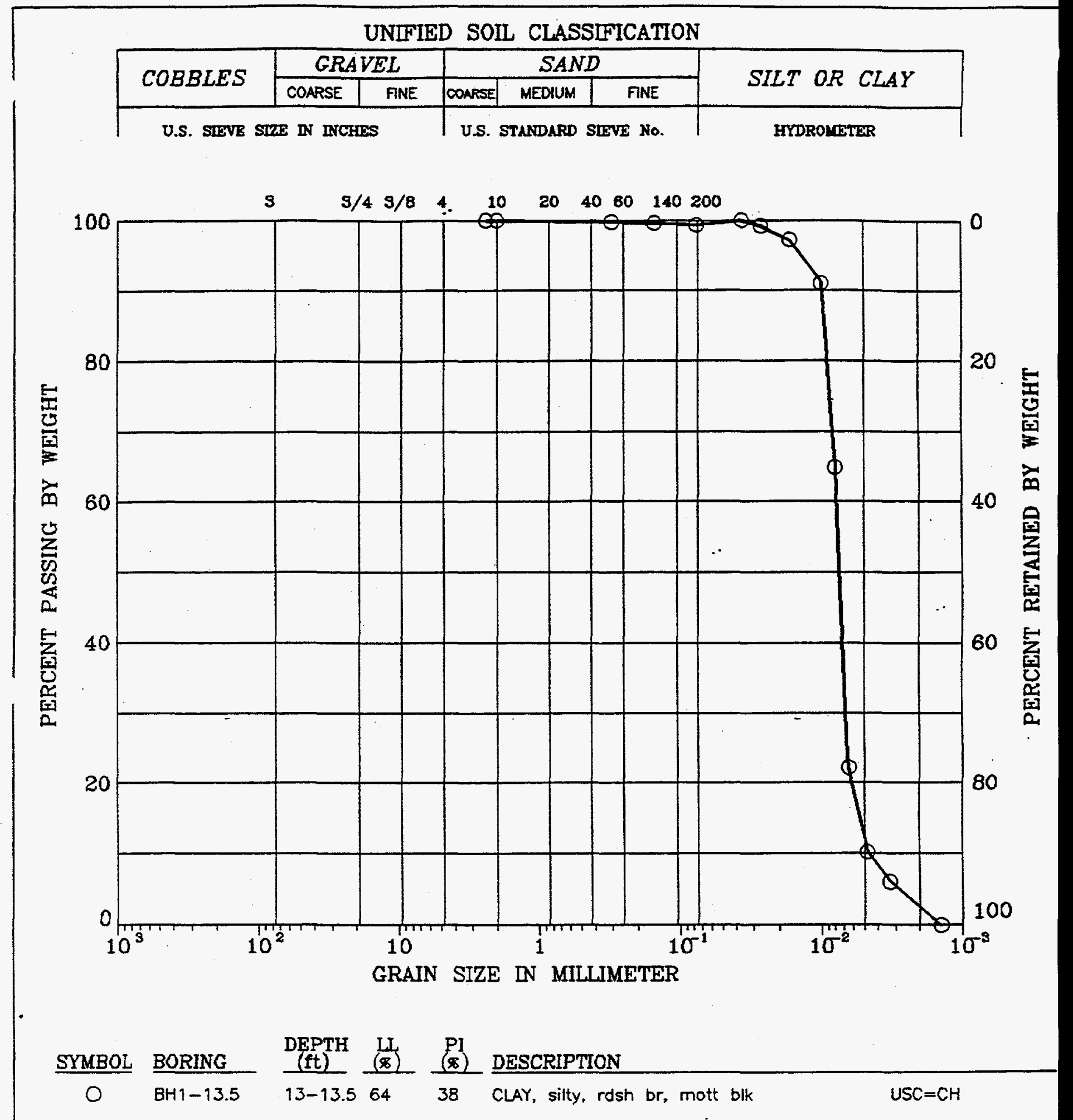

Remark : Martin Marietta Energy Systems, Inc.

\begin{tabular}{|c|l|}
\hline Project No.0-4267 & Portsmouth - OTD Mini Characterization \\
\hline $\begin{array}{c}\text { OGDENN } \\
\text { ENVIRONMENTAL }\end{array}$ & GRAIN SIZE DISTRIBUTION April 5, 1994 \\
\hline
\end{tabular}




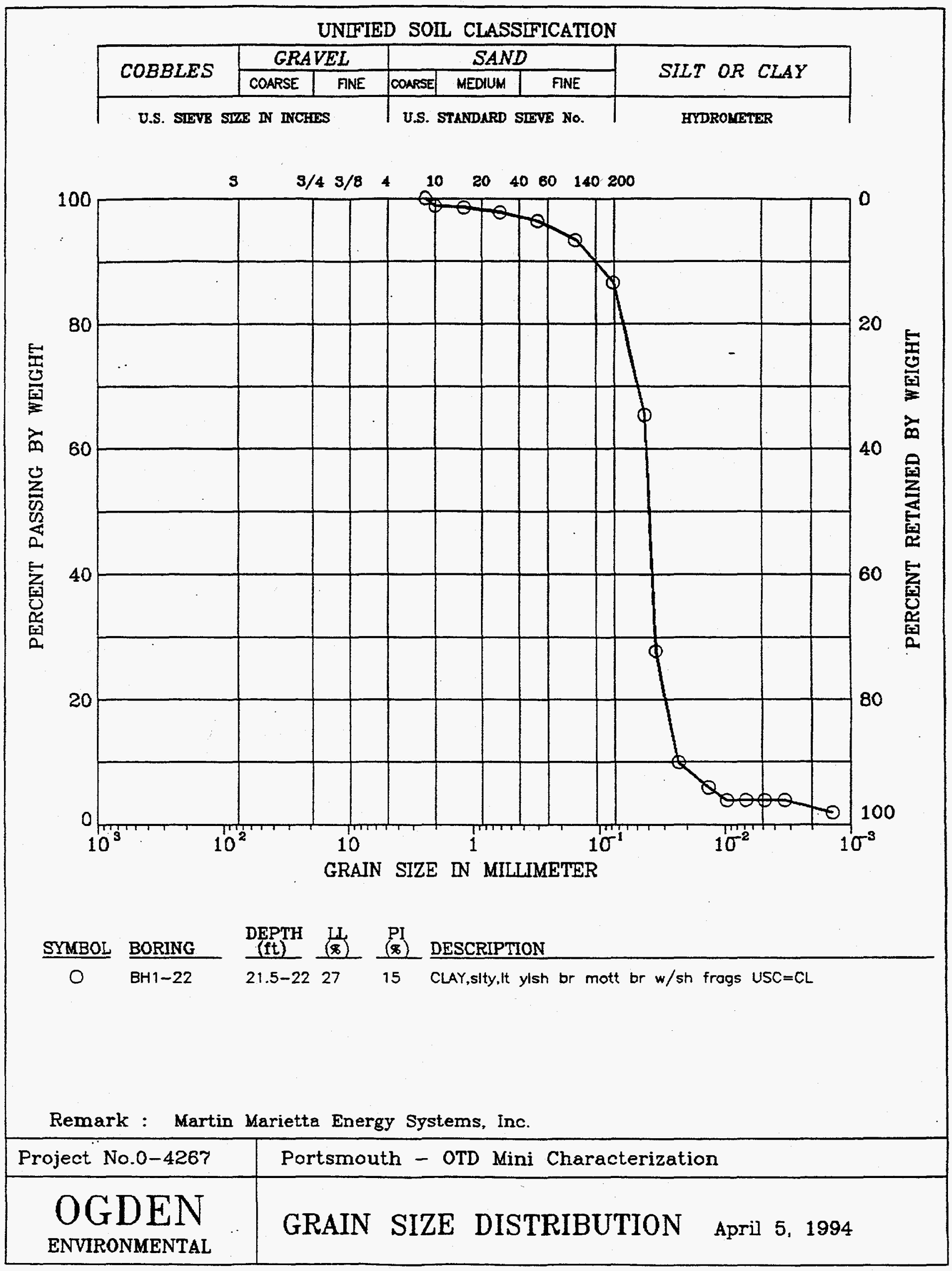




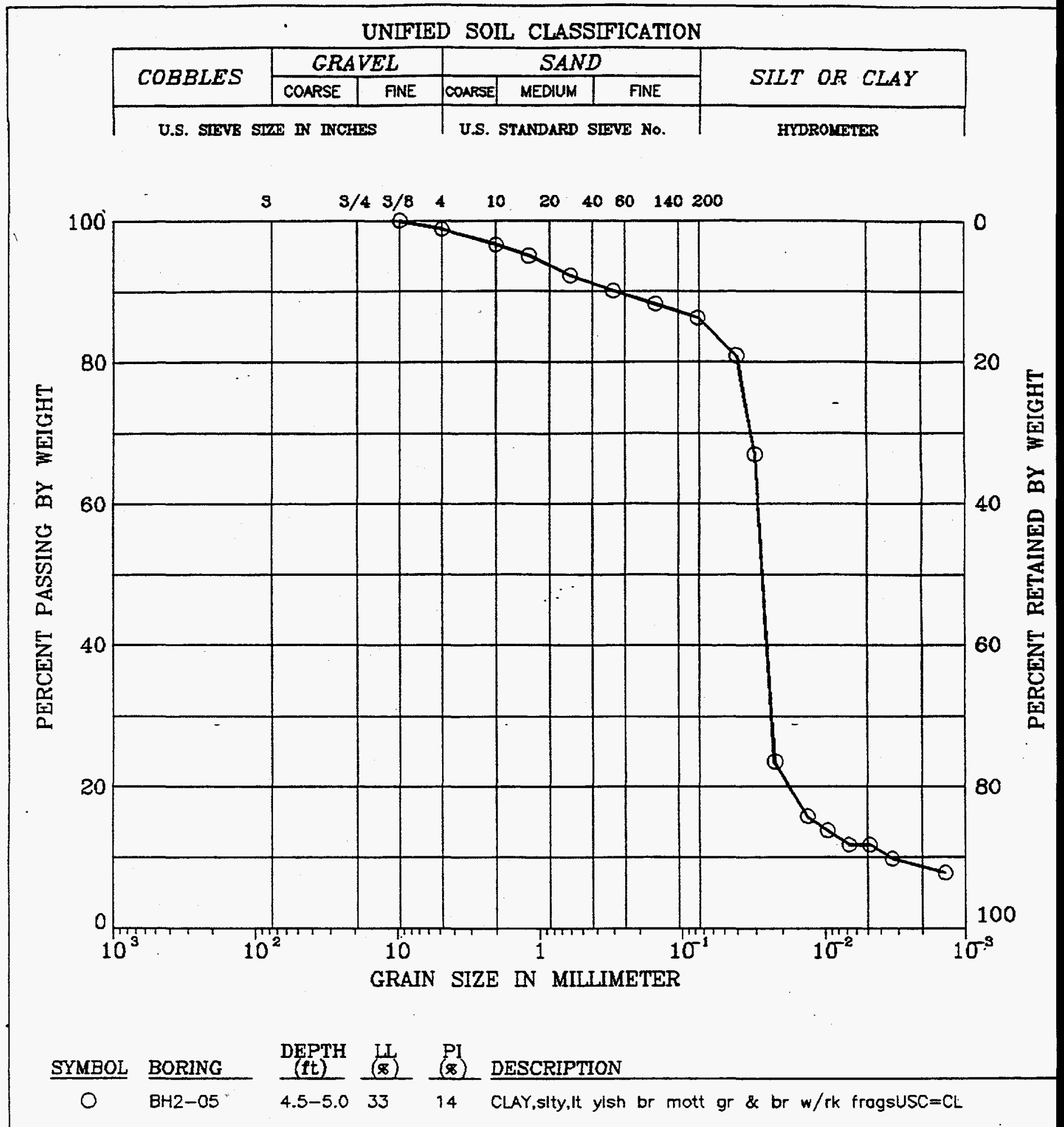

Remark : Martin Marietta Energy Systems, Inc.

\begin{tabular}{|c|l}
\hline Project No.0-4267 & Portsmouth - OTD Mini Characterization \\
\hline $\begin{array}{c}\text { OGDEN } \\
\text { ENVIRONMENTAL }\end{array}$ & GRAIN SIZE DISTRIBUTION April 5, 1994
\end{tabular}




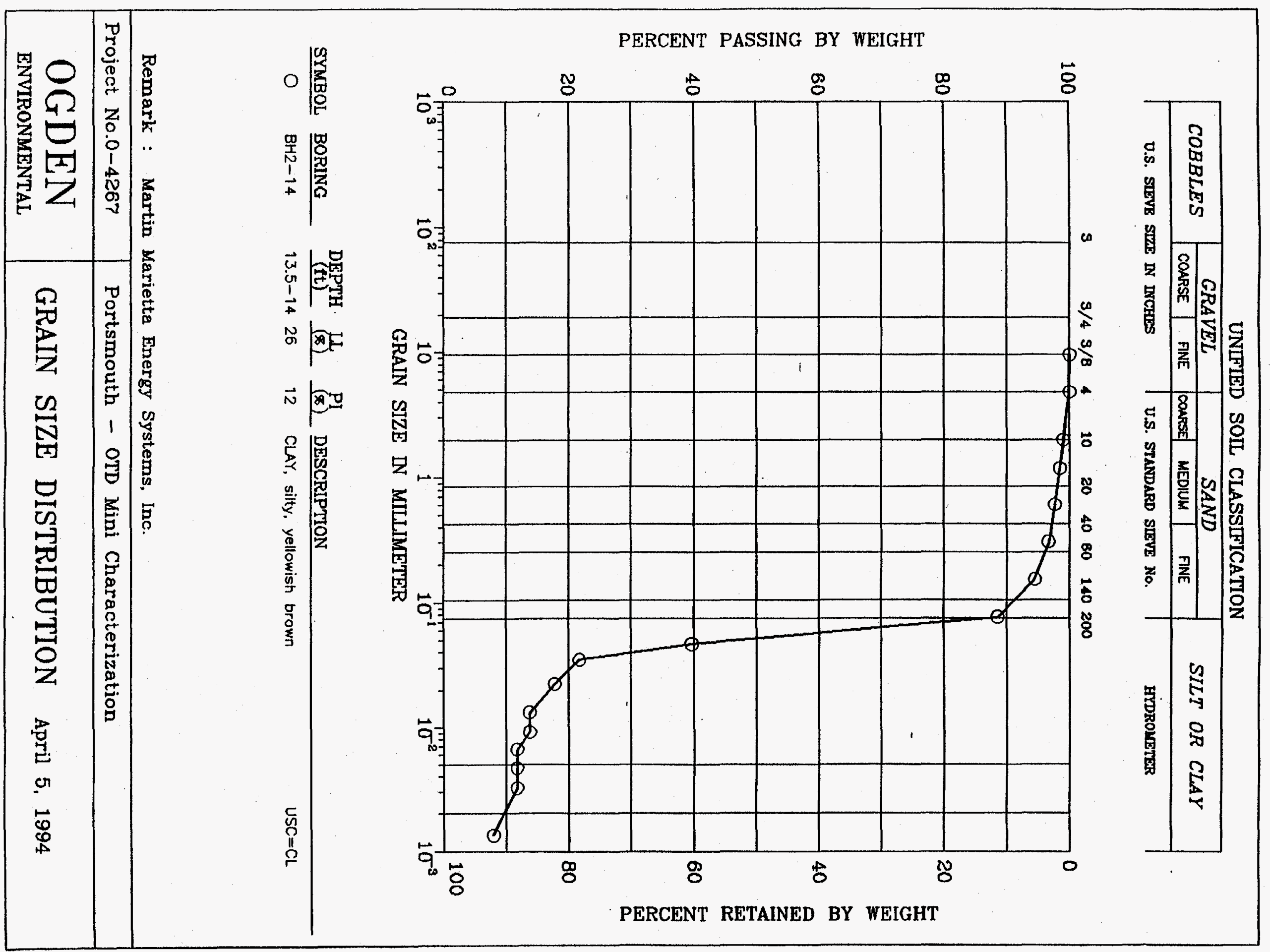




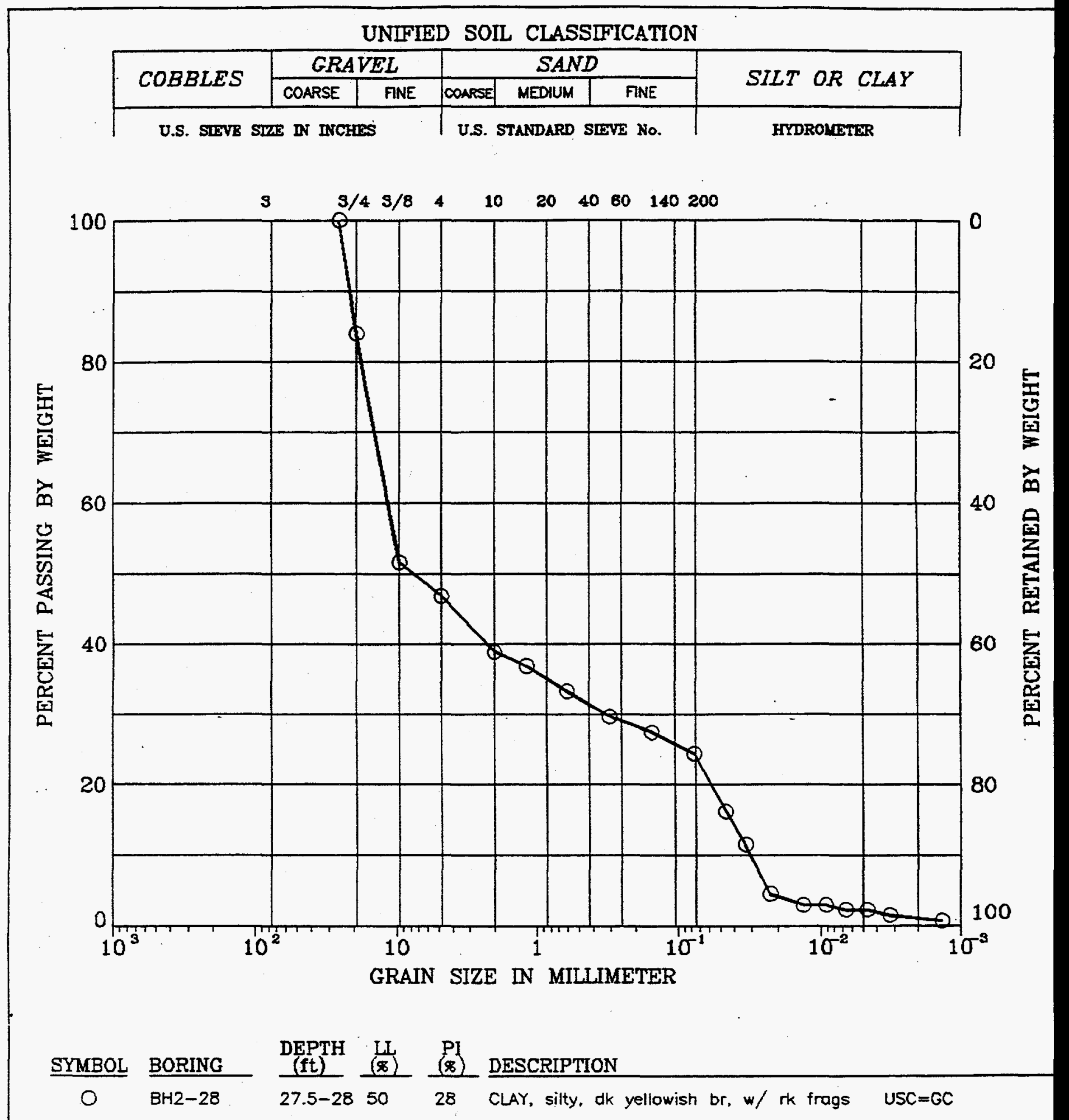

Remark : Martin Marietta Energy Systems, Inc.

\begin{tabular}{c|l}
\hline Project No.0-4267 & Portsmouth - OTD Mini Characterization \\
\hline OGDEN & GRAIN SIZE DISTRIBUTION April 5. 1994
\end{tabular}




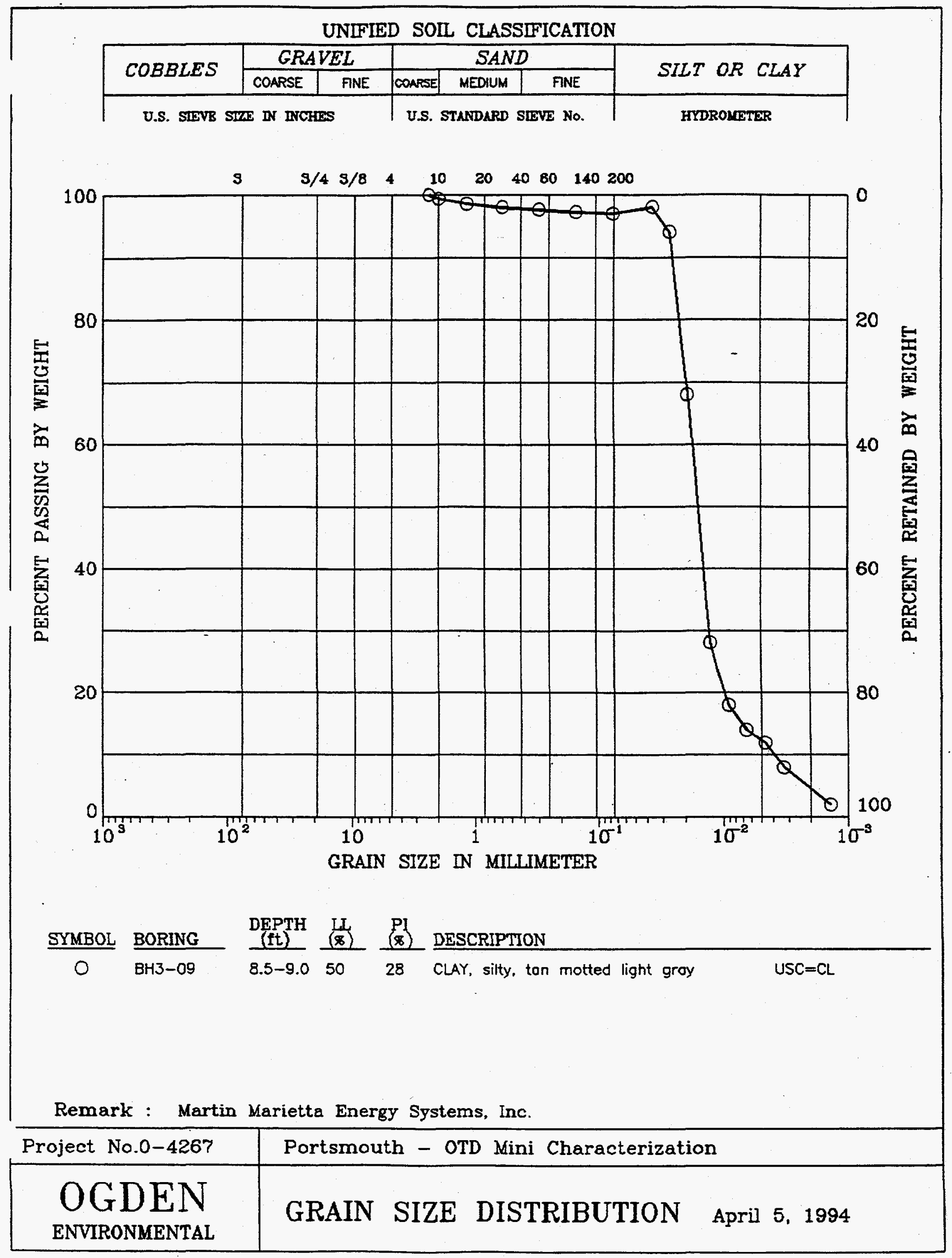




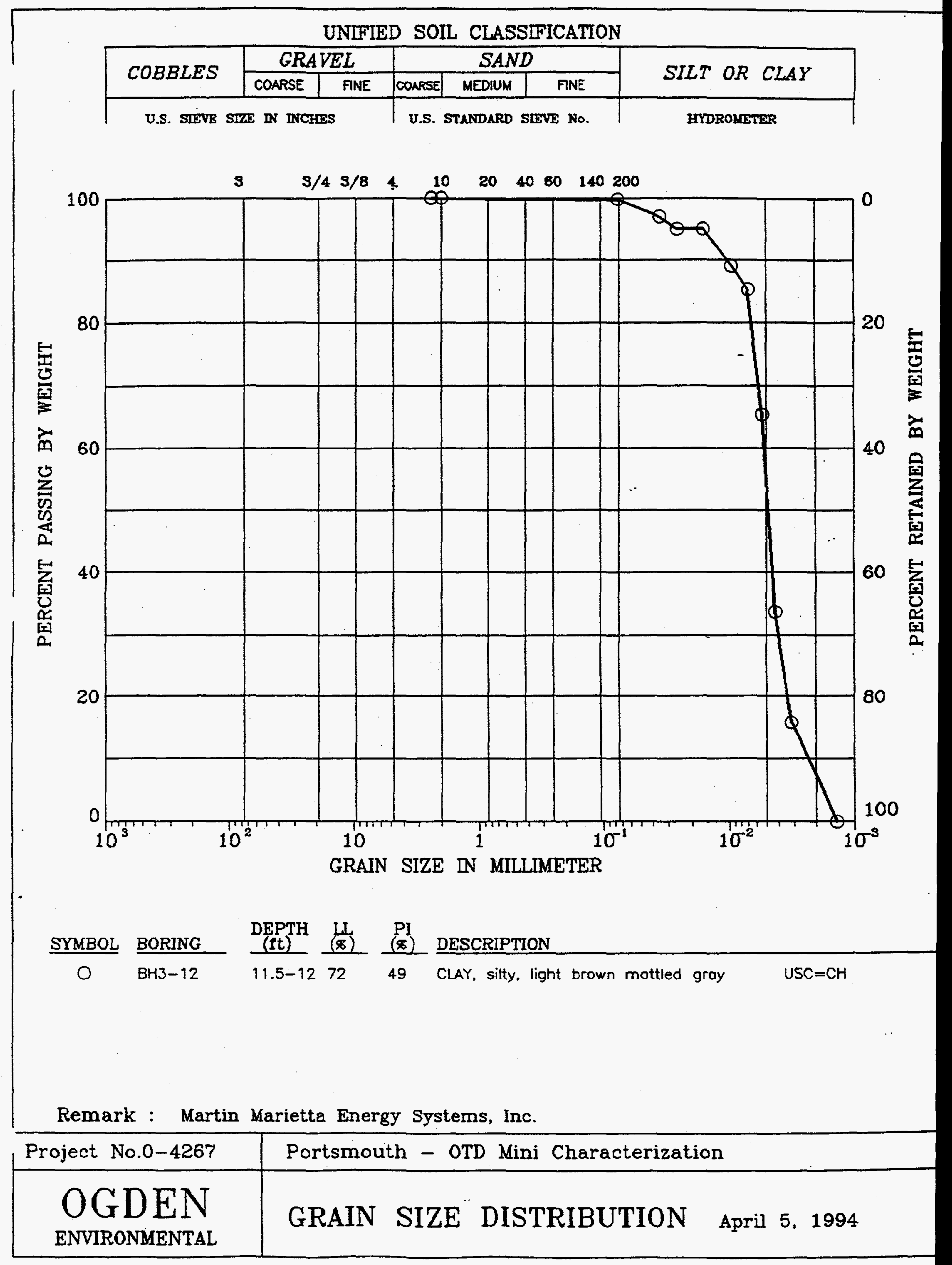




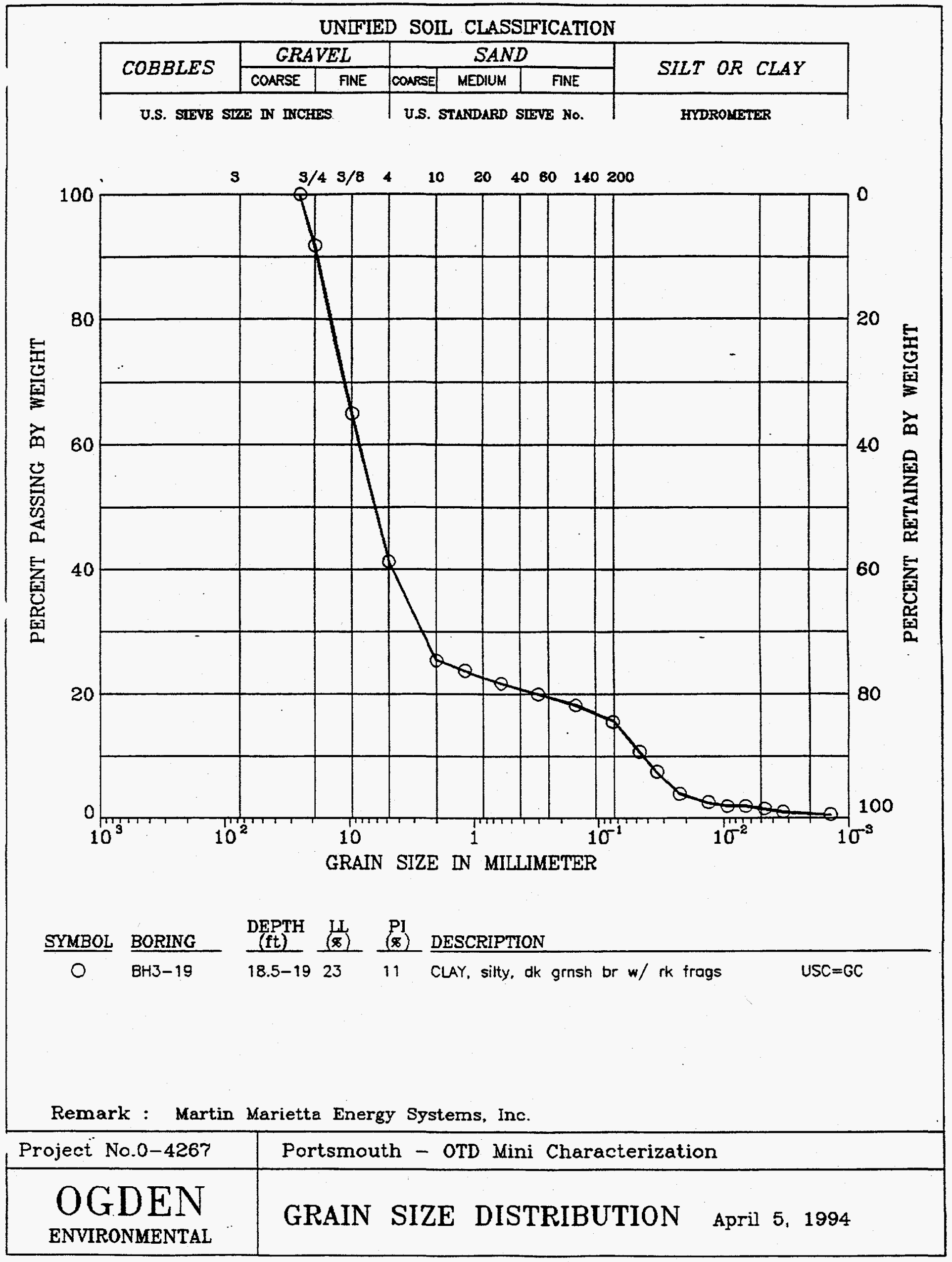




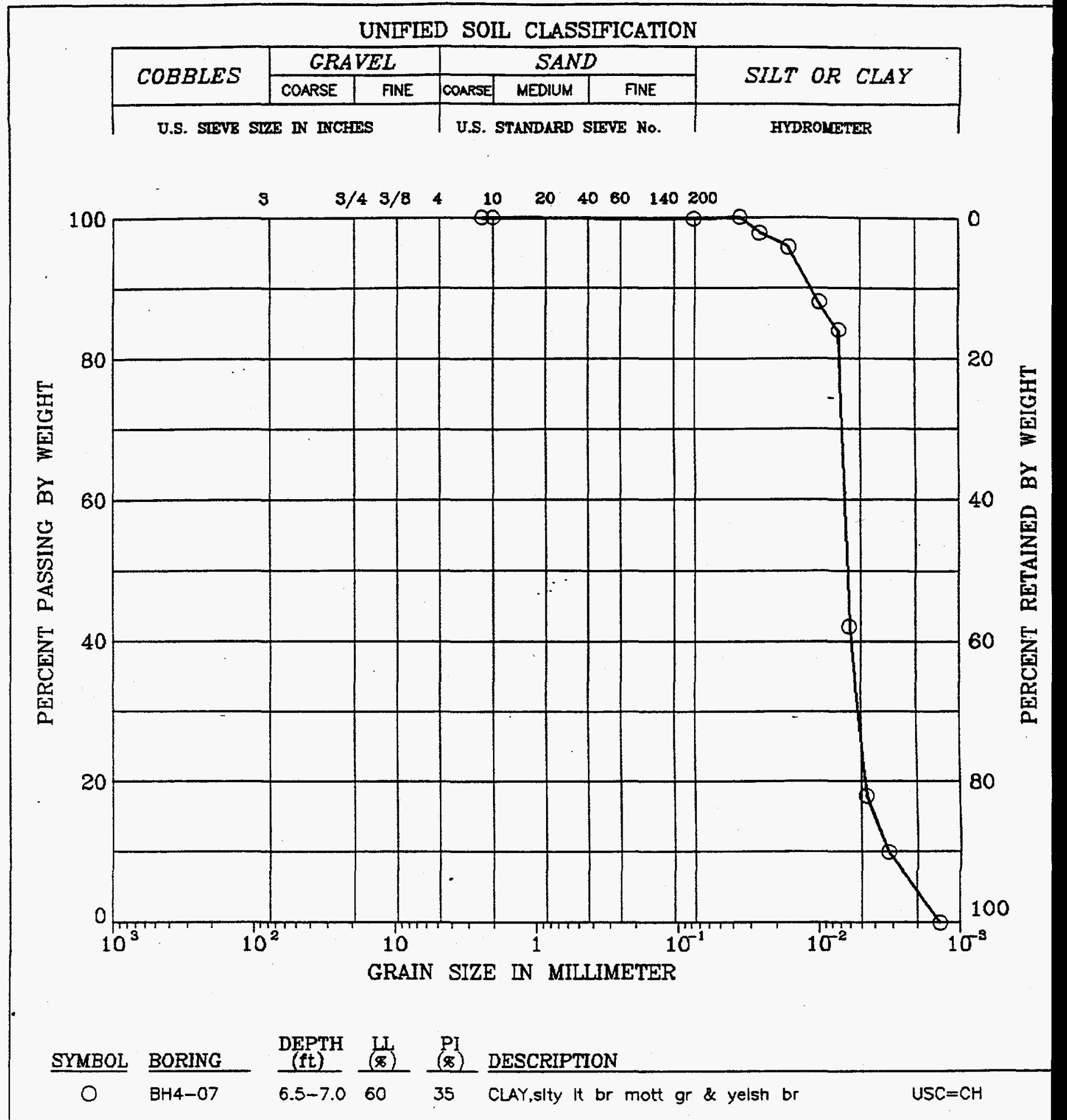

Remark : Martin Marietta Energy Systems, Inc.

\begin{tabular}{|c|l}
\hline Project No.0-4267 & Portsmouth - OTD Mini Characterization \\
\hline OGDEN & GRAIN SIZE DISTRIBUTION April 5, 1994
\end{tabular}




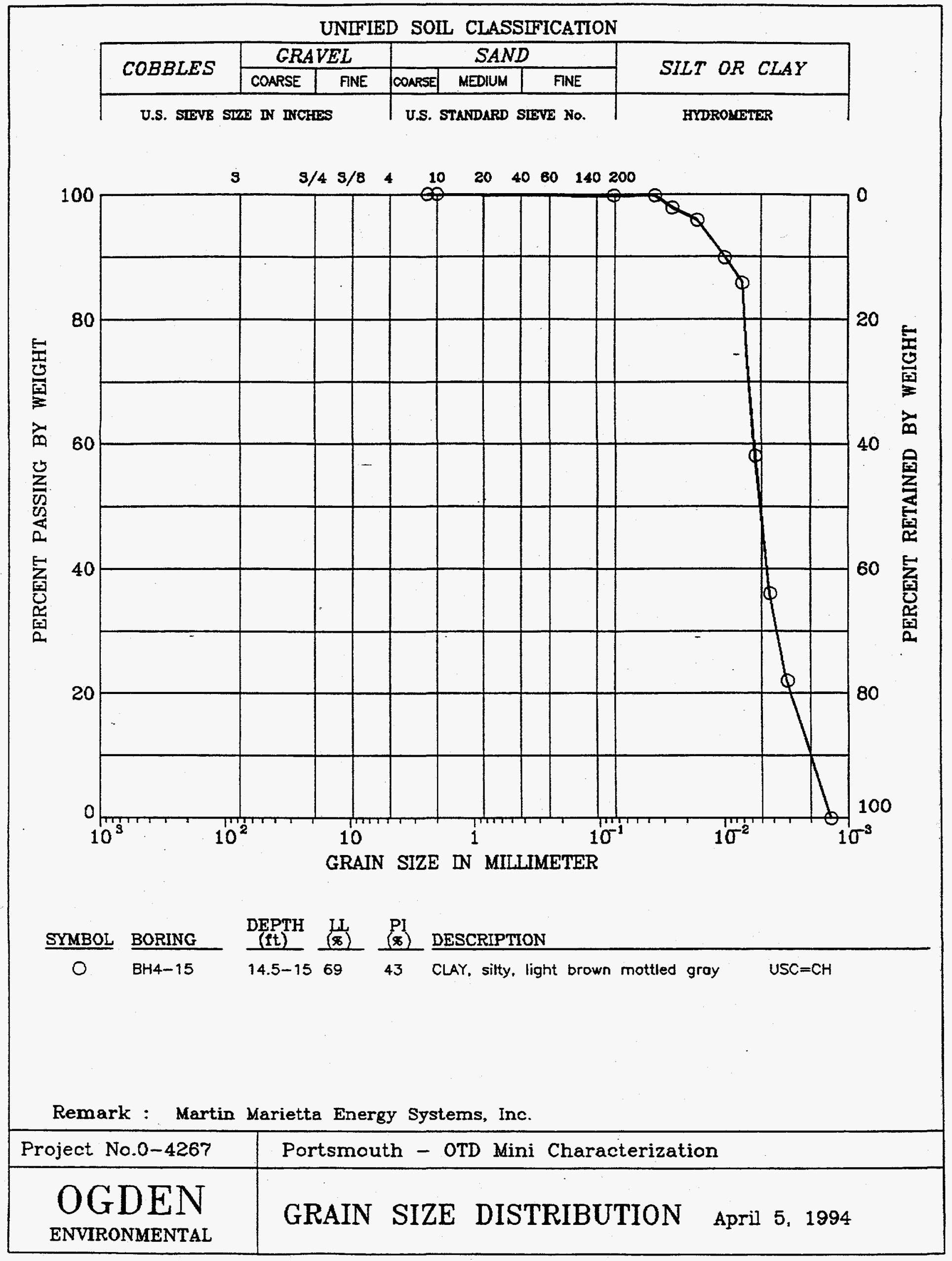




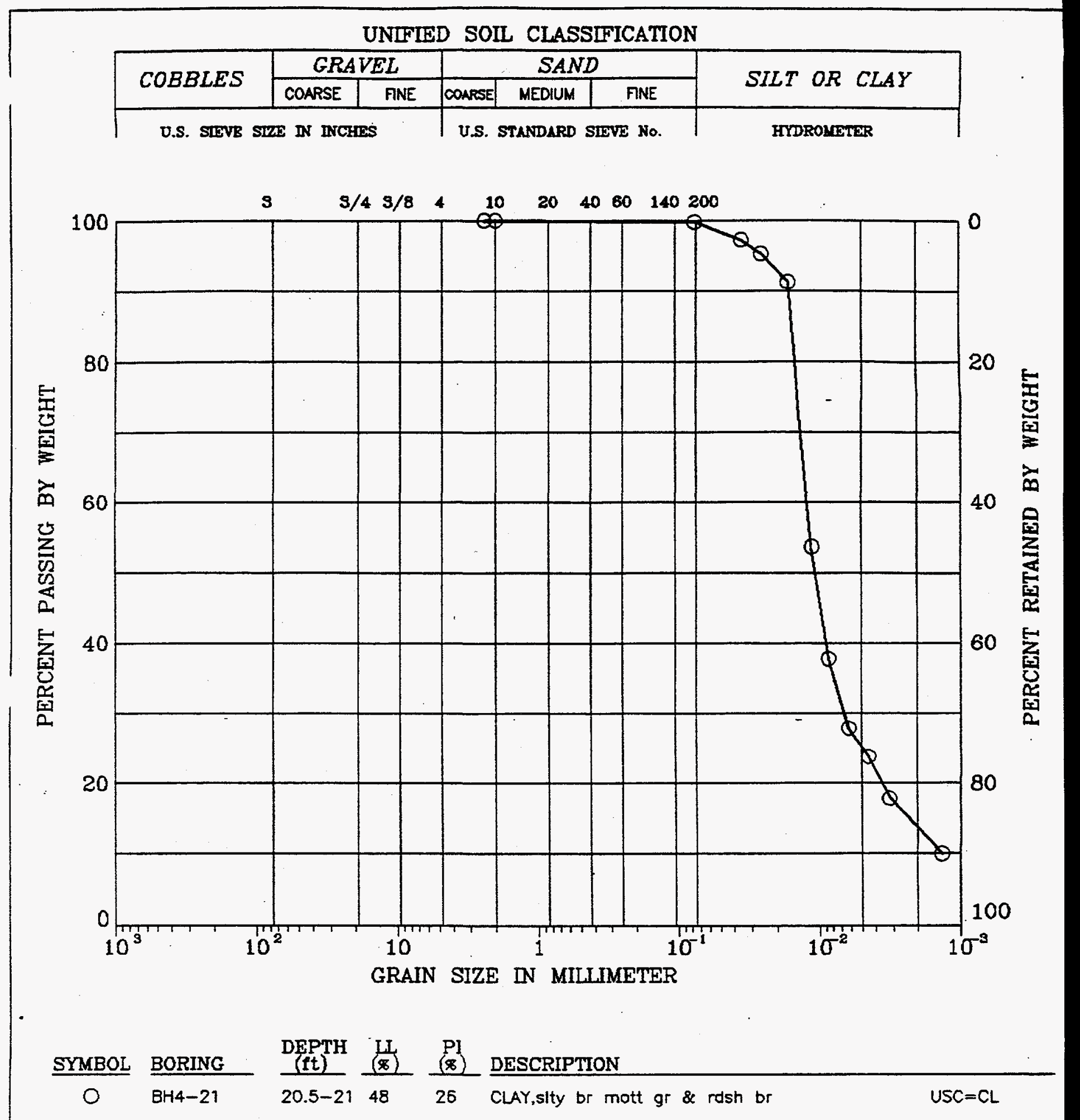

Remark : Martin Mariette Energy Systems, Inc. 


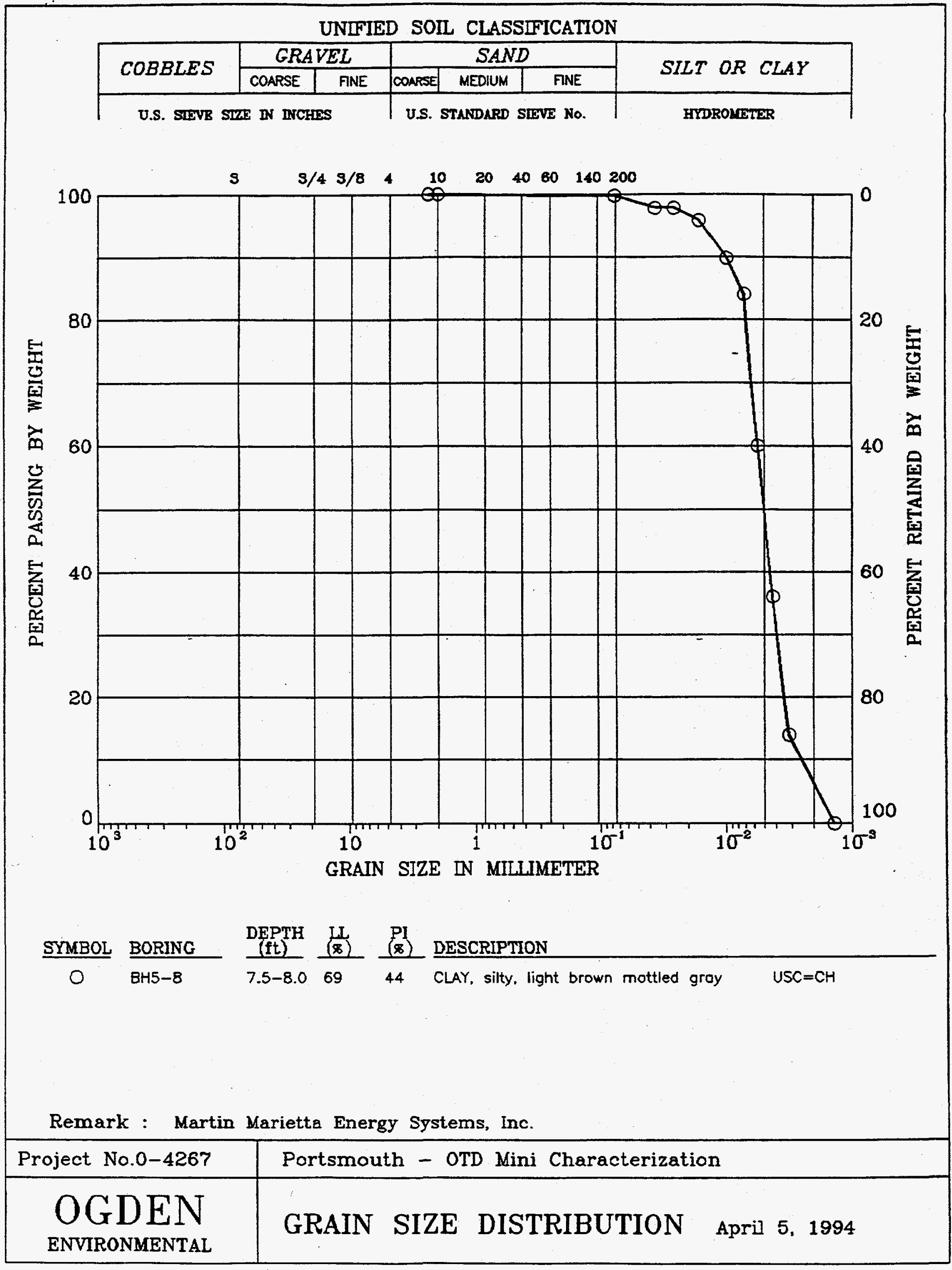




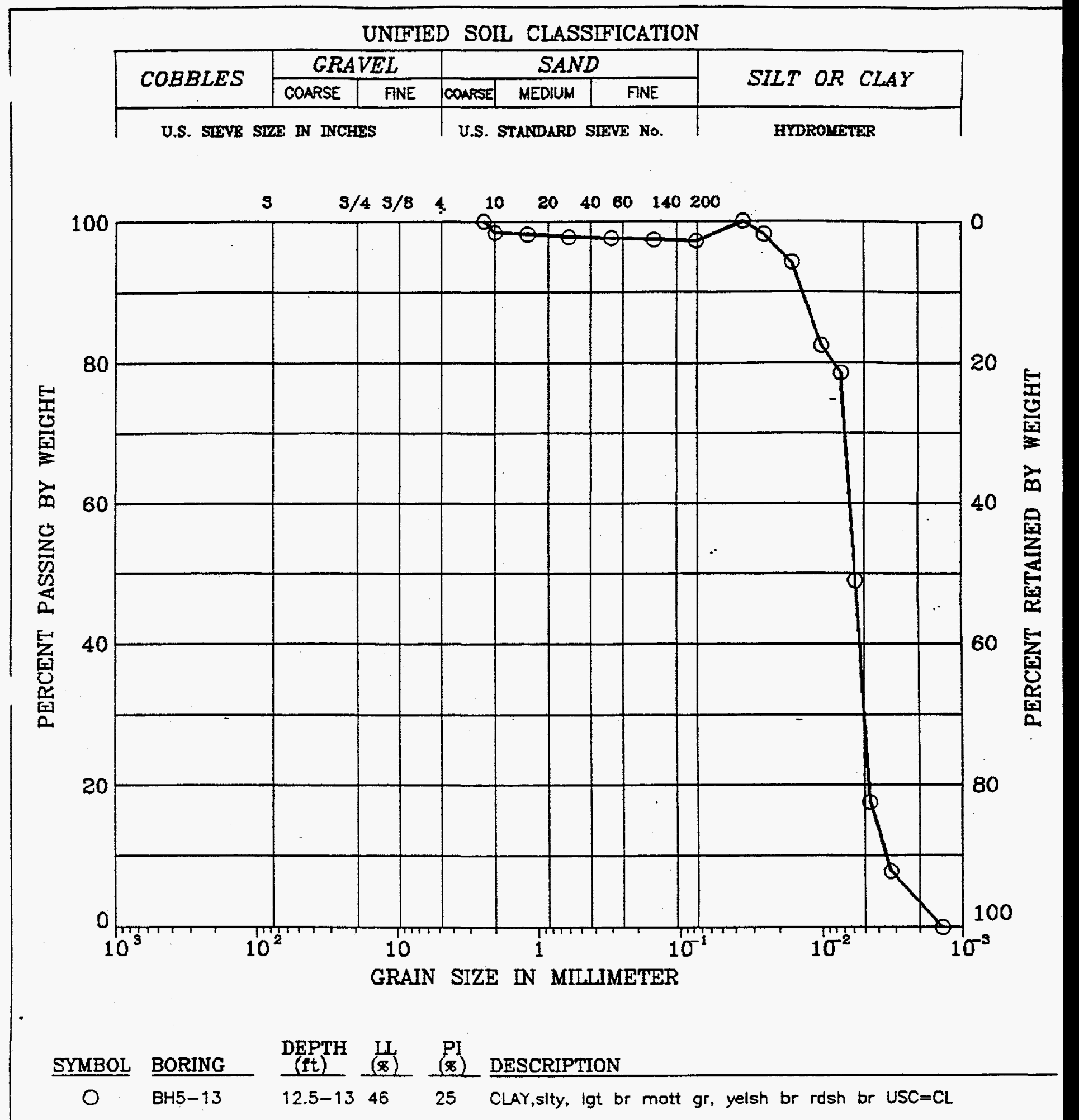

Remark : Martin Marietta Energy Systems, Inc.

\begin{tabular}{|c|l|}
\hline Project No.0-4267 & Portsmouth - OTD Mini Characterization \\
\hline $\begin{array}{c}\text { OGDEN } \\
\text { ENVIRONMENTAL }\end{array}$ & GRAIN SIZE DISTRIBUTION April 5, 1994 \\
\hline
\end{tabular}




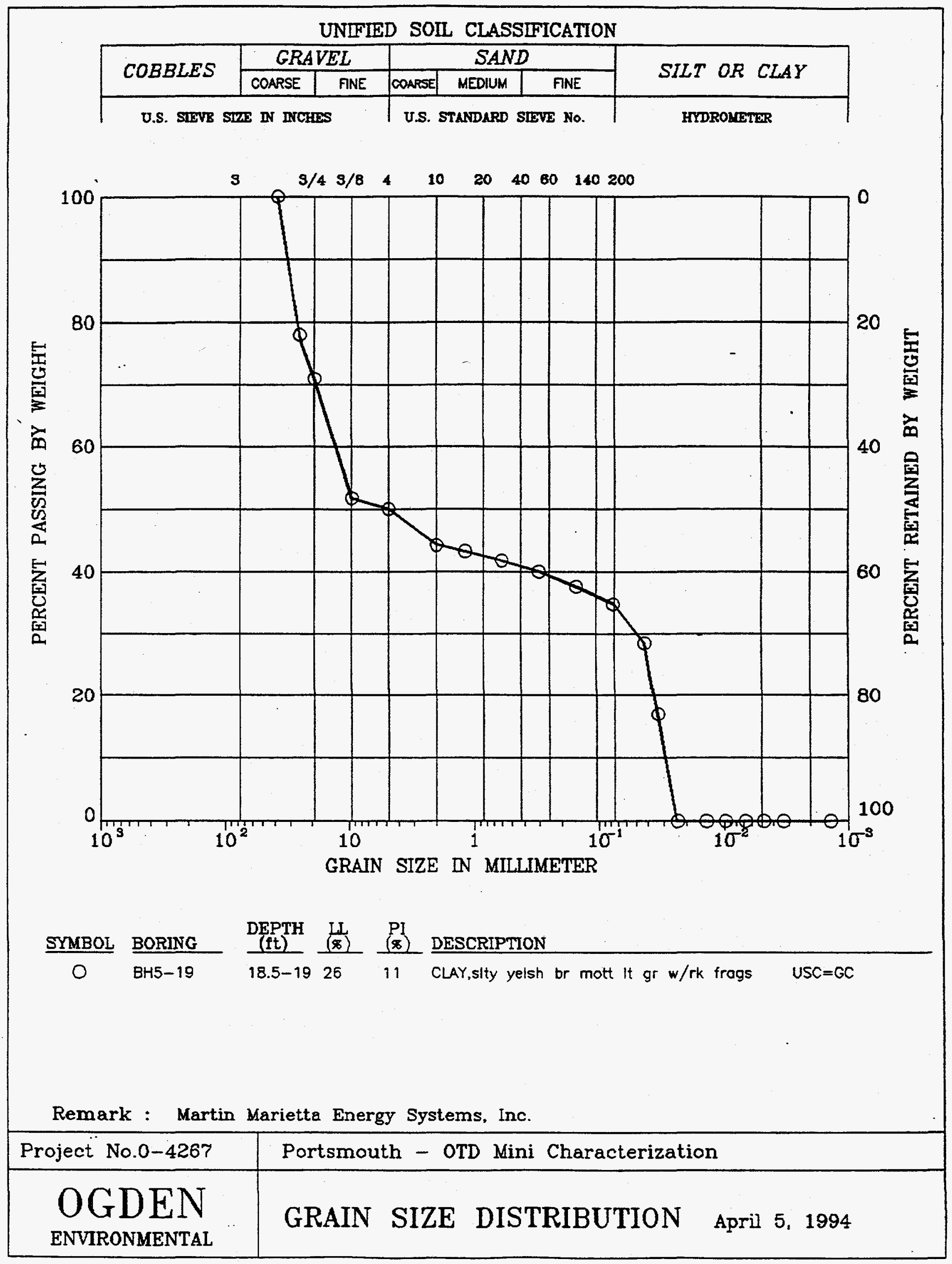




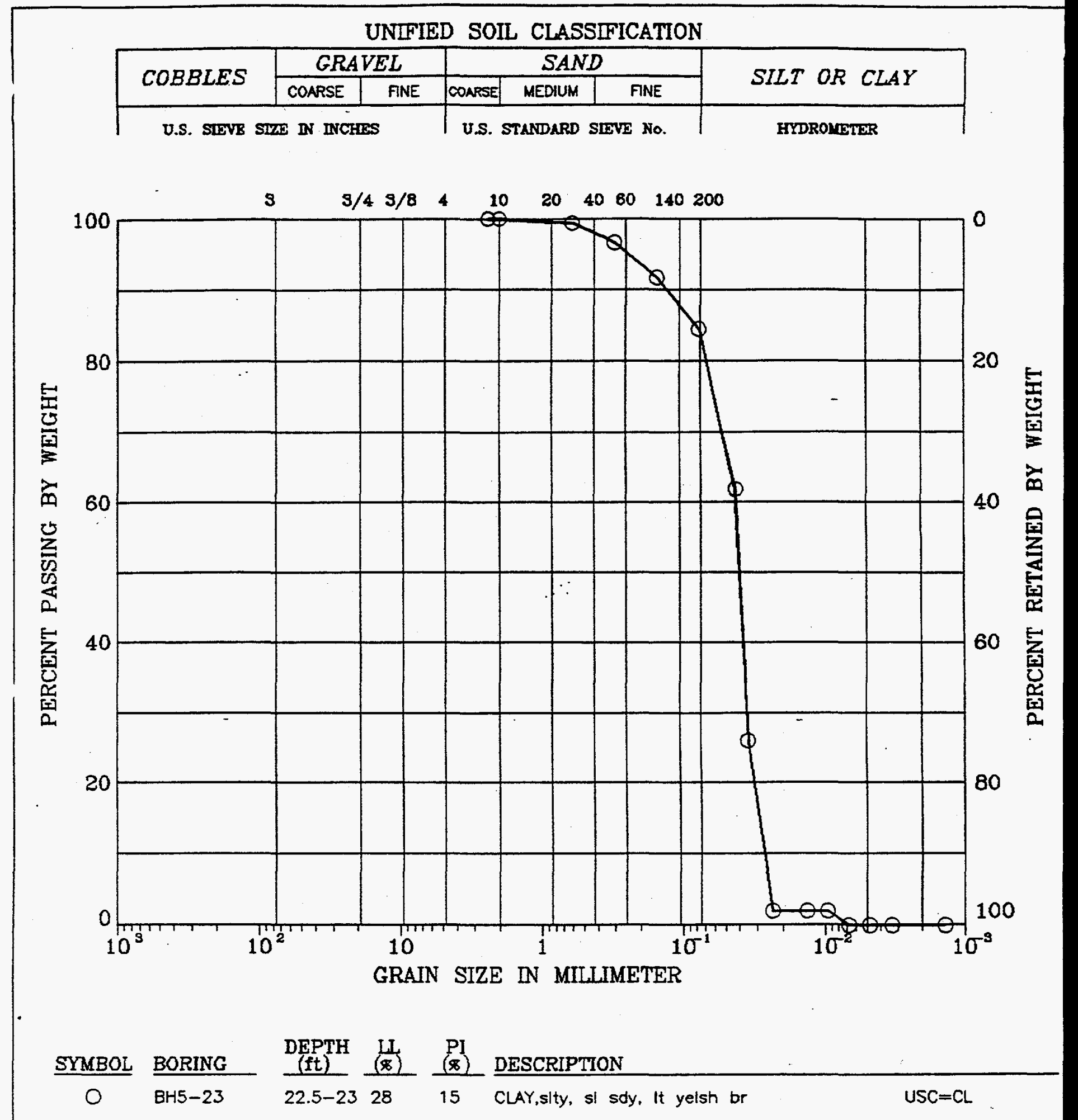

Remark : Martin Marietta Energy Systems, Inc.

\begin{tabular}{|l|l|}
\hline Project No.0-4267 & Portsmouth - OTD Mini Characterization \\
\hline
\end{tabular}




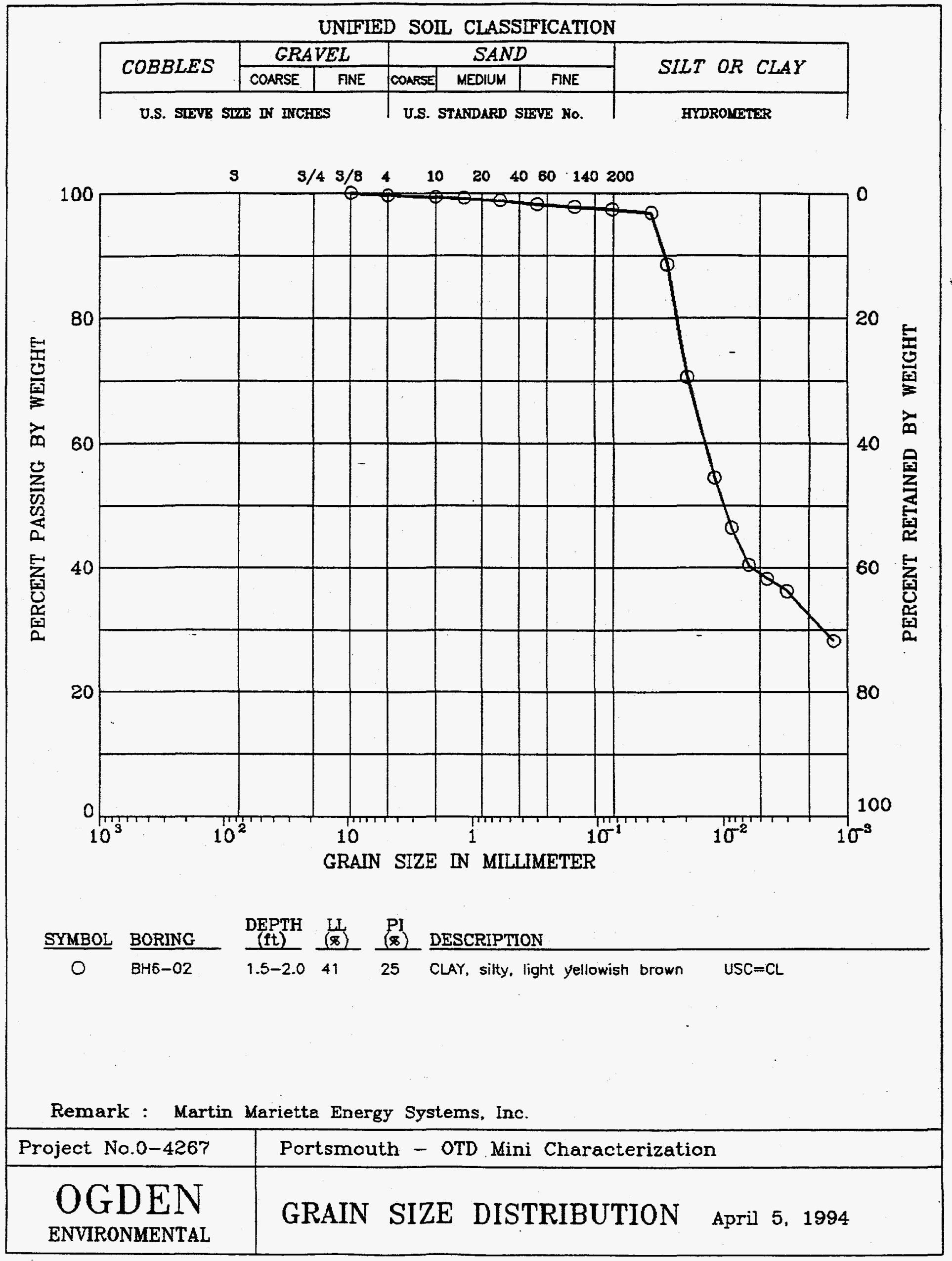




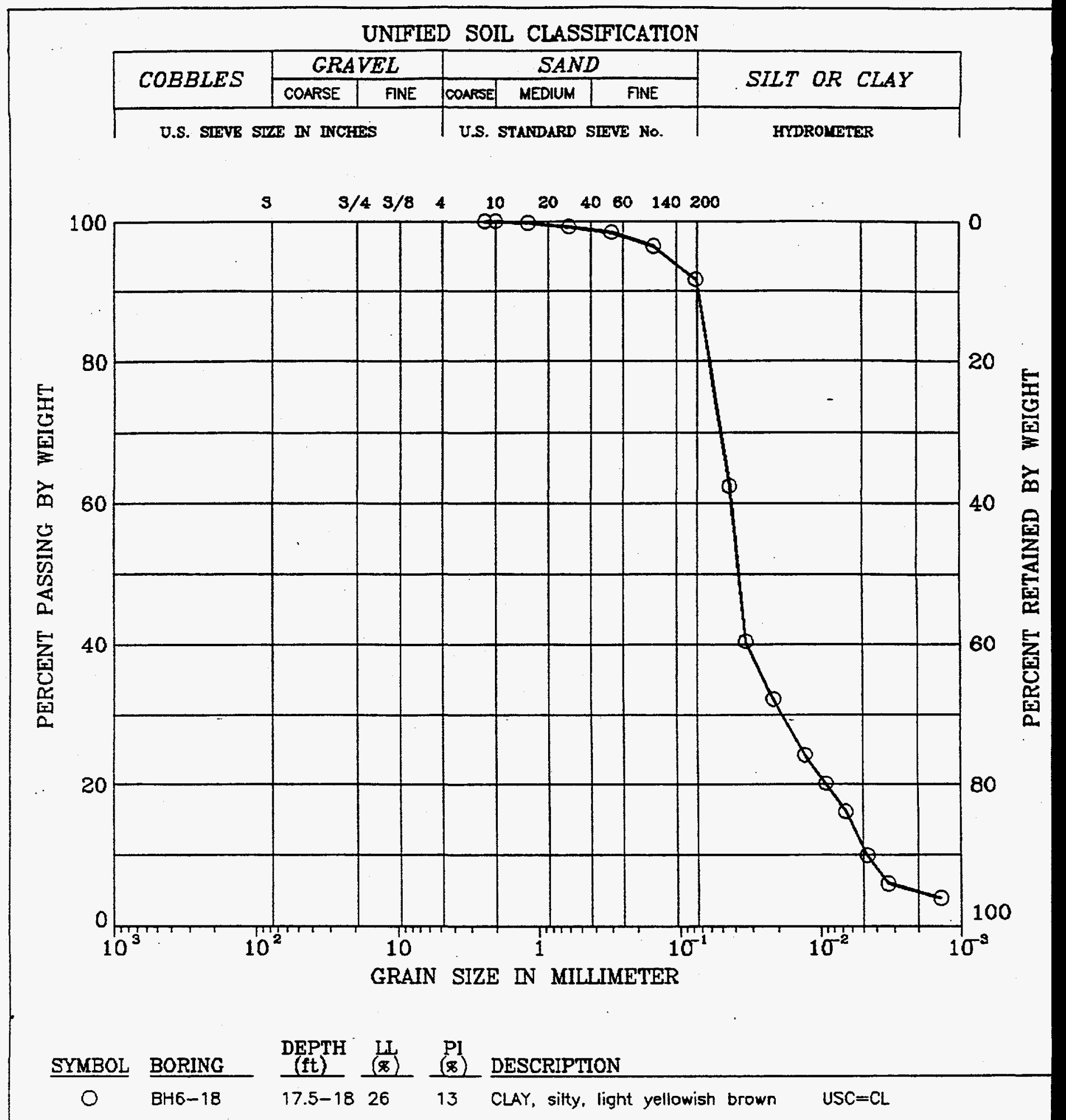

Remark : Martin Marietta Energy Systems, Inc. 


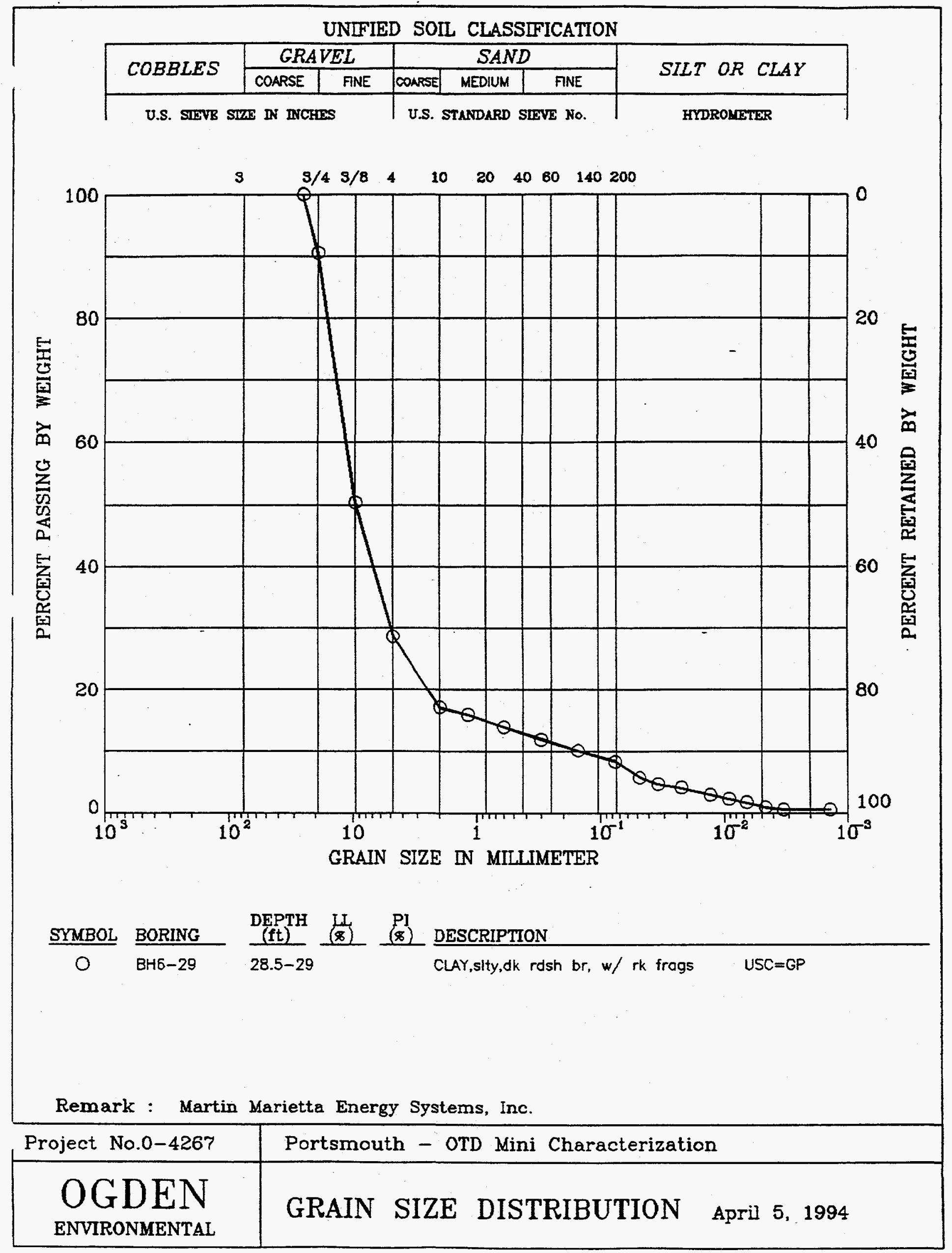




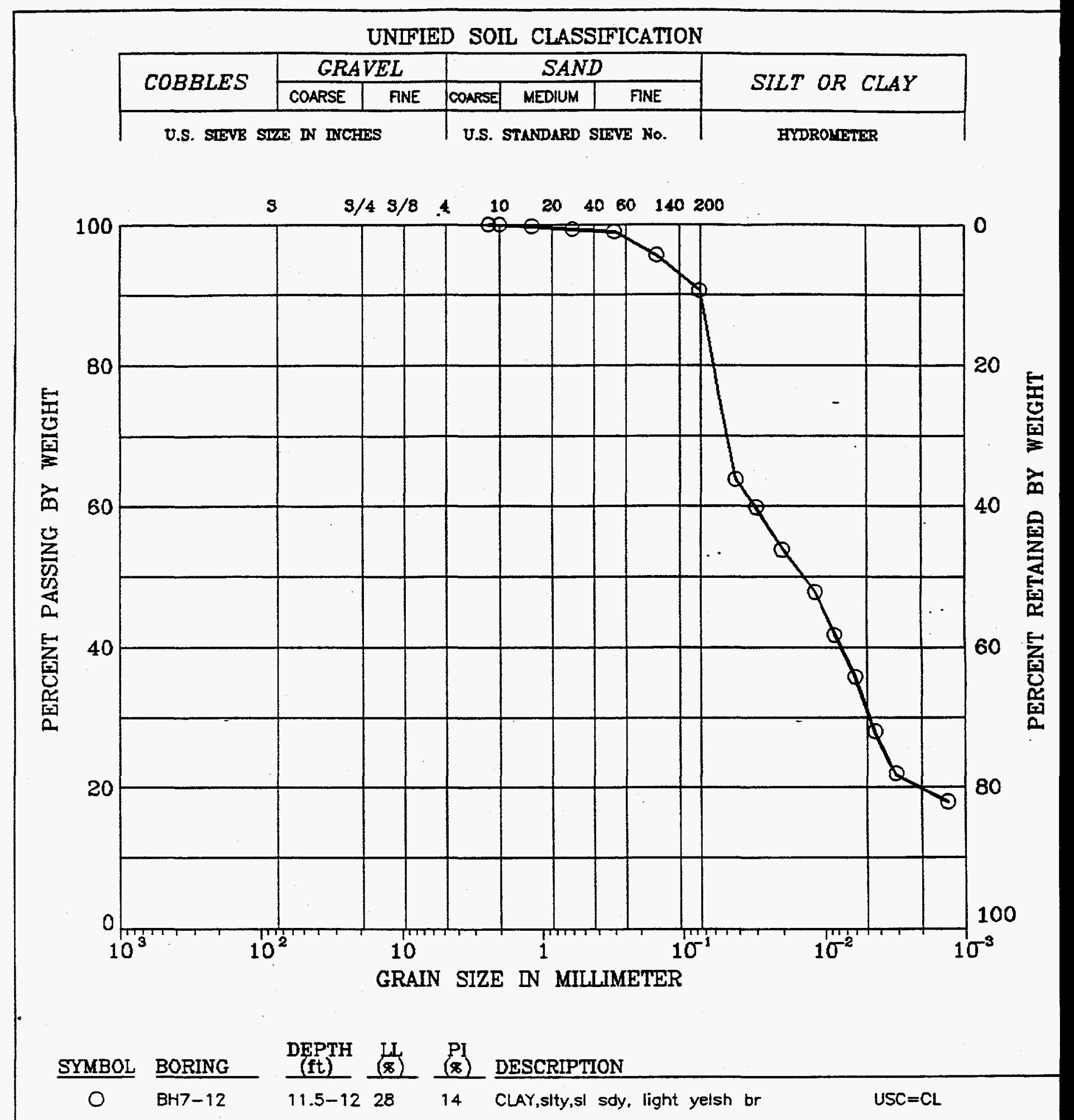

Remark : Martin Marietta Energy Systems, Inc.

\begin{tabular}{c|l}
\hline Project No.0-4267 & Portsmouth - OTD Nini Characterization \\
\hline OGDEN & GRAIN SIZE DISTRIBUTION April 5. 1994
\end{tabular}




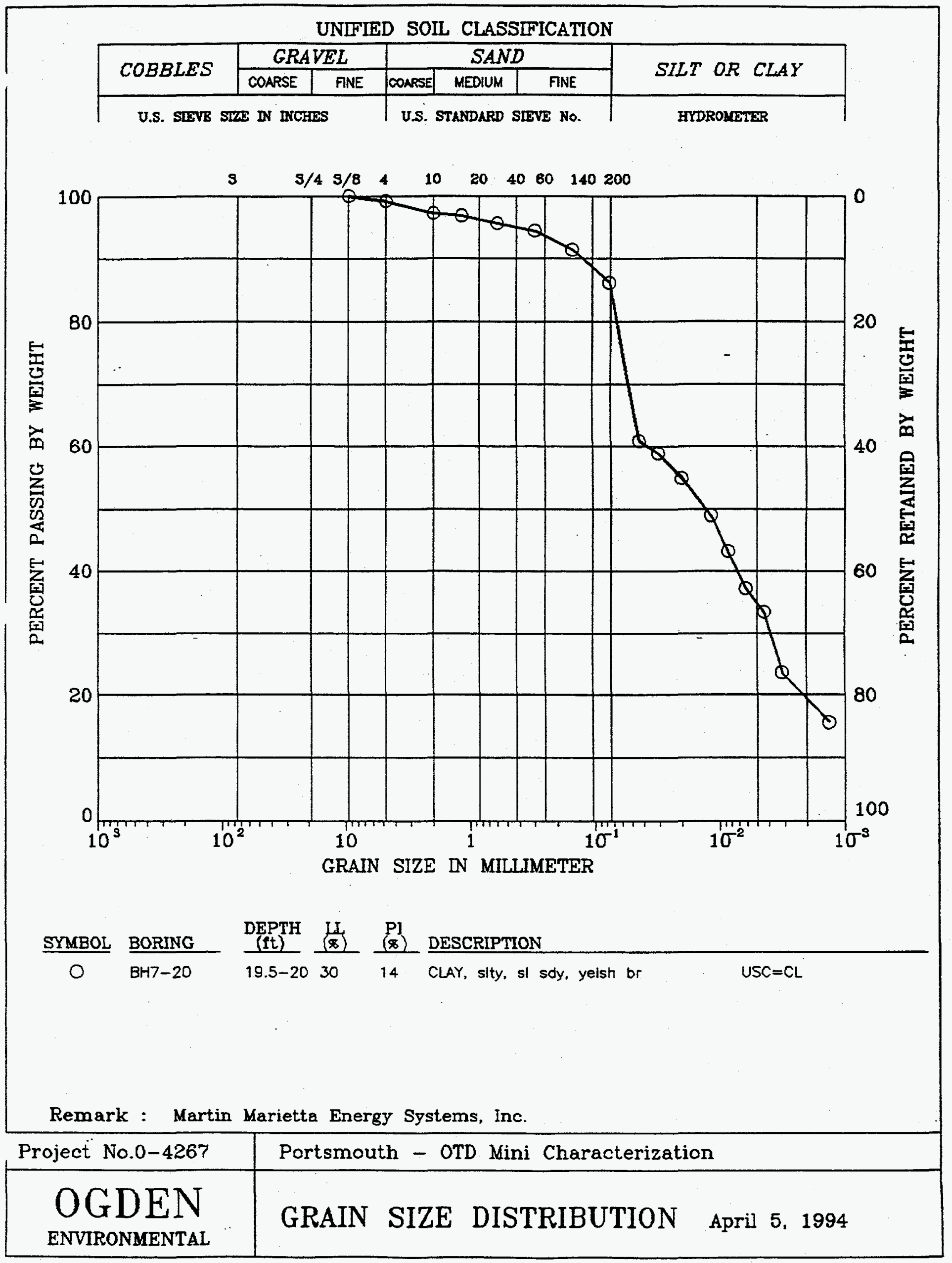




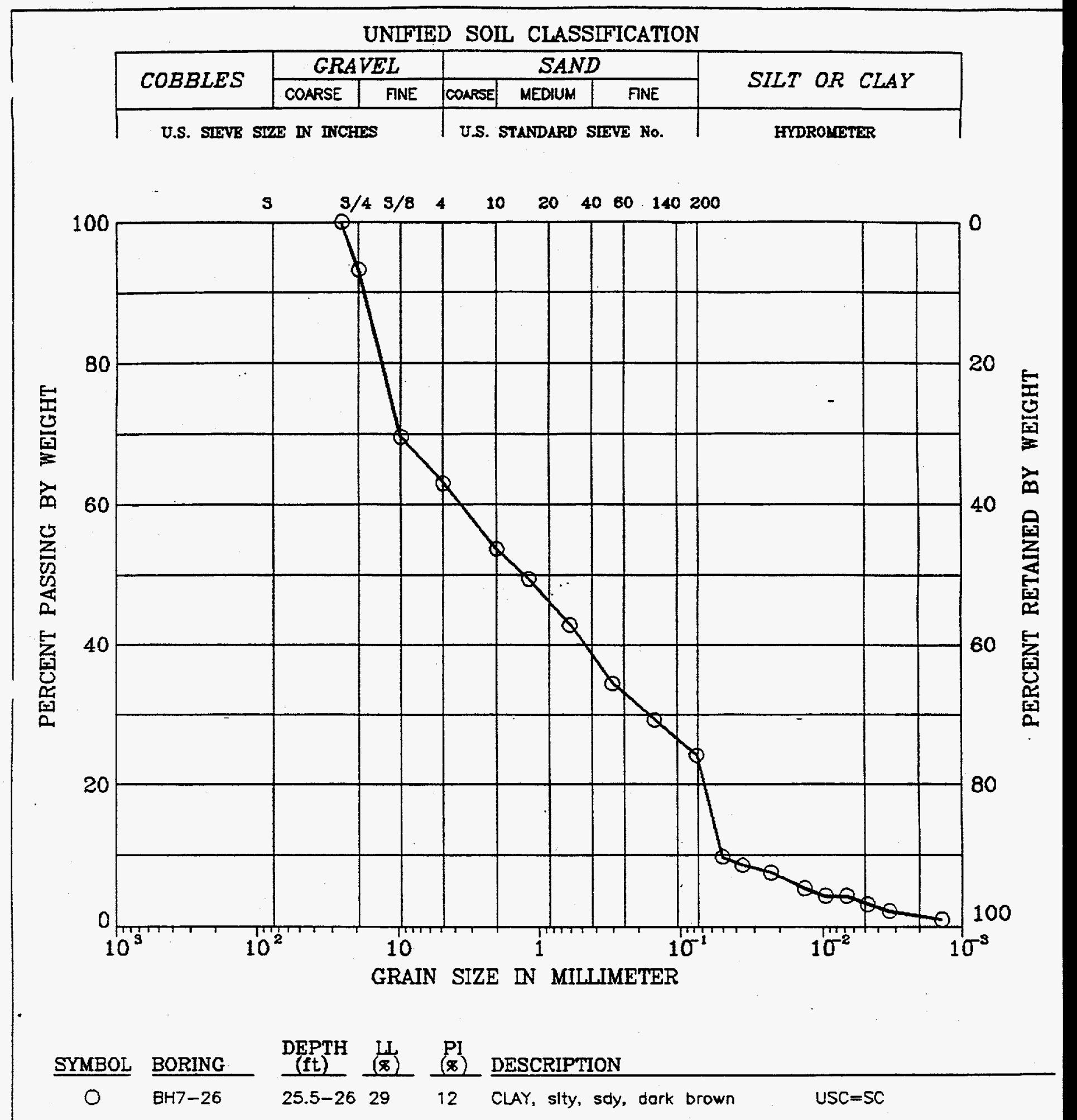

Remark : Martin Marietta Energy Systems, Inc.

\begin{tabular}{|c|l}
\hline Project No.0-4267 & Portsmouth - OTD Mini Characterization \\
\hline OGDEN & GRAIN SIZE DISTRIBUTION April 5. 1994
\end{tabular}




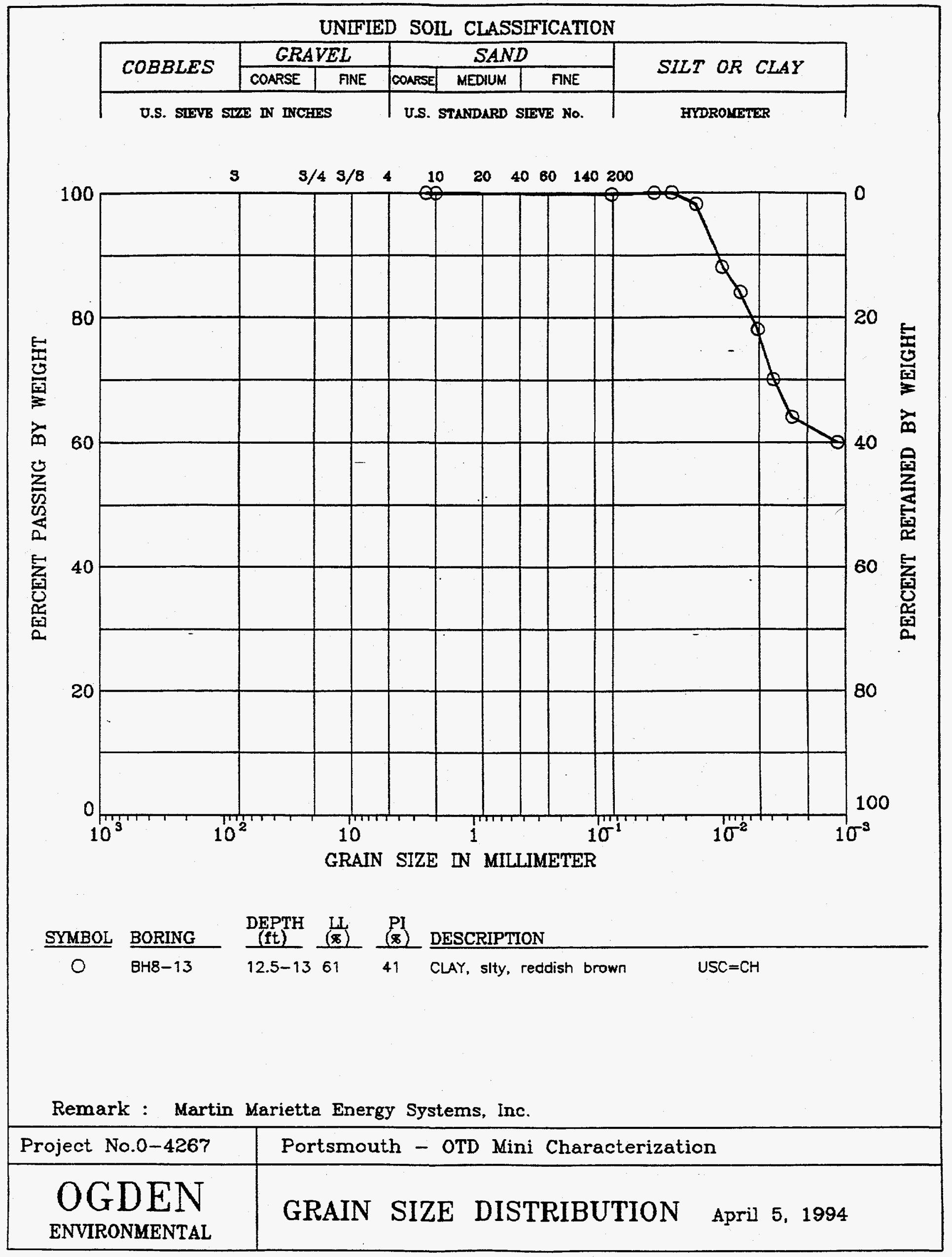




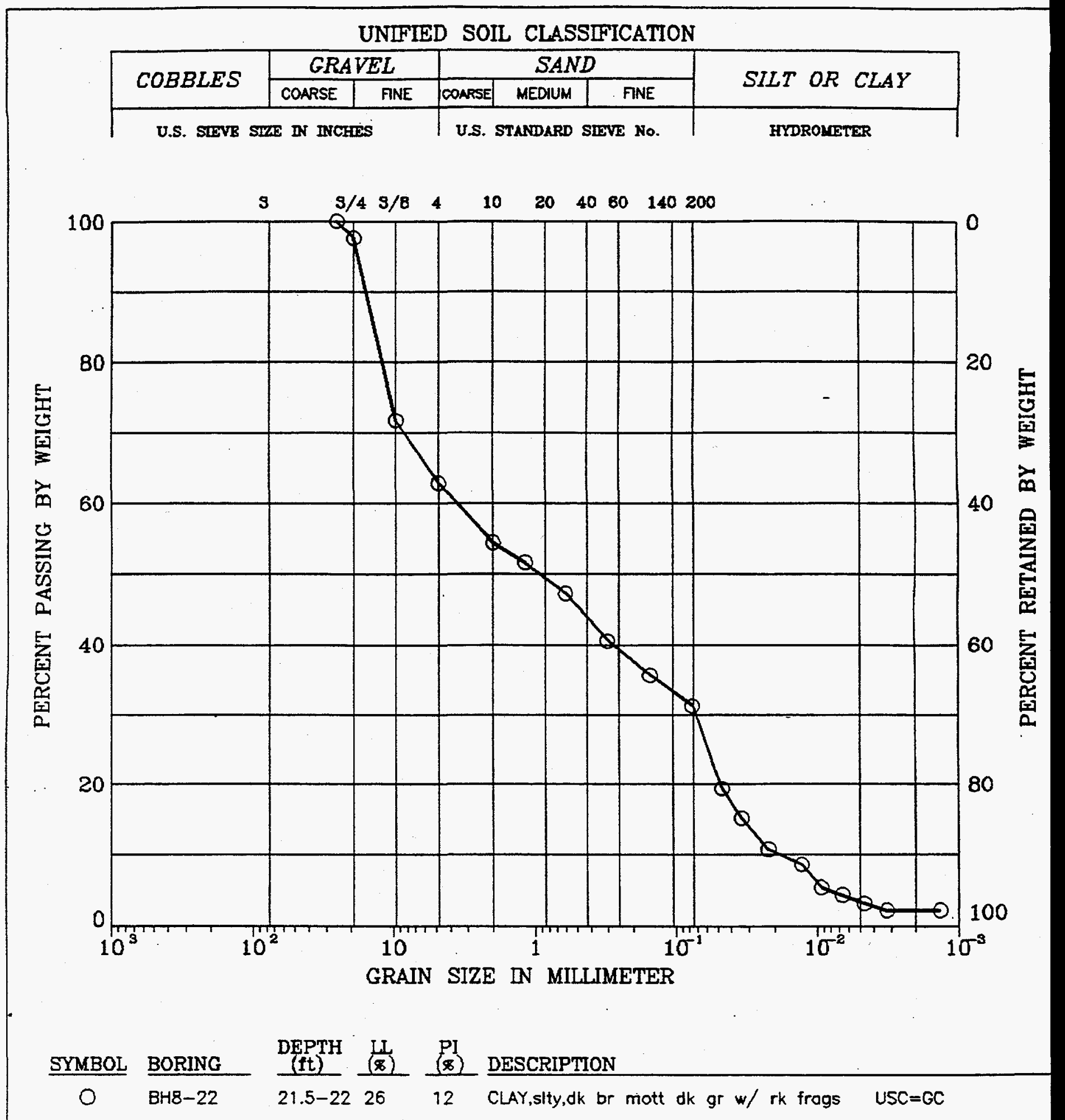

Remark : Martin Marietta Energy Systems, Inc.

\begin{tabular}{c|l}
\hline Project No.0-4267 & Portsmouth - OTD Mini Characterization \\
\hline OGDEN & GRAIN SIZE DISTRIBUTION April 5. 1994
\end{tabular}




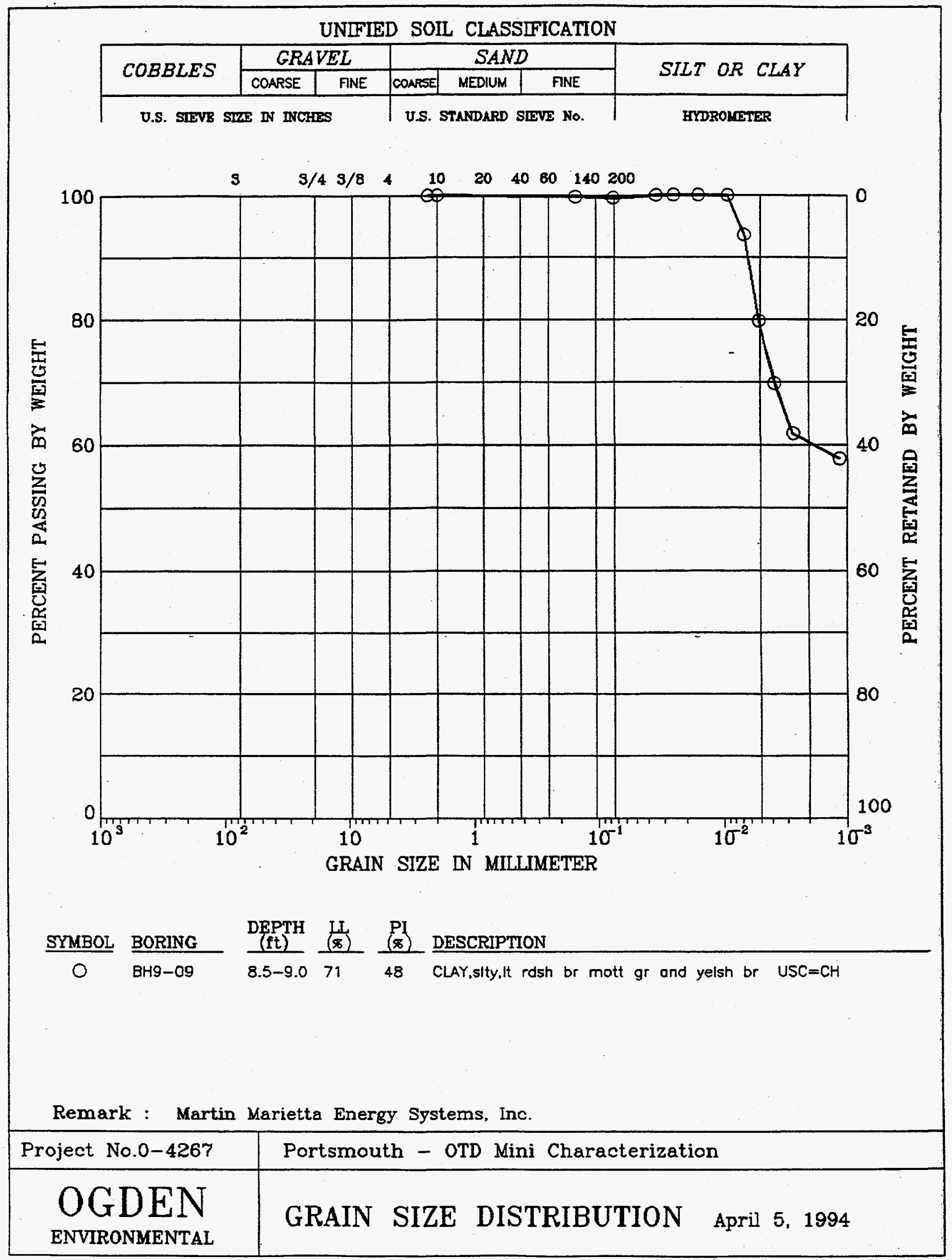




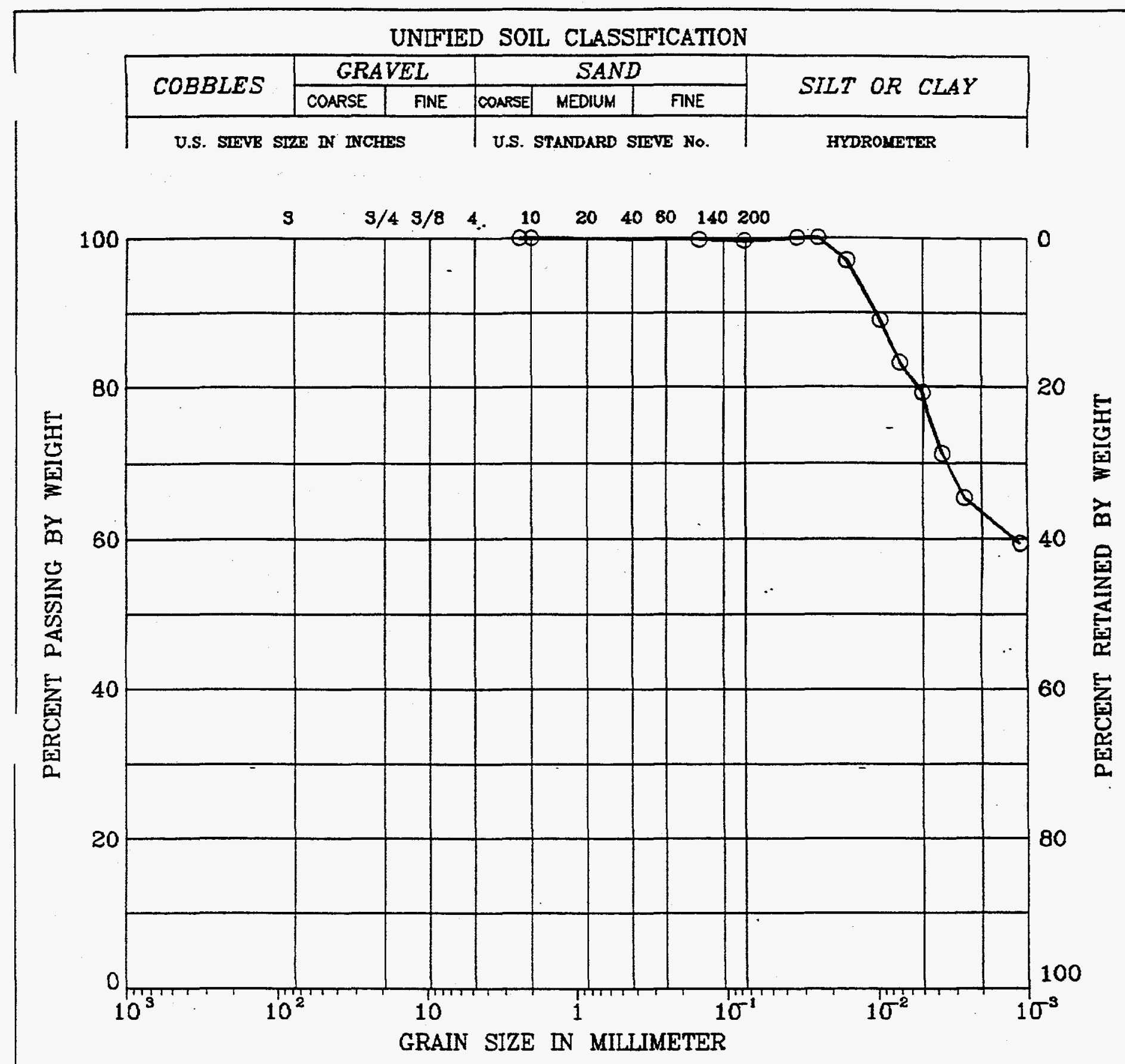

SYMBOL BORING $\begin{aligned} & \text { DEPTH } \\ & (\mathrm{ft})\end{aligned} \frac{\text { LI }}{(\mathrm{s})}$ PI $(8)$ DESCRIPTION

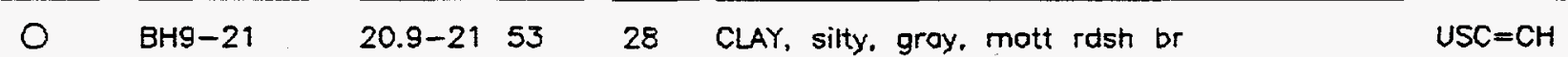

Remark : Martin Marietta Energy Systems, Inc.

\begin{tabular}{l|l}
\hline Project No.0-4267 & Portsmouth - OTD Mini Characterization
\end{tabular}




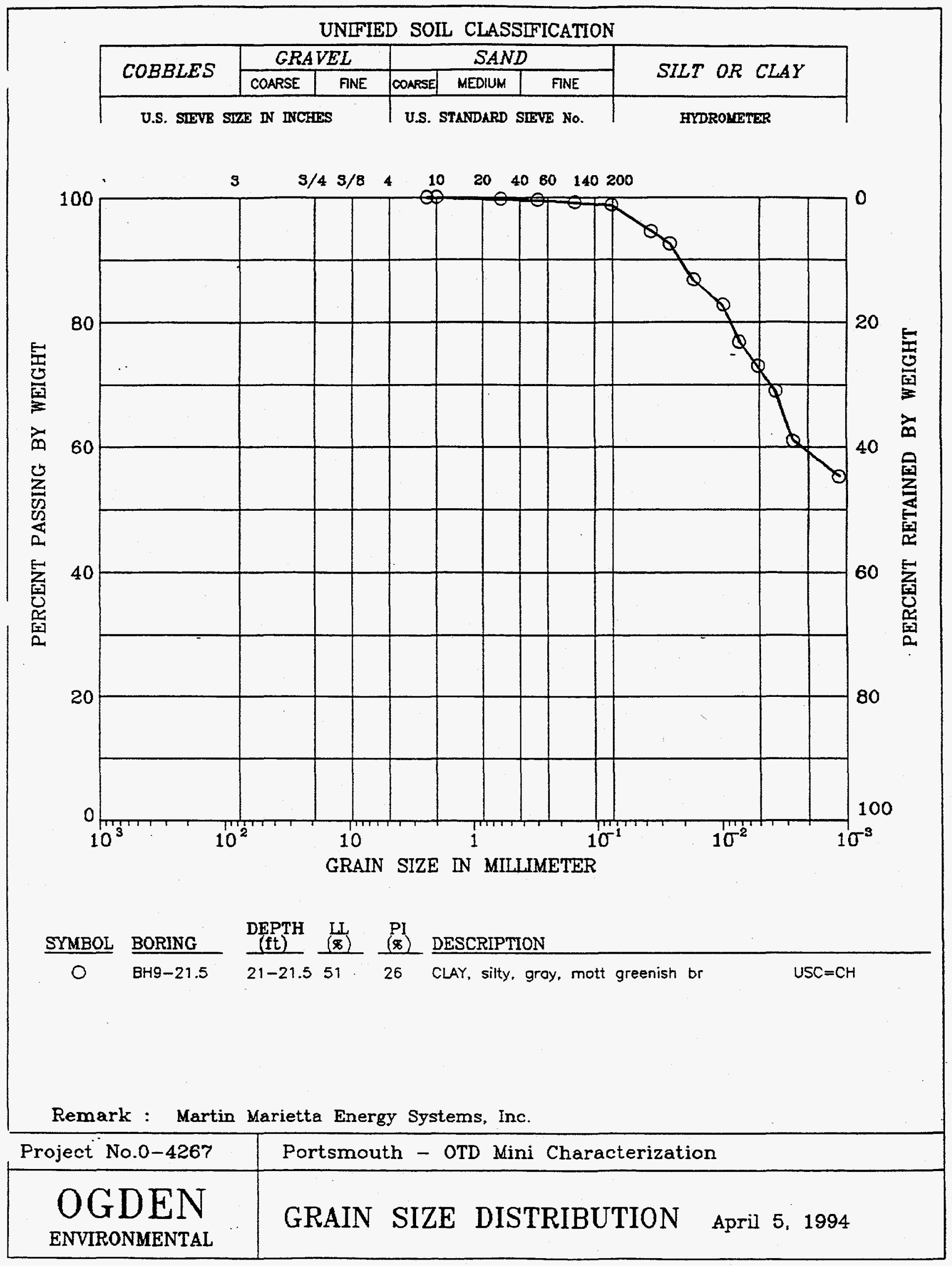


Appendix B

Vendor Information for Schumacher Porous Filters 


\section{Well filters for remediation of contaminated soils and groundwater}

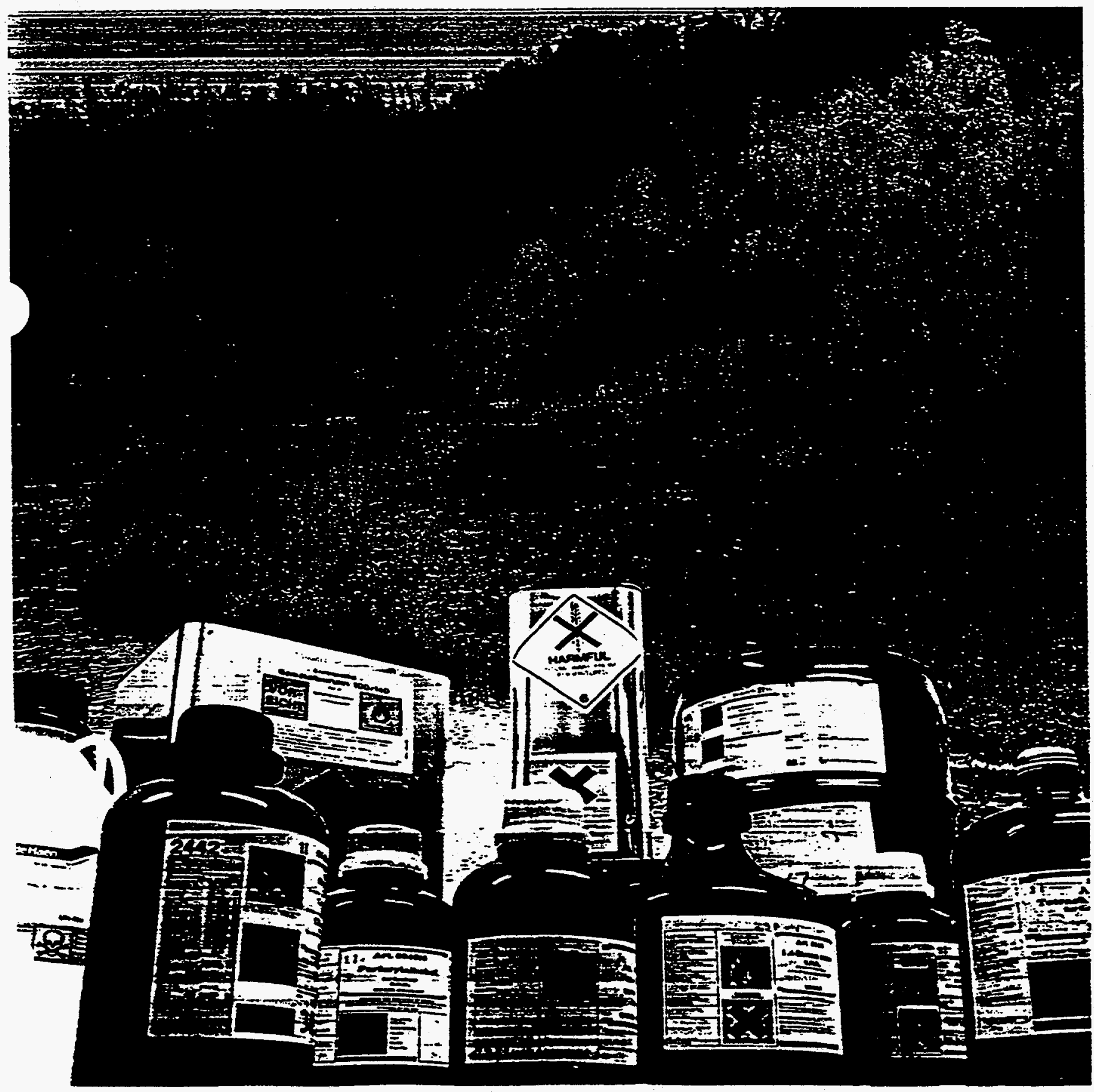




\section{In situ remediation of contaminated soils}

The in situ cleaning of contaminated soils is a very urgent task in environmental protection. SCHUMACHER developed new parts for clean up techniques to be used for soils and groundwater. A new porous well filter consisting of pure polyethylene is very useful especially in fine grain soil types.

SCHUMACHER well filters have very specific advantageous properties for well design in the saturated and unsaturated zone.

\section{Properties}

- homogeneous pore size distribution

- same chemical resistance as high density polyethylene

- hydrophobic character oliophilic behaviour

- low weight

- high permeability for water and air

These properties show excellent advantages compared to conventional well screens.

\section{Advantages}

- the homogeneous pore size distribution supports a laminar fluid flow through the filter across its total surface

- clogging and incrustation are avoided

- the hydrophobic character can be used to keep soil water outside the well

- the permeability of the filter to oil ensures an excellent separation of groundwater and oil
Proving ground for horizontal fitter wells
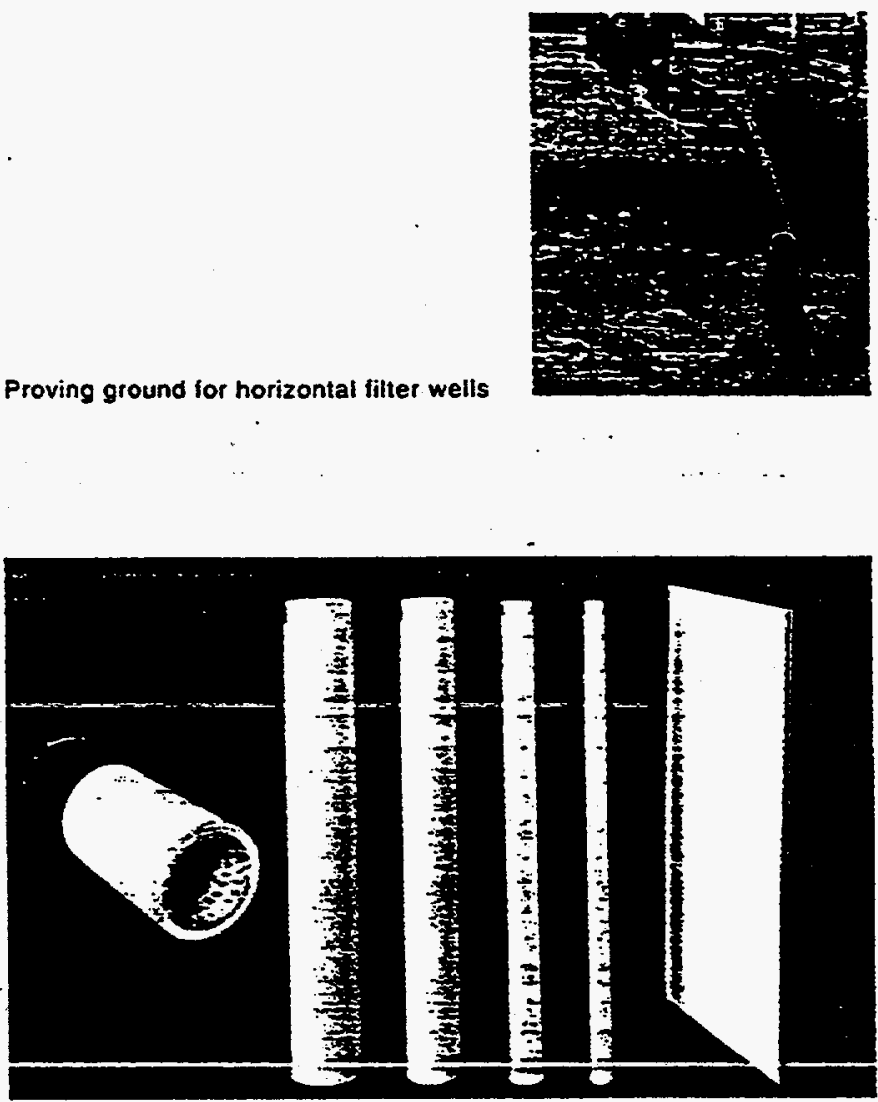

SCHUMACHER titter elements

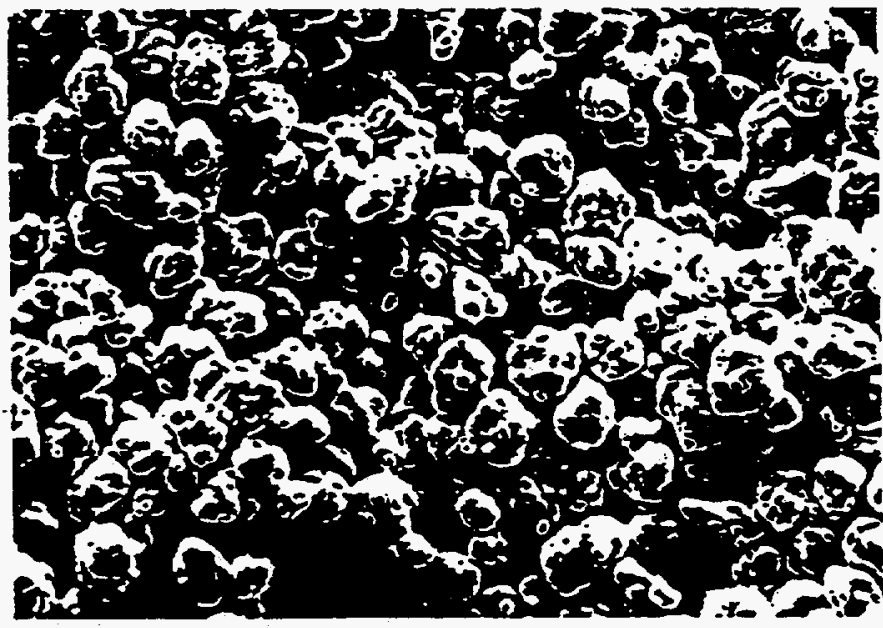

SEM photography of fracture surface 


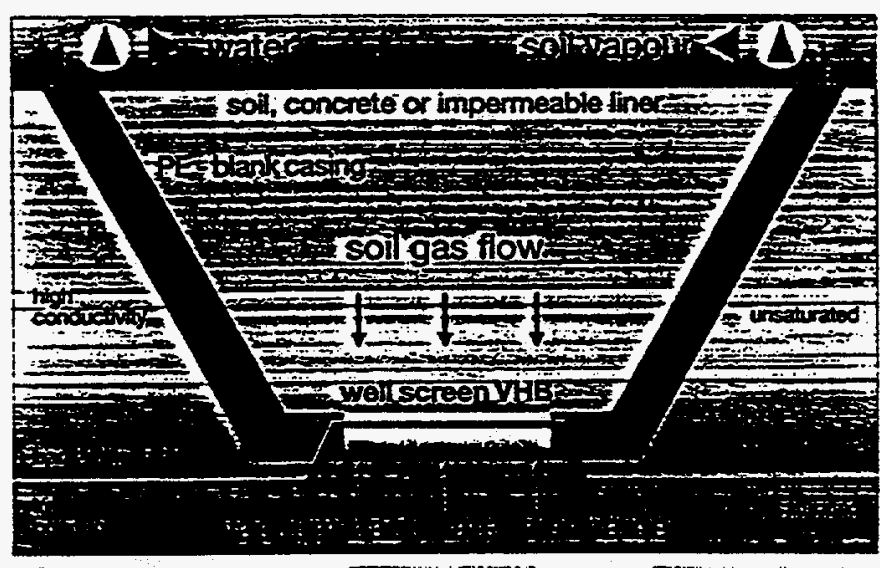

Hörizontat filter well

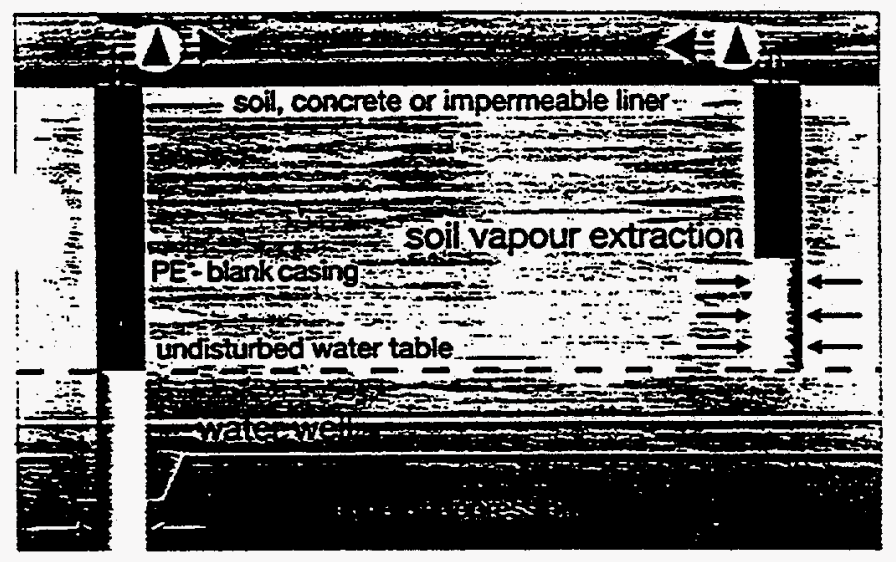

Vertical filter well

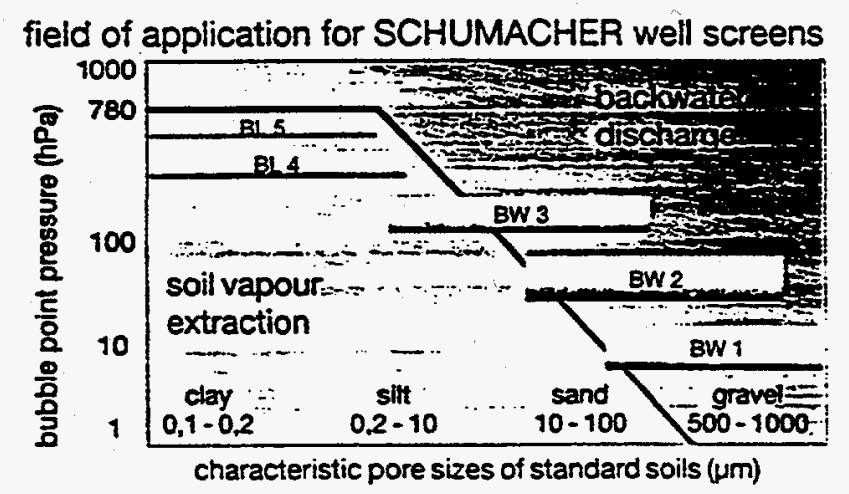

Field of application of SCHUMACHER filter wells
- SCHUMACHER well filters are physiologically unobjectable.

- High mechanical strength allows the application in vertical and horizontal wells.

- Low weight and the standardized connections make transportation and installation very cost effective.

- The homogeneous porosity of SCHUMACHER well filters makes a gravel pack unnecessary and minimizes drilling diameters.

- Due to their ductility, SCHUMACHER well filters adapt to curved and horizontal wells by guided trenchless horizontal drillings (FlowTex-System).

\section{Applications}

SCHUMACHER well filters are produced with five different water entry values and five different permeabilities, covering a wide spectrum of applications. Especially under difficult conditions in fine grain soil types a contamination treatment can be carried out with

- soil vapour extraction

- back water discharge

- groundwater discharge

- gas or nutrient injection 


\section{Ex situ remediation of contaminated soils}

Ex situ techniques can also be supported by SCHUMACHER filter media. Excavated contaminated soil is cleaned in a mobile container system.

The container features two different sections:

The large one is equipped with a permeable layer of porous polyethylene for the extraction of soil vapour and other fluids.

The smaller section accomodates the process engineering components such as activated carbon barrels, catalytic combustion, blower, or power generator.

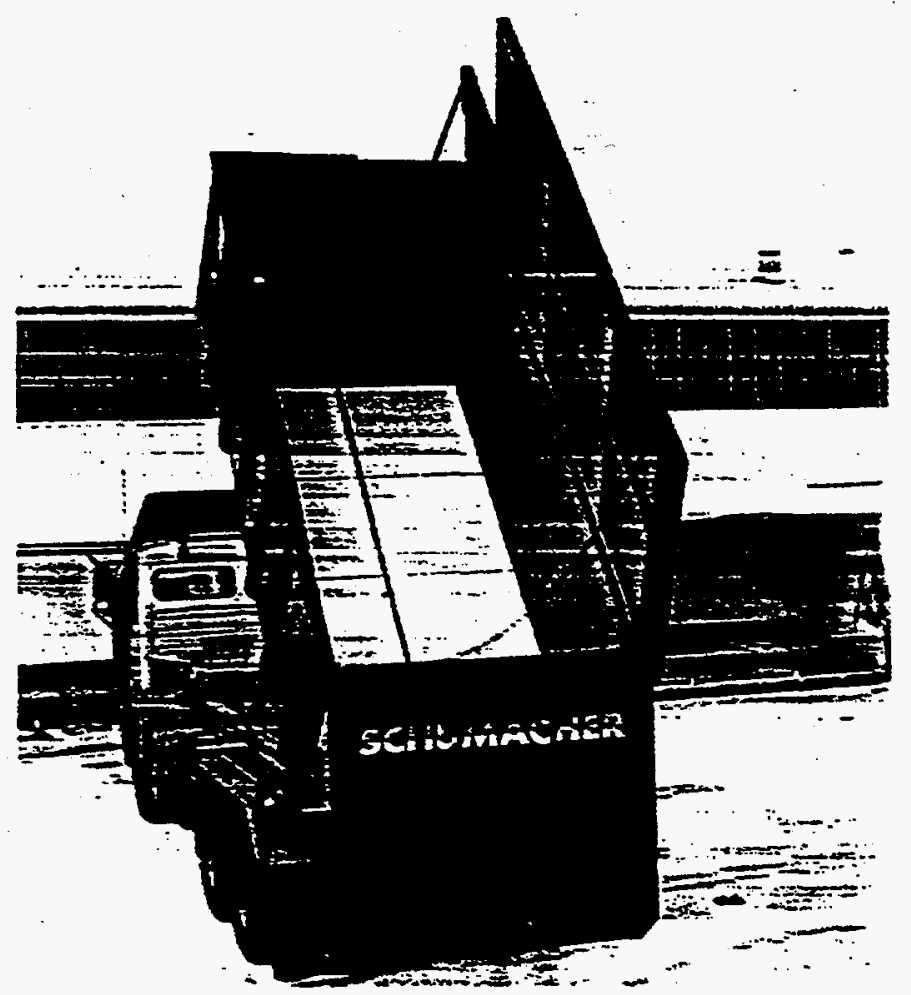

Container system for ex situ remediation

\section{Construction principles}

1. The extraction section is filled with contaminated soil.

2. The contaminated soil air is extracted by passing the evacuated porous layer of the container.

3. The soil air cleaning is carried out in the small section, using the required techniques.

4. After decontamination, the soil can be used for refilling, or has to be deposited on a land fill.

\section{Germany}

Schumacher Umwelt- und

Trenntechnik $\mathrm{GmbH}$

\section{ir Flügelau 70}

J-74564 Crailsheim

Tel.: 07951/302-0

TIx: 74372 scher of

Fax: 07951/26807

\section{France}

Schumacher

DMF S.A.

Z.1. 25. Rue Gay Lussac

B.P. 38

95502 Gonesse Cedex

Tél.: 1/39.85.93.14

Tix: 688018

Fax: 1/39.85.91.62
Japan

Nihon Schumacher

K.K.

Toyo Bidg. 12-20

Jingumae 6-Chome

Shibuya-Ku, Tokyo

Tel.: 81/3/34091531

TIx: 25561

Fax: B1/3/34861678
U.S.A

Schumacher

Filters America Inc.

P.O. Box 8040

Ashevilie

NC 28 814-8040.

Tel.: 704/252/9000

Fax: $704 / 253 / 7773$ 
Appendix C

Geologic Logs and Completion Diagrams for Piezometers at the Clean Test Site 


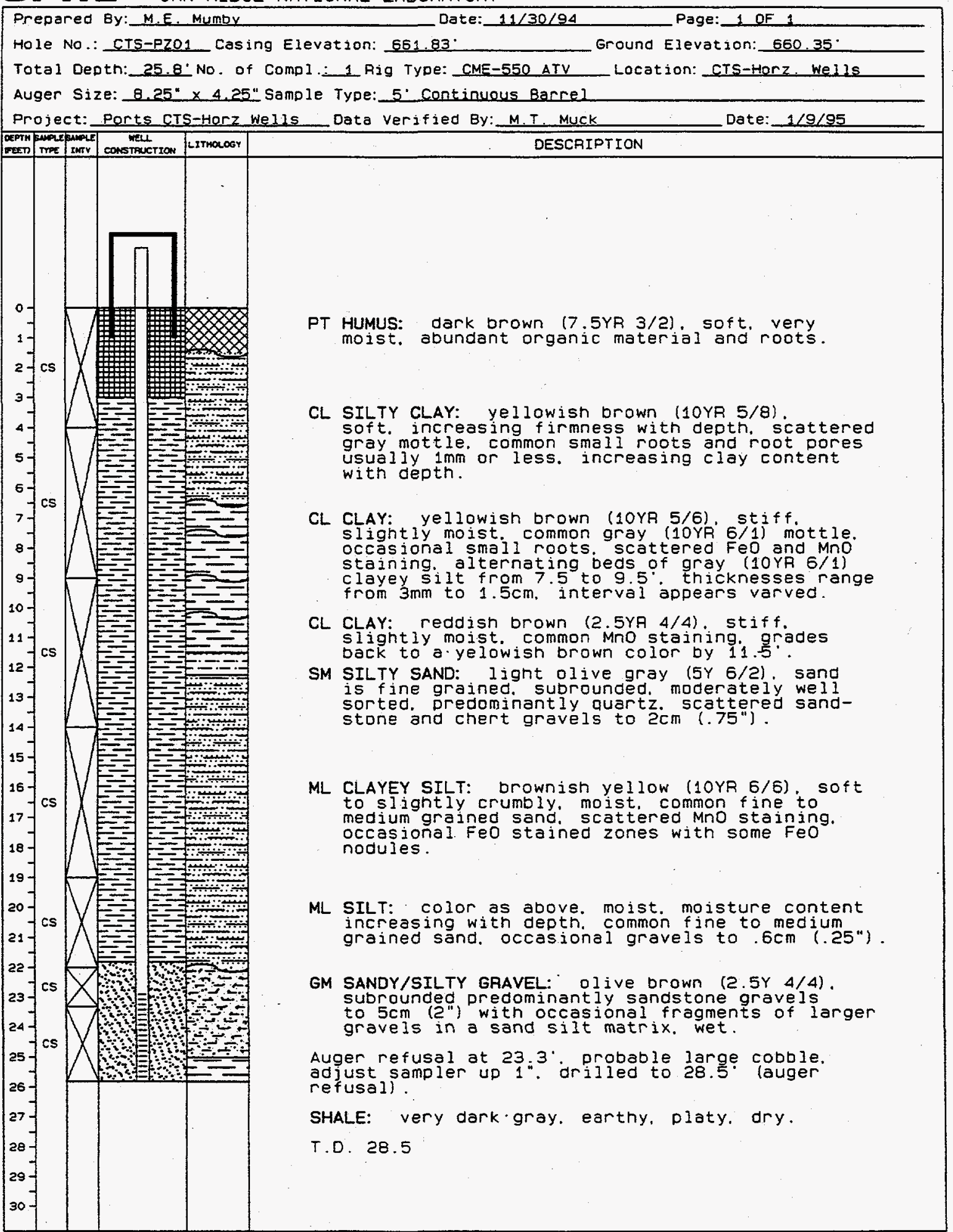


Well Summary Information

orn 1

OAK RIDGE NATIONAL LABORATORY

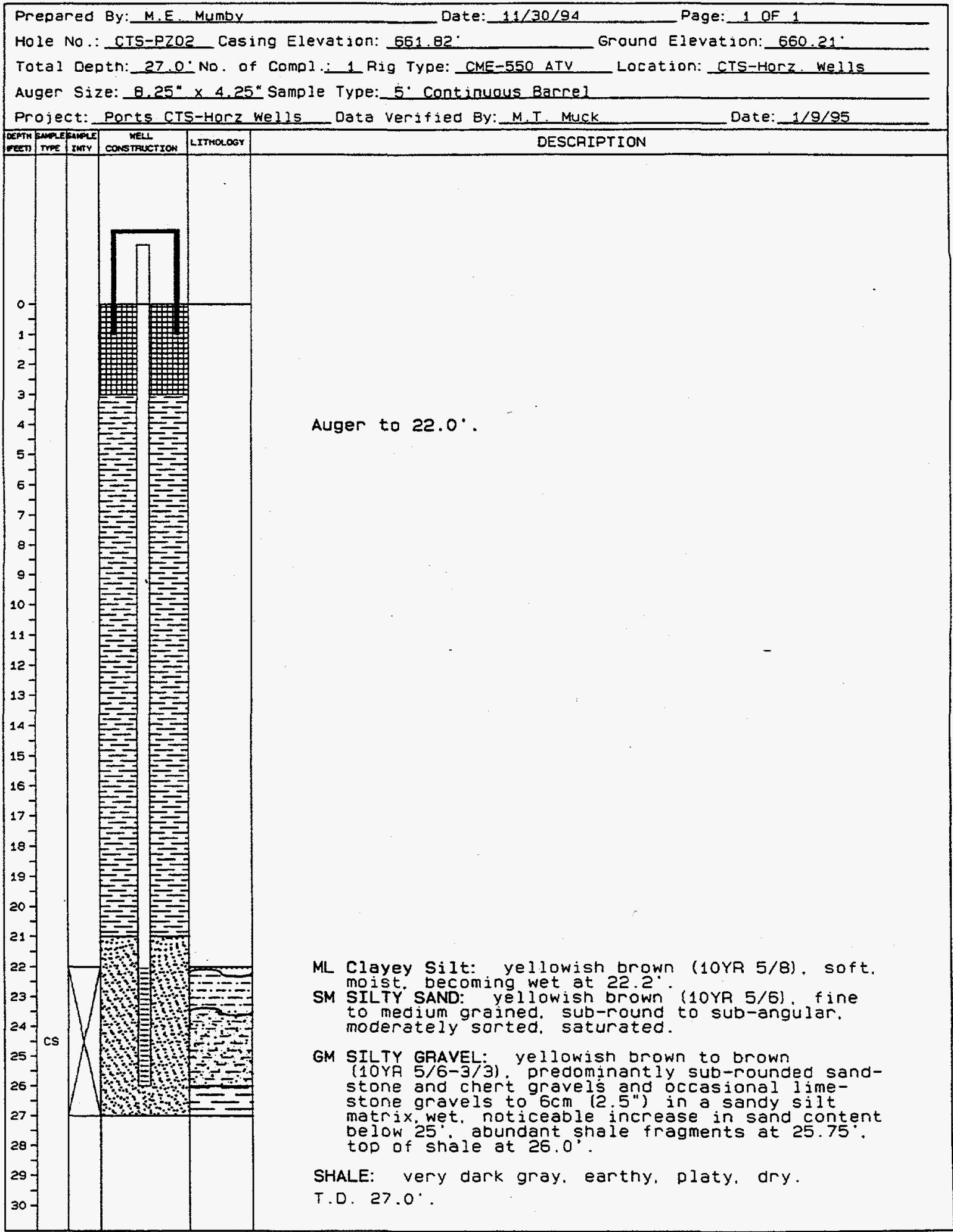


0TI OAK RIDGe national Laboratory

We 11 Summary Information

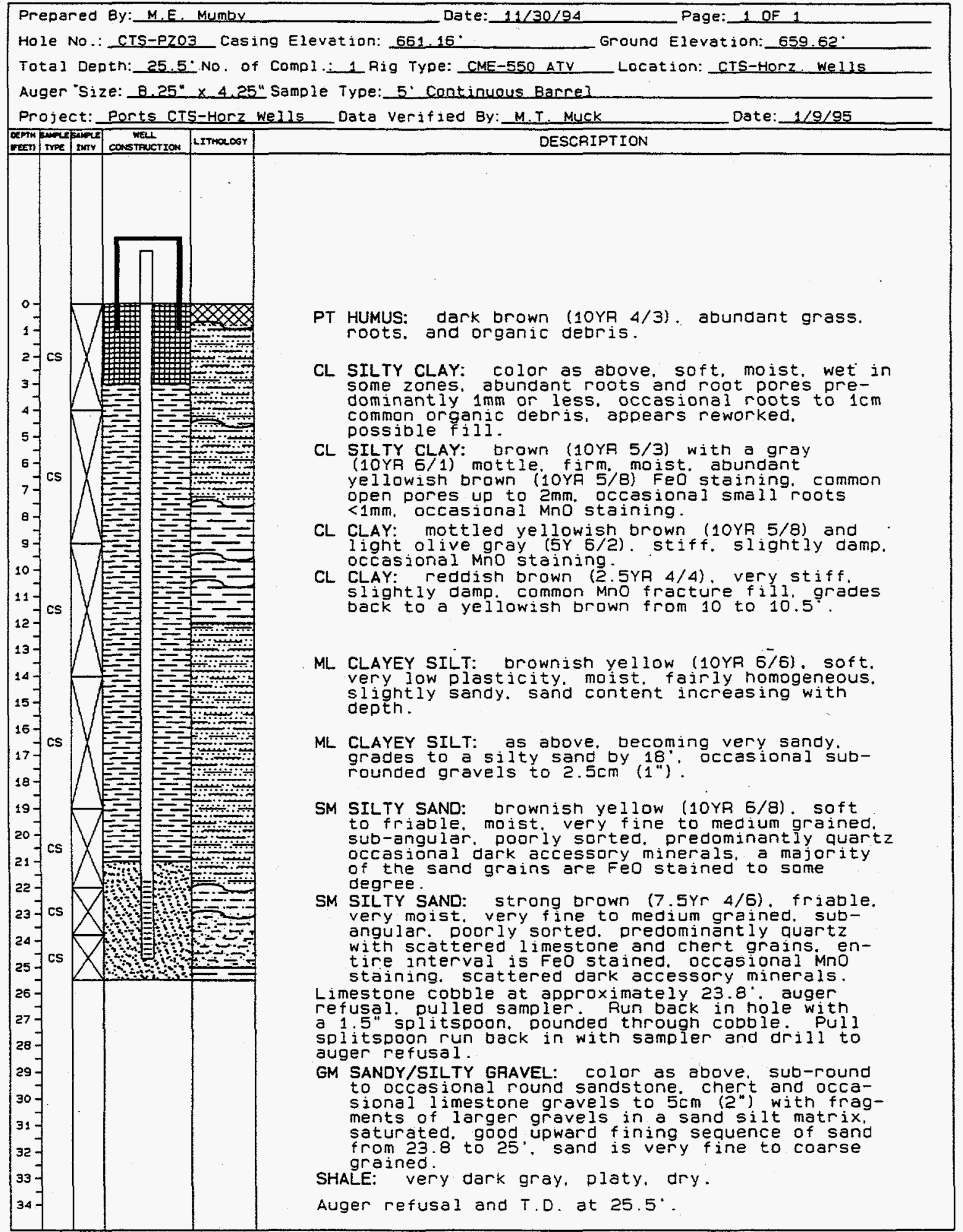


orn 1

Well Summary Information

OAK RIDGE NATIONAL LABORATORY

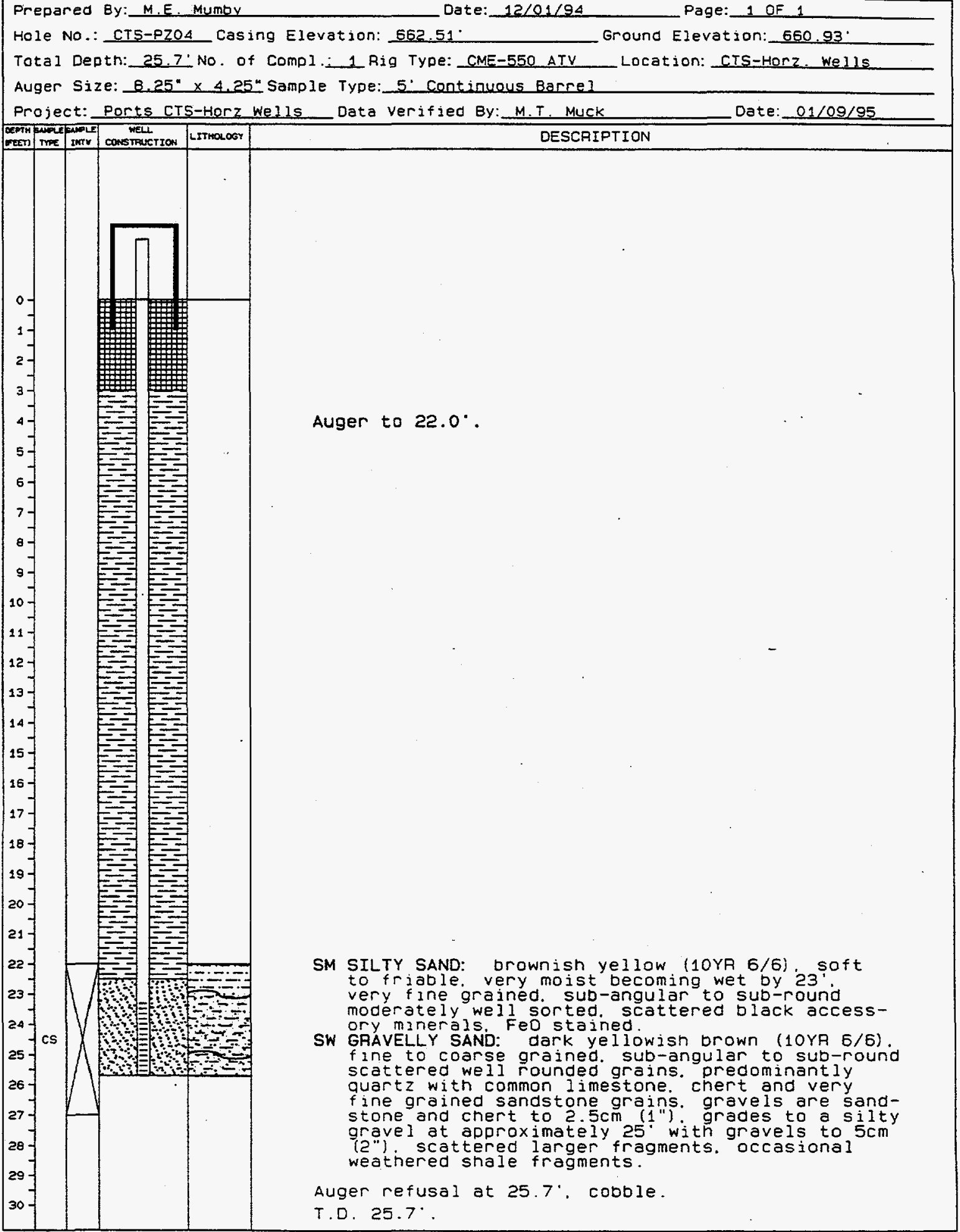


OTI OAK RIDGE national LABORATORY

We 11 Summary Information

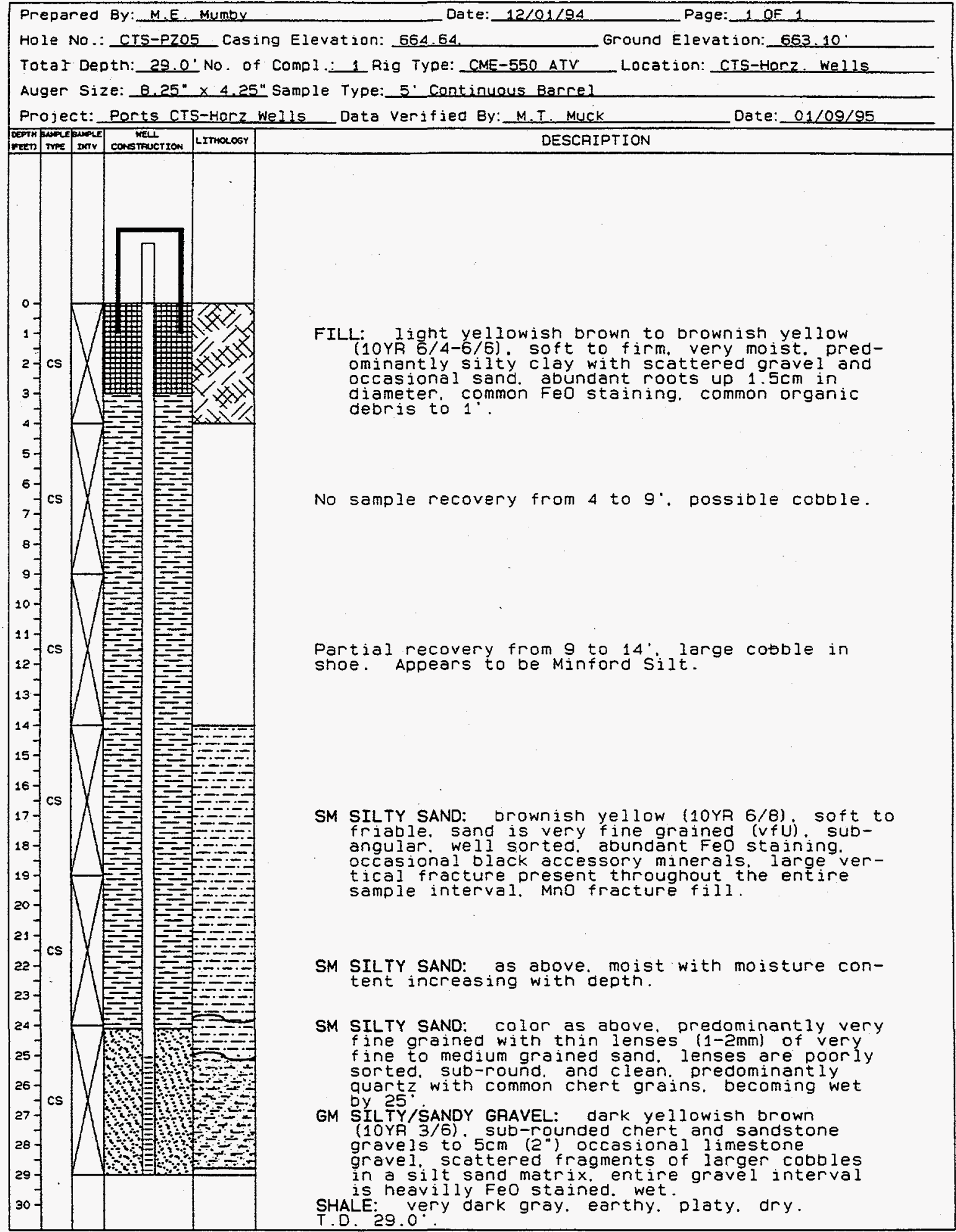




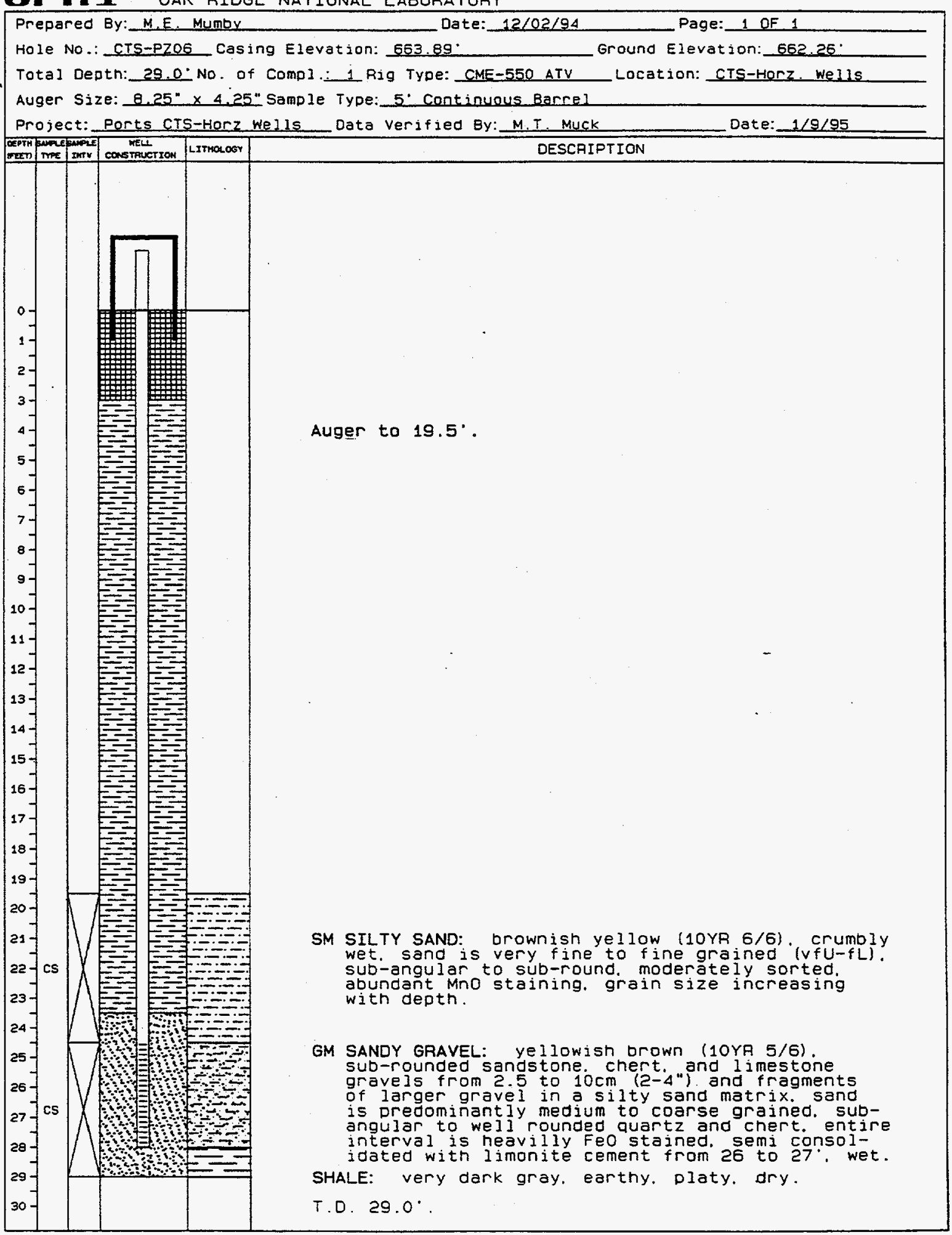


Well Summary Information

DIII OAK RIDGE national LABORATORY

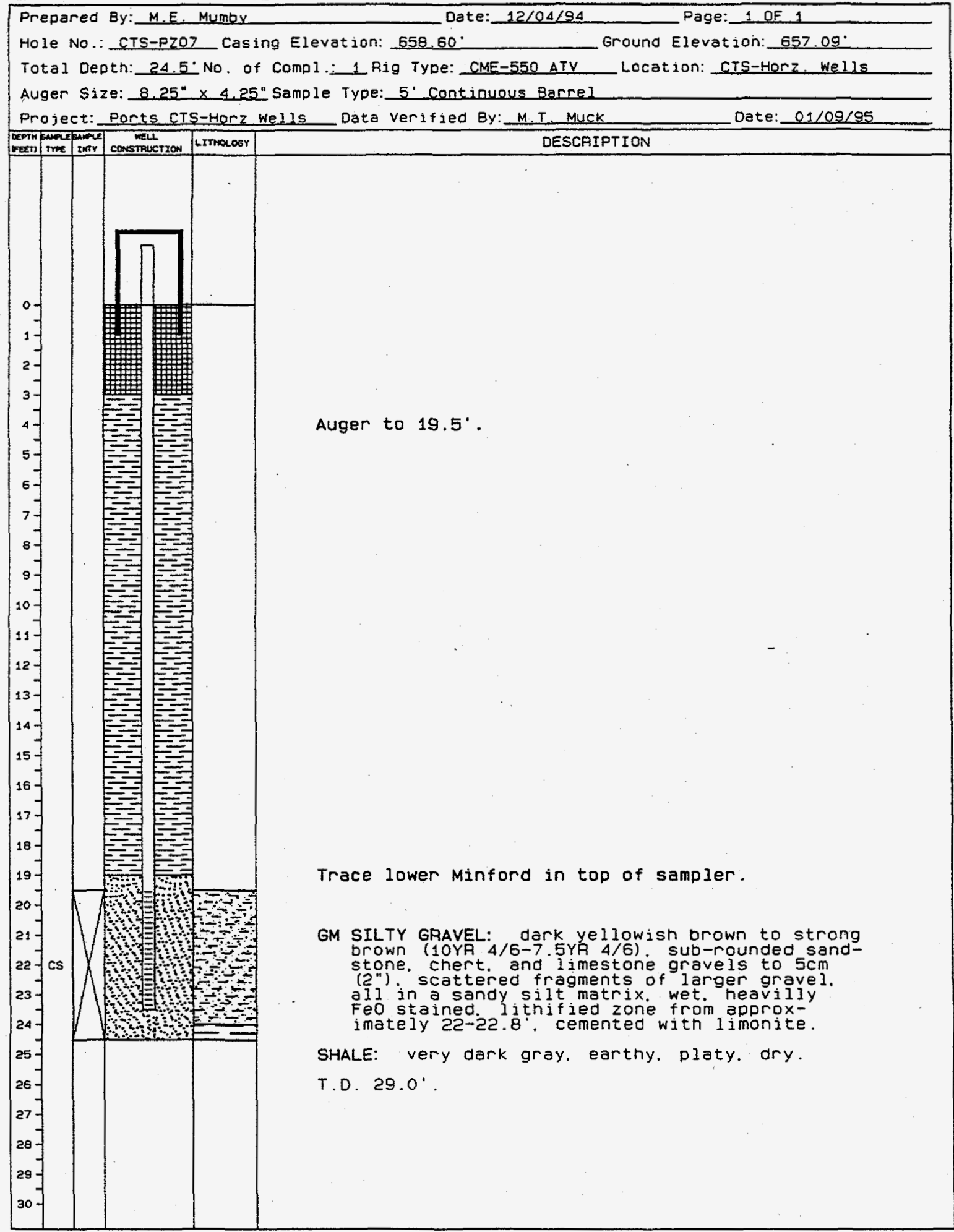


Well Summary Information

$\operatorname{orn} 1$

OAK RIDGE NATIONAL LABORATORY

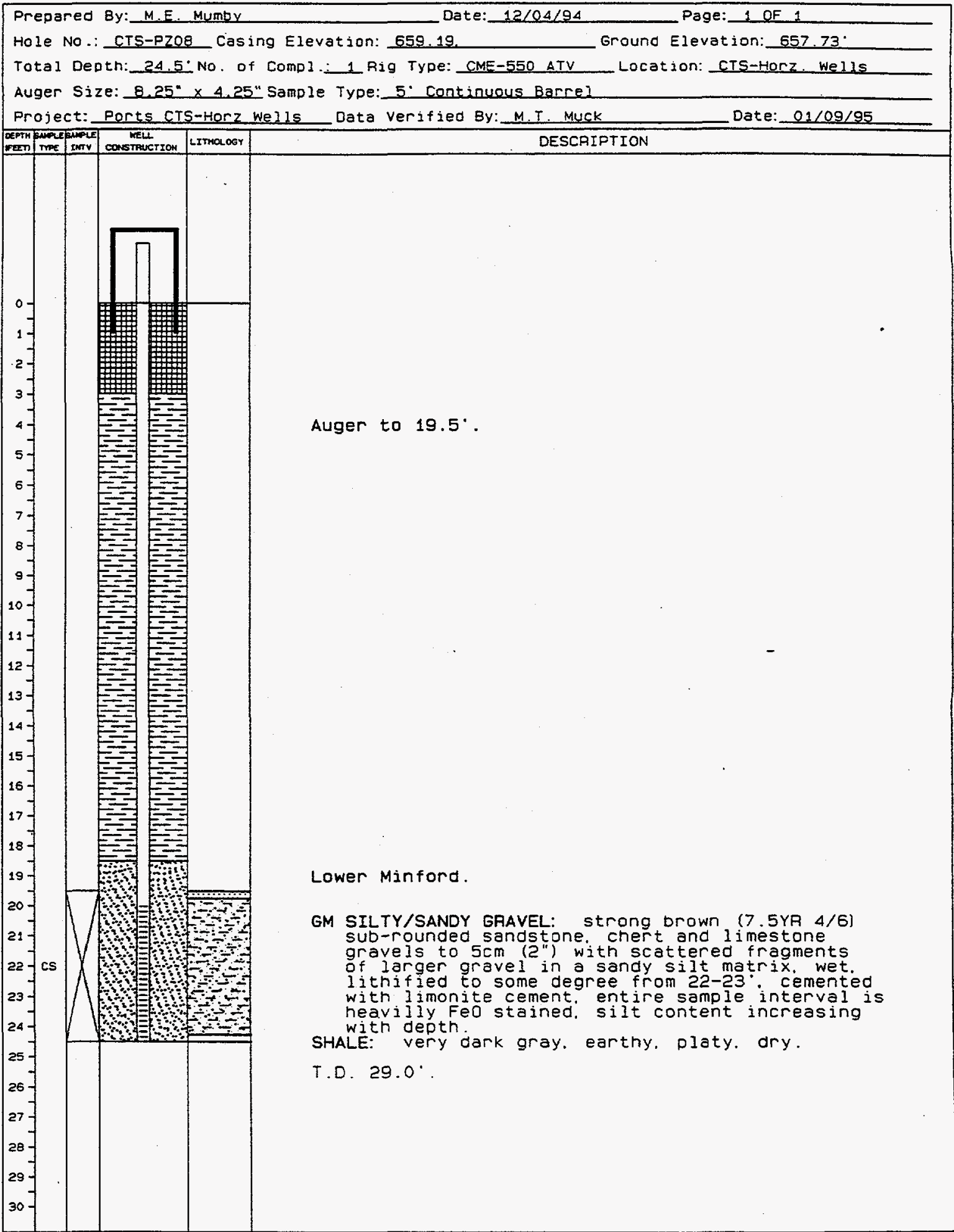




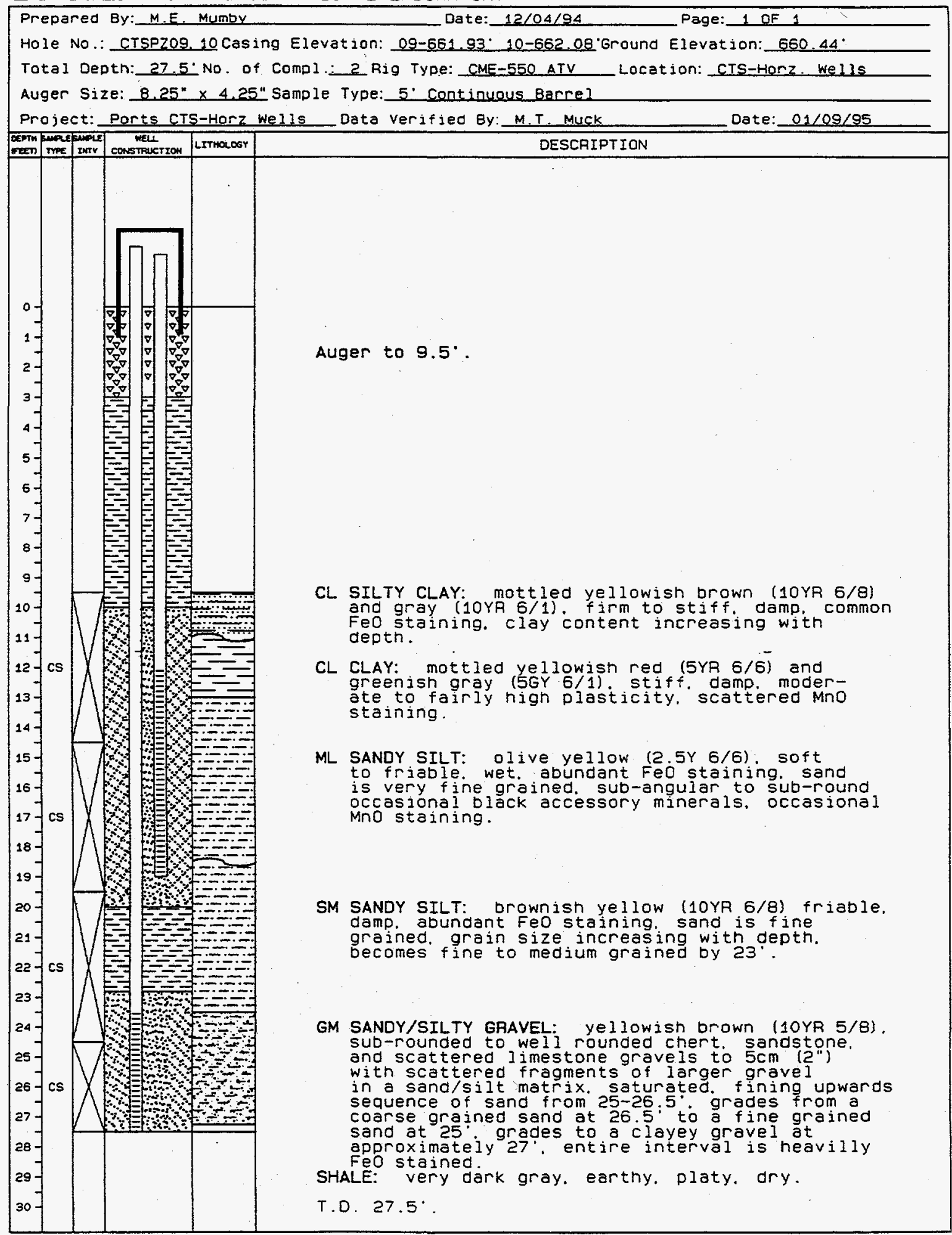




\section{$\operatorname{orn} 1$}

We I 1 Summary Information

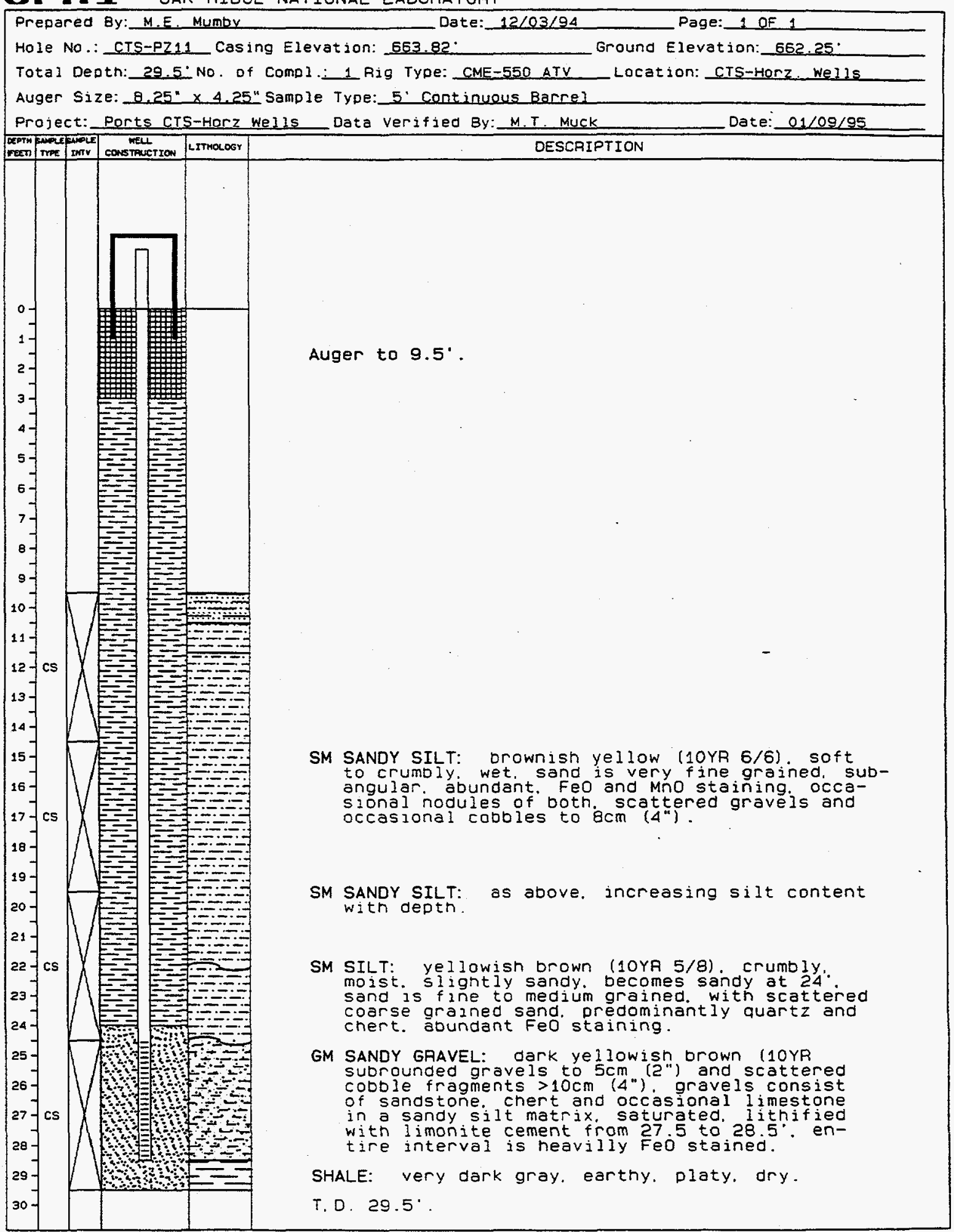


We I I Summary Information

OIn 1 oak ridge national Laboratory

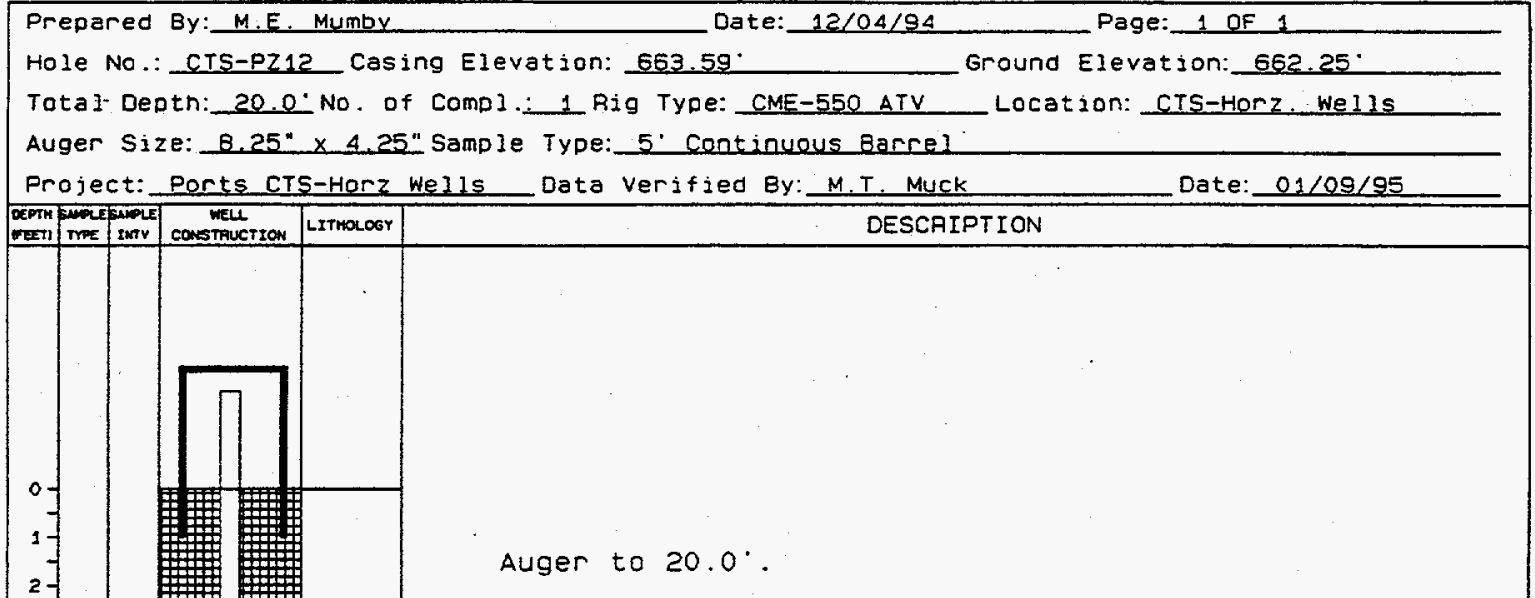

T. D. $20.0^{\circ}$. 


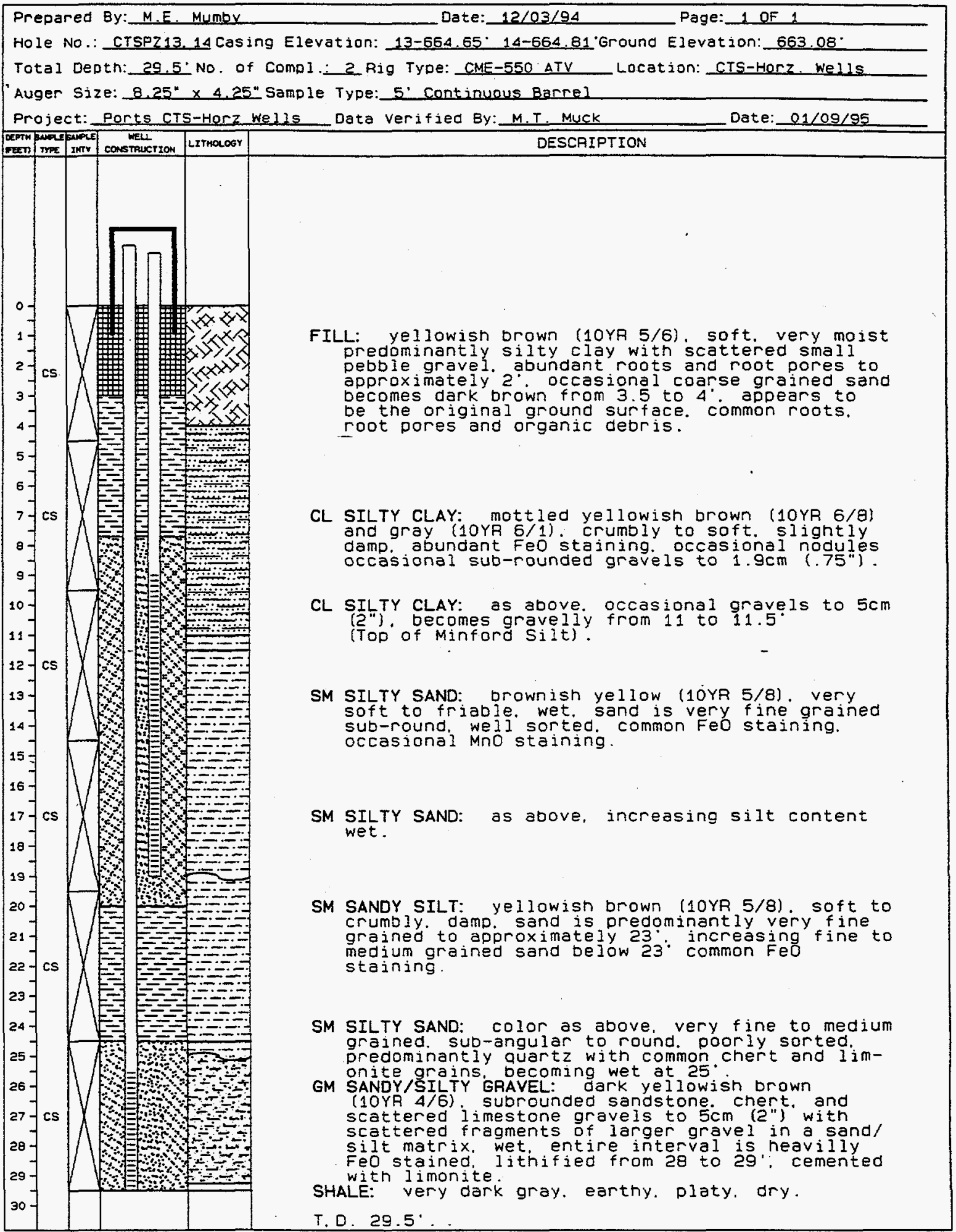




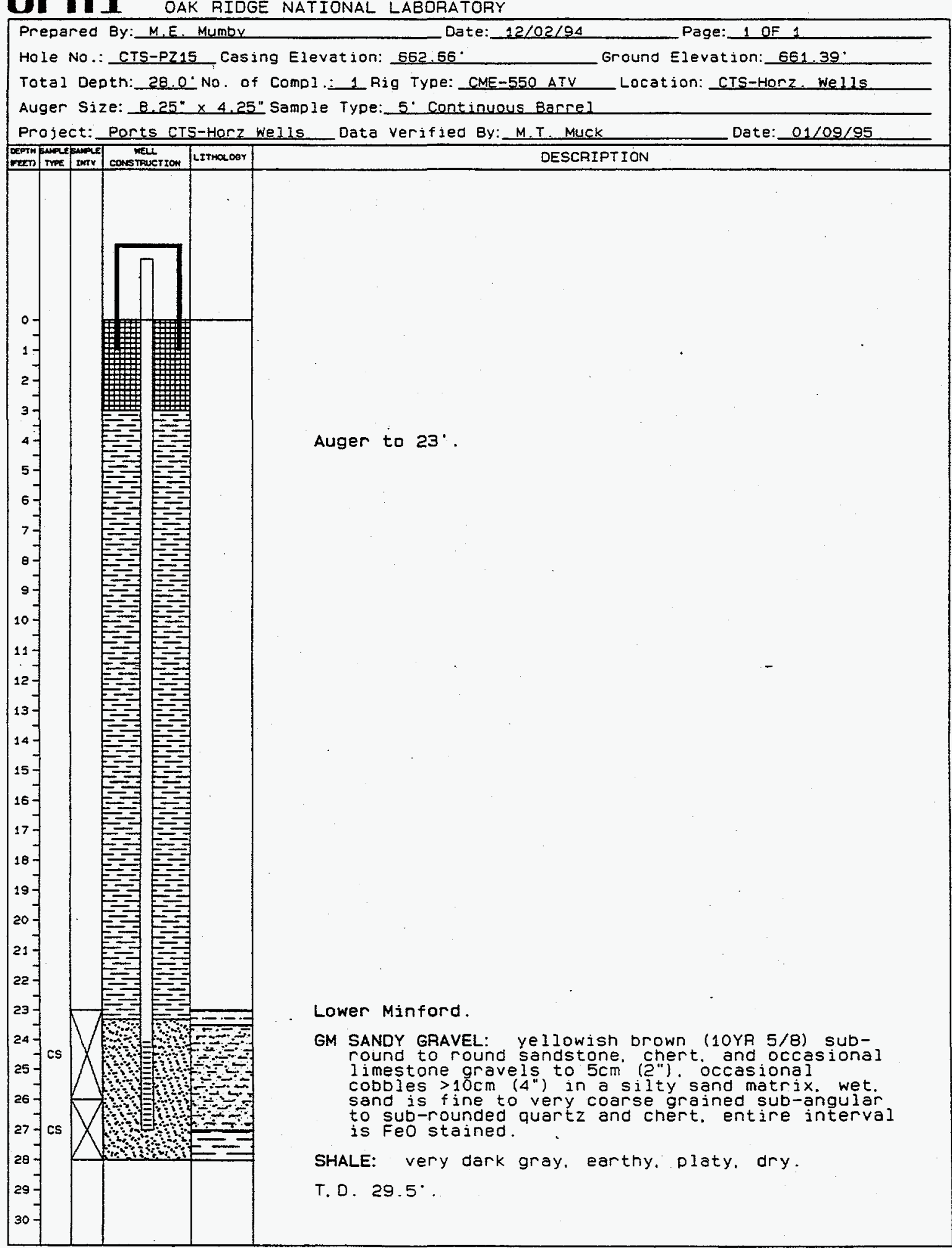




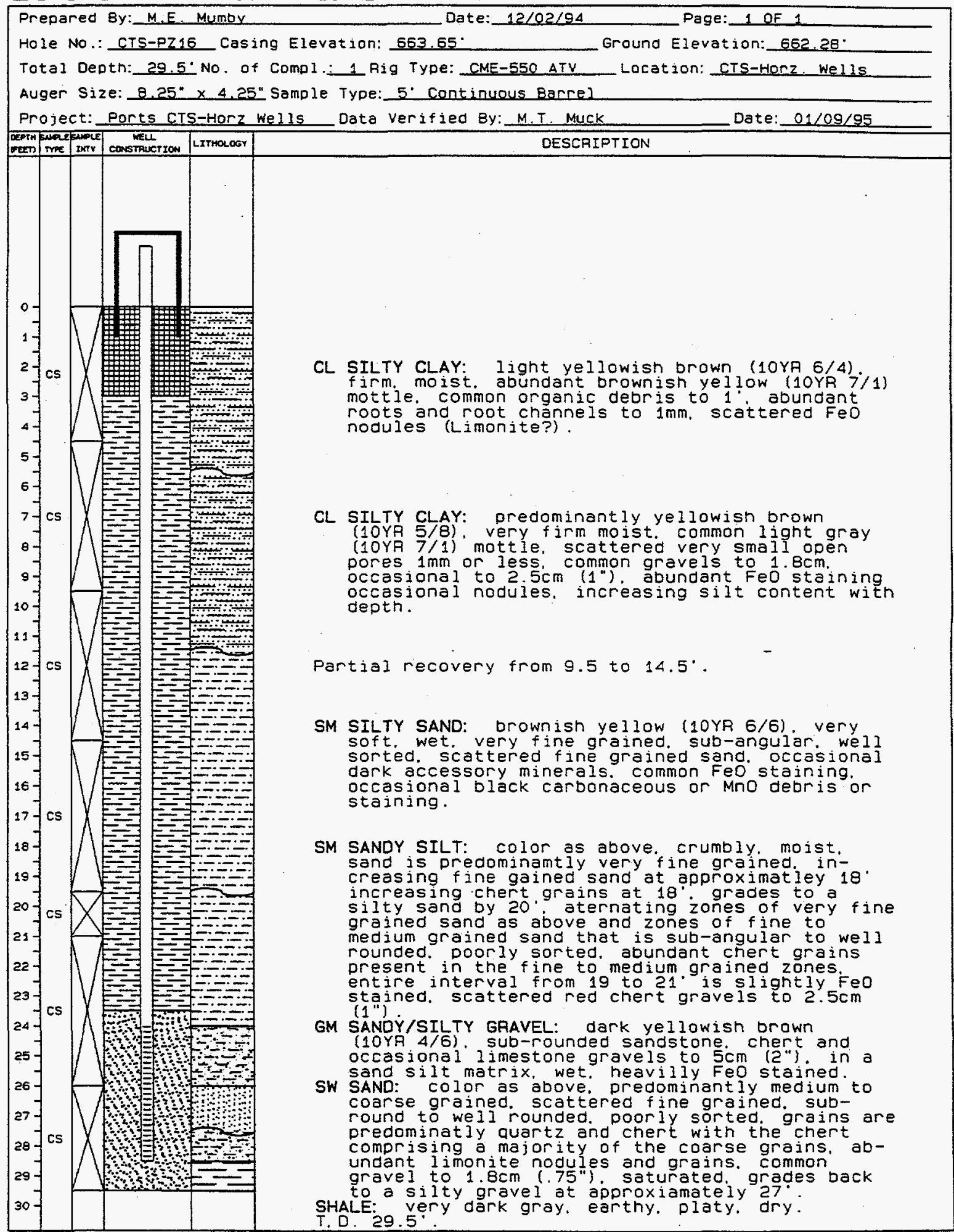


Well Summary Information

0II] OAK RIDGE NATIONAL LABORATORY

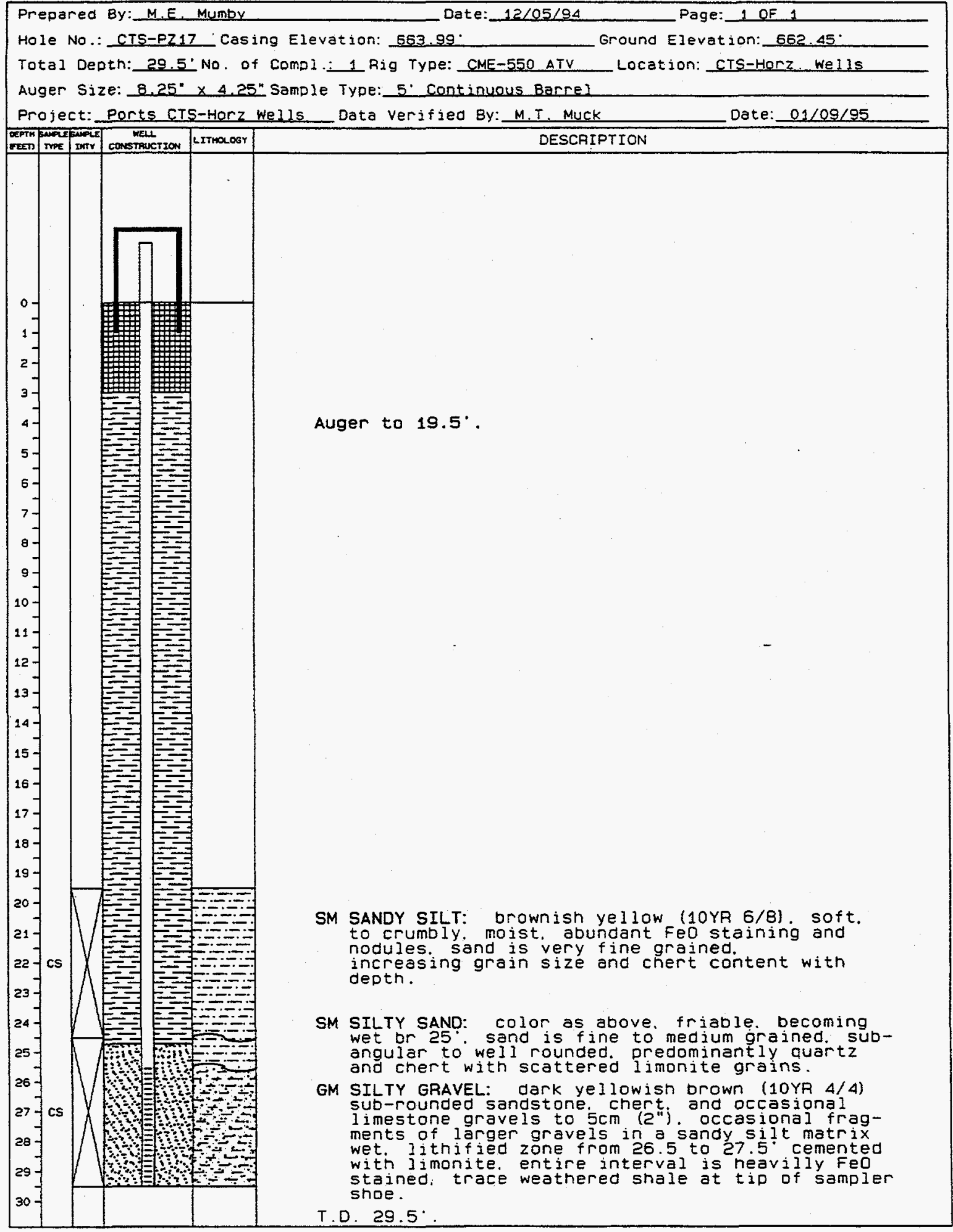


orn 1

Well Summary Information

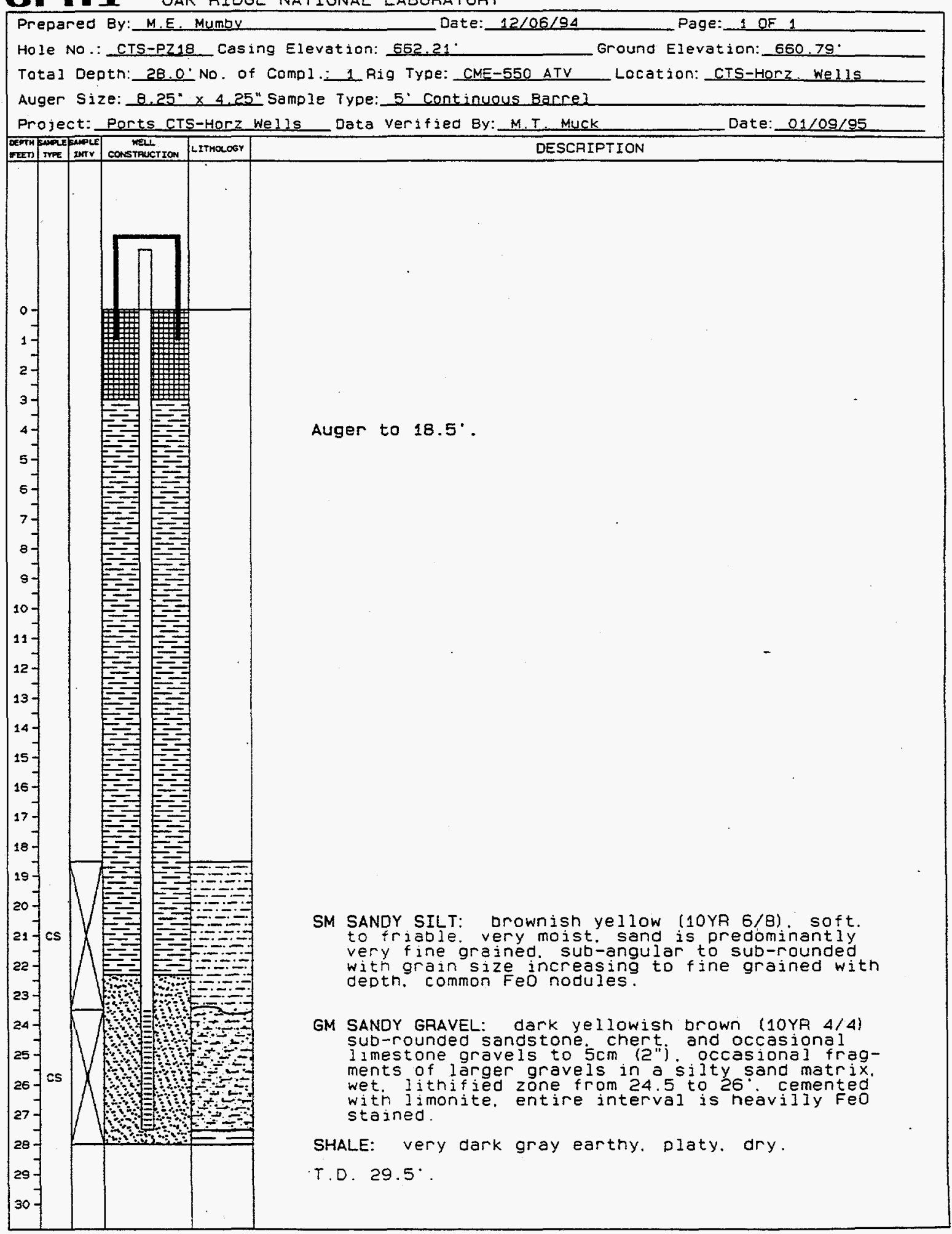


$\operatorname{orn} 1$

We 11 Summary Information

OAK RIDGE NATIONAL LABDRATORY

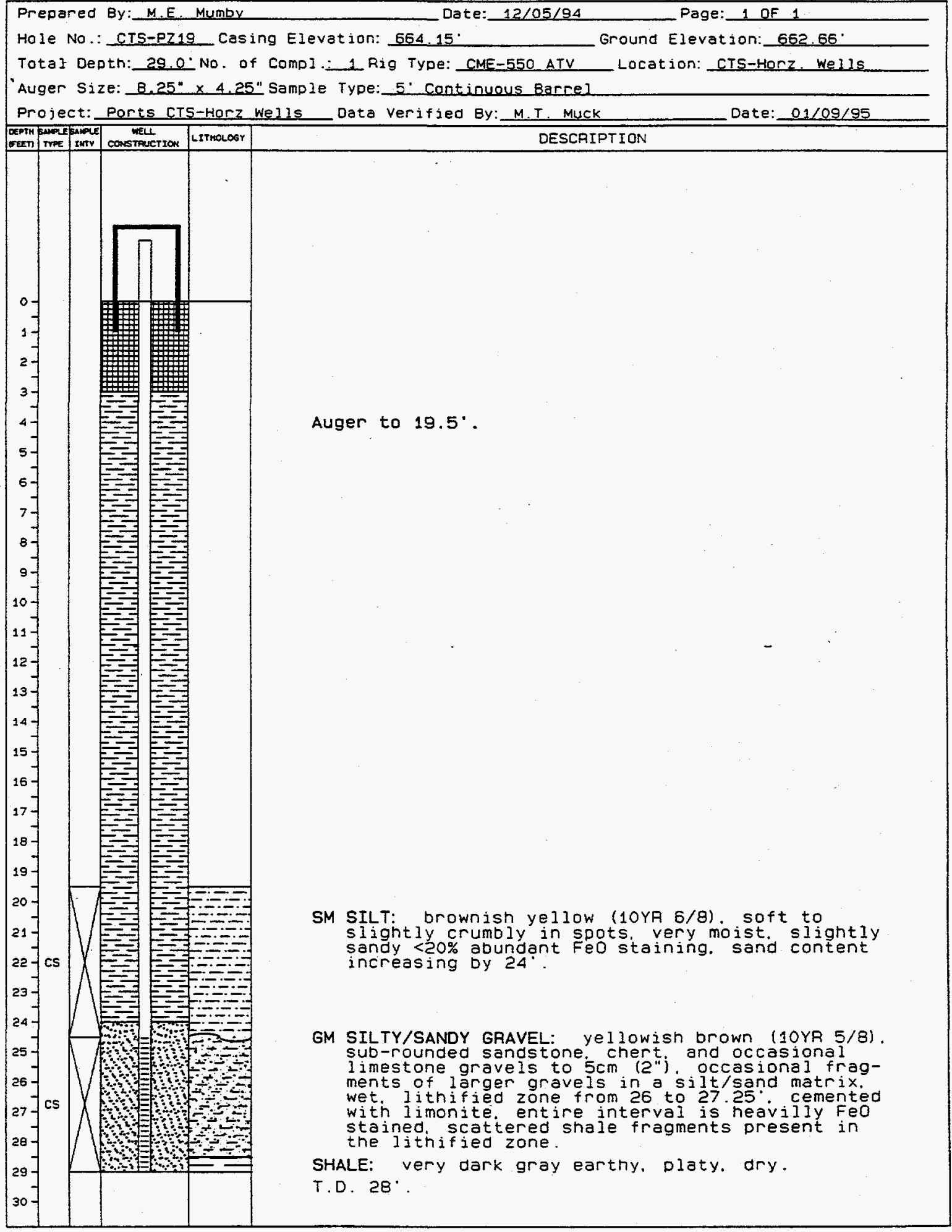


We 11 Summary Information

0II OAK RIDGE NATIONAL LABORATORY

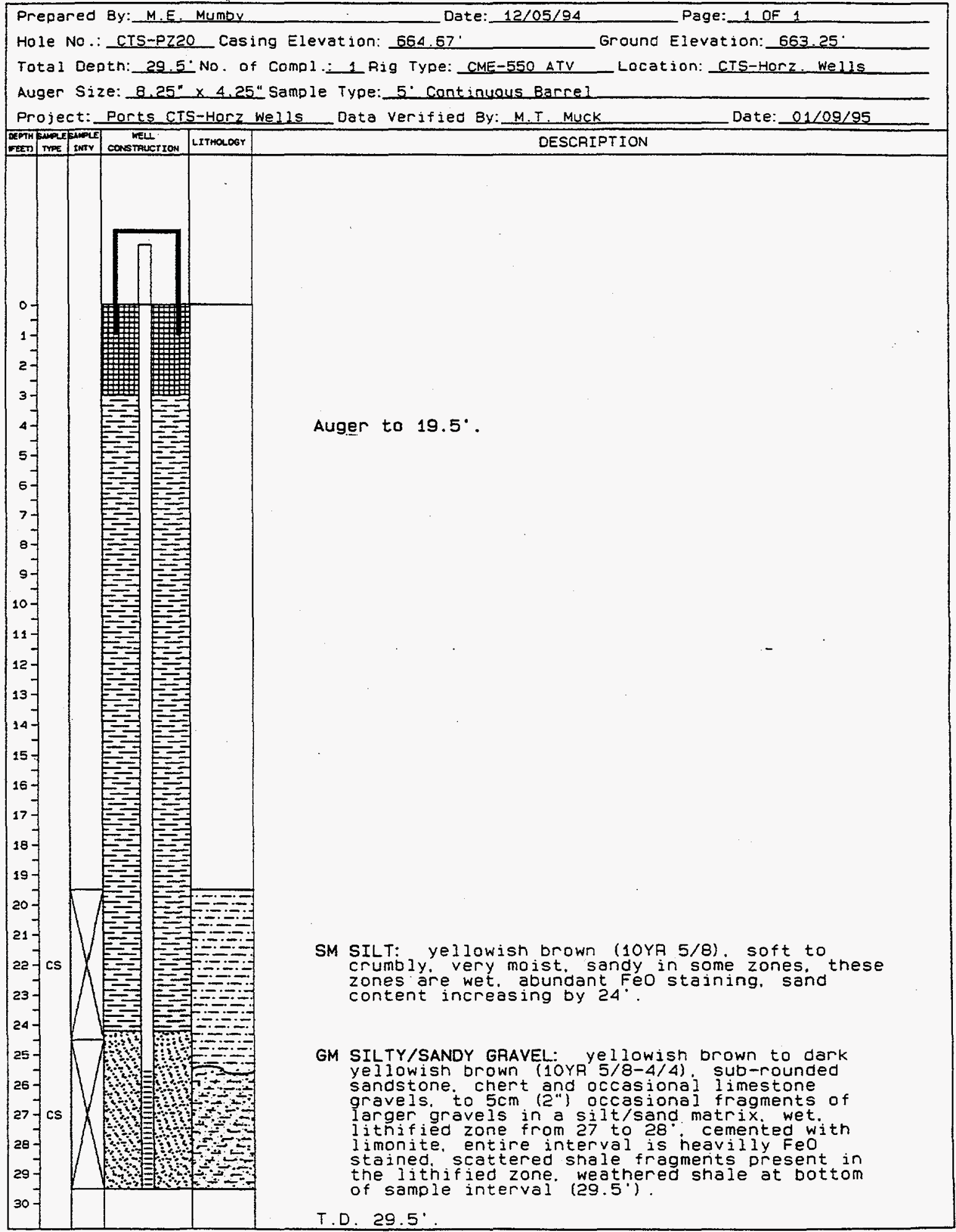


Well Summary Information

orn 1

OAK RIDGE NATIONAL LABORATORY

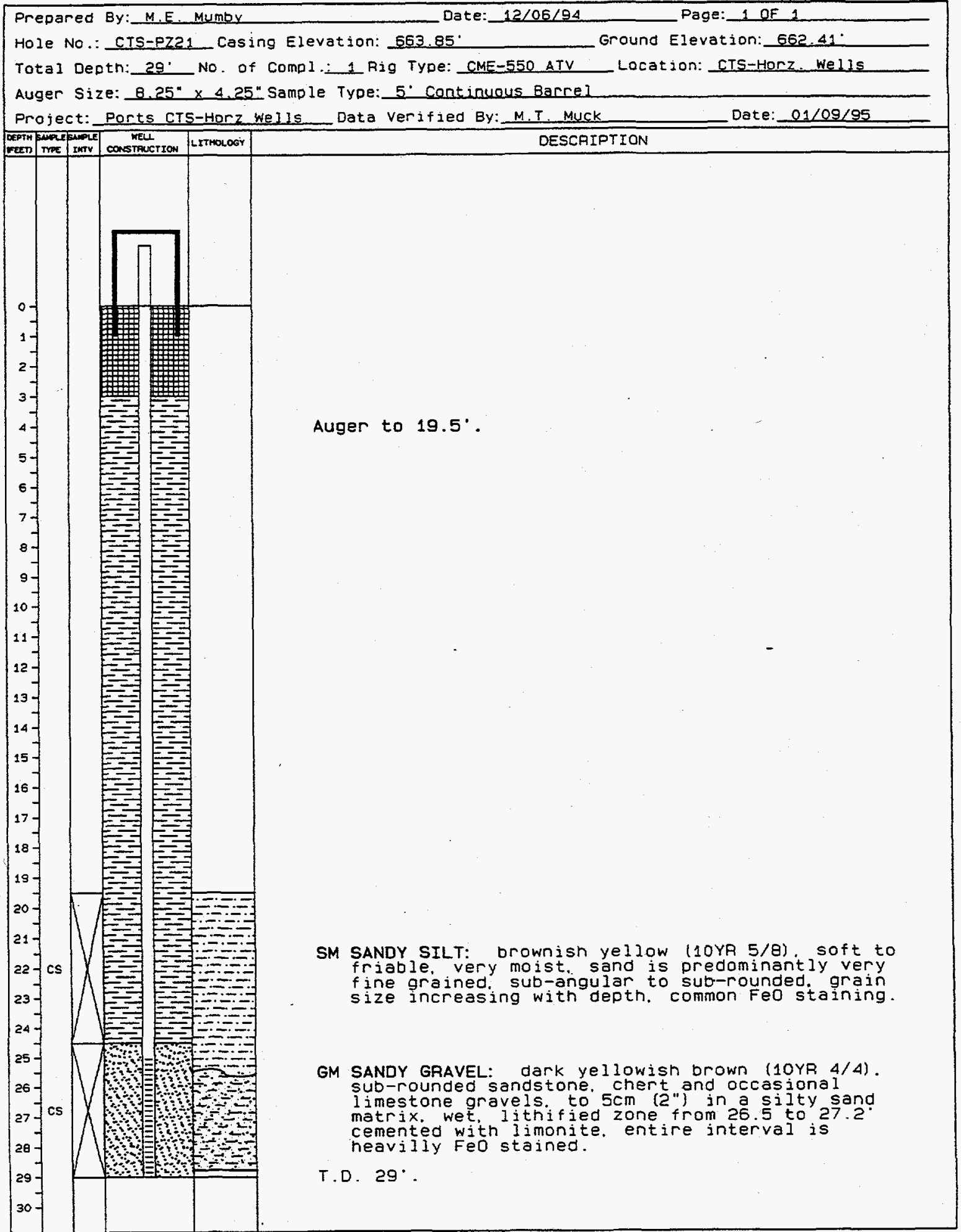


orn 1

We 11 Summary Information

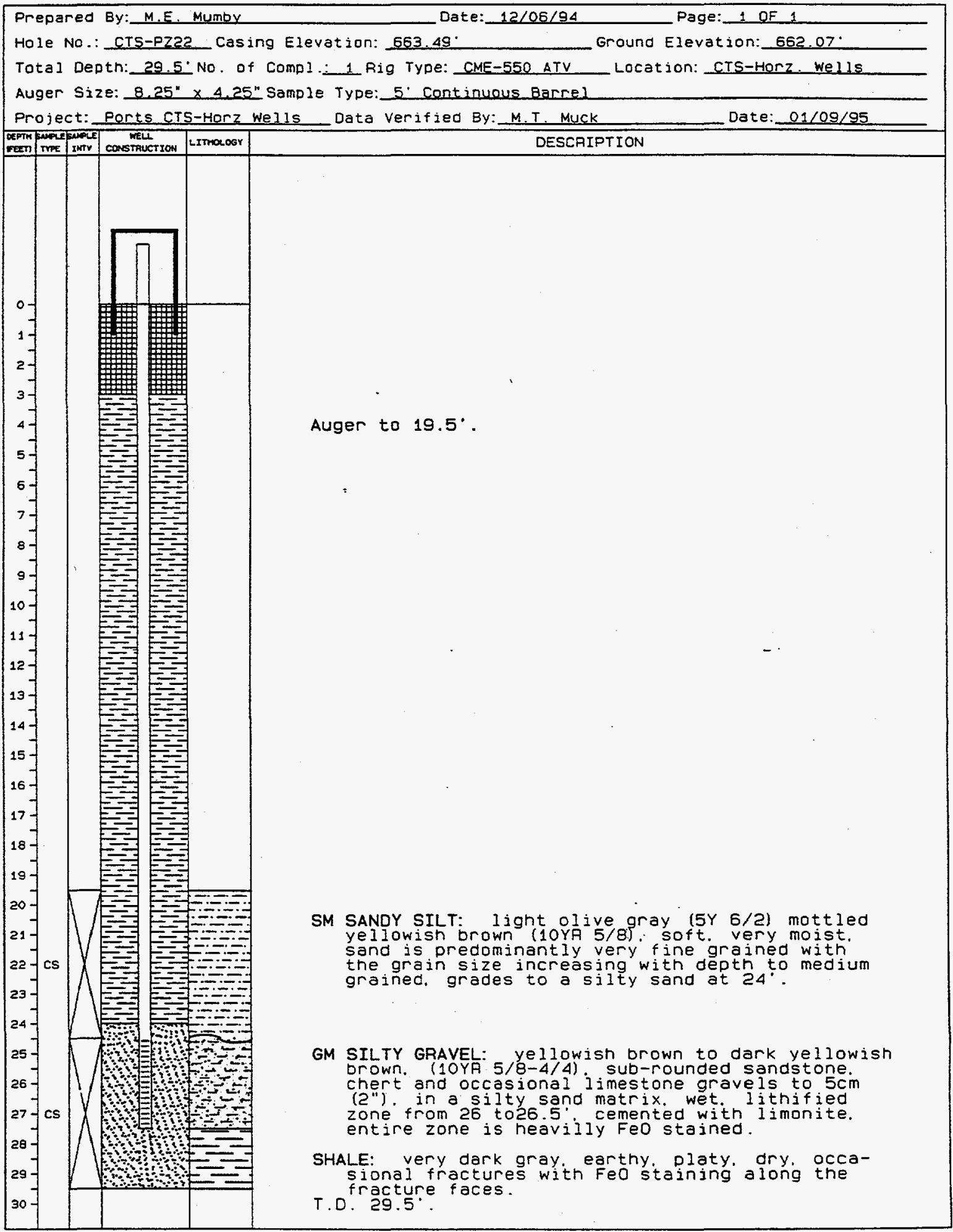


Piezometer Summary Information

UII Dak Ridge national Laboratory

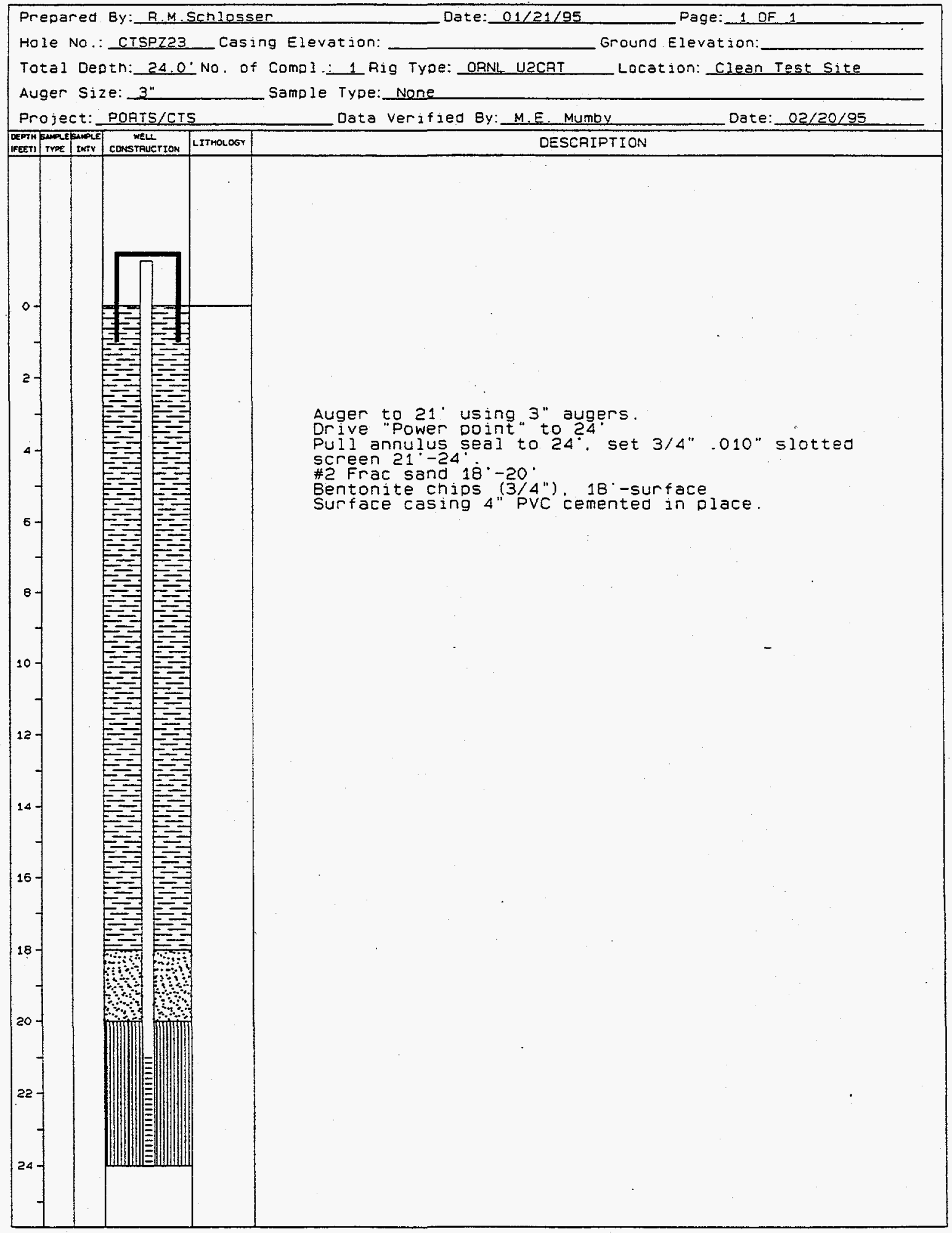


orn 1

Piezometer Summary Information

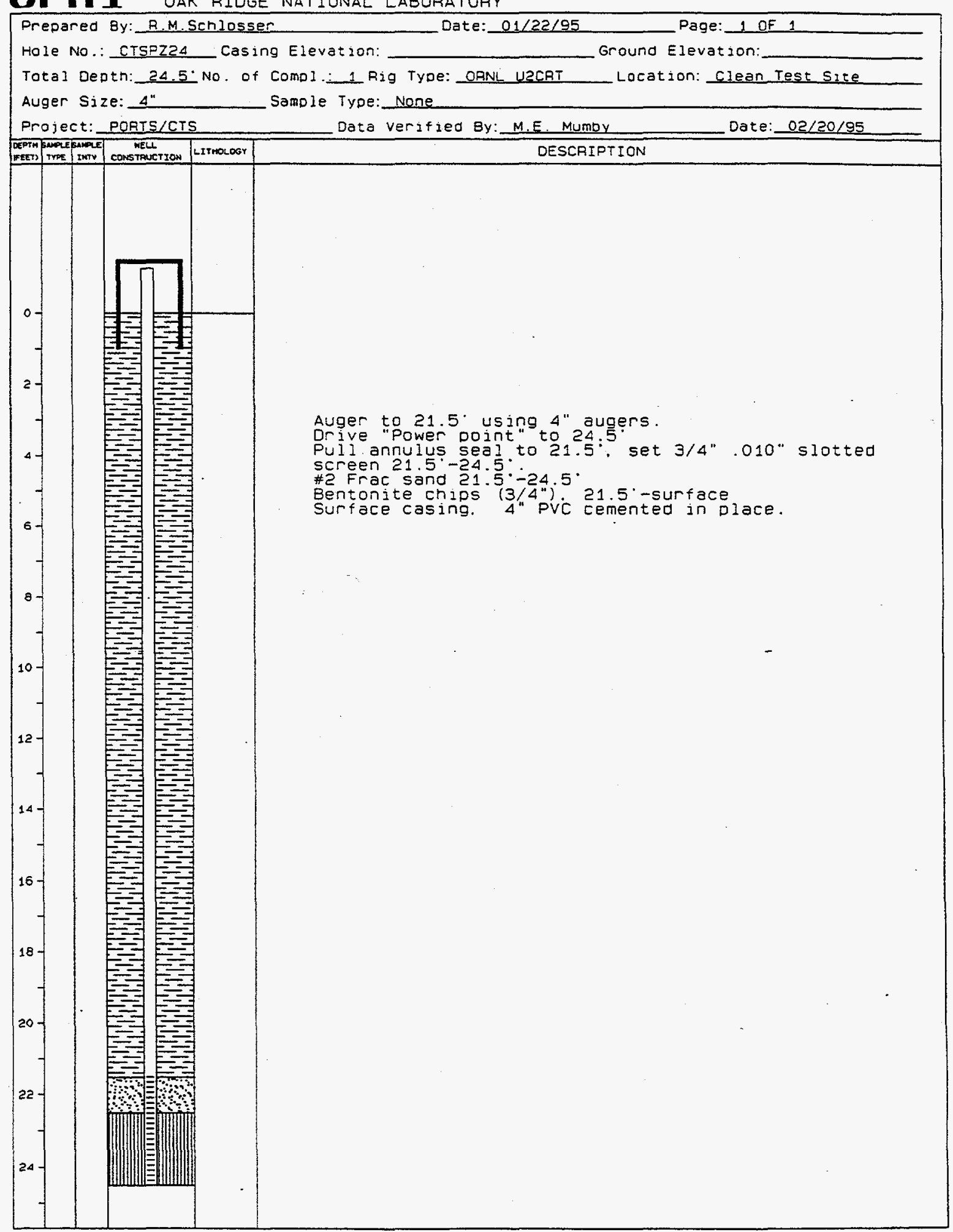


Piezometer Summary Information

UII OAK RIDGE NATIONAL LABORATORY

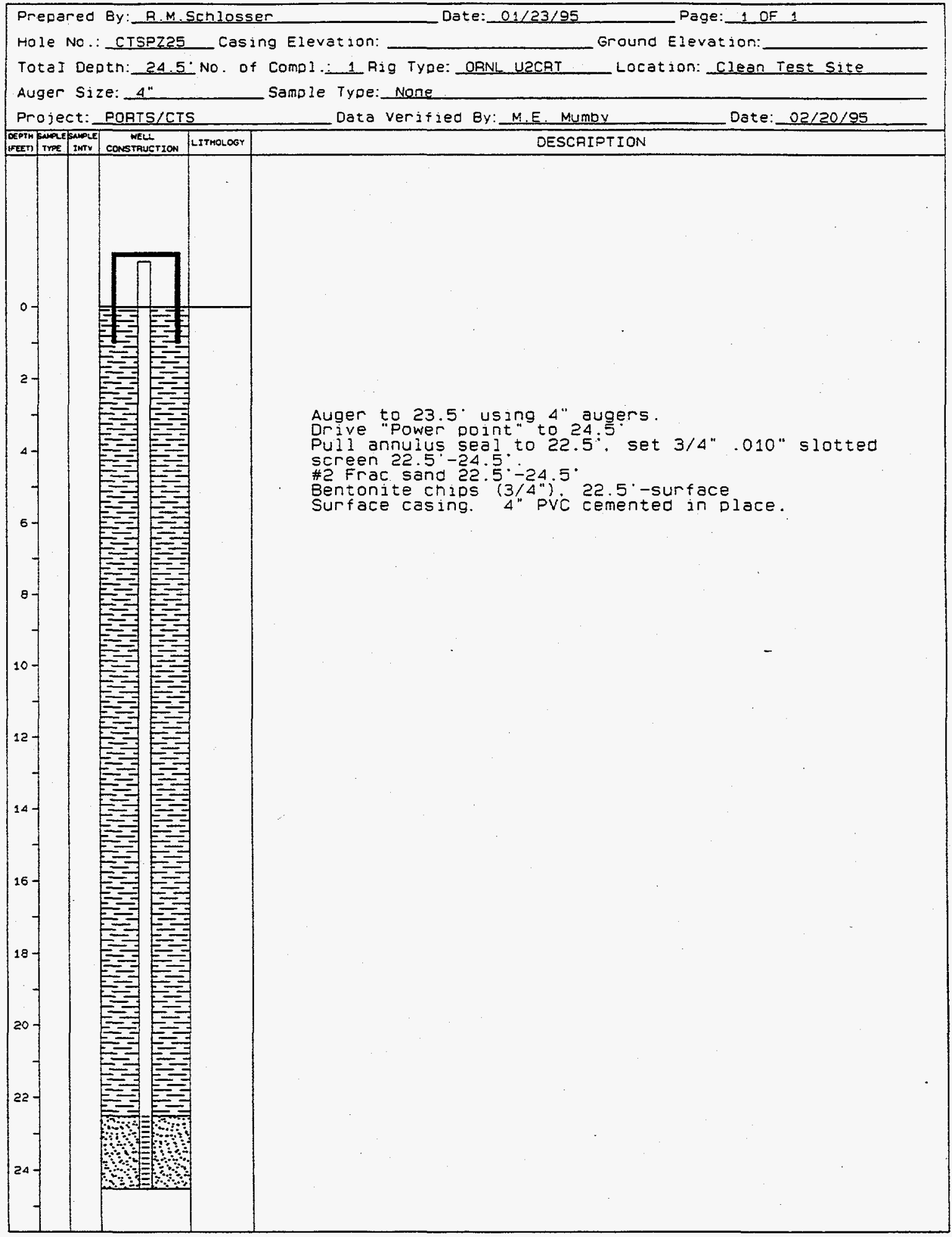


arn 1 Piezometer Summary Information

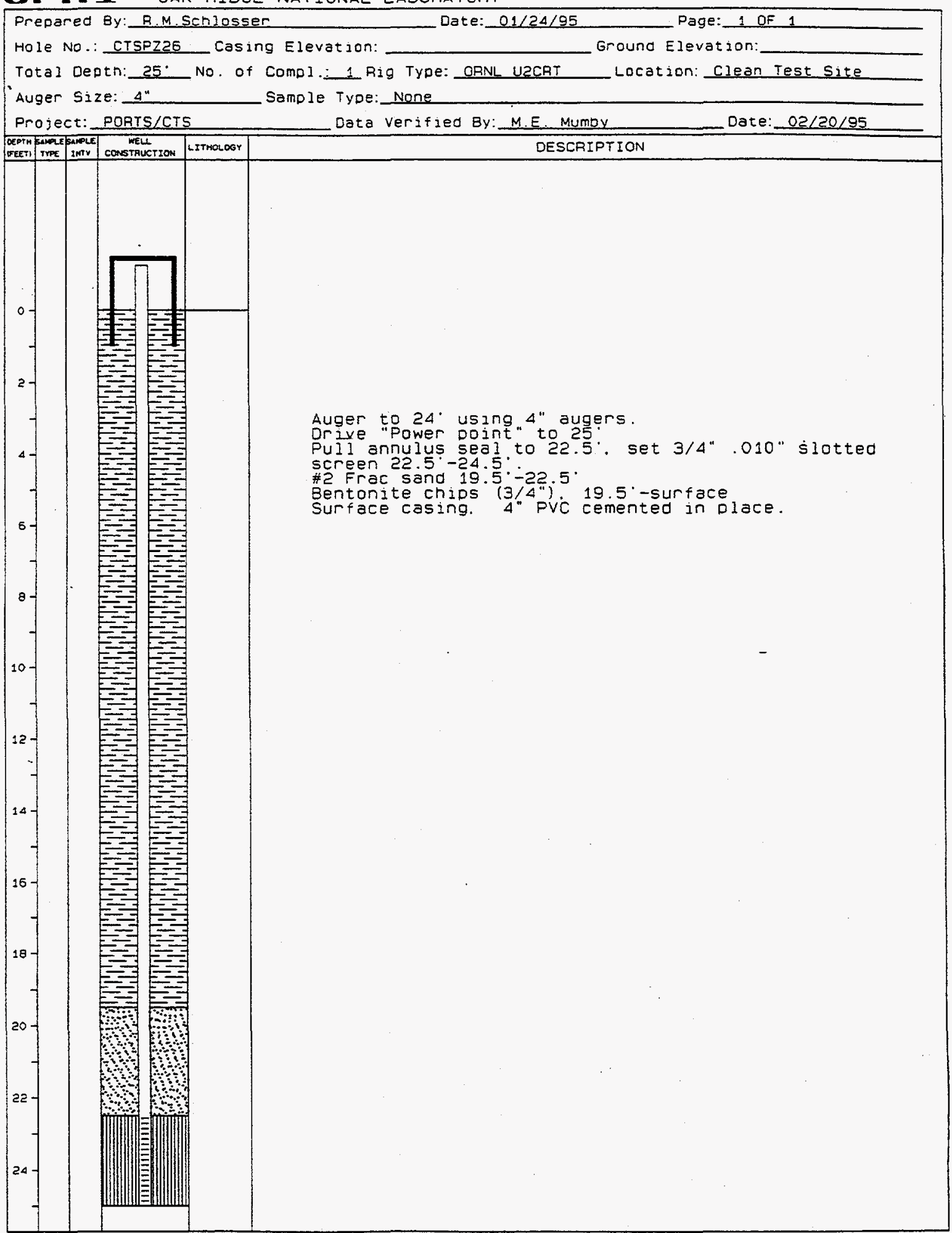




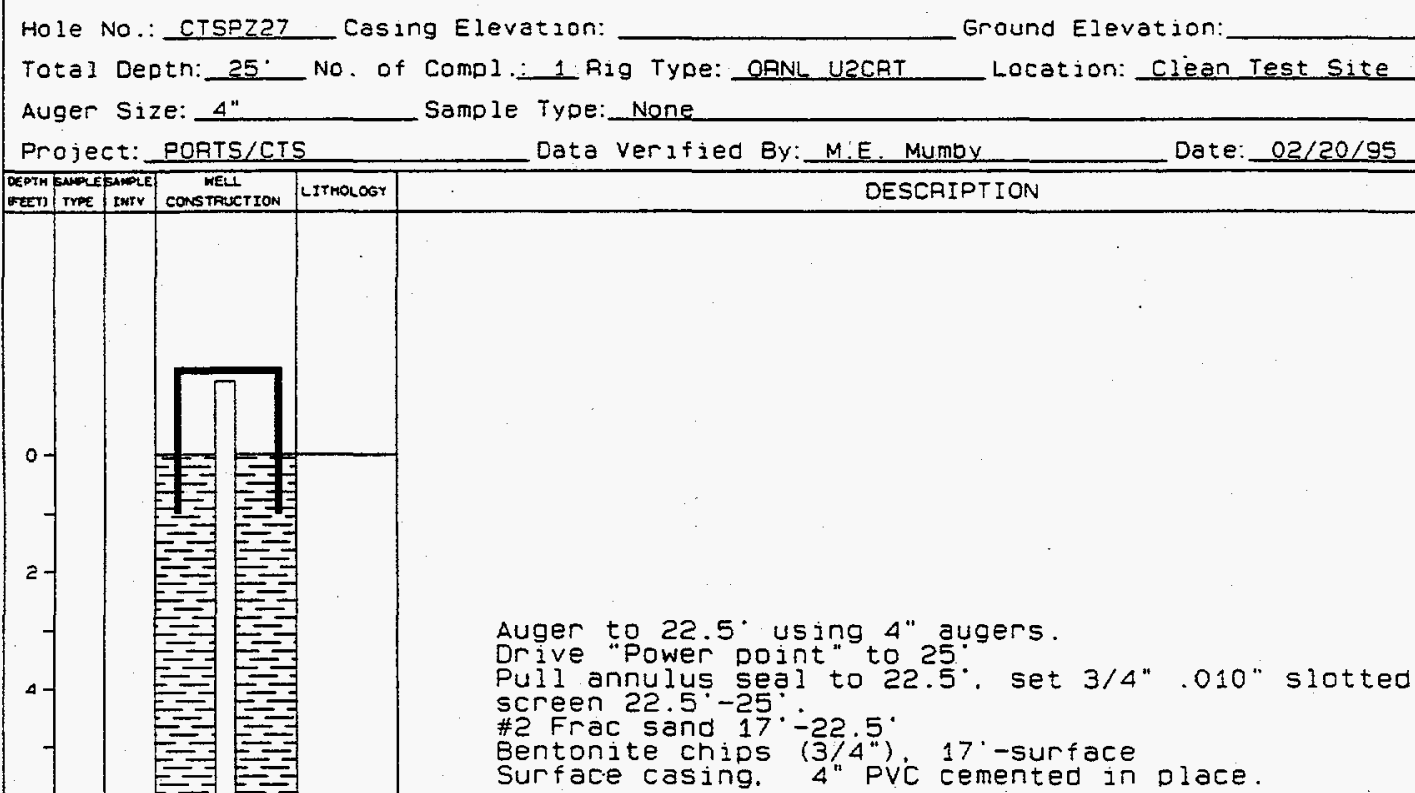


orn 1

Piezometer Summary Information

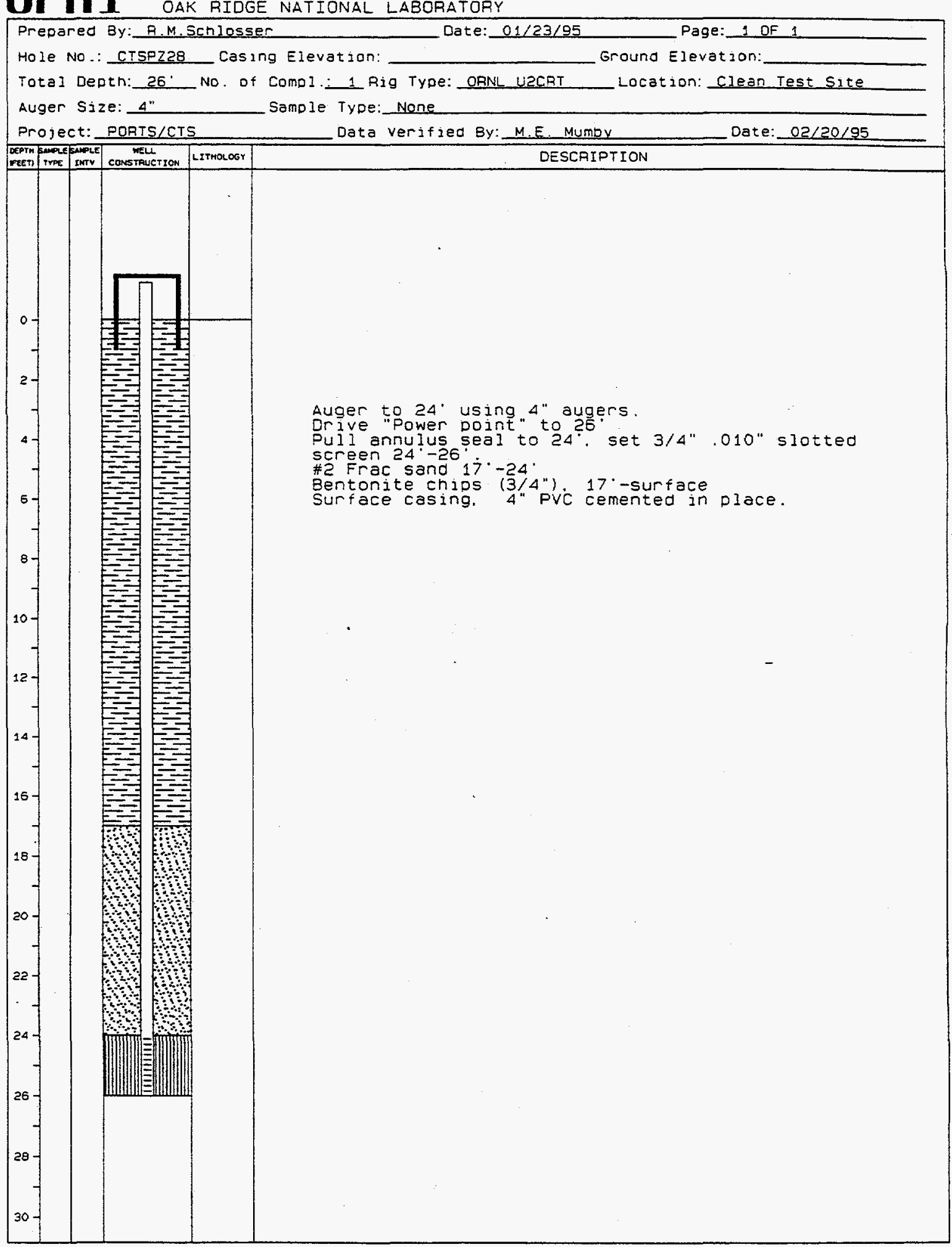


DT Piezometer Summary Information

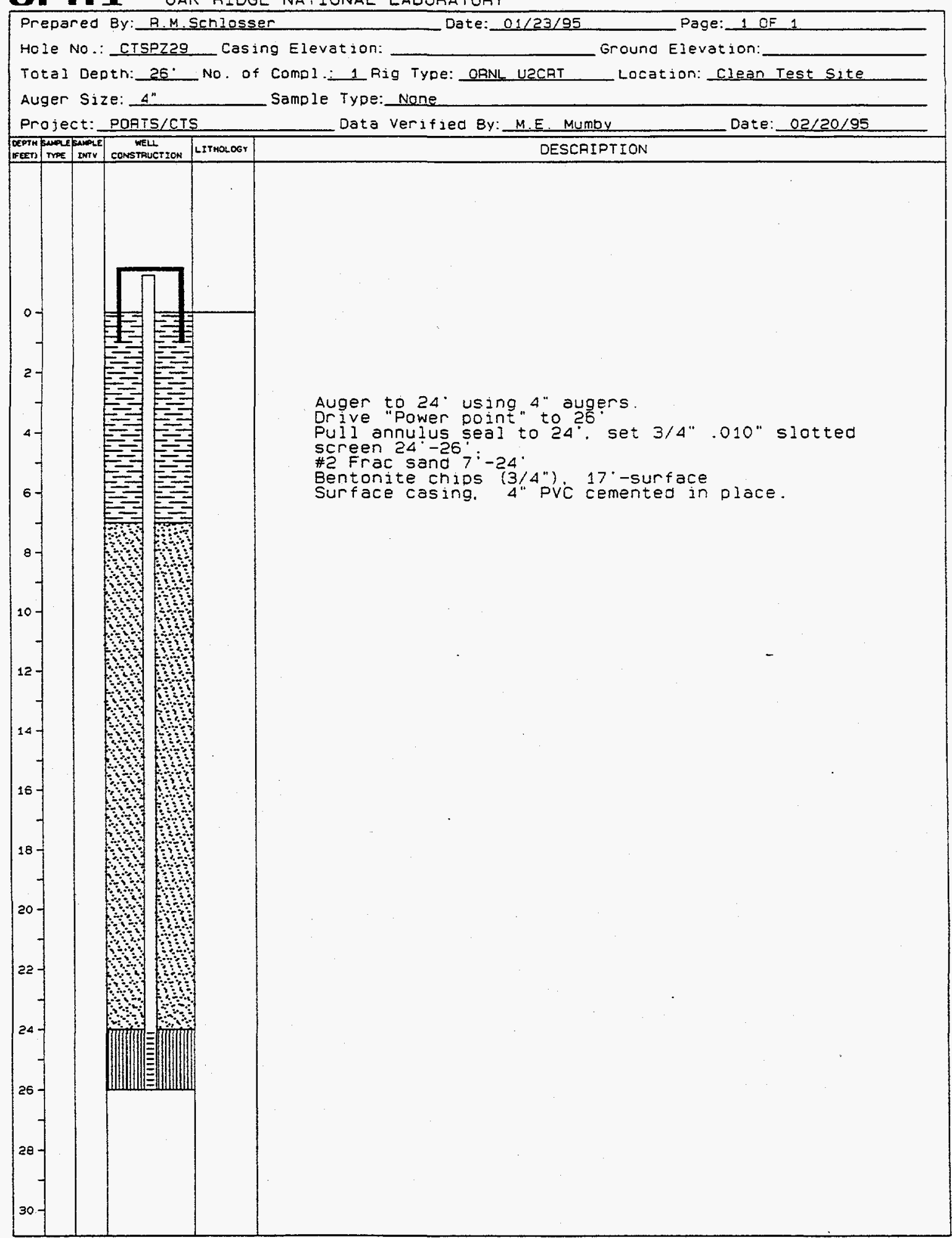


orn 1

Piezometer Summary Information

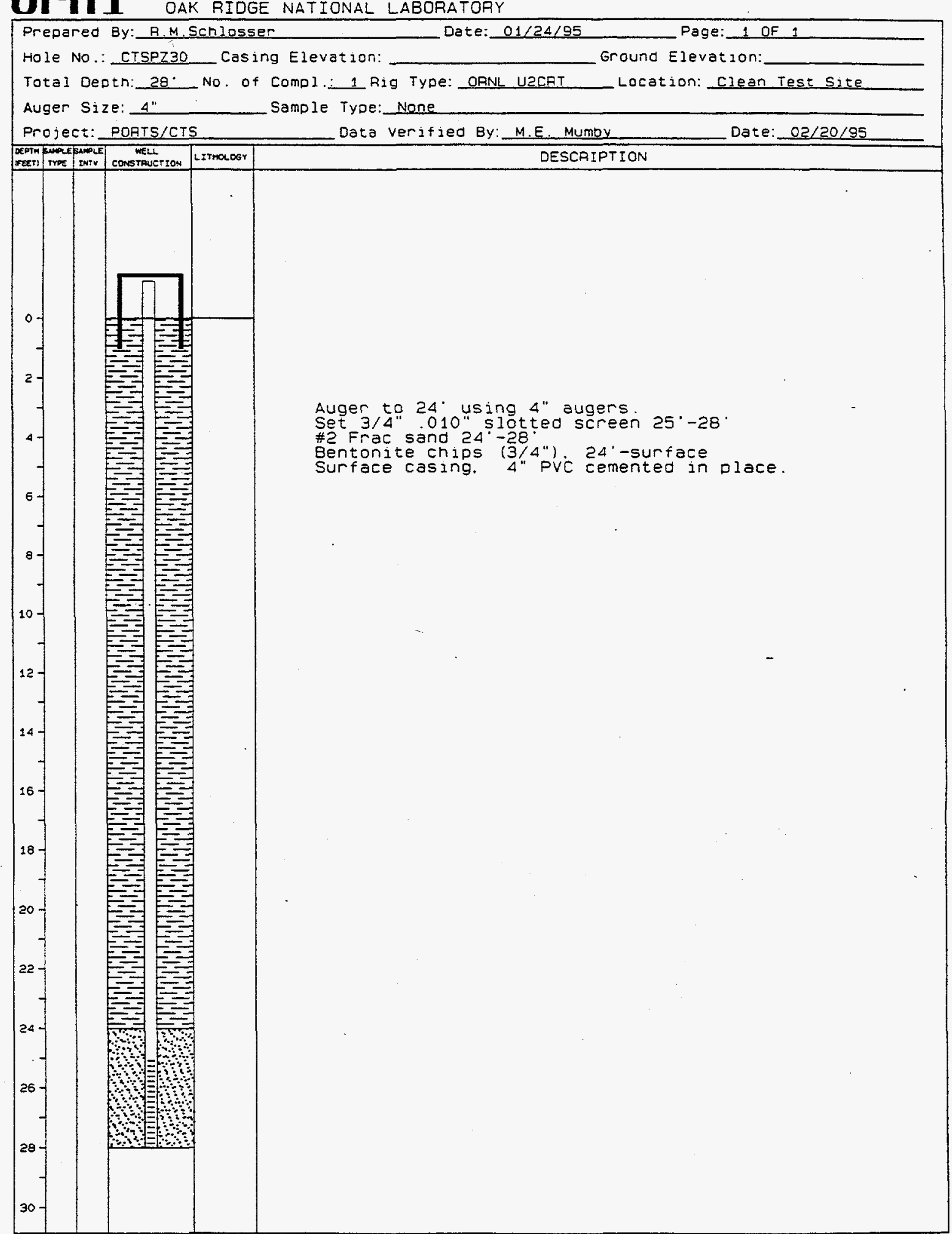


0II OAK RIOGE National LabORATORY

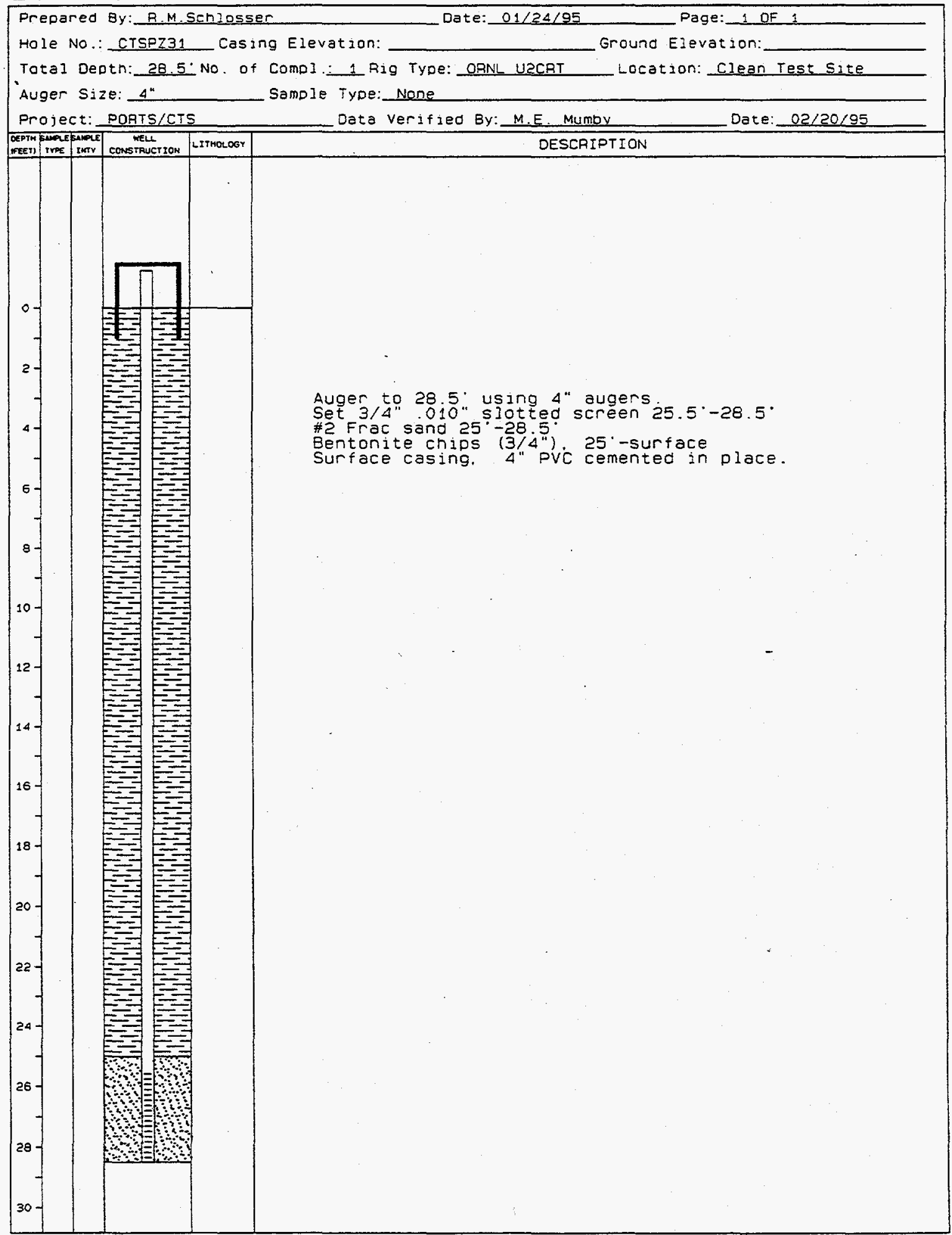


Or] Piezometer Summary Information

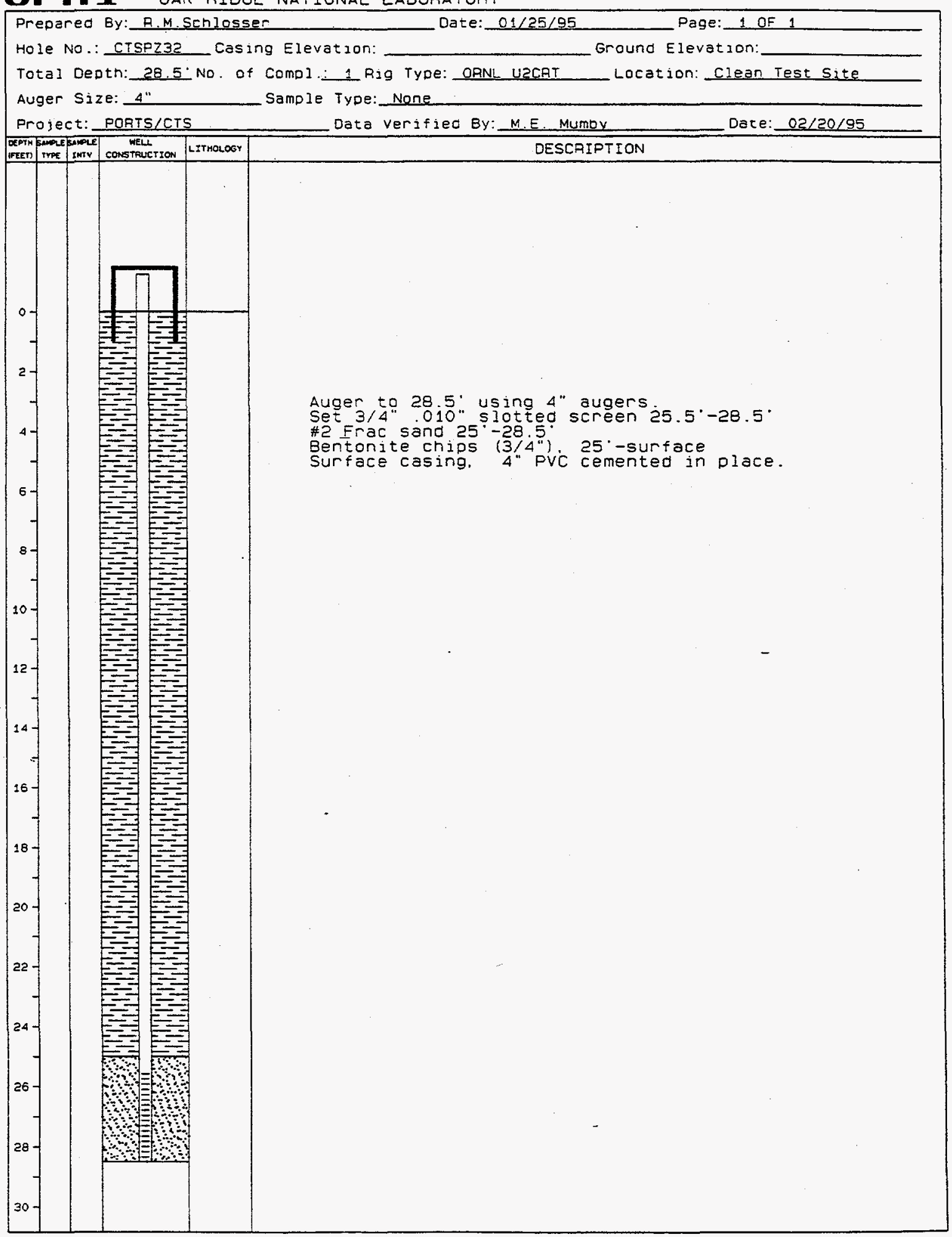


Piezometer Summary Information

OII OAK RIDGe national Laboratory

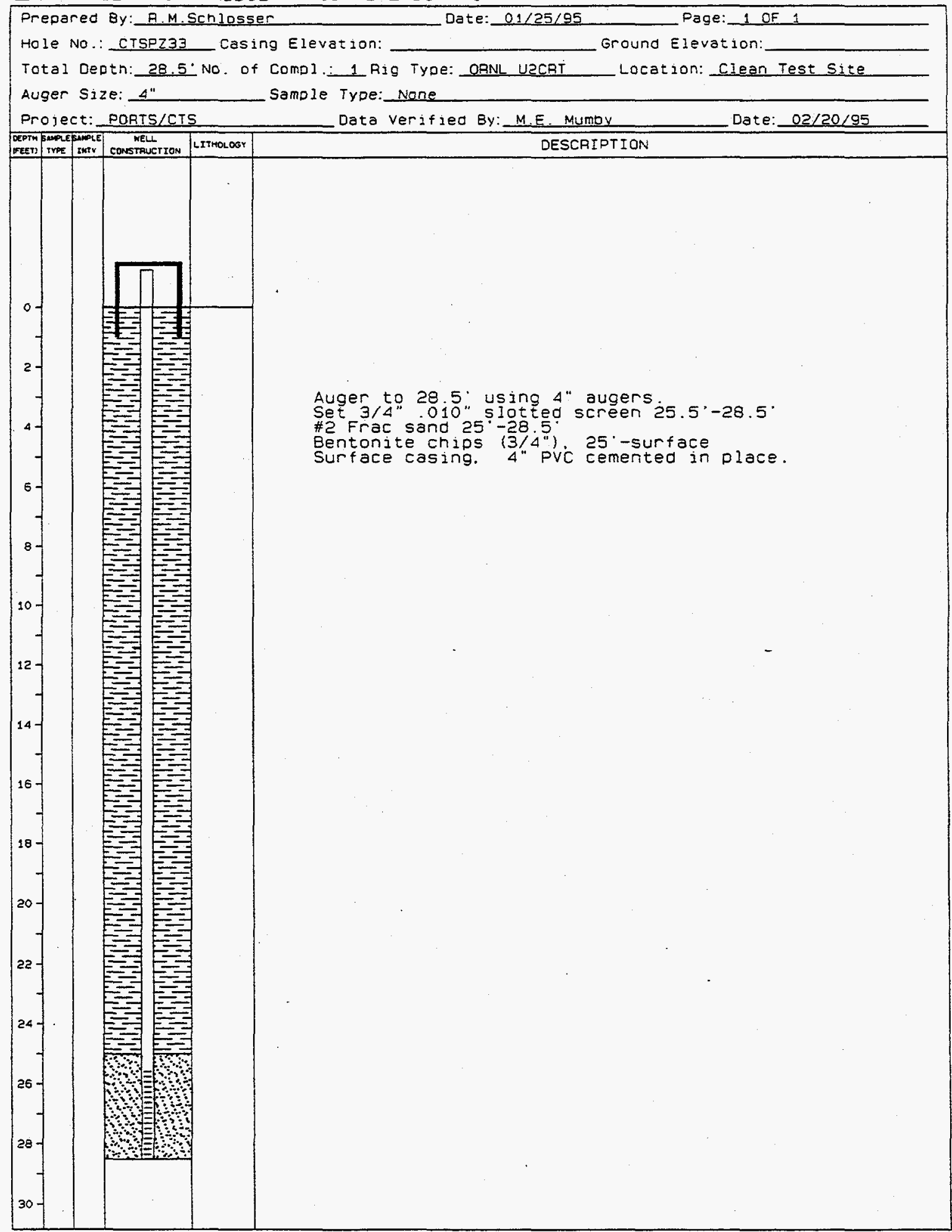


Appendix D

Pressure Transducer Data from the West Well Pumping Test 


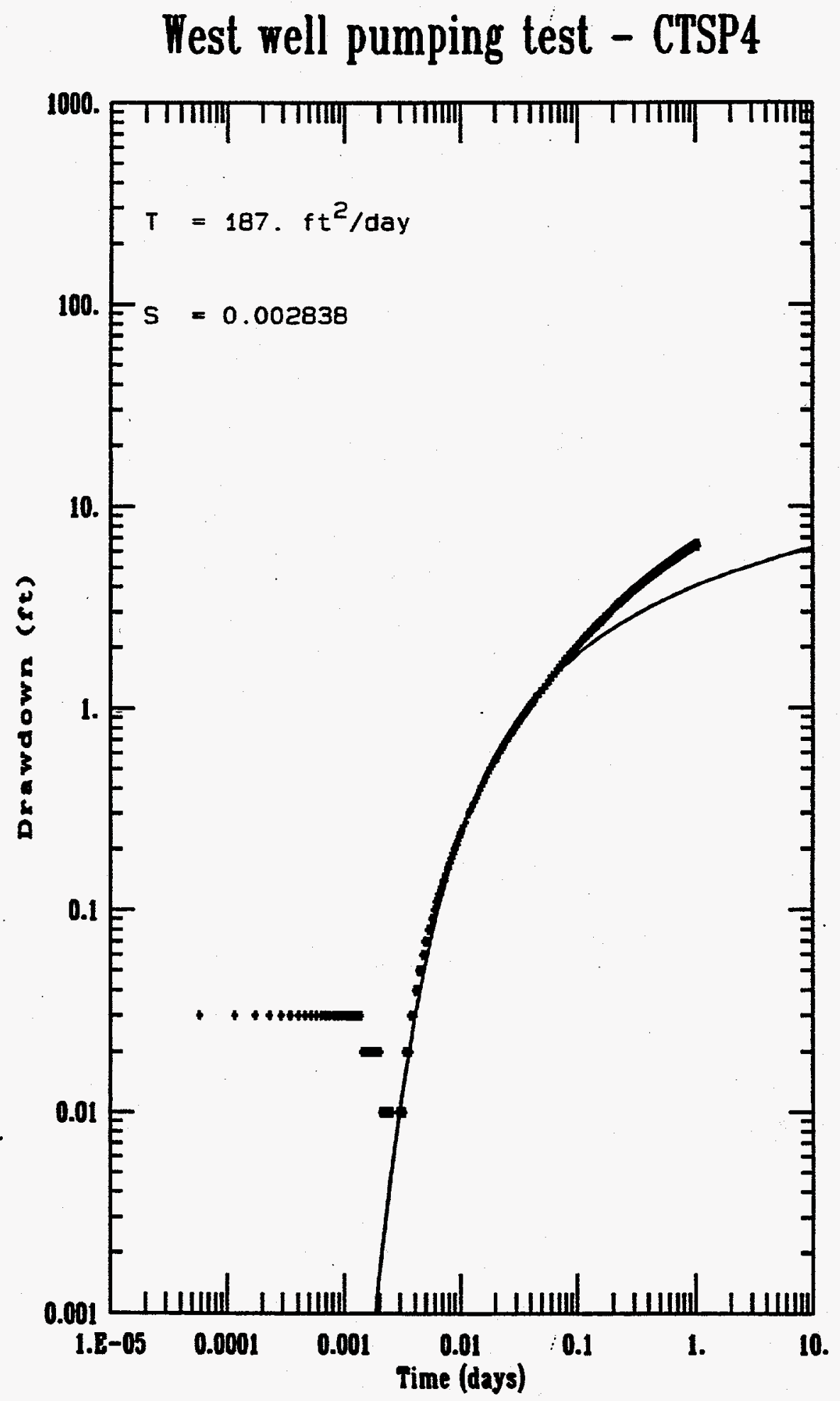




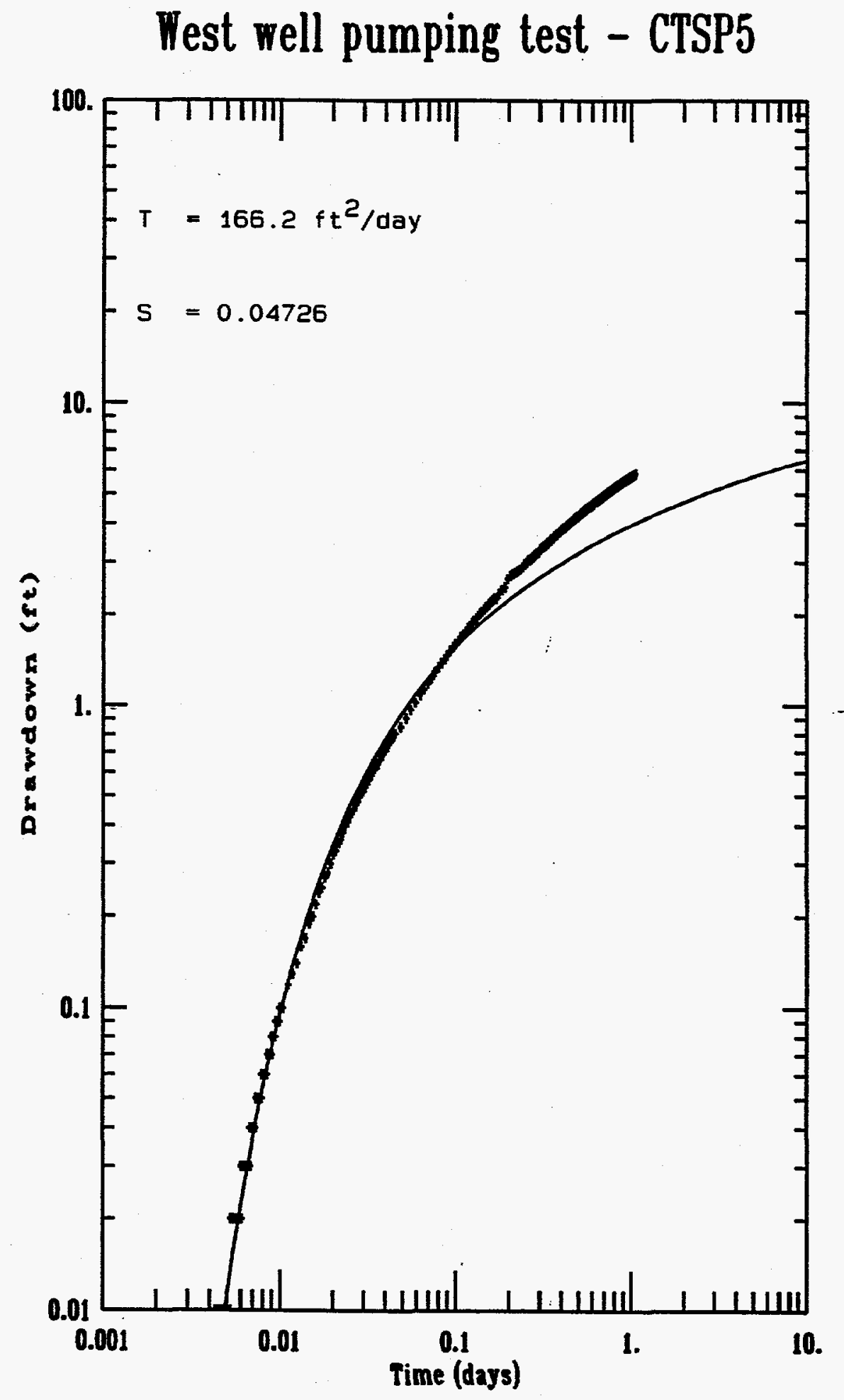




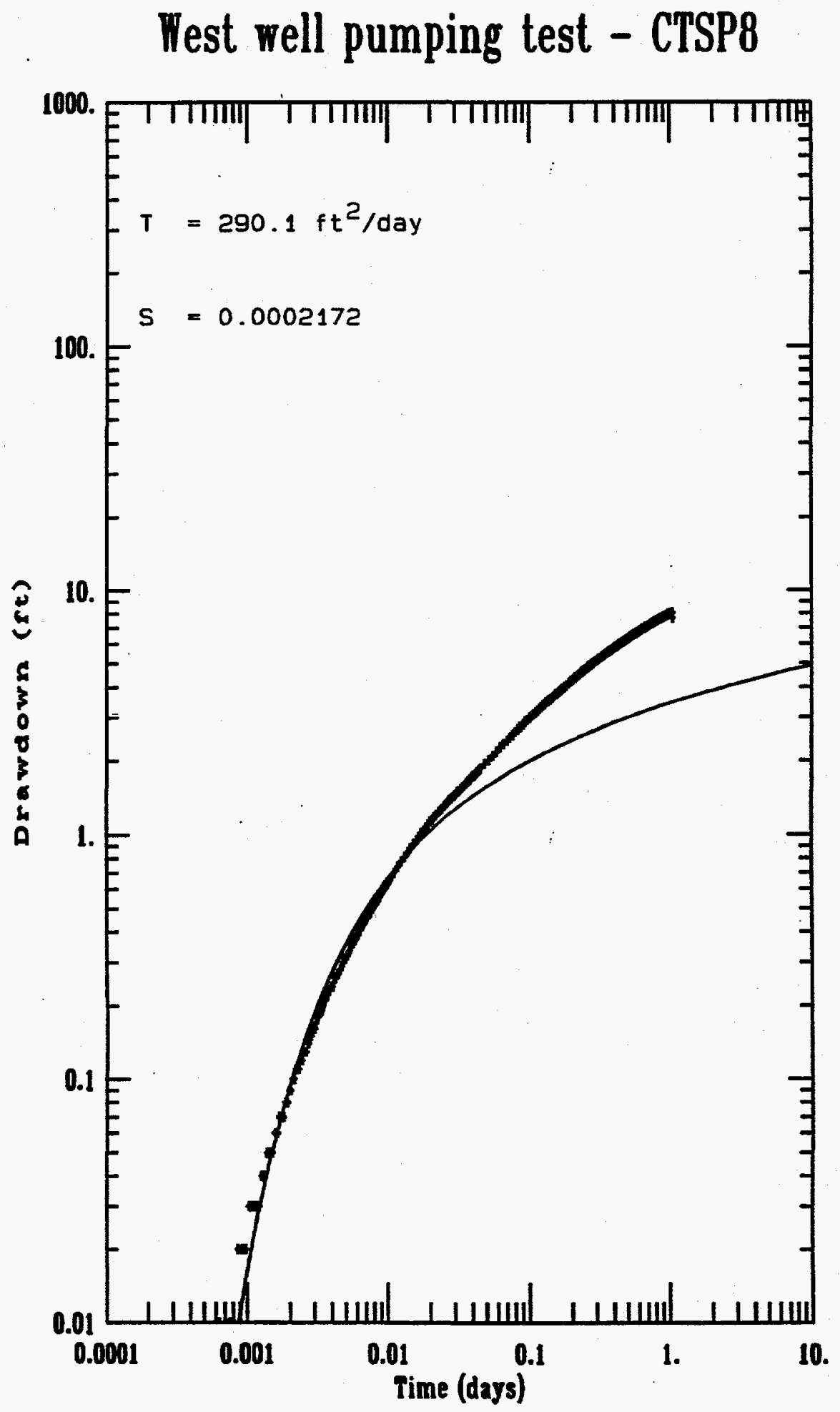




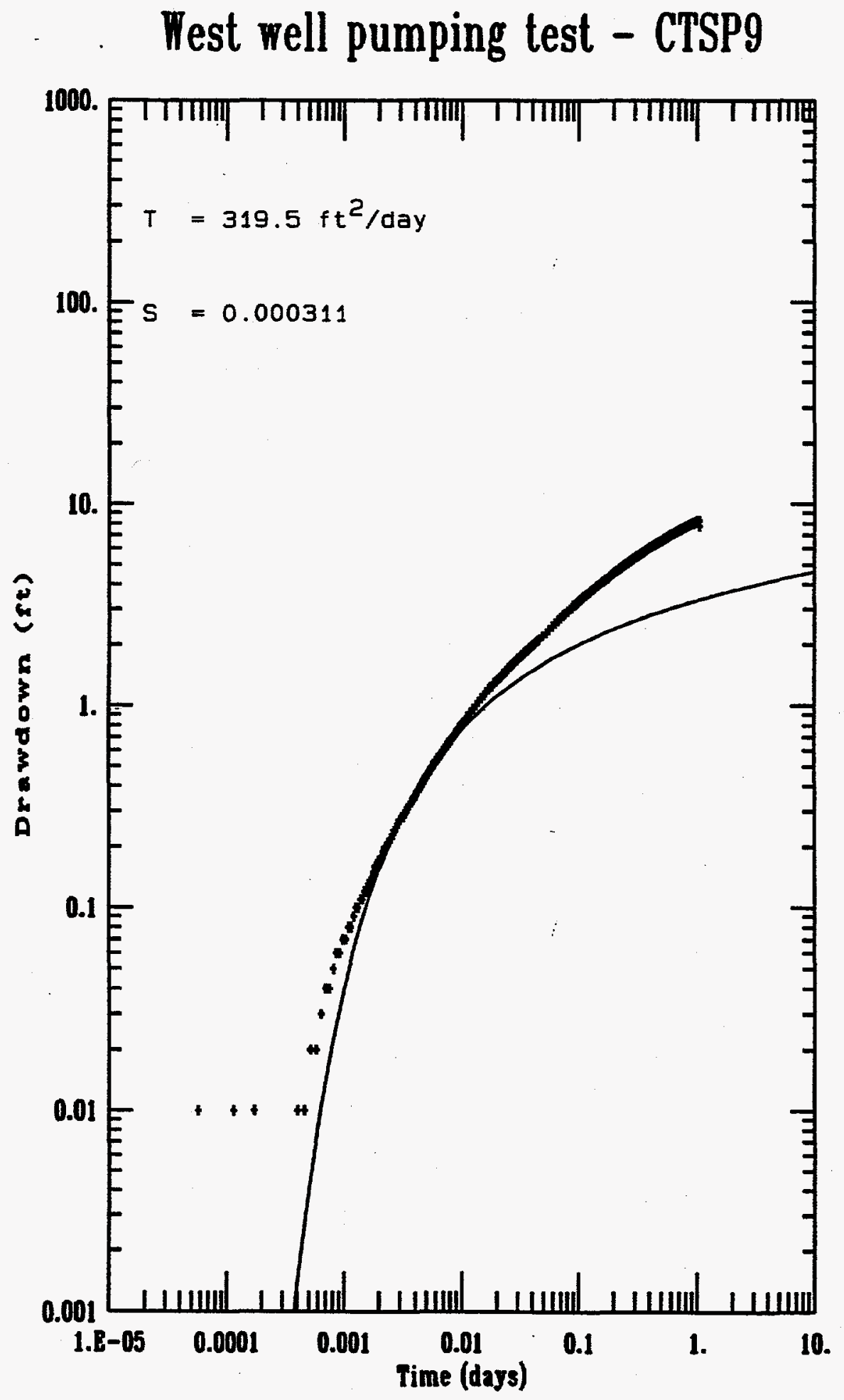




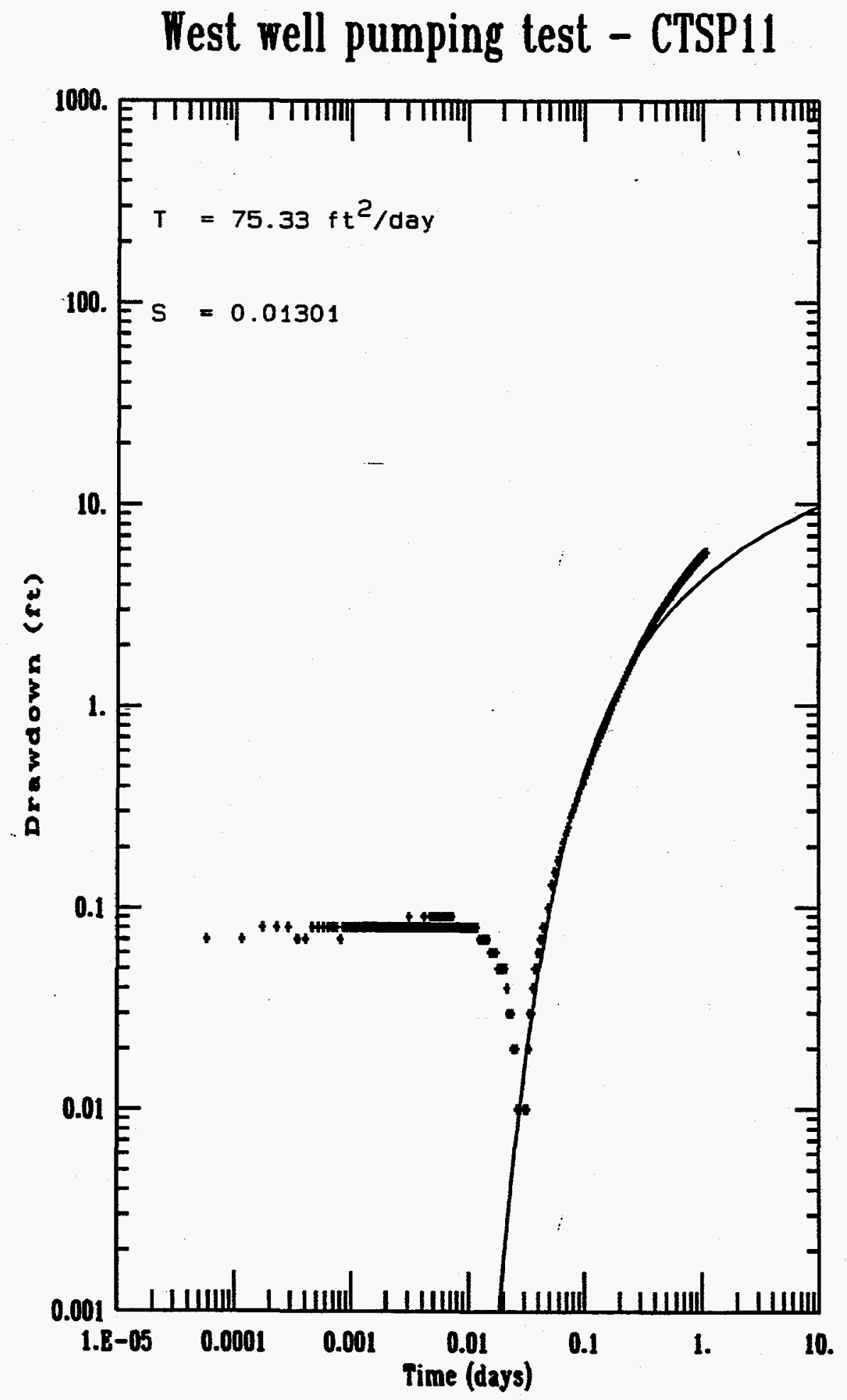




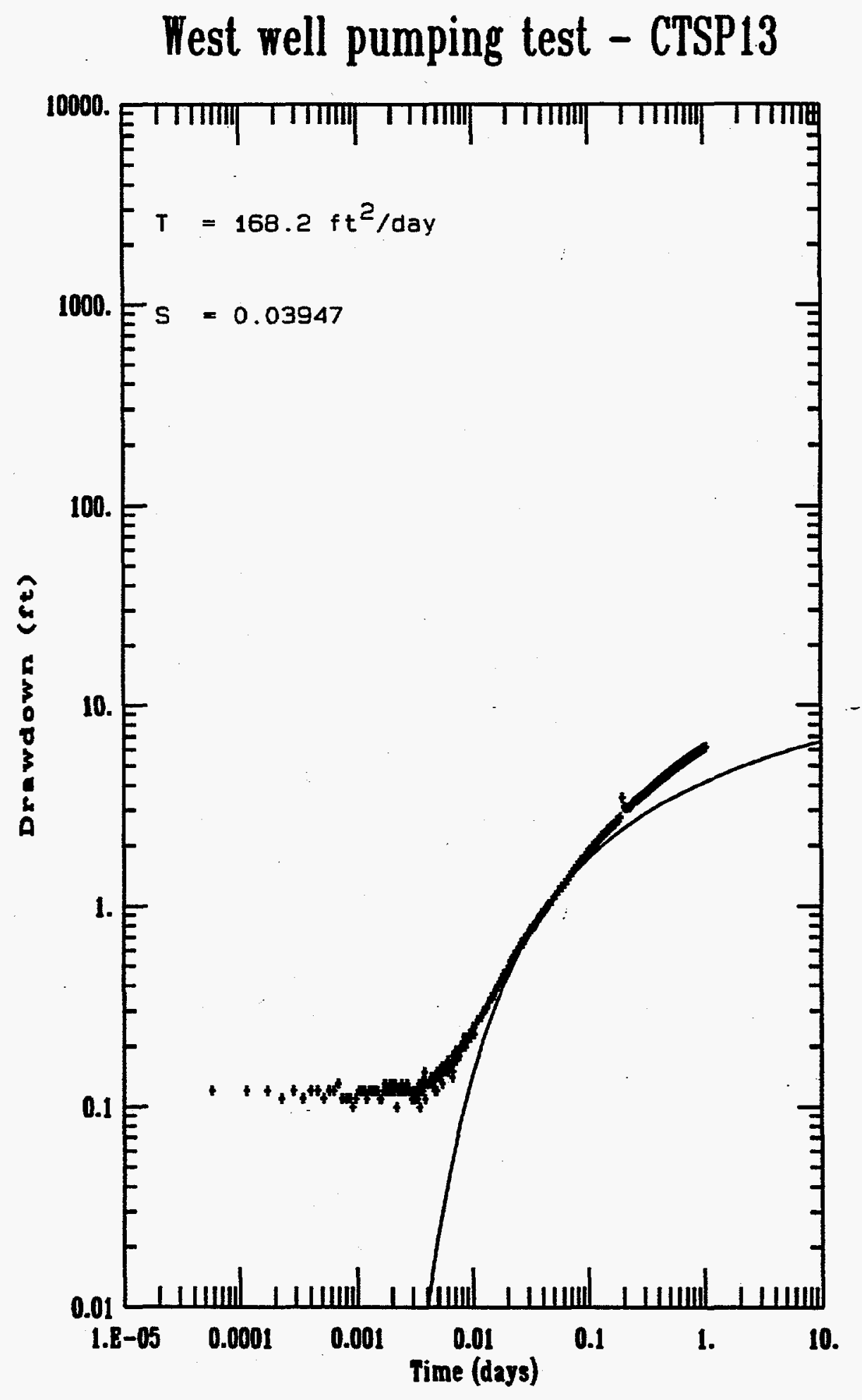




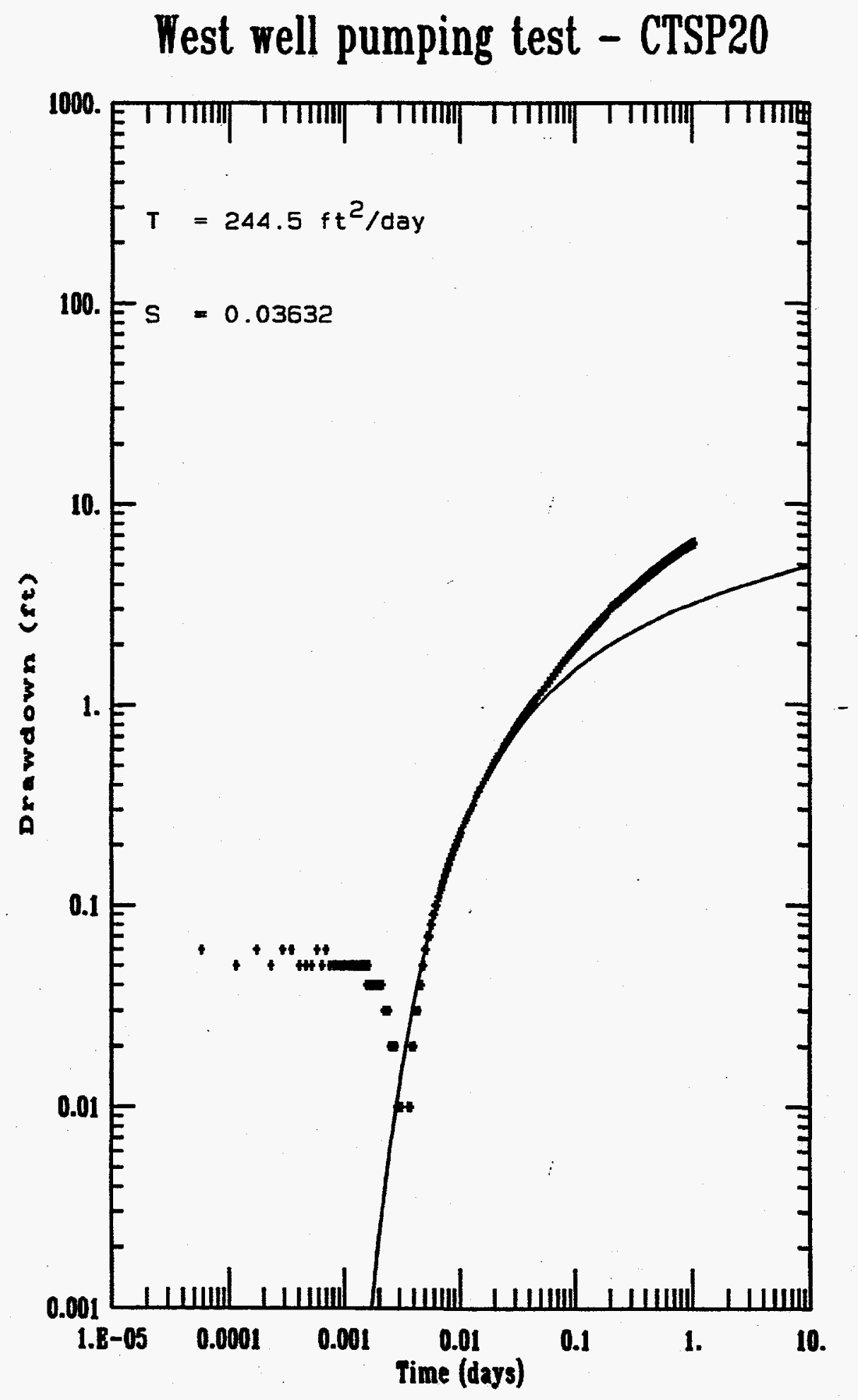


Appendix E

Pressure Transducer Data from the East Well Pumping Test 


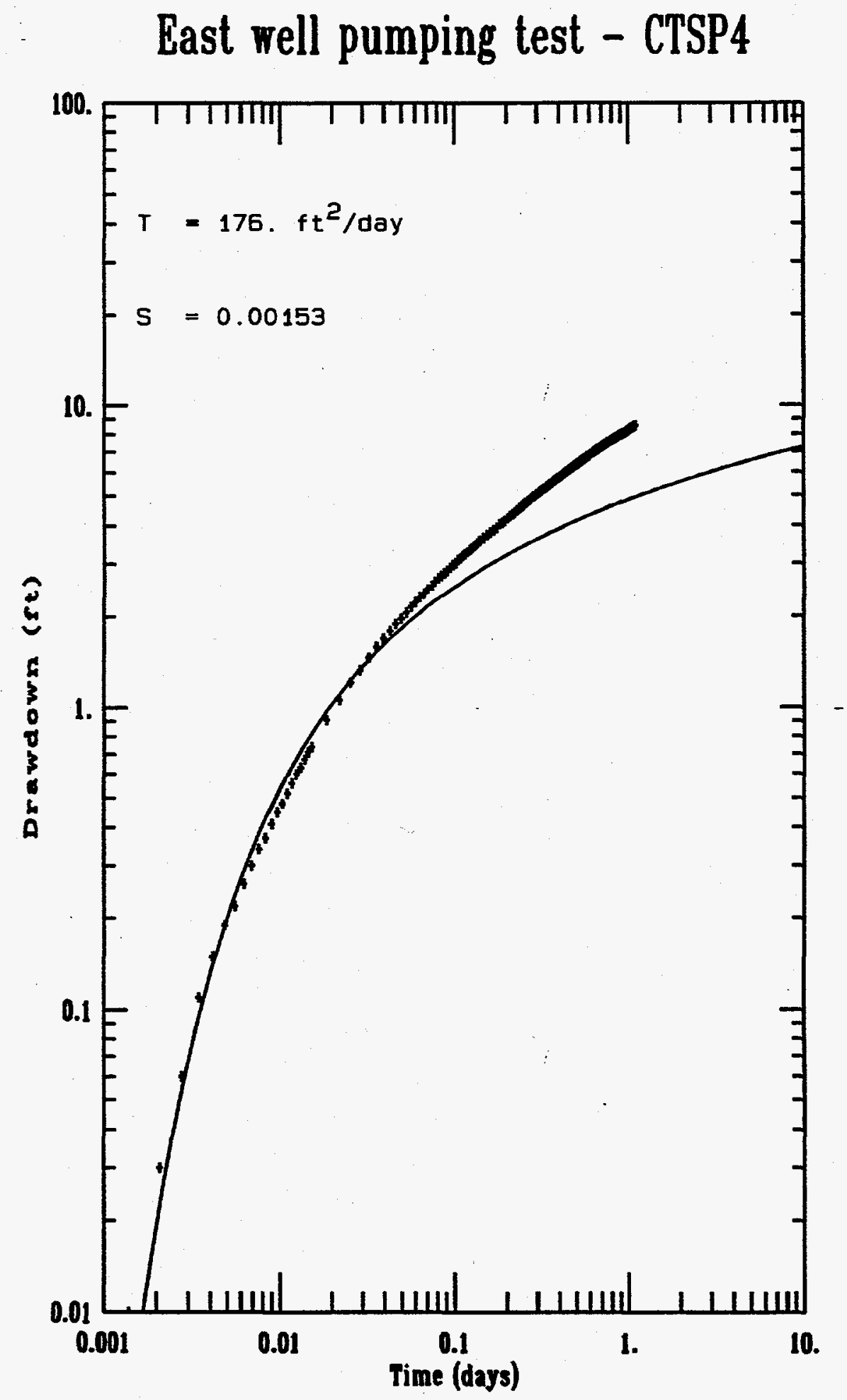




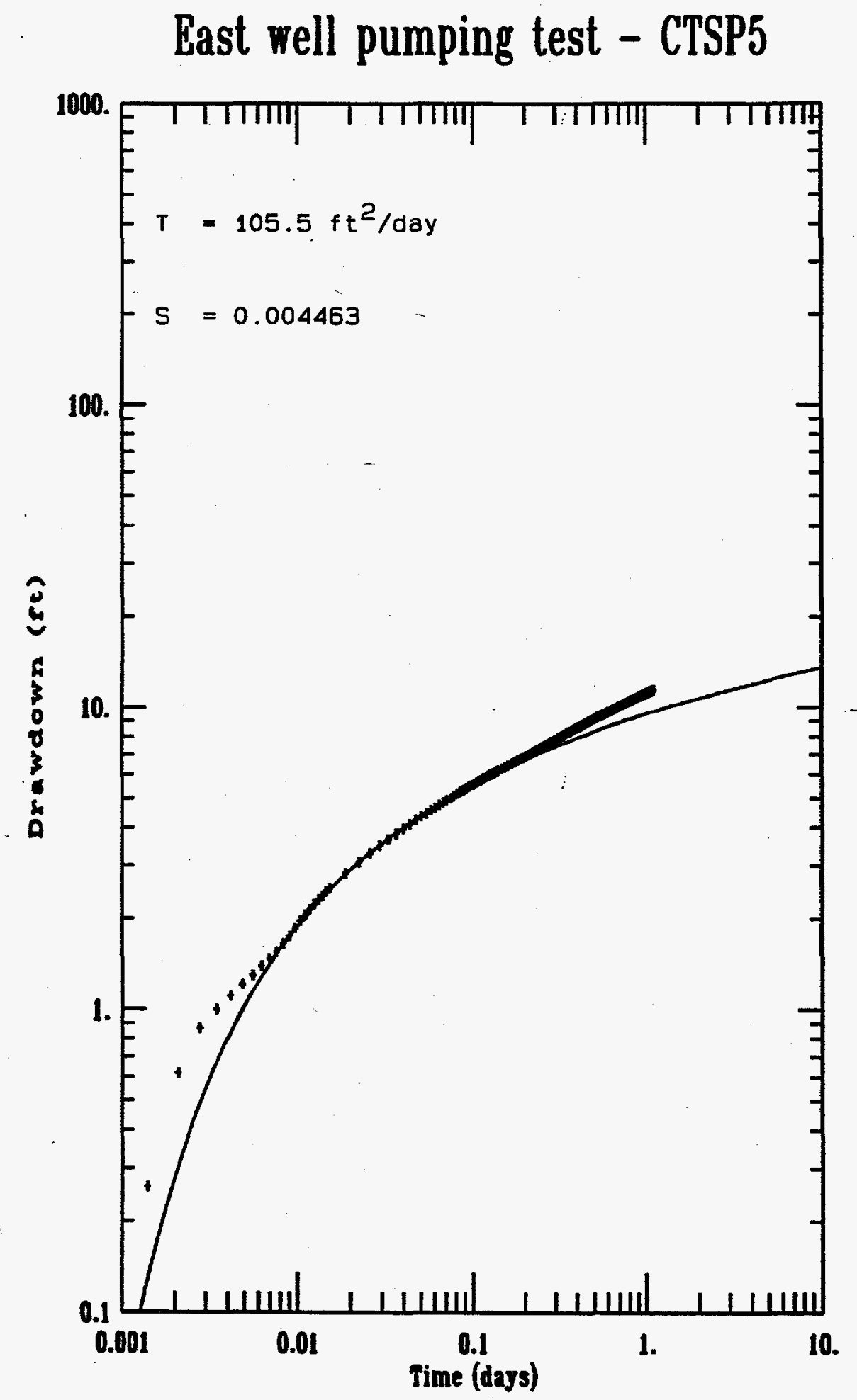




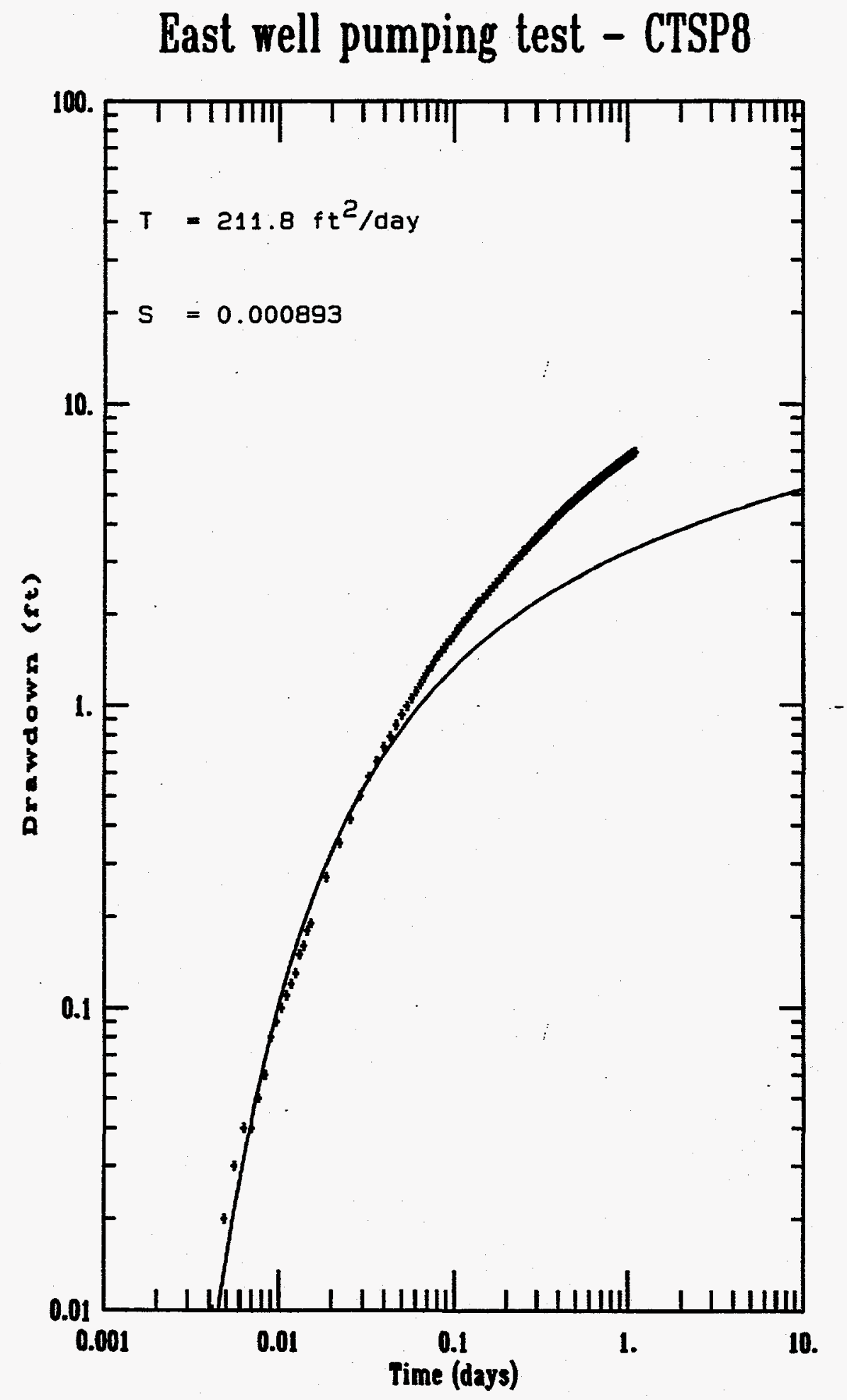


East well pumping test - CTSP9

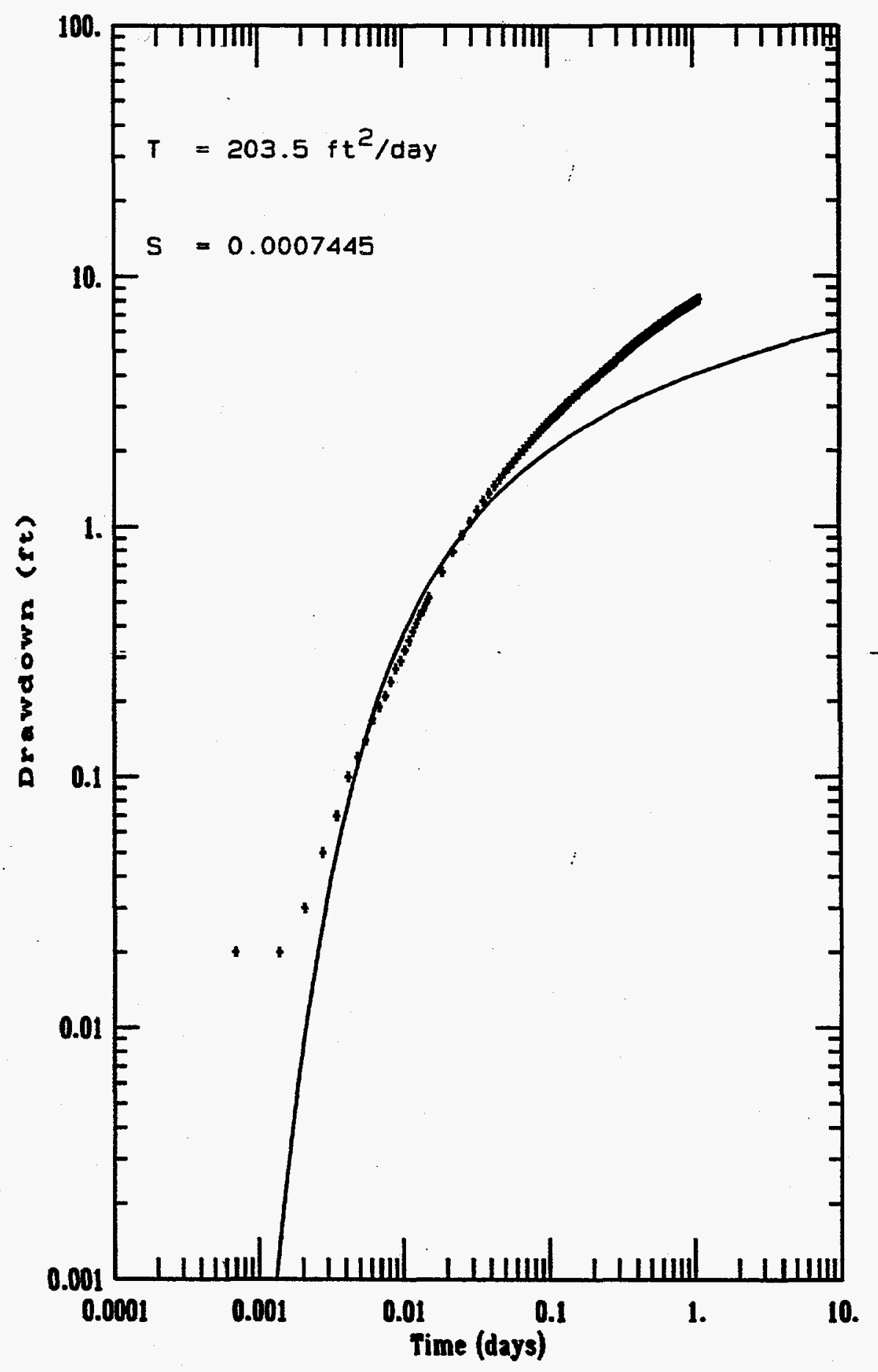




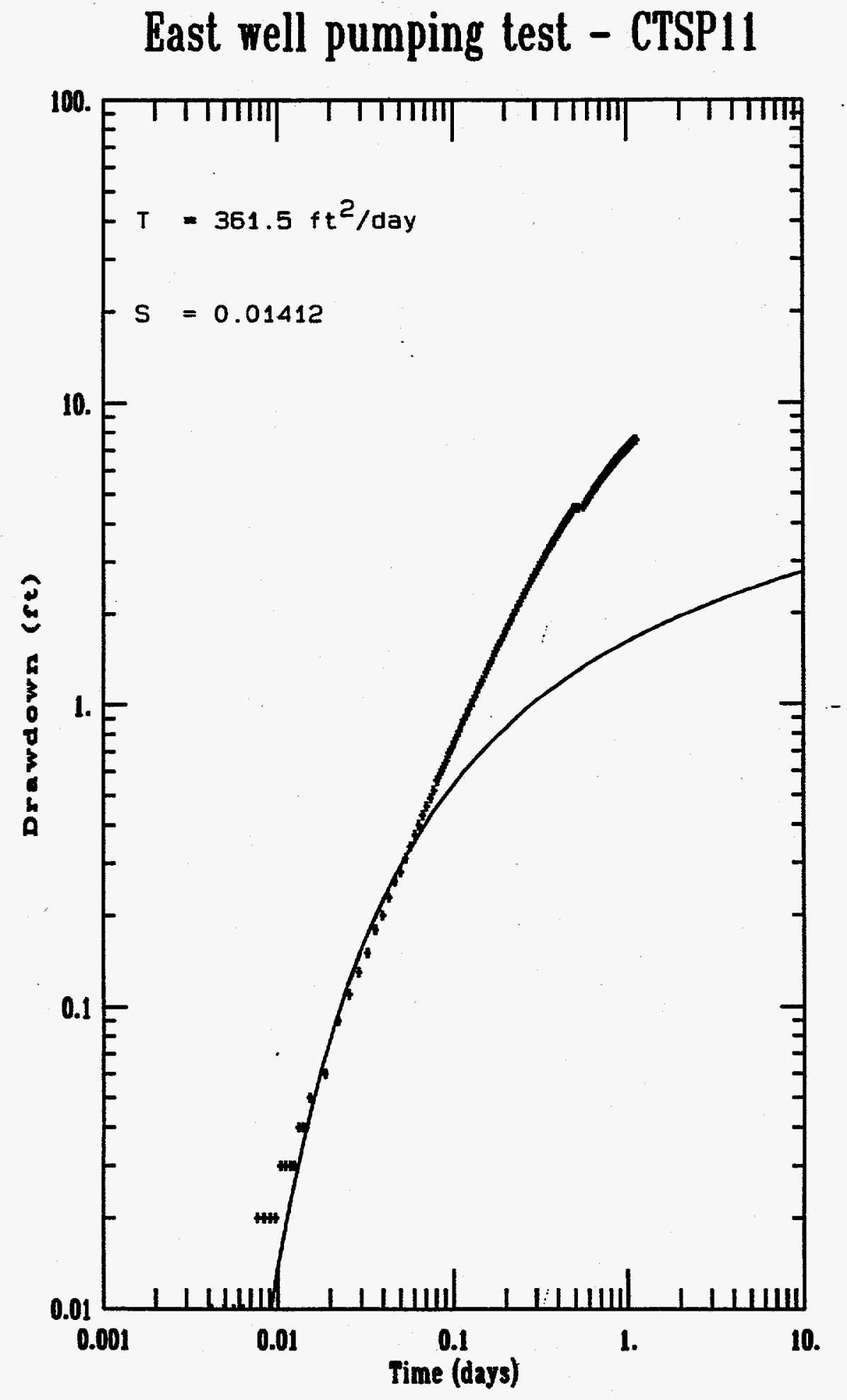




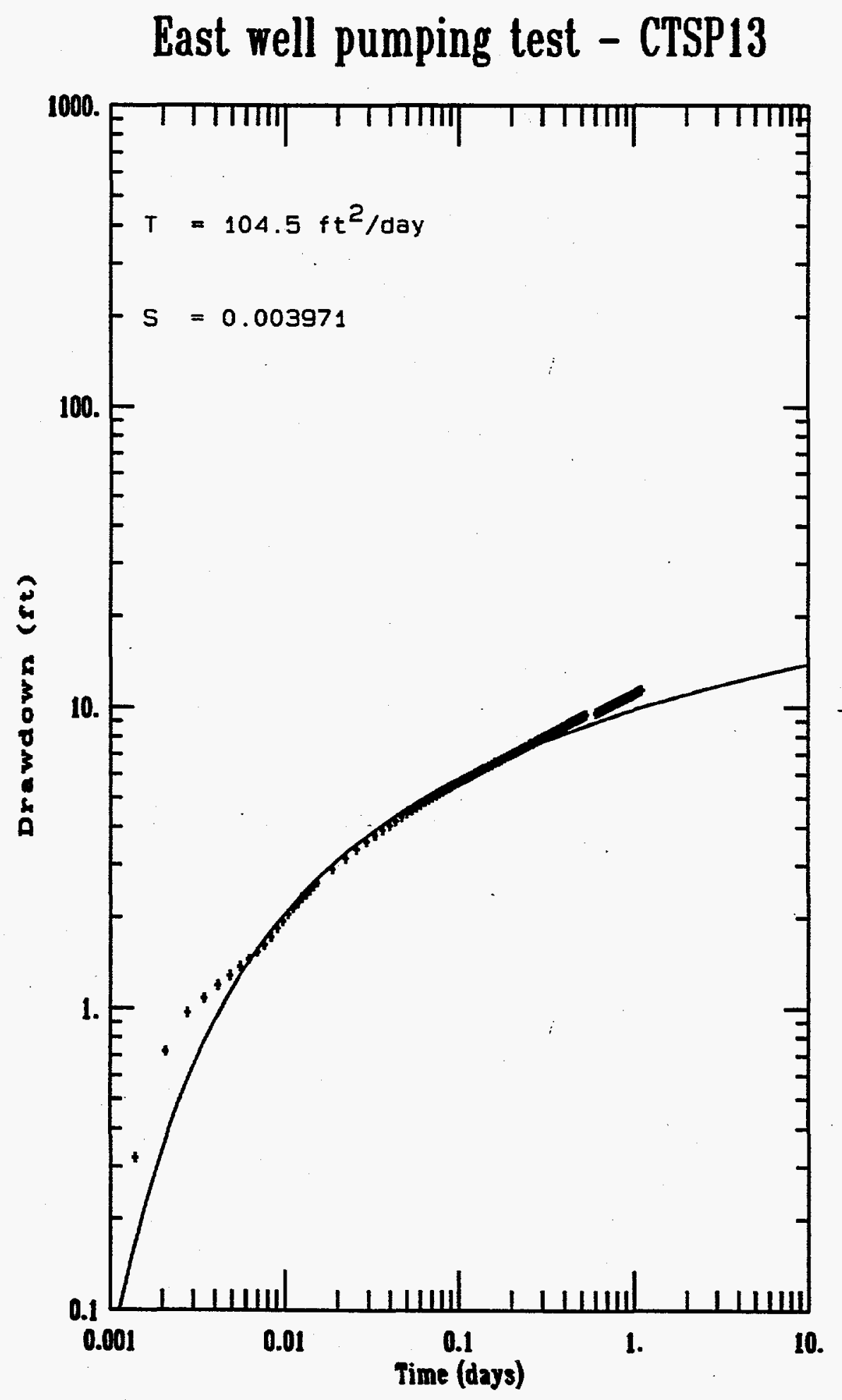




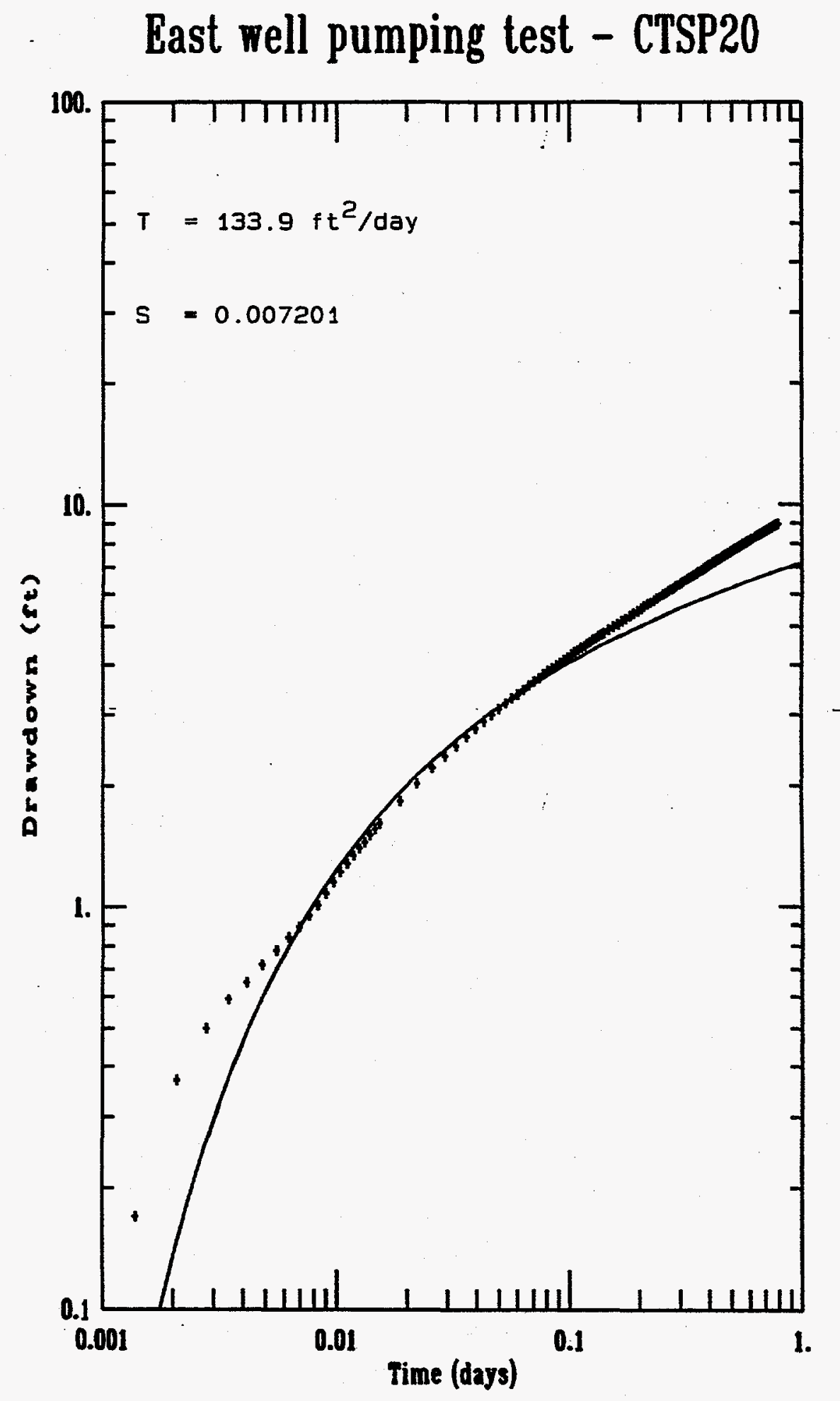


Appendix $\mathrm{F}$

Pressure Transducer Data from Dual Well Horizontal Recirculation Test 


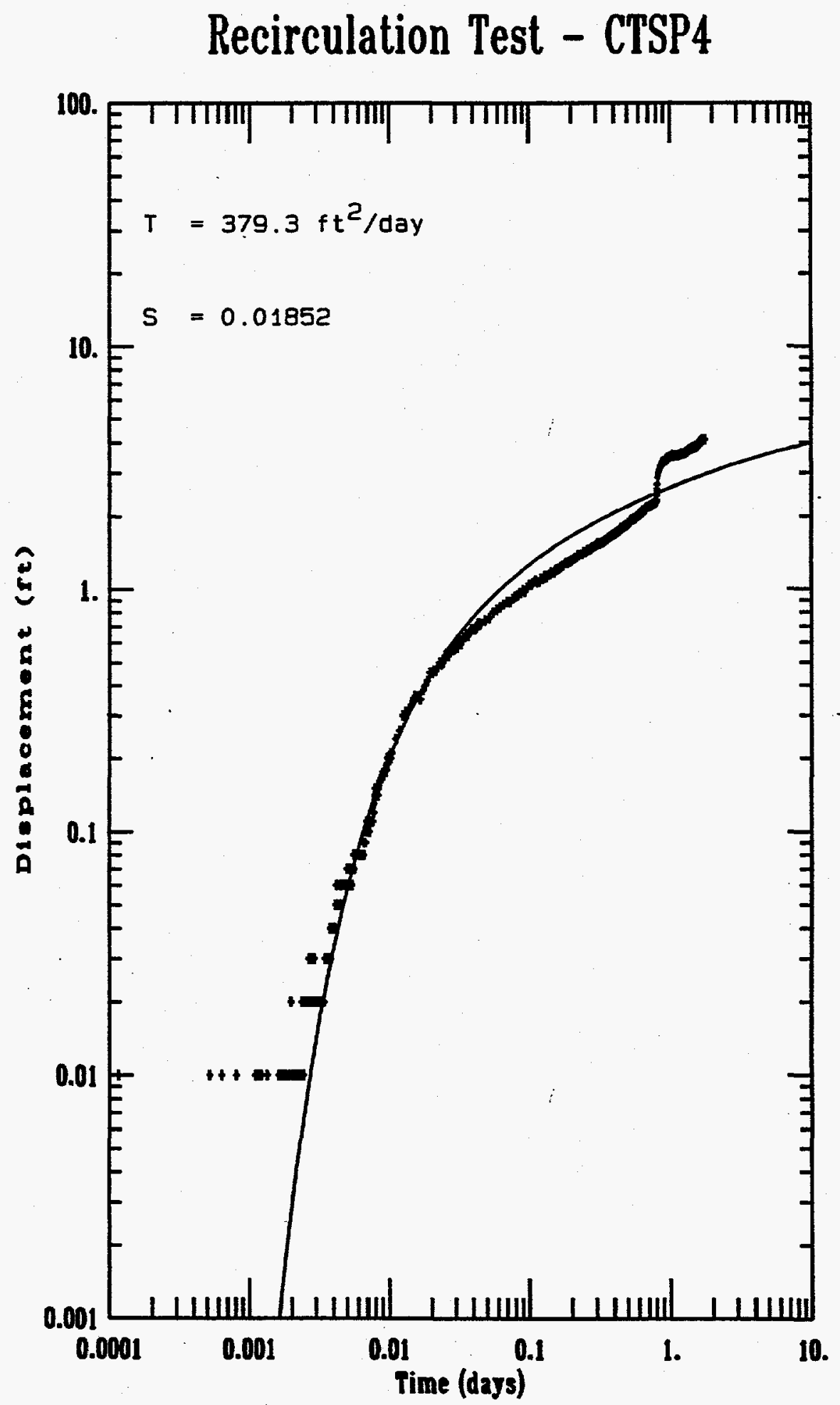




\section{Recirculation Test - CTSP5}

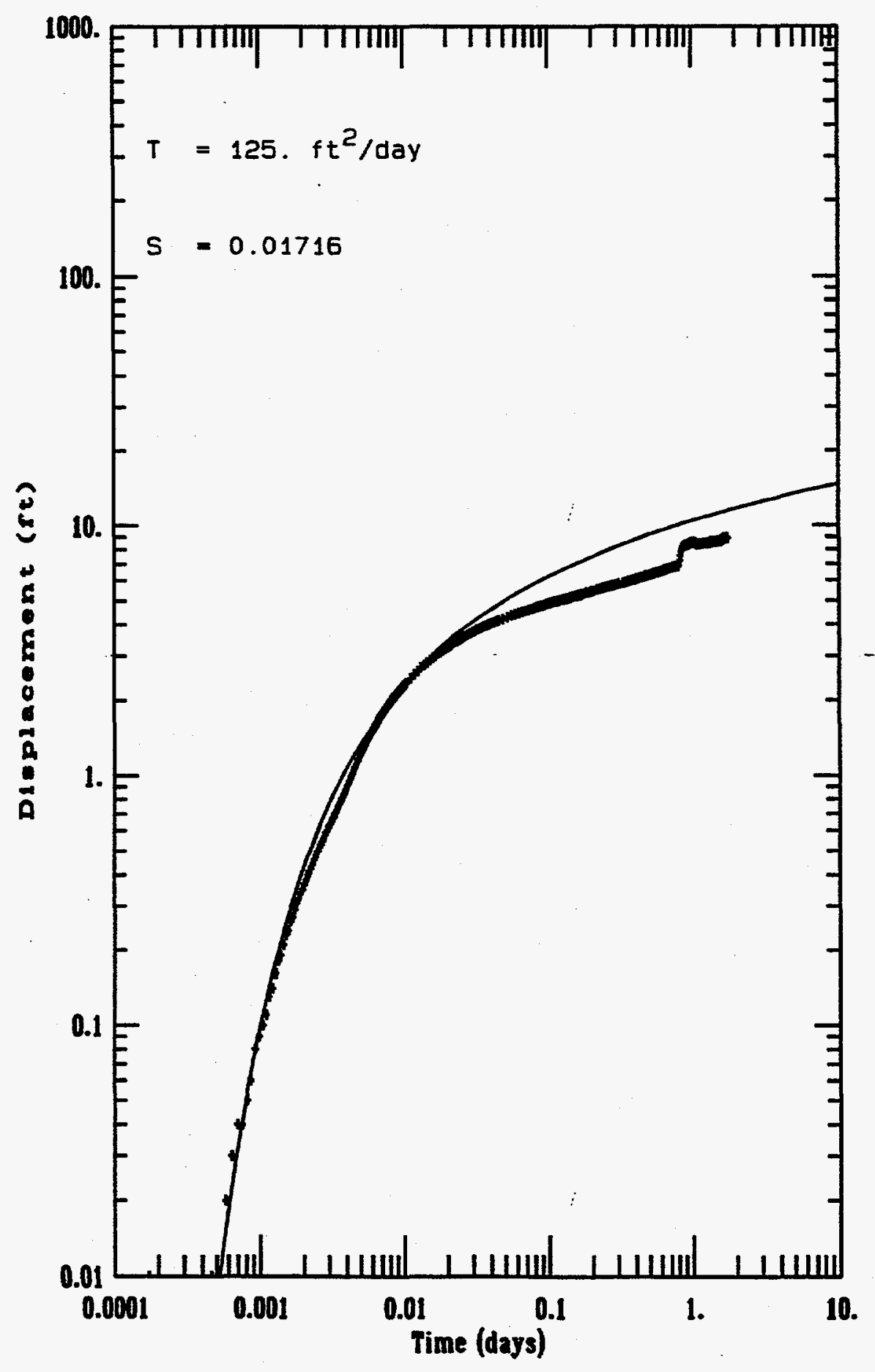




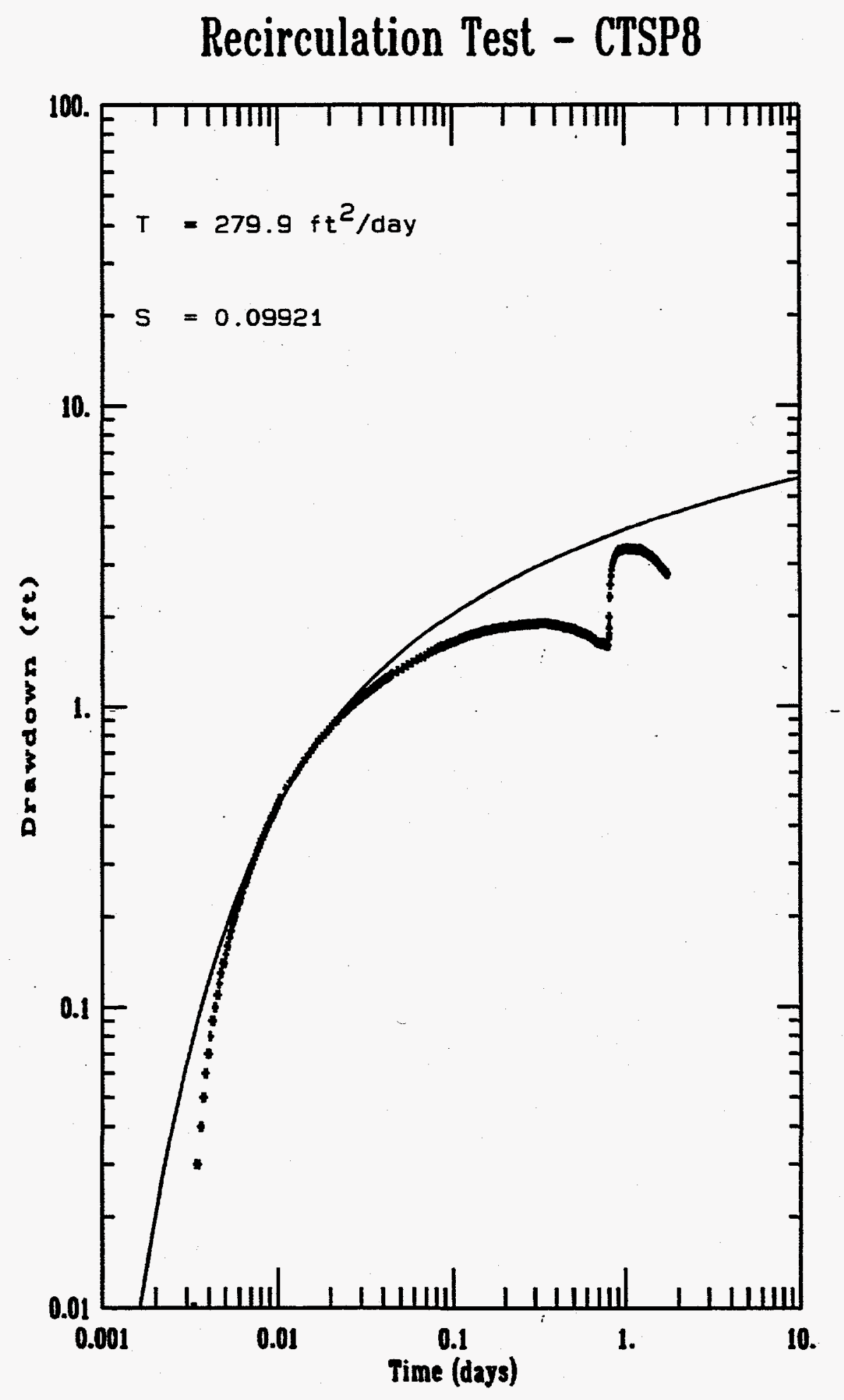




\section{Recirculation Test - CTSP9}

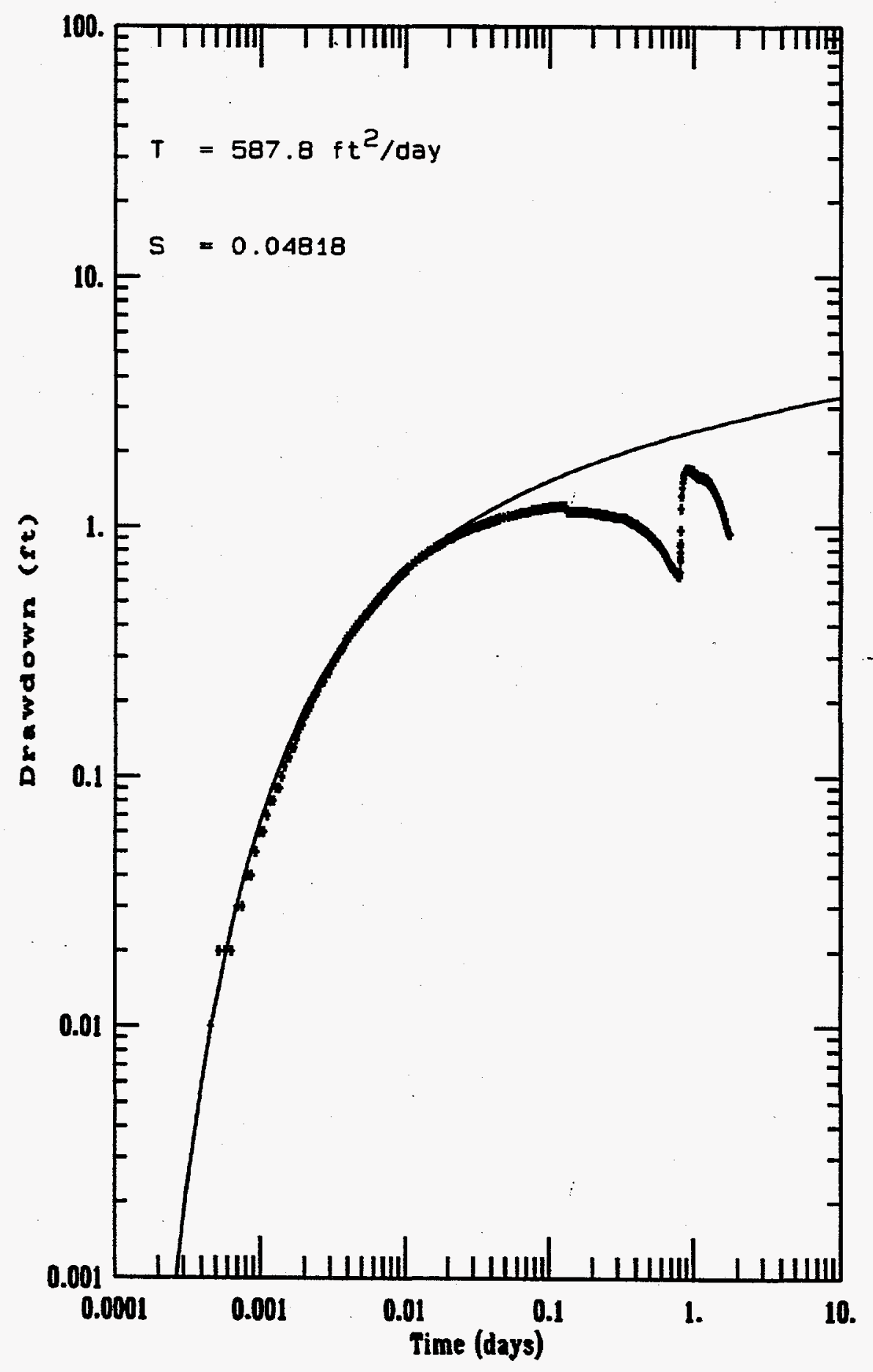


Recirculation Test - CTSP11

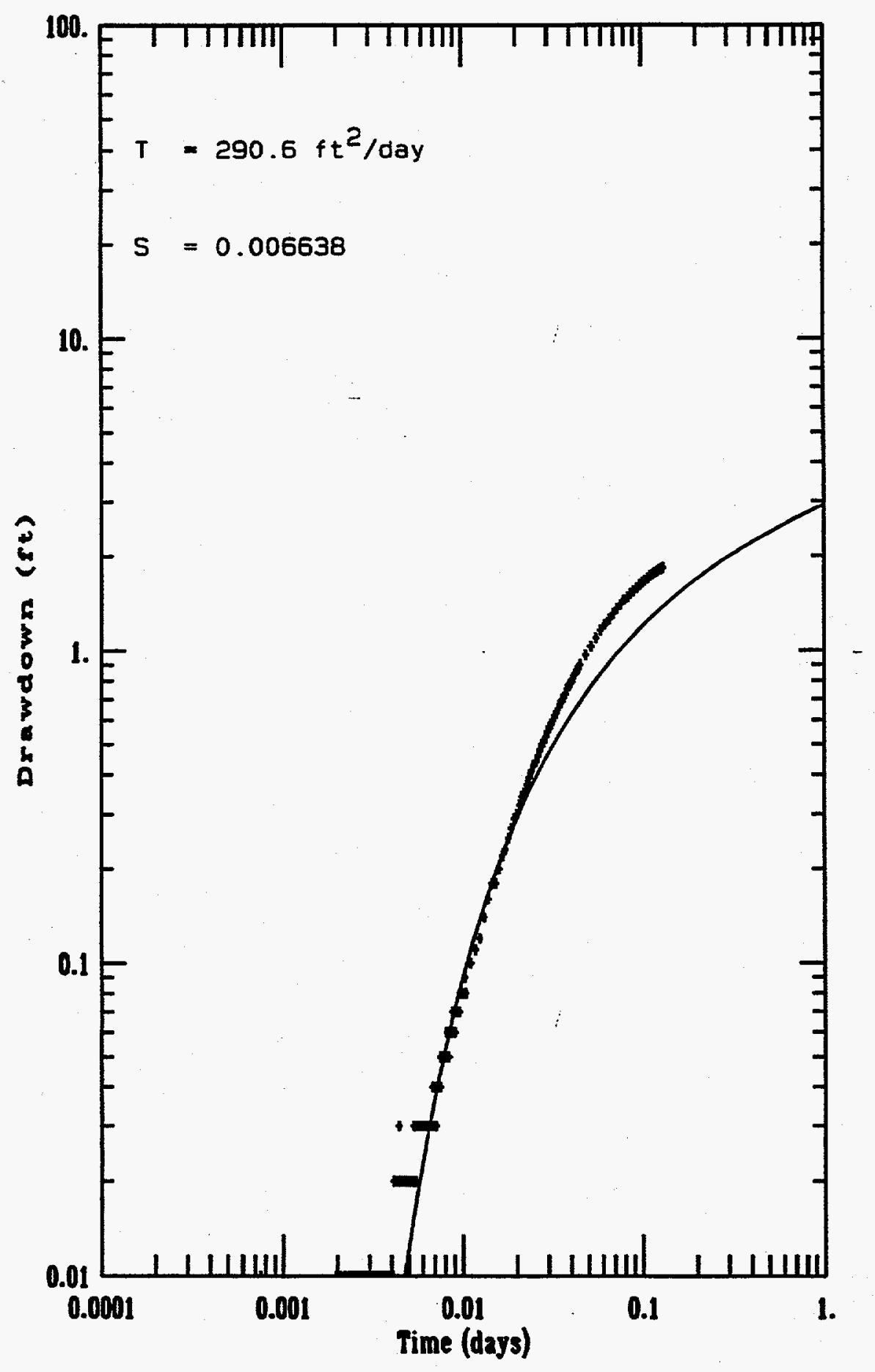




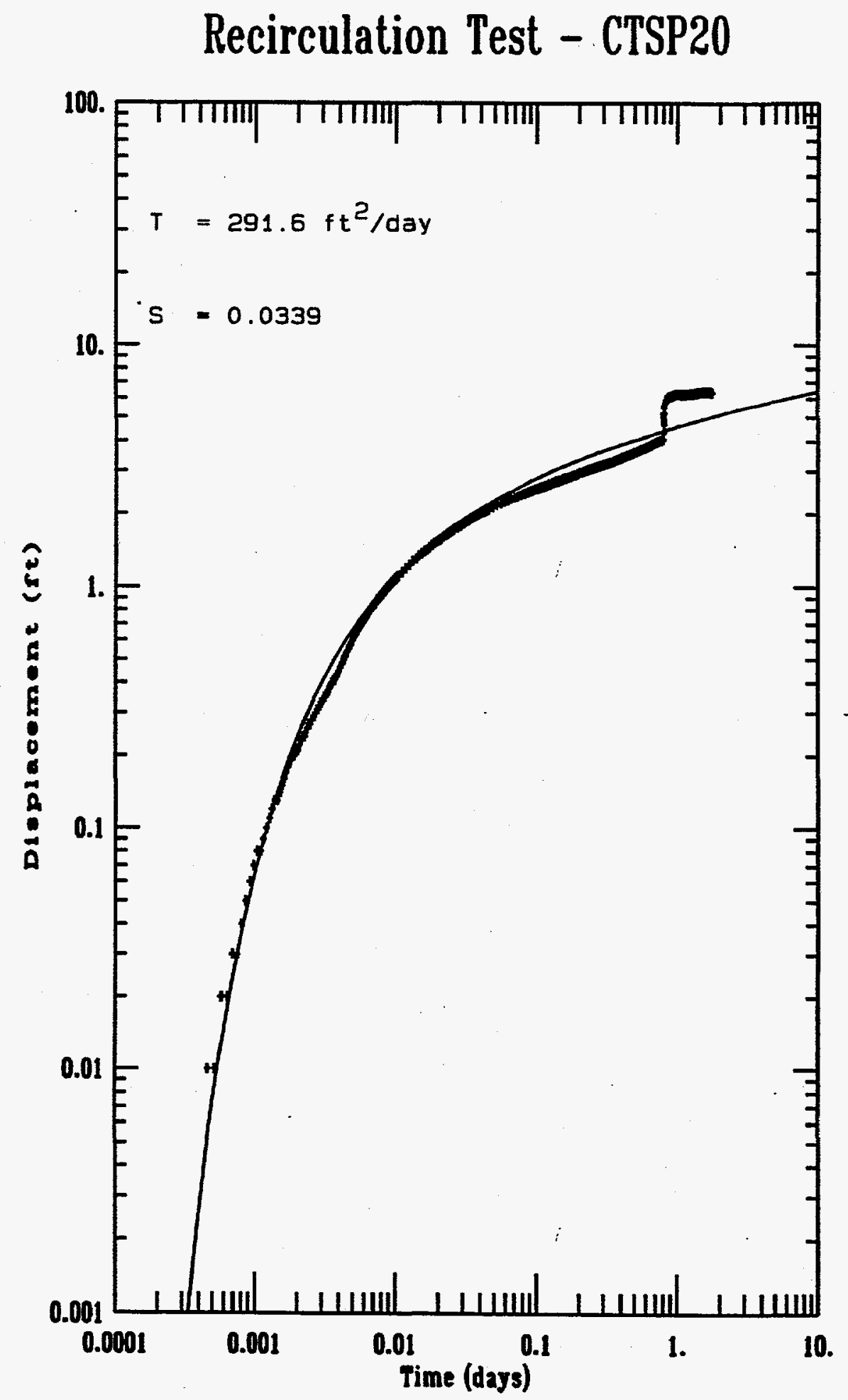


Appendix G

Groundwater Velocity Data Gathered by the Colloidal Borescope for Selected Piezometers 


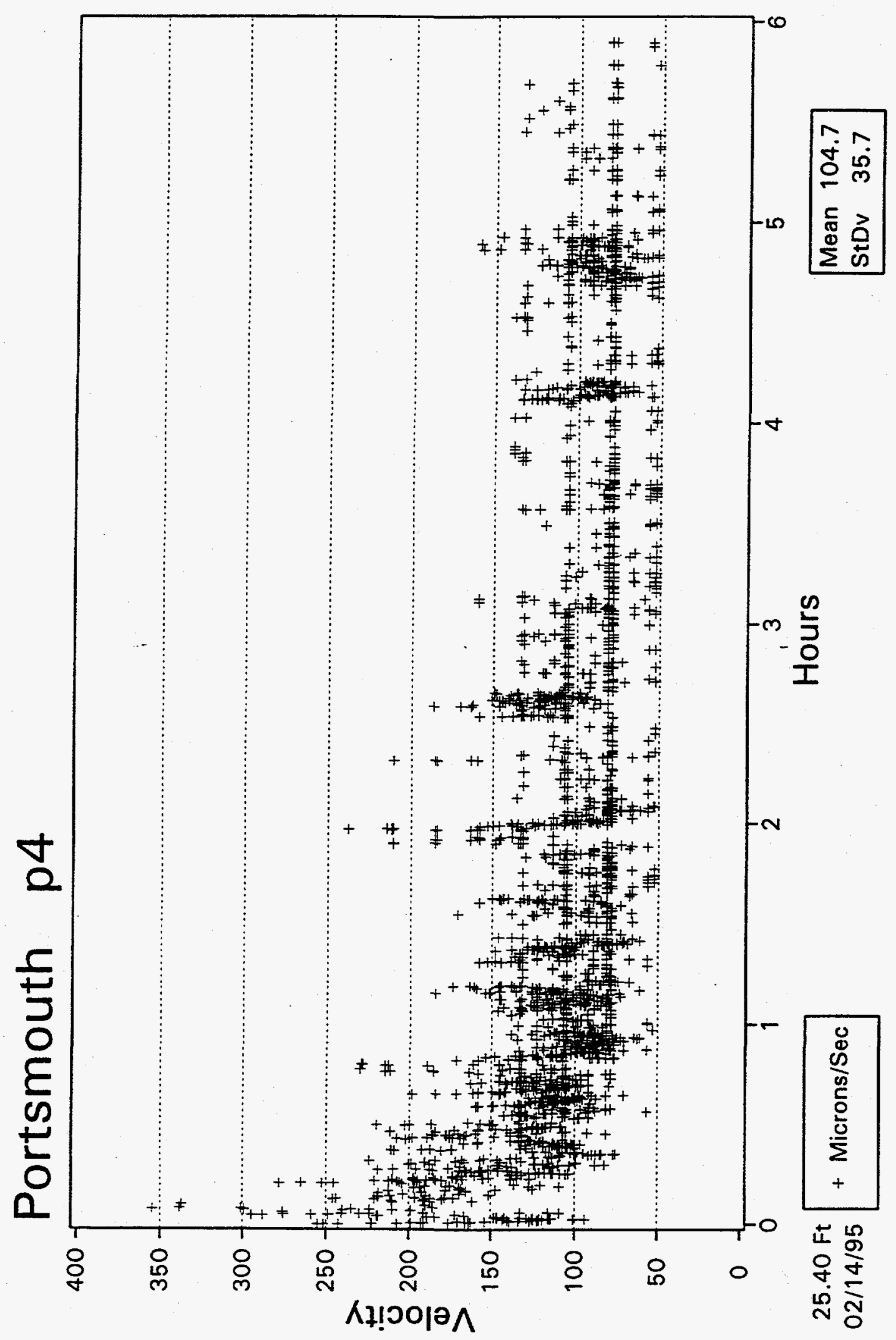




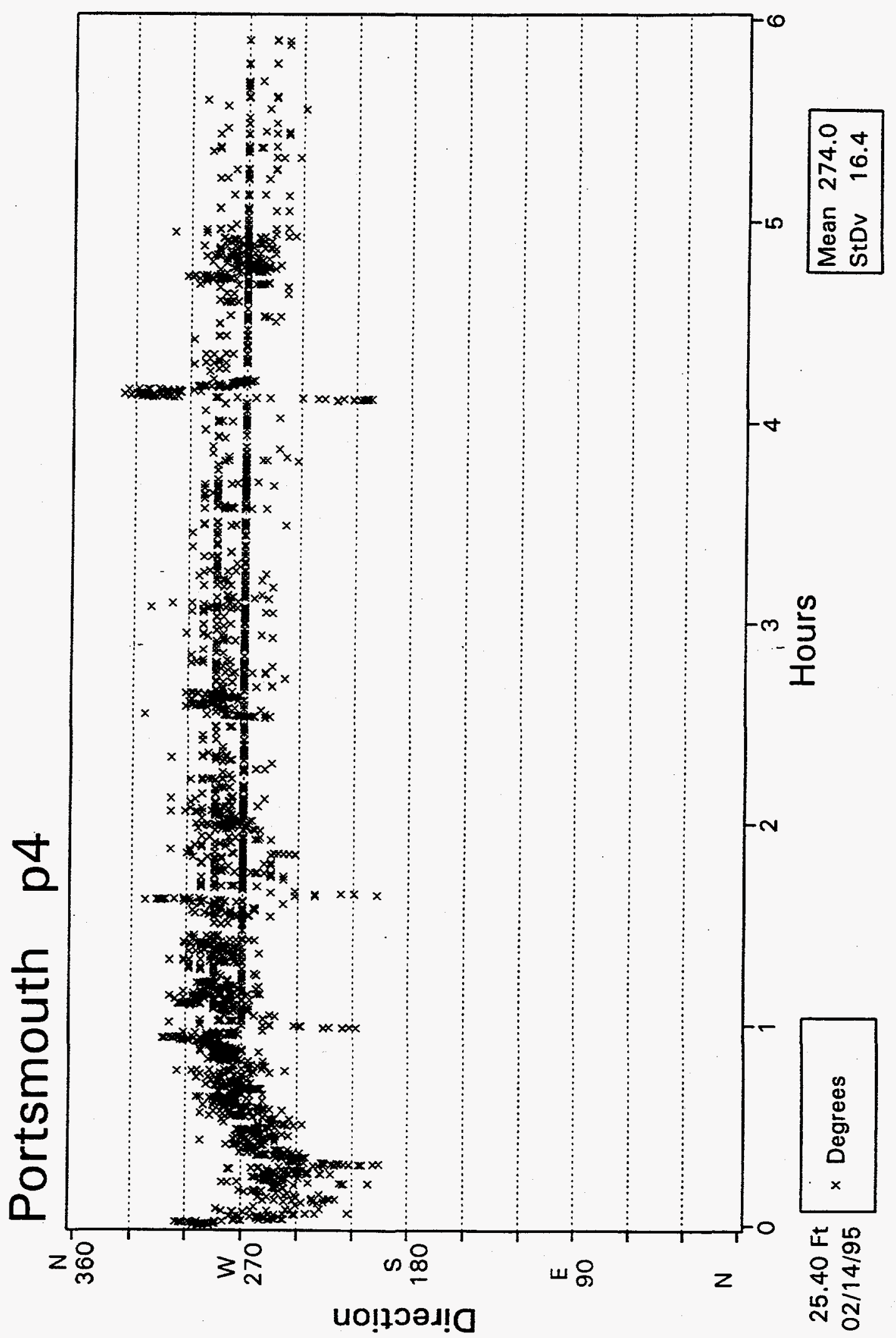




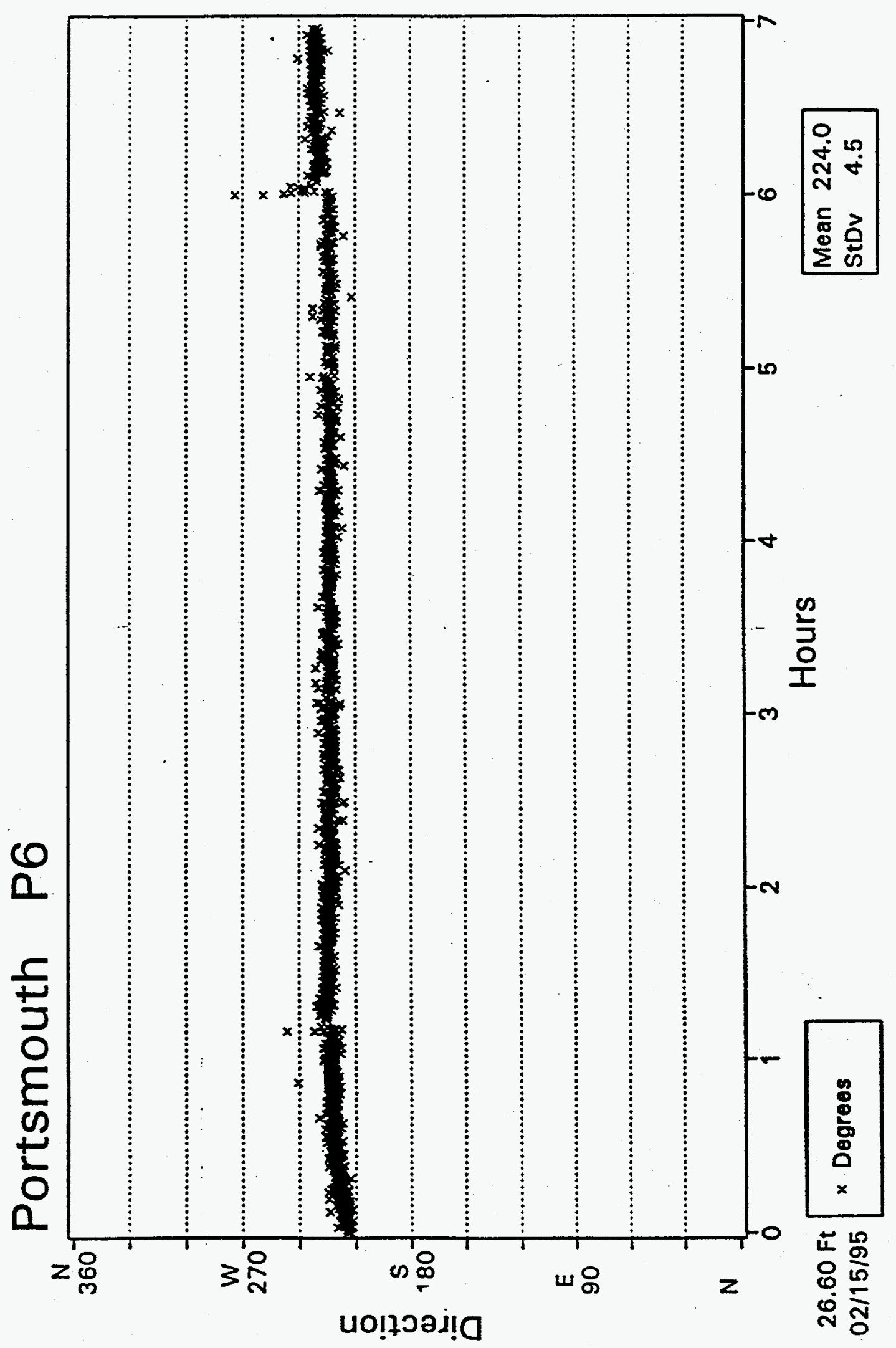




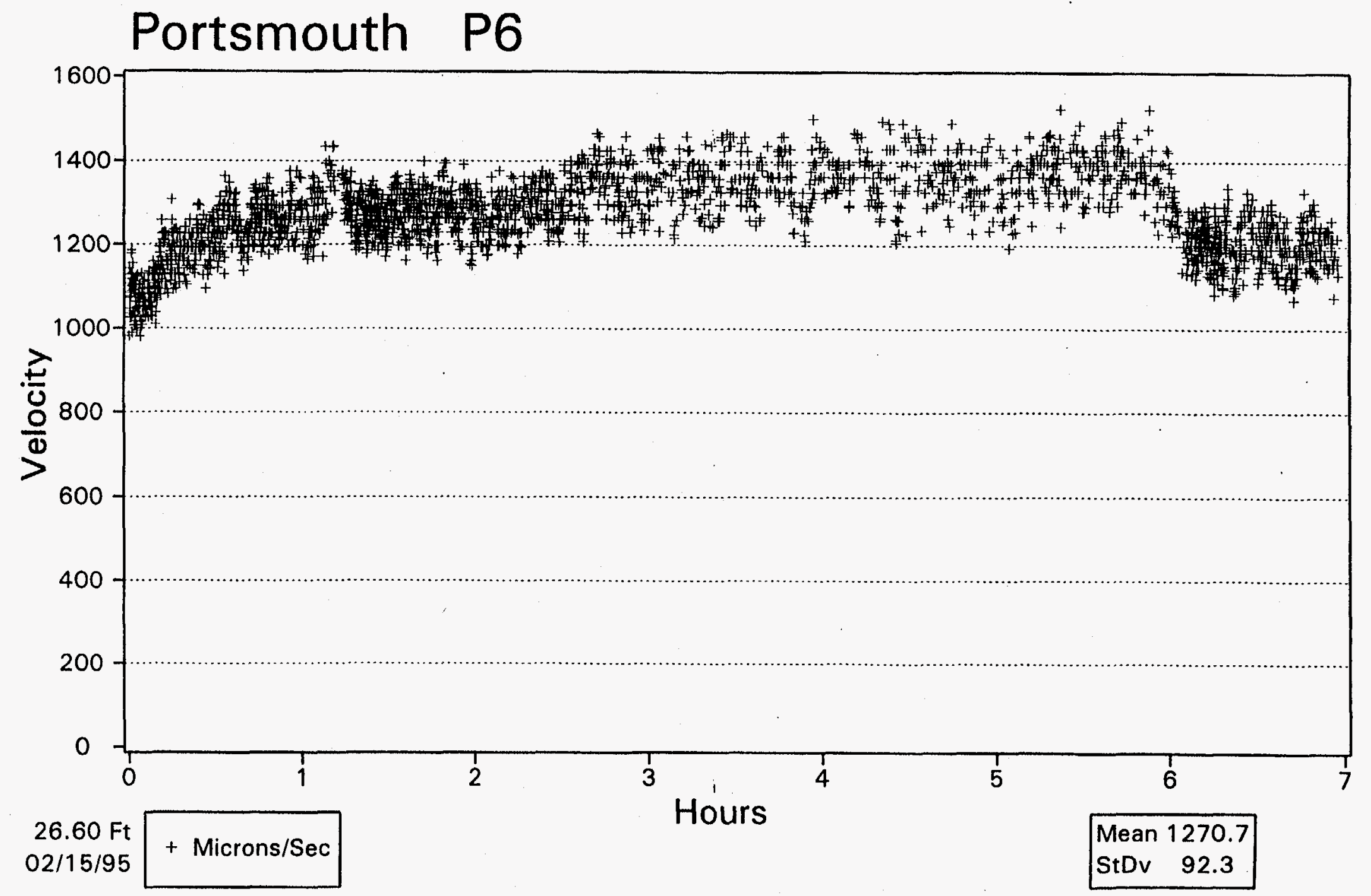




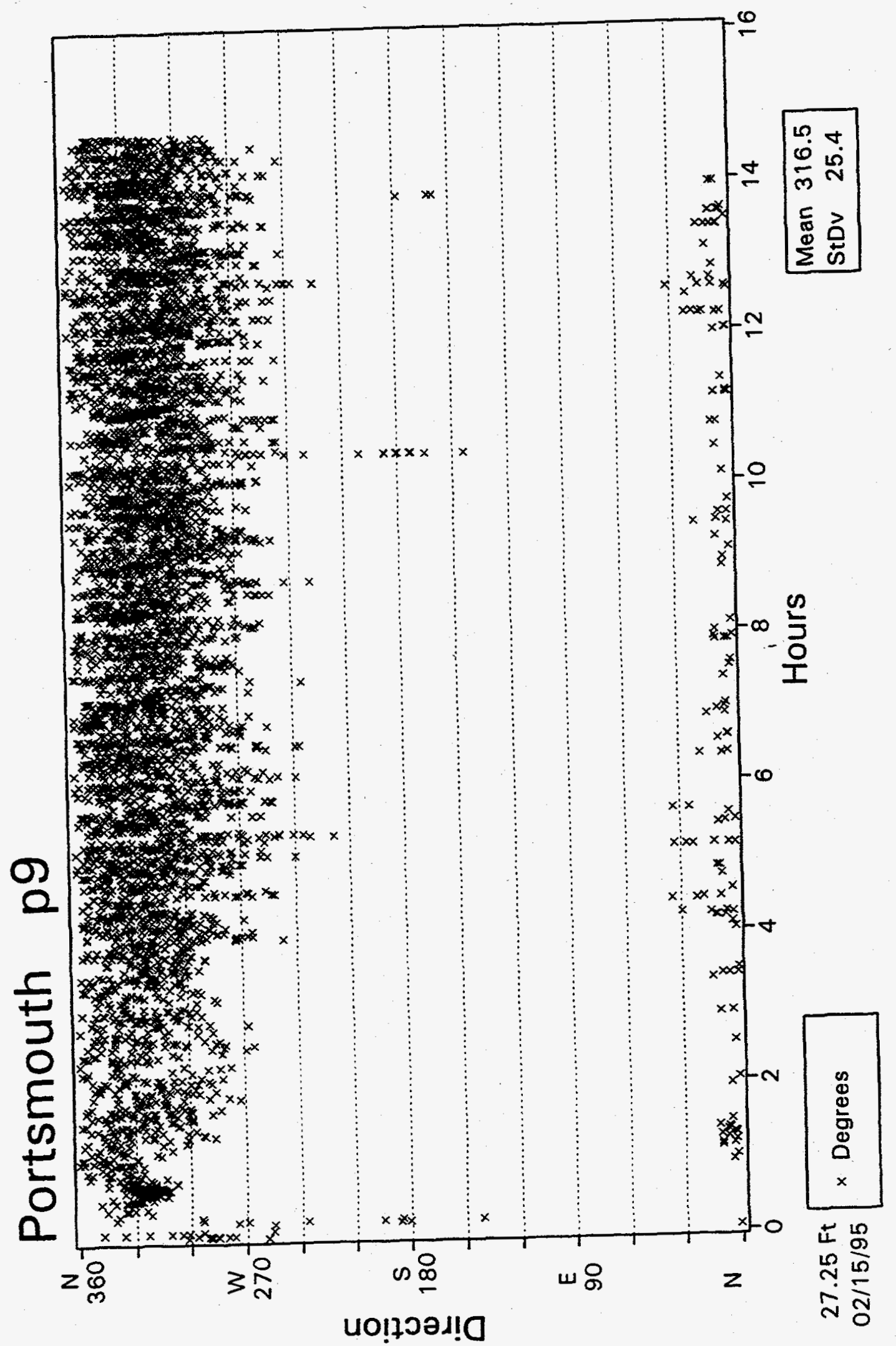




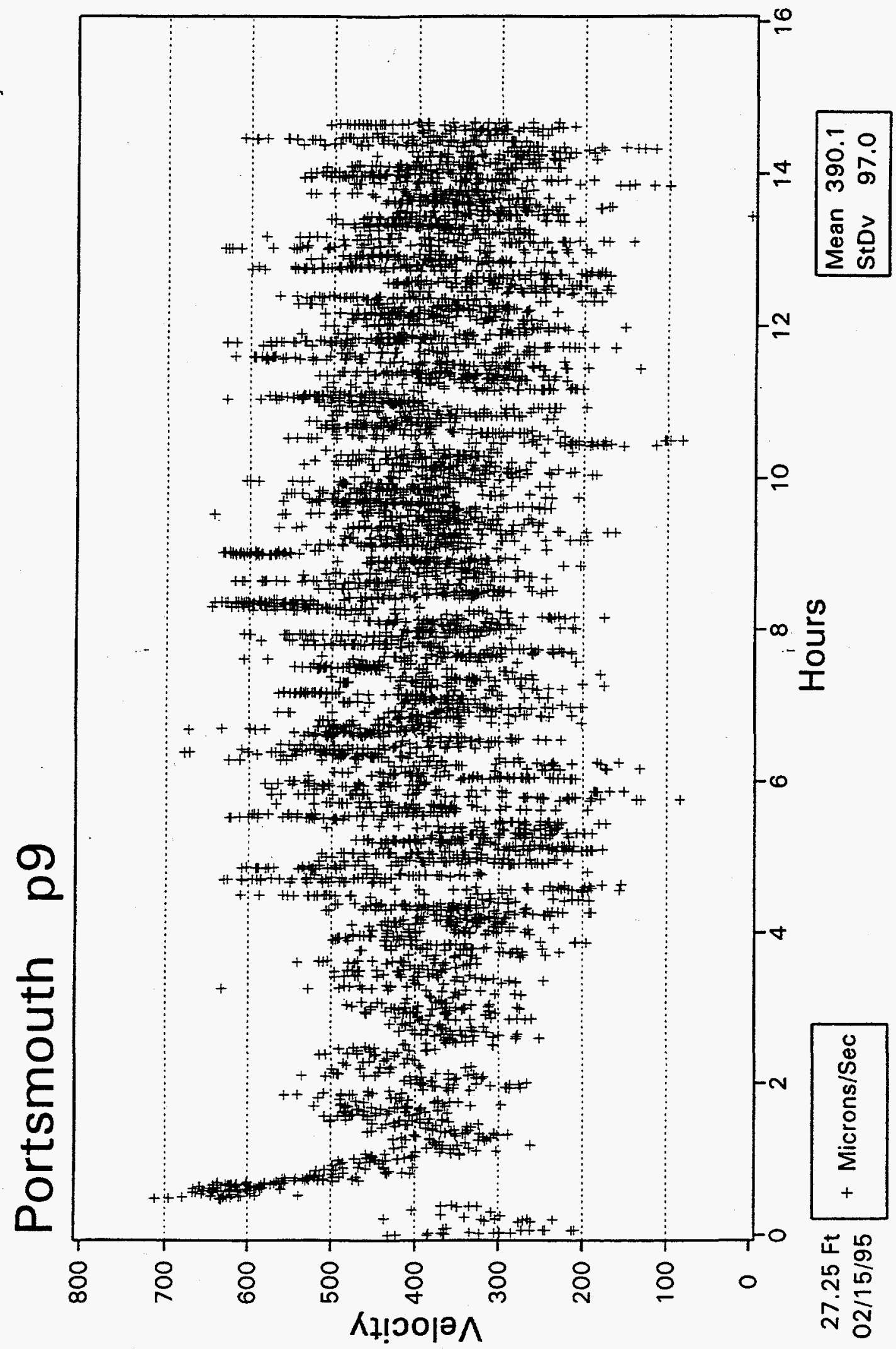




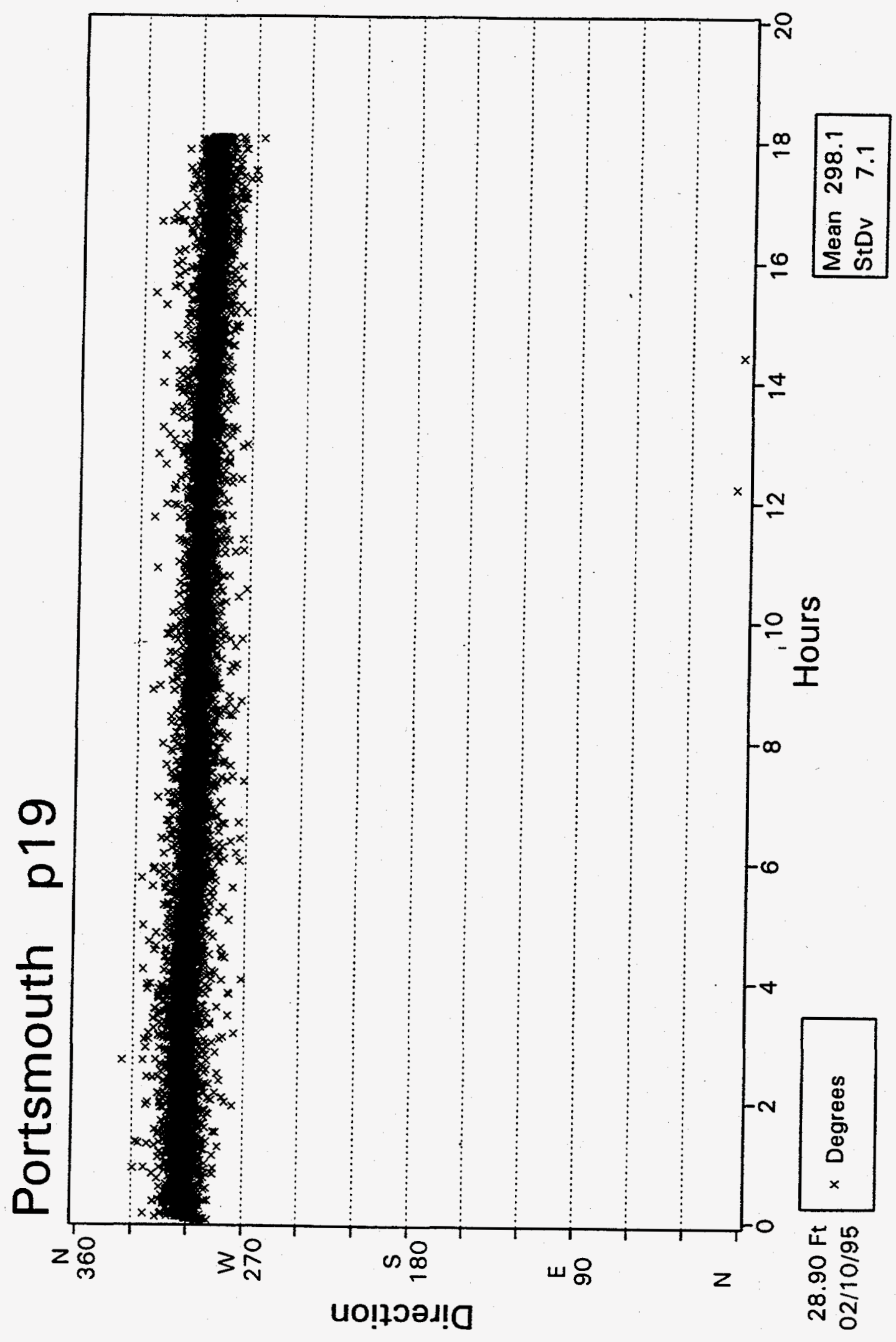




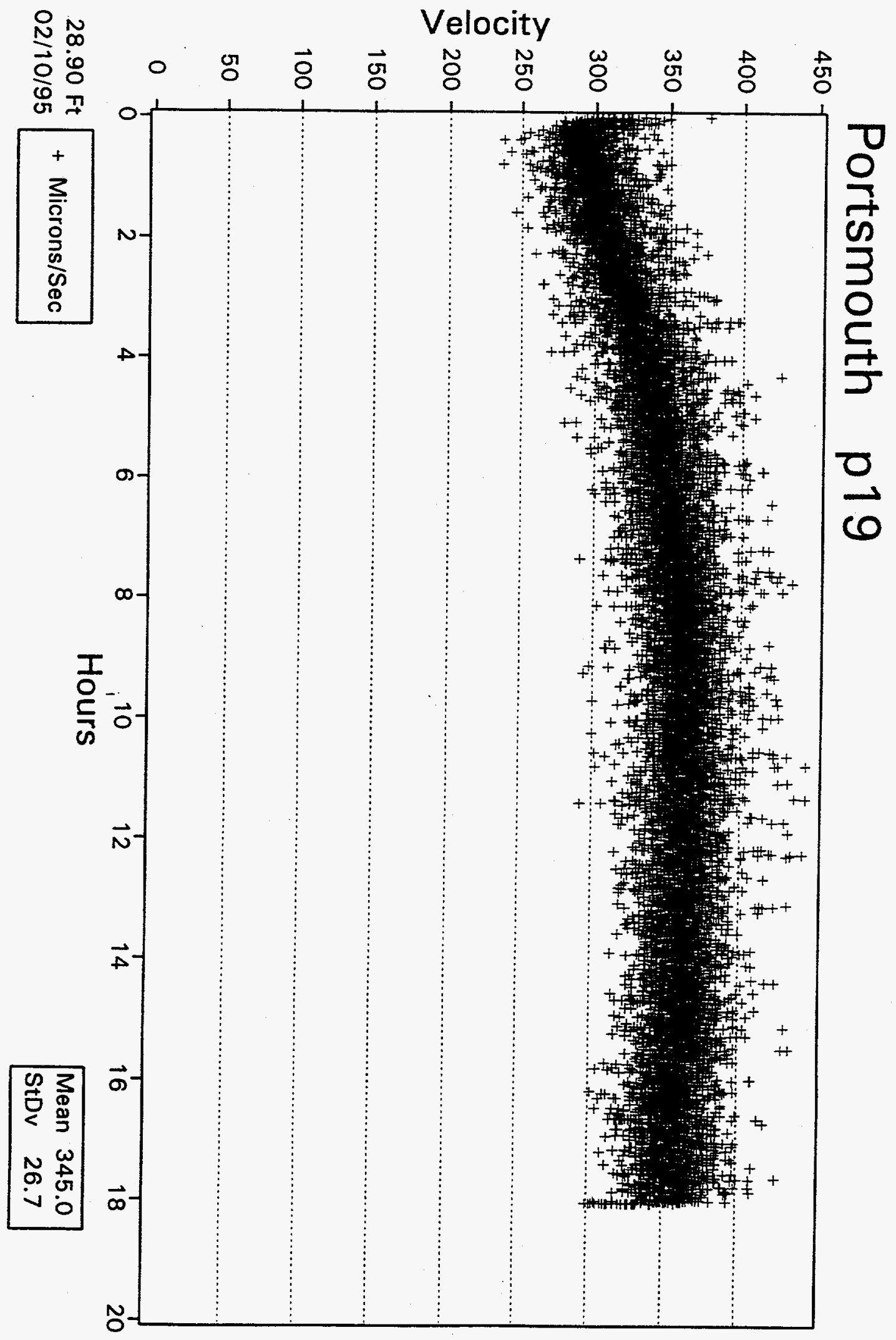




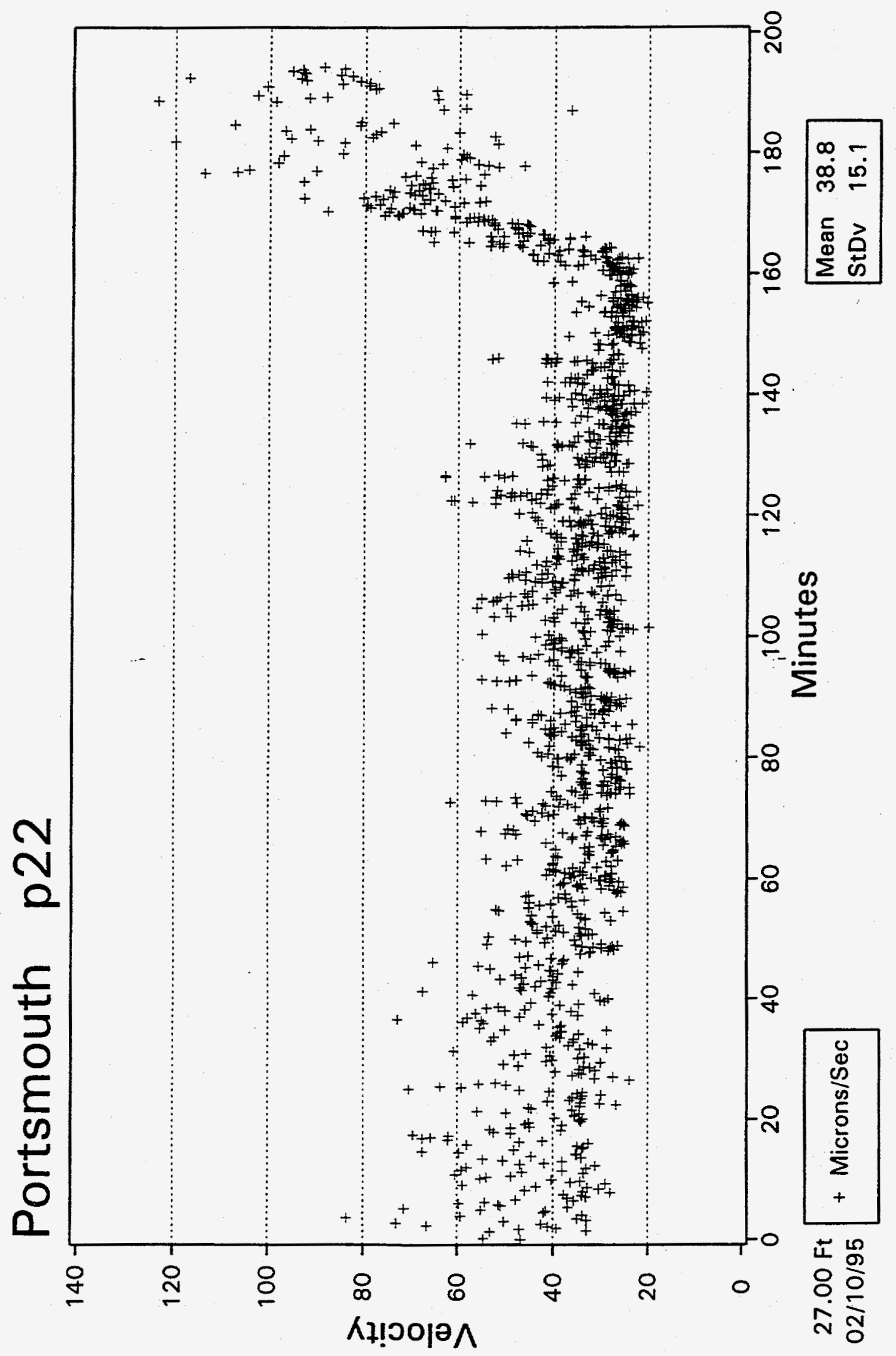




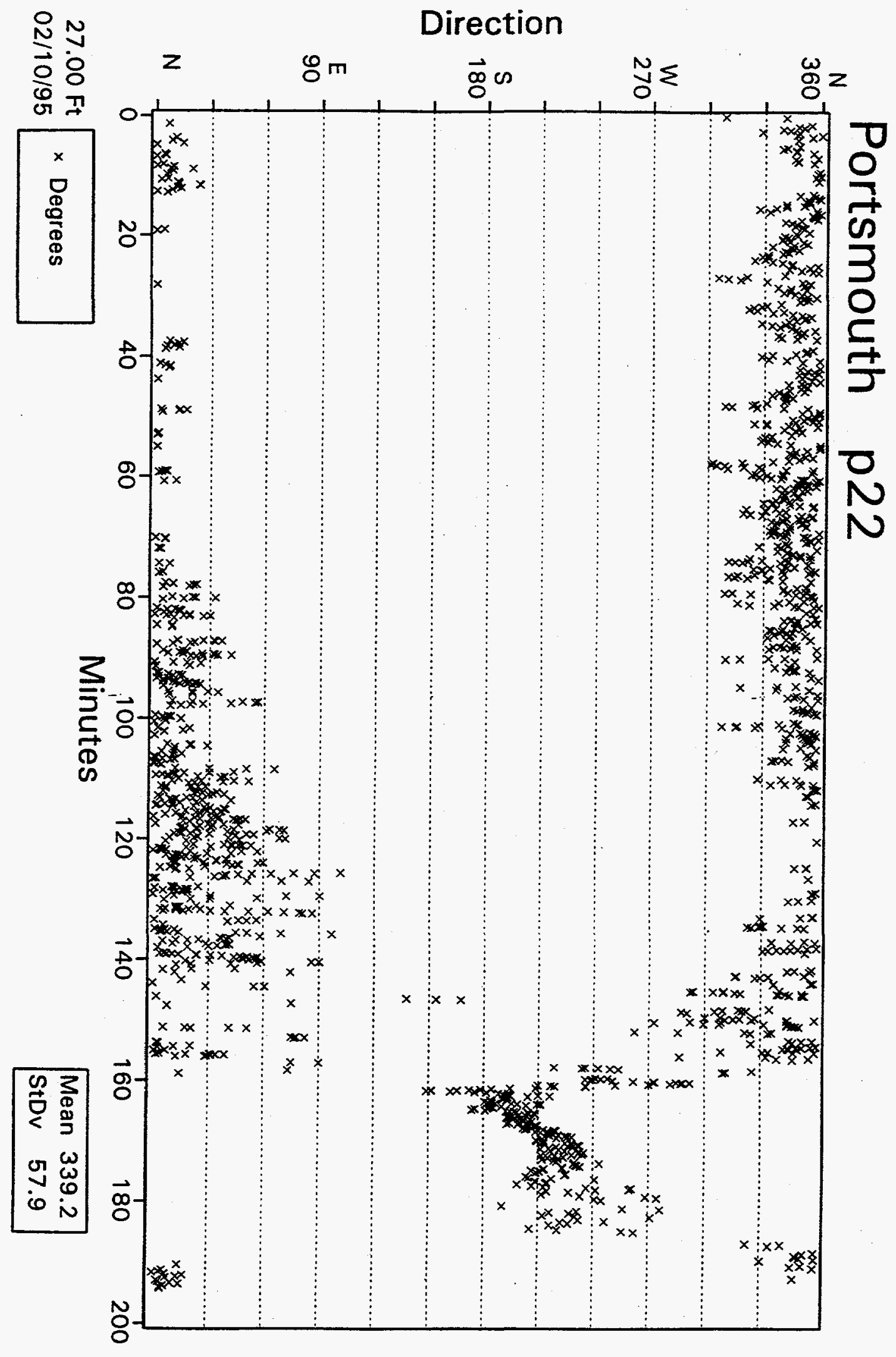




\section{INTERNAL DISTRIBUTION}

1. B. Berven

2. J. H. Cushman

3. T. Early

4. D. E. Fowler

5-9. D. Greene

10. B. Gu

11. S. G. Hildebrand

13. P. Kanciruk

14-18. P. Kearl

19. C. Kendrick

20-24. N. Korte

25. C. A. Little

26. J. M. Loar

27. R. Mann
28-32. M. Muck

33-35. M. Mumby

36. T. E. Myrick

37-39. D. Pickering

$40 . \quad$ D. E. Reichle,

41. C. Rightmire

42-44. R. Schlosser

45. D. S. Shriner

46-50. R. Siegrist

51. Central Research Library

52-54. ESD Library

55-56. Laboratory Records Dept.

57. Laboratory Records, ORNL-RC

\section{EXTERNAL DISTRIBUTION}

58. F. Anderson, Lockheed Martin Energy Systems, Portsmouth Gaseous Diffusion Plant, 3930 US Route 23 S, Piketon, OH 45661

59. J. Baker, Environmental Protection Specialist, AlliedSignal, Inc., 2000 E. 95th Street, Kansas City, MO 64131

60. M. Broido, Director, Environmental Sciences Division, ER-74, Department of Energy, 19901 Germantown Road, Germantown, MD 20874

61. G. Budzin, Lockheed Martin Energy Systems, Portsmouth Gaseous Diffusion Plant, 3930 US Route 23 S, Piketon, OH 45661

62. F. Bullock, Lockheed Martin Energy Systems, Portsmouth Gaseous Diffusion Plant, 3930 US Route 23 S, Piketon, OH 45661

63. S. Chamberlain, U.S. Department of Energy, 19901 Germantown Rd-CLOV, Germantown, MD 20874-1290

64. J. Clausen, Ogden Environmental \& Energy Services, 239 Littleton Road, Suite 1B, Westford, MA 01886

65. P. Cross, Lockheed Martin Energy Systems, Portsmouth Gaseous Diffusion Plant, 3930 US Route 23 S, Piketon, $\mathrm{OH} 45661$ 
66. E. G. Cumesty, ORNL Site Manager, Department of Energy, Oak Ridge National Laboratory, P.O. Box 2008, Oak Ridge, TN 37831-6269

67. D. Davenport, 4725 Sheboygan \#136, Madison WI 53705.

68. J. Douthitt, Lockheed Martin Energy Systems, Environmental Restoration and Waste Management, 761 Veterans Ave., Kevil, KY 42053

69. J. Harness, Program Manager, Environmental Technology Group, Department of Energy, Oak Ridge Operations, 55 Jefferson Street, Oak Ridge, TN 37831

70-74. T. Houk, Technology Applications Program Manager, Lockheed Martin Energy Systems, Portsmouth Gaseous Diffusion Plant, 3930 US Route 23 S, Piketon, OH 45661

75. L. Kantner, Department of Energy, Portsmouth Gaseous Diffusion Plant, 3930 US Route $23 \mathrm{~S}$, Piketon, $\mathrm{OH} 45661$

76. M. C. MacCracken, Director, Office of the U.S. Global Change Research Program, Code YS-1, 300 E Street, SW, Washington, DC 20546

77. R. Miller, Lockheed Martin Energy Systems, Environmental Restoration and Waste Management, 761 Veterans Ave., Kevil, KY 42053

78. C. Muhr, 2370 E. Road, Grand Junction, CO 81503

79. Office of Assistant Manager for Energy Research and Development, U.S. Department of Energy Oak Ridge Operations, P. O. Box 2001, Oak Ridge, TN 37831-8600

80-81. Office of Scientific and Technical Information, P. O. Box 62, Oak Ridge, TN 37831

82. A. Patrinos, Associate Director, Office of Health and Environmental Research, ER-70, Department of Energy, 19901 Germantown Road, Germantown, MD 20874

83. E. Phillips, U.S. Department of Energy, Oak Ridge Operations, 55 Jefferson Street, Oak Ridge, TN 37831.

84. J. Powers, U.S. Department of Energy, Portsmouth Gaseous Diffusion Plant, 3930 US Route 23 S, Piketon, OH 45661

85. J. Sheppard, Deputy Site Manager, Department of Energy, Portsmouth Gaseous Diffusion Plant, 3930 US Route 23 S, Piketon, OH 45661

HWCTS.DIS 
86. K. Palz, Schumacher Umwelt- und Trenntechnik GmbH, P.O. Box 1562, D-74555 Crailsheim, Germany

87. T. Foltz, Mears/HDD, Inc., 4500 North Mission, Rosebush, MI 48878

88. I. Sass, FlowTex, P.B. 1003 32, D-76275, Ettlingen, Germany

89. P. Seymour, Schumacher Filters America, Inc., P.O. Box 8040, Asheville, NC 28814 